\title{
WestVirginiaUniversity
}

THE RESEARCH REPOSITORY @ WVU

Graduate Theses, Dissertations, and Problem Reports

2013

\section{Margaret Ruthven Lang: Her life and piano works}

Juliana Yap

West Virginia University

Follow this and additional works at: https://researchrepository.wvu.edu/etd

\section{Recommended Citation}

Yap, Juliana, "Margaret Ruthven Lang: Her life and piano works" (2013). Graduate Theses, Dissertations, and Problem Reports. 439.

https://researchrepository.wvu.edu/etd/439

This Dissertation is protected by copyright and/or related rights. It has been brought to you by the The Research Repository @ WVU with permission from the rights-holder(s). You are free to use this Dissertation in any way that is permitted by the copyright and related rights legislation that applies to your use. For other uses you must obtain permission from the rights-holder(s) directly, unless additional rights are indicated by a Creative Commons license in the record and/ or on the work itself. This Dissertation has been accepted for inclusion in WVU Graduate Theses, Dissertations, and Problem Reports collection by an authorized administrator of The Research Repository @ WVU.

For more information, please contact researchrepository@mail.wvu.edu. 


\title{
MARGARET RUTHVEN LANG: HER LIFE AND PIANO WORKS
}

\author{
Juliana Yap
}

\author{
A Doctoral Research Project submitted to the \\ College of Creative Arts \\ at \\ West Virginia University \\ in partial fulfillment of the requirements for the degree of \\ Doctor of Musical Arts \\ in \\ Piano Performance
}
Peter Amstutz, D.M.A., Chair
Mary Ferer, Ph.D.
Keith Jackson, D.M.A.
Bruce Kang, Ph.D.

Lucy Mauro, D.M.A., Research advisor

School of Music

\section{Morgantown, West Virginia}

2013

Keywords: Margaret Ruthven Lang, American Piano Music, American Women Composers

Copyright 2013 Juliana Yap 


\section{ABSTRACT \\ MARGARET RUTHVEN LANG: HER LIFE AND PIANO WORKS \\ Juliana Yap}

American composer Margaret Ruthven Lang (1867-1972) is perhaps best known today for her songs and choral pieces and as the first woman composer to have a work performed by a major American orchestra. Though her chamber and orchestral works have not survived, her piano pieces provide an important look at this neglected composer's art. This research paper presents an overview of Lang's complete published piano works, eleven works in total ranging from elementary to advanced levels and dating from 1894 to 1919. It is designed as a reference for piano teachers, students and performers and provides pedagogical information, musical examples and contemporary critical reaction as well as biographical information. 


\section{Contents}

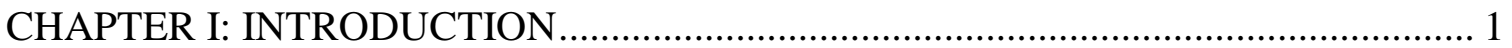

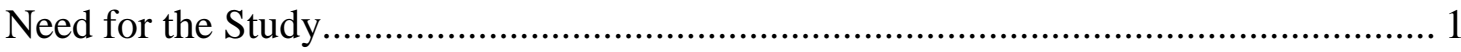

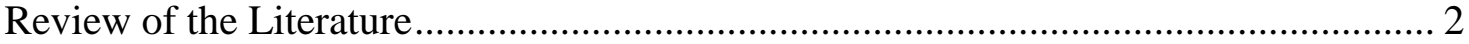

CHAPTER II: BIOGRAPHY OF MARGARET RUTHVEN LANG .......................... 6

CHAPTER III: AN INTRODUCTION TO THE PIANO WORKS ….......................... 17

CHAPTER IV: LANG'S FIRST PIANO COMPOSITIONS .......................................... 20

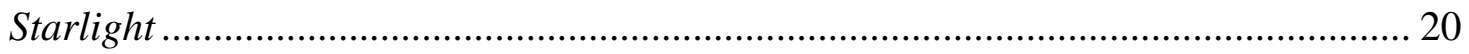

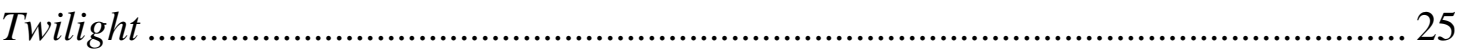

CHAPTER V: PETIT ROMAN EN SIX CHAPITRES, OP. 18 ..................................... 29

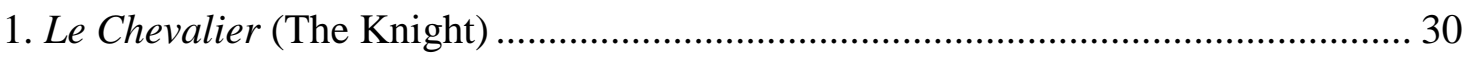

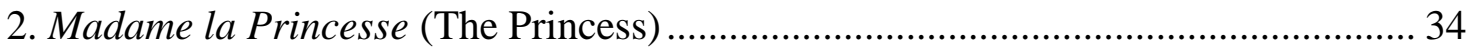

3. Bal chez Madame la Princesse (Ball at the Home of the Princess) ........................ 39

4. Monsieur le Prince (The Prince) ........................................................................... 46

5. L'Épée de Monsieur le Prince (The Prince's Sword) ............................................. 50

6. La mort du Chevalier (The Death of the Knight)................................................. 54

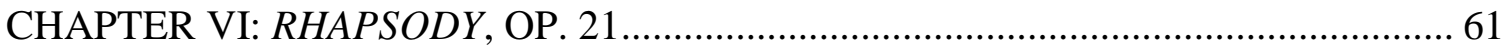

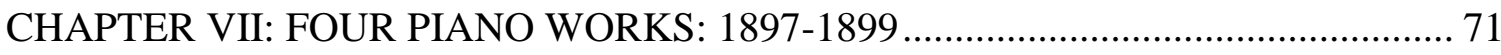

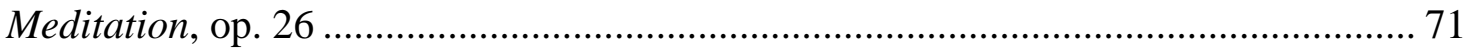

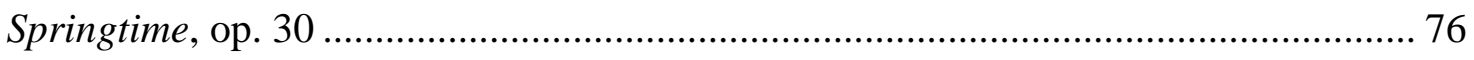

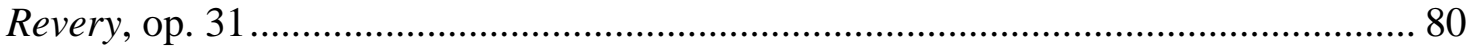

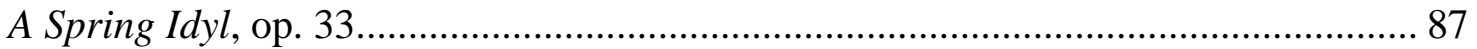




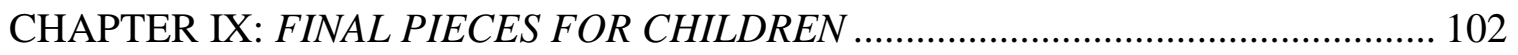

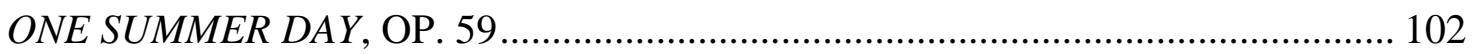

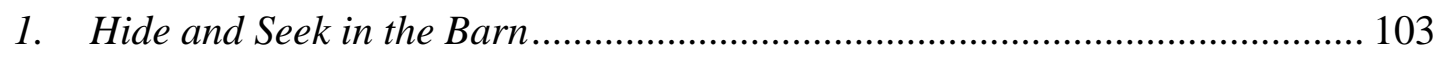

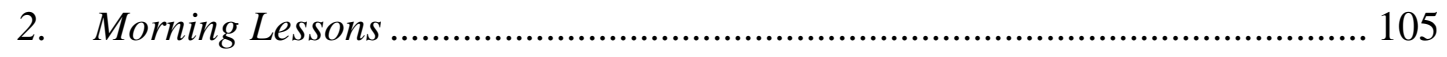

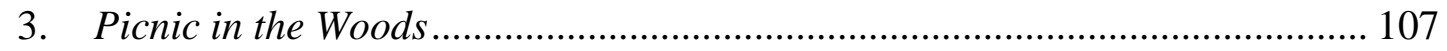

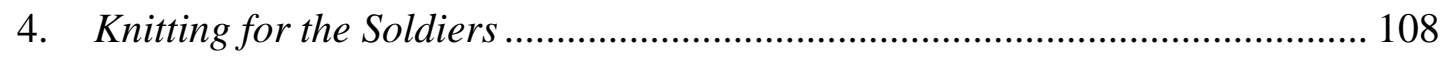

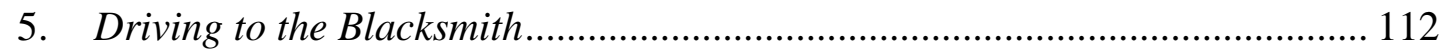

THREE PIECES FOR YOUNG PLAYERS, OP. 60 ............................................ 115

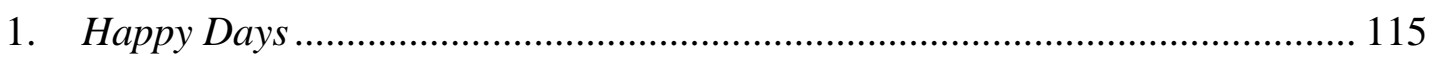

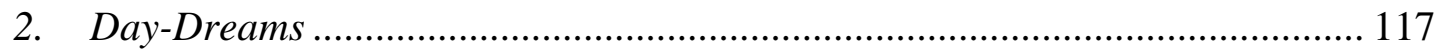

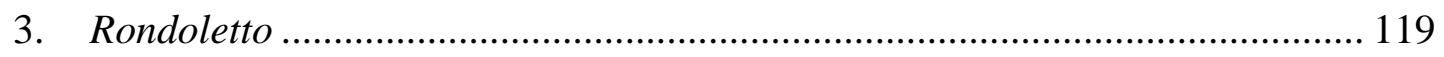

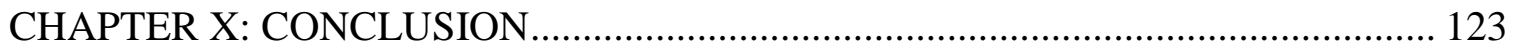

APPENDIX: CHRONOLOGICAL LISTS OF PIANO WORKS .............................. 125

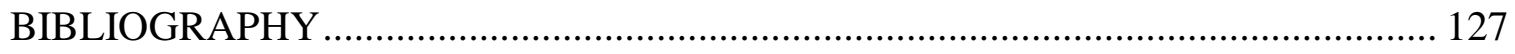




\section{CHAPTER I}

\section{INTRODUCTION}

The abundance of repertoire available for pianists is at once a gift and a curse: a vast amount of music to be explored or performed but a greater likelihood for works to go out of fashion and to be forgotten. Such is the case with the works of Margaret Ruthven Lang, one of the preeminent American female composers of her time. Her collection of piano music is a treasure that has become buried and awaits rediscovery.

This research paper, "Margaret Ruthven Lang: Her Life and Piano Works," provides a reference to assist the pianist in learning, teaching, and performing the important treasure of Lang's piano compositions. It is an attempt to rediscover and re-establish Lang's prominent position as a composer; present her outstanding collection of piano works; and document a missing gap in the history of American piano music. The scope of this research includes each of Lang's eleven published piano works, ranging from elementary to advanced pieces, and features aspects of study for pedagogical and performance purposes. Also included is biographical information on Lang, thus helping pianists gain both an understanding of Margaret Lang's life and the piano music of this significant yet neglected composer.

\section{Need for the Study}

Margaret Lang was an important contributor to American music. During a time in history when females were expected to stay at home and far away from the professional world, Lang made valuable strides towards improving the image of women composers starting when she was twenty-six years old:

The event that places Lang most prominently in the history of 
American music took place when Lang's orchestral work, Dramatic Overture, Op. 12, no. 2, was premiered by the Boston Symphony Orchestra under the baton of Arthur Nikisch. This performance marked the first time a major American Symphony orchestra had programmed and performed an orchestral work by a women composer. ${ }^{1}$

Lang's compositions in the genres of overture and song were incredible accomplishments for an America woman in the late 1800s and early 1900s. Her overtures (and other symphonic works) were performed by orchestras in Baltimore, New York and Chicago, and earning royalties into the 1950s she published some 130 songs, which were performed internationally by some of the most esteemed singers of the day, including Ernestine Schumann-Heink, Dan Beddoe, Alma Gluck, Mary Garden, and Richard Crooks. The unspoken beauty of Lang's compositional output, can be found in her piano music. This research is the first comprehensive study of Lang's piano music and provides an important resource for this body of American piano music. It not only provides additional insight into Lang as a significant but neglected composer, but also presents a better understanding of American piano music at a time when the image of the women composer began to emerge.

\section{$\underline{\text { Review of the Literature }}$}

Margaret Ruthven Lang's compositions have been catalogued and reviewed by several scholars. Some authors (e.g., Judith Ann Cline, Laurie Katharine Blunsom, and Rupert Hughes) have provided annotated lists of Lang's works. Moreover, these and other scholars either focused on her life and her songs or her works for orchestra and choir. A review of the literature related to Lang reveals that relatively few studies deal

\footnotetext{
${ }^{1}$ Judith Ann Cline, "Margaret Ruthven Lang." in Women Composers: Music Through the Ages, 7, edited by Sylvia Glickman and Martha Furman Schleifer. (New York: G. K. Hall, 2003), 530.
} 
with the piano works, and none in any complete form. The scholarly studies reviewed included books, dissertations, and articles.

Judith Cline's 1998 dissertation, "Margaret Ruthven Lang: Her Life and Songs,"2 is divided into ten chapters. The first two chapters consist of introductory material and a biography of Lang, followed by seven chapters of analysis and discussion of a comprehensive selection of Lang's songs. An Appendix includes a catalog of Lang's complete known works. Although this study discusses Margaret Ruthven Lang's life and lists her complete works, it focuses only on her songs.

Laurie Katharine Blunsom’s dissertation, “Gender, Genre, and Professionalism,” explores the issues that affected the careers of five American women composers from 1880 to 1925 , through the lens of the genre with which they were most preoccupied, their songs.3 These five women composers are Clara Rogers, Helen Hopekirk, Amy Beach, Margaret Lang and Mabel Daniels. In the first part of her dissertation, Blunsom examines the social and musical roles for late 19th-century American women. Later on, she discusses how these composers attempt to solve problems associated with their professional careers, including collegiality, institutional support, and community recognition. In the second part, Blunsom explains that popular songs provided musical connections to the social and professional worlds, including those embodied in publishing, marketing, and performing venues. She closes her research by examining the songs. Overall, Blunsom's research demonstrates the integral role songs played in the careers of these five women.

\footnotetext{
${ }^{2}$ Judith Ann Cline, "Margaret Ruthven Lang: Her Life and Songs" (D.M.A. diss., University of Miami, 1993).

${ }^{3}$ Laurie Katharine Blunsom, "Gender, Genre and Professionalism: The Songs of Clara Rogers, Helen Hopekirk, Amy Beach, Margaret Lang and Mabel Daniels, 1880-1925” (D.M.A. diss., Brandeis University, 1999).
} 
Edwin Ninyon Chaloner Barnes, the author of American Women in Creative Music, provides a full list of biographical references that can be found in the appendix.4 Barnes believed in the equality of men and women, and through this work shows his concern for the woman composer. One of these female composers is Margaret Ruthven Lang, whom Barnes cites as a distinguished composer:

She excels in her songs which are supremely womanly, yet withal of great strength. Of her orchestral offerings, three overtures are outstanding ... Miss Lang has done some excellent choruses and anthems, and over one hundred songs.5

In From Convent to Concert Hall: A Guide to Women Composers, Sylvia

Glickman and Martha Furman Schleifer explore Lang's orchestral works, songs, and choral pieces that were featured regularly by the Boston Symphony Orchestra, the Apollo Club, and the Cecilia Society. Glickman and Schleifer write that "it was in Boston that Lang was most performed and admired."6

Rupert Hughes, a notable American historian, film director and composer, wrote Contemporary American Composers in 1900 and dedicated the fifth chapter to two women composers, Amy Beach and Margaret Lang. ${ }^{7}$ Hughes comments on the quality of Lang's songs:

In a few instances it seems to me that the best things done by women equal the best things done by men in those lines. In music I place two or three of Miss Lang's small songs among the chief of their manner. ${ }^{8}$

Hughes covers all genres of Lang's work: concert overtures, cantatas, arias with

\footnotetext{
${ }^{4}$ Edwin Ninyon Chaloner Barnes, American Women in Creative Music (Washington D.C.: Music Education Publications, 1936), 10.

${ }^{5}$ Barnes, American, 10.

${ }^{6}$ Sylvia Glickman and Martha Furman Schleifer, From Convent to Concert Hall: A Guide to Women Composer (Westport, CT: Greenwood Publishing Group, Inc., 2003), 184.

${ }^{7}$ Rupert Hughes, Contemporary American Composers. (Boston: L.C. Page and Co., 1900), 424438.

${ }^{8}$ Hughes, Contemporary, 425.
} 
orchestral accompaniment, a Rhapsody for the piano, a work for male chorus with an accompaniment for two pianos, songs, and other works.

Christine Ammer highlights Lang's career in her book Unsung: A History of Women in American Music. ${ }^{9}$ Ammer briefly describes Lang's musical background and her entrée into Boston's musical world. Ammer lists chronologically Lang's best works that were performed by major groups in Boston, New York, and Chicago and includes what the critics said of each performance. Later, she describes Lang's outstanding compositional characteristics such as her treatment of harmonies and her exploration of dissonance. Amner says:

Unlike Beach, however who was accused, often justly, of overcomplicating her works with unnecessary key changes and chromaticism, Lang's harmonies have as Rupert Hughes put it, 'the appearance of spontaneous work. ${ }^{10}$

The listed works mainly focus on Lang's compositions for orchestra, choir, voice, and small chamber groups.

${ }^{9}$ Christine Ammer, "The First 'Lady Composers"' in Unsung: A History of Women in American Music (Portland, OR: Amadeus Press, 2001), 105-107.

${ }^{10}$ Hughes, Contemporary, 434. 


\section{CHAPTER II}

\section{BIOGRAPHY OF MARGARET RUTHVEN LANG}

Margaret Ruthven Lang (November 27, 1867 - May 29, 1972) was groomed at an early age to become one of the most prolific and accomplished women composers in the United States. Her mother, Francis Morse Burrage Lang, was an amateur singer and her father, Benjamin Johnson Lang, was an internationally known pianist and musical entrepreneur in Boston. Lang's childhood musical environment has been noted to be one of the most stimulating aspects of her artistic growth. James Johnston, a Lang family historian, writes:

When a child of twelve, Miss Lang used to play ensemble with two friends who came in for this delightful phase of musical work. It occurred to her to write something for this group, so she launched forth her craft. She humorously relates how her father helped her to "paw out" the consecutive fifths and other startling intruders in well-ordered composition. But he wisely saw that her thought was of more value than its expression, a far seeing vision which belongs to what is termed the "new education." But which, new or old, is truth. So the study of musical form was at once enjoined. The steady diet of harmony and counterpoint was fairly loathed by this young girl who, however, daily walked into her Sahara, believing that she would gain a certain facility by this exercise. ${ }^{11}$

Lang's early piano instruction was with a student of her father. Later, he took over her instruction. Her non-musical education was at private schools. ${ }^{12}$ Her studies in composition and piano with her father began at the age of twelve and continued for seven years. Lang biographer Judith Ann Cline writes, "B. J. Lang was a demanding, yet devoted teacher, believing that technique was the basis for excellence in music, and Margaret Lang held much respect for her father's teaching and continued to seek his

\footnotetext{
${ }^{11}$ James Johnston, Margaret Ruthven Lang \& Family, "Margaret Ruthven Lang 1867-1972" http://www.margaretruthvenlang.com (accessed January 29, 2013).

${ }^{12}$ César Saerchinger, International Who's Who in Music and Musical Gazetteer. (New York: Current Literature Publishing Company, 1918), 356.
} 
advice after her career was well-established. ${ }^{13}$ In addition to composition and piano lessons, she studied violin with Louis Schmidt in Boston.

It is easier to understand the development of Lang's career by first examining the pre-eminent career of her father, Benjamin Johnson Lang (December 28, 1837- April 3 1909). He was a conductor, pianist, organist, teacher, and composer who made his public musical debut at the age of twelve, playing Chopin's Ballade in A-flat, op. 47, in 1849. At the age of eighteen, he left his church organist position and embarked upon a threeyear tour of study and concertizing in Berlin and elsewhere. He studied mainly under Alfred Jaëll, but also had some instruction from Franz Liszt (1811-1886). It is during this time that he began his lasting friendship with Liszt and his daughter, Cosima (1837-1930), who happened to be four days older than he. In an interview in 1967 conducted by Margo Miller, a writer for the Boston Globe, Margaret recalled, "One evening, at the whist table, [a favorite card game of Liszt] B. J. held all the trumps, and when suspected of being a card shark, found a supporter in Liszt." ${ }^{\text {,14 }}$ B. J. Lang was also a pall bearer in Liszt's funeral procession. The Boston singer and composer Clara Kathleen Rogers (1844-1931) described the event during her trip to Bayreuth in 1886:

... from our windows, we watched a long and impressive funeral procession, in which we recognized many distinguished musicians-each one having a lighted torch though it was broad daylight. One of the first in the procession to be recognized by us was our fellow Bostonian, B. J. Lang, who was one of the pall bearers, and who, like the rest, was bearing his torch with due solemnity. ${ }^{15}$

\footnotetext{
${ }^{13}$ Cline, "Margaret Ruthven Lang: Her Life and Songs," 11.

${ }^{14}$ Donald George and Lucy Mauro, "Margaret Ruthven Lang (1867-1972) and Her German Roots in the Wagnerian Circle," Die Tonkunst 2 (2012): 213.

${ }^{15}$ Clara Kathleen Rogers, The Story of Two Lives: Home, Friends and Travels, (Massachusetts: Plimpton Press, 1932), 166.
} 
In 1871, Lang visited Richard Wagner (who was now married to Cosima), at Tribschen and Bayreuth and offered assistance in publicizing the Bayreuth Festival in America. "Cosima Wagner recalled the first meeting of B. J. Lang and his wife when they visited the Wagners, noting that their four girls were presented to the Langs. She recorded that she enjoyed speaking English, but that Richard regarded it not a serious language, but only a dialect." ${ }^{16}$ In 1967, Margaret recalled in an interview, "We lived in Munich ...we knew the Wagners very well. They used to send Isolde under Mother's wing to go to concerts. Isolde would go very faint listening to Liszt and we had to take her out of the concert. That made me very mad!"17

Lang's importance as a performer and musical entrepreneur in Boston is indisputable. He introduced a large amount of music, including many of Wagner's works, to America, conducting premieres and performing as an orchestral soloist. B. J. Lang conducted the premiere of the famous Tchaikovsky Piano Concerto No. 1 with Hans von Bülow performing, and later he would perform the piano part himself. He also conducted the American premiere of the concert version of Wagner's Parsifal. B. J. Lang was also the founder of two important choral societies still in existence today, the Apollo Club and the Cecilia Society (known now as the Boston Cecilia).

Lang's compositions included an oratorio David, organ pieces, piano pieces, songs, and sacred and secular choral pieces including the Swedish folksong arrangement $\mathrm{Hi}$ - $\mathrm{F}$-Lin-Ke-Le, which Lang prepared for the Apollo Club. The choral parts to this were published-making it the only piece by Lang himself that was printed, the choral parts are at the Boston Public Library ${ }^{18}$

\footnotetext{
${ }^{16}$ Cosima Wagner, Diaries, ed. by Martin Gregor-Dellin and Dietrich Mack, trans. by Geoffrey Skelton, Volume I - 1869-1877, (New York: Harcourt Brace Jovanovich, 1978), 394.

${ }^{17}$ Margo Miller, "Oldest Boston Symphony Orchestra Subscriber Recalls Gentle World of the Past-Life With Liszt and the Wagners," Boston Globe, February 19, 1967, p. A-27.

${ }^{18}$ James Johnston, Margaret Ruthven Lang \& Family, "Composer" http://www.margaretruthvenlang.com (accessed January 29, 2013).
} 
However, the only published material of his appeared in a work by Chadwick, who used a "melodic motive" of Lang's in the first of his "Drei Walzer für das Pianoforte." Lang destroyed all of his other manuscripts. ${ }^{19}$ In 1903 , Yale University conferred on him the degree of Master of Arts. He also received an Honorary Degree from Harvard in 1908.

As an active and well-respected musician in Boston, B. J. Lang's was frequently visited at his home by many musicians, both local and foreign. "Margaret grew up in this metropolitan household and knew Dvořák and Paderewski as guests." ${ }^{20}$ According to Laurie Katherine Blunsom, "When Lang's father held a reception for Dvořák, Margaret Lang stayed upstairs until all guests had gone, and then she came down to show Dvorrák her compositions." ${ }^{21}$ Also, "she was accustomed to traveling abroad with her parents, [and made] her first trip to Europe at the age of two. As a child, she visited the home of Richard Wagner and knew the Wagner children as playmates." 22 As she grew older, she was aware of her musical surroundings and listened with eager interest to the music performed at evening gatherings at Wagner's house. "These soirees, involving musicians of the magnitude of Liszt, Wagner, Von Bülow, Dvořák and Paderewski, certainly contributed to Margaret Lang's sense of sophistication regarding the work of composition.",23

\footnotetext{
${ }^{19}$ James Johnston, "Margaret Ruthven Lang \& Family: Benjamin Johnson Lang 1837-1909" http://www.margaretruthvenlang.com (accessed January 29, 2013).

${ }^{20}$ Donald George and Lucy Mauro, "Retreat from Fame: Margaret Ruthven Lang, the once famous Boston composer, rediscovered." The Bulletin of the Society For American Music 37 (2011): 33-4.

${ }^{21}$ Blunsom, "Gender, Genre and Professionalism: The Songs of Clara Rogers, Helen Hopekirk, Amy Beach, Margaret Lang and Mabel Daniels, 1880-1925," 56

${ }^{22}$ Lang Family Papers, scrapbooks; Lang Family Papers, Boston Public Library, as quoted in Cline.

${ }^{23}$ Cline, "Margaret Ruthven Lang: Her Life and Songs," 11.
} 
Following in her father's footsteps, Margaret Lang, at age nineteen, had the opportunity to study abroad. She spent two seasons (1885-87) with her mother and siblings in Munich, where she studied violin with Franz Drechsler, composition with Ludwig Abel, and counterpoint and fugue with Victor Gluth, a professor at the Royal Conservatory in Munich. Cline writes, "There is no indication that Lang enrolled herself at the Royal Conservatory and indeed, it is doubtful that she was, since women were not allowed to study counterpoint at the school until 1898."24

Upon her return from abroad, Lang continued her composition and orchestration study with George Chadwick, who at that time was a professor at the New England Conservatory and later become its president. She was a serious pupil; she interviewed members of the Boston Symphony to discuss the possibilities of their instruments. ${ }^{25}$ She undertook large instrumental forms as well as shorter solo piano works, chamber music, art songs, and choral pieces. In these early years, she felt it necessary to find a space where she could focus on composing uninterrupted. Supported by her father, she rented a room in the neighborhood. In this place, she kept all her manuscripts. She was immensely critical of her own work and did not hesitate to discard pieces deemed to be not of good quality, a practice she may have learned from her father.

Lang's career began after her return from abroad in 1887. The first public performance of her songs was given at the second of two song recitals sung by William J. Winch and accompanied by B. J. Lang in Boston's Chickering Hall on December 14, 1887. A review in the Boston Home Journal described her as a "highly promising song composer," and went on to say:

\footnotetext{
${ }^{24}$ Cline, "Margaret Ruthven Lang: Her Life and Songs," 19.

${ }^{25}$ Juliette A. Graves Adams, "Musical Creative Work Among Women," Music (1896), 265-72.
} 
Miss Lang writes for the voice as though she thoroughly understood its requirements and she sympathetically responds thereto with an abundance of talent and originality, not to mention the piquancy and refined quaintness that in the present instance she has shown, in her treatment of words, and with all the musical feeling of a genuine tone poet. ${ }^{26}$

The Saturday evening edition of The Boston Gazette ended its review by saying, "The young composer is to be complimented sincerely on the excellence of her works and congratulated on the immediate appreciation that attended them and the deserved success they achieved. ${ }^{27}$ A review in The Brookline Chronicle was highly complementary: “The group of German songs, by Margaret Ruthven Lang was exquisite, not only in their lyrical beauty, but in the unison between the sentiment of the words and that of the music. ${ }^{28}$ Subsequent reviews were consistently positive. This was a most promising start to her compositional career.

Over the next few years, Lang enjoyed frequent national and international performances of her songs. At a concert during the Paris Exhibition on July 12, 1889, Lang's song, "Ojalá,” was performed. Edward MacDowell, who was the accompanist, wrote to Lang on July 10, 1889, saying,

I showed your songs to Van der Stucken (the organizer of the concert) who says he will put Ojalá on his program. I expect to accompany it myself and hope it will bring down the house. ${ }^{29}$

A review of the concert mentioned that Lang's composition was one of "the most interesting and original compositions in the program... "Ojalá"("God willing" in Arabic,

\footnotetext{
${ }^{26}$ Cline, "Margaret Ruthven Lang: Her Life and Songs," 13.

${ }^{27}$ Johnston, "Margaret Ruthven Lang \& Family: Childhood and Early Career" http://www.margaretruthvenlang.com (accessed January 29. 2013).

${ }^{28}$ Johnston, "Margaret Ruthven Lang \& Family: Childhood and Early Career" http://www.margaretruthvenlang.com (accessed January 29. 2013).

${ }^{29}$ Cline, "Margaret Ruthven Lang: Her Life and Songs," 21.

${ }^{30}$ Lang Family Paper. Boston Public Library, as quoted in Cline.
} 
Spanish, and Hebrew) was also part of the inauguration concert for the Lincoln Concert Hall in Washington, D.C., on March 26, 1890.

Indeed, 1889 was the beginning of Lang's blossoming career; not only were her songs performed, but also they were chosen for publication by Arthur P. Schmidt of Boston. Schmidt was the promoter and publisher of many other female composers of the time, including Clara Kathleen Rogers, Helen Hopekirk, and Amy Marcy Cheney Beach. Today, the Library of Congress in Washington, D.C. has preserved Lang's published works along with numerous correspondences in the Schmidt archives.

A prestigious event that gave Lang a spot in the history of American music took place in 1893 when her orchestral work, Dramatic Overture, op. 12, was given its premiere by the Boston Symphony Orchestra under the baton of Arthur Nikisch. This performance marked the first time a major American symphony orchestra had performed an orchestral work by a woman composer. At that time, Lang, who was twenty-six years old, "crept into the balcony and hid" when her work was performed, according to a 1967 article. ${ }^{31}$ In the same year, Lang's orchestral overture, Witichis, op. 10, was chosen for performance by the Chicago Orchestra at the World's Columbian Exhibition in Chicago conducted by Theodore Thomas. She was one of twenty-one American composers who submitted their works. Later, it was performed three times in the summer of 1893 with Max Bendix, who had been recruited by Theodore Thomas to be the concertmaster and the conductor of the new Chicago Orchestra. ${ }^{32}$

\footnotetext{
${ }^{31}$ Miller, Boston Globe, February 19, 1967, p. A-27.

${ }^{32}$ Johnston, "Margaret Ruthven Lang \& Family: People and Places" http://www.margaretruthvenlang.com (accessed January 29. 2013).
} 
Lang composed additional orchestral works, such as the overture, Totila, op. 23, Three Dramatic Scenes for solo voice and orchestra, and Sappho's Prayer to Aphrodite for alto and orchestra, which was performed in 1896 in New York. In addition, she wrote Phoebus's Denunciation of the Furies at His Delphian Shrine for baritone and orchestra, and Armida, op. 24, for soprano and orchestra, which was performed in January 12, 1896, by the Boston Symphony Orchestra under the direction of Emil Pauer. Her final orchestral composition was Ballade in D, op. 36, which was performed by the Baltimore Symphony in a "Women in Music Grand Concert" of $1901 .{ }^{33}$ Unfortunately, there were no published editions of these works and the manuscripts have not been found. "In 1919, Lang stopped composing and began to destroy all her orchestral works and many of her other pieces. She said she used to "clean house" every ten years and get rid of things she deemed "unimportant" (when you live to be 104, that's a lot of cleaning). ${ }^{34}$

In spite of her success in orchestral works, Lang was best known for her songs, choral works, and piano pieces. A. P. Schmidt published Lang's first piano works in 1894; in the same year Lang had two piano compositions published in Half Hours with the Great Composers, a collection of piano etudes, character pieces, and transcriptions. This collection included such prominent American composers as Edward MacDowell, George Whitefield Chadwick, Horatio Parker, Arthur William Foote, and Clara Kathleen Rogers. Lang's most productive creative period was from 1893 through 1907, during which her seventy songs, seven solo piano works, and five choral compositions were published. After her father's death in 1909, her output became sparse, with fallow periods

\footnotetext{
${ }^{33}$ Cline, "Margaret Ruthven Lang: Her Life and Songs," 16.

${ }^{34}$ Donald George and Lucy Mauro, "Margaret Ruthven Lang: On the 40th Anniversary of Her Death,"http://hampsongfoundation.org/margaret-ruthven-lang-on-the-40th-anniversary-of-herdeath/ (accessed February 12, 2013).
} 
of two to three years in between compositions. Lang's last composition was Three Pianoforte Pieces for Young Players, op. 60, published in 1919 by Theodore Presser.

Lang's sudden withdrawal from the musical world at the age of fifty has raised many questions. She turned to religion and started writing inspirational tracts titled "Messages from God," which are included in the Lang Family Papers, kept in the Boston Public Library. Six thousand copies of these small booklets were printed and sent out at her own expense; Lang spent her earnings from her music sales to do so. According to members of her family, Lang also frequently included a small "sermon" in her correspondence.

In addition to her religious calling, Lang's decision to withdraw from music may have been due to her family obligations. After B. J. Lang died in 1909, Margaret, the eldest child in the family, felt the necessity of taking care of her mother and managing the family home. She left the workspace that she rented in the neighborhood. She noted, "All dates and days have been alike since my mother's pneumonia; it is only today that she is mending and I can look about me and pick up some of the threads." ${ }^{35}$ This was a letter written from Lang to her long-time friend, Mabel Wheeler Daniels. Daniels's letters are at the Schlesinger Library at Radcliffe Institute. "When asked in 1967 why she stopped composing, Lang's answer was: 'Why did I stop, I had nothing to say." ${ }^{36}$ Lang also once said:

My music writing stopped soon after The Heavenly Noel's many performances in many places, with orchestra; with piano; and once at the

\footnotetext{
${ }^{35}$ Cline, Women Composers: Music Through the Ages, 530.

${ }^{36}$ John J. Mullins, "Composer Margaret Lang, 101, just 'wants to live forever."” Boston Globe, 19 February 1967, as quoted in Johnston.
} 
request, with organ, piano, and harp; - for the much-involved housekeeping took place during my mother's last housebound years. ${ }^{37}$

Although Lang was no longer active in the musical world, the Musical Portrait Series in Etude listed her in 1935-36. Also, Lang was cited in editions of American Women - The Official Who's Who Among the Women of the Nation in 1939-1940. Cline writes, "These publications marked the last printed references to Margaret Ruthven Lang as a professional composer during her lifetime."38

Later in her life, Lang passed the time by attending concerts, reading, writing letters, and receiving visitors. Lang wrote to her great-nephew that she was corresponding with up to seventy people in three languages. In 1955, Lang wrote to her long-time friend, Marian MacDowell: "I am glad, very glad not to be active in any musical way, but only a thankful listener." ${ }^{39}$ Indeed, she was a devoted listener, most especially to the Boston Symphony Orchestra. She was the longest subscriber in the symphony's history and held a season ticket for ninety-one consecutive years. In her honor, the orchestra placed a small plaque on the seat she occupied regularly, B-1 of the first balcony. Lang said, "The woman next to me wants my seat. We chaff about it. But I want to keep the name Lang on the subscriber's list." 40

Like a typical Bostonian, Lang used to travel by subway to Symphony Hall. To celebrate her 100th birthday on November 24, 1967, Erich Leinsdorf conducted the Orchestra in the "Old Hundredth Chorale" and "Sheep May Safely Graze" from Bach's

\footnotetext{
${ }^{37}$ Margaret Ruthven Lang. Diary, Sept. 29, 1892, Lang Family Papers, Boston Public Library, as quoted in Blunsom.

${ }^{38}$ Cline, "Margaret Ruthven Lang: Her Life and Songs," 19.

${ }^{39}$ Johnston, "Margaret Ruthven Lang \& Family: 1867-1972"

http://www.margaretruthvenlang.com (accessed January 29. 2013).

${ }^{40}$ Miller, Boston Globe, February 19, 1967, p. A-27.
} 
Cantata BWV 208. After the concert, Lang declined a ride from Henry B. Cabot and a reception given by the President of the Orchestra's Board of Trustees, preferring to leave early at the reception honoring her to catch the last train home. Margo Miller described Lang in The Boston Globe at this time as being "tiny and chipper as a semi-quaver (sixteenth note) and dressed in black with a knotted rope of pearls and rings her adornments, she sat in the long bay window of her Brimmer St. apartment." ${ }^{, 41}$

After her $100^{\text {th }}$ birthday, those in charge of her affairs insisted she should have a live-in companion. One friend remembered Lang in her later years, "walking rapidly toward the Charles Street station (she had to climb six medium flights of stairs from street to train platform). ${ }^{, 42}$ Lang remained in good health until shortly before her death on May 29, 1972, six months before she would have celebrated her $105^{\text {th }}$ birthday. From careful observation, her scrapbooks reveal her pride in the reviews, articles, and programs that showcase her groundbreaking accomplishments, especially as an American woman composer. Her sincerity as a person was reflected in her compositions, as Rupert Hughes said in Contemporary American Composers in 1900, when he stated,

Personally, I see in Miss Lang's compositions such a depth of psychology that I place the general quality of her work above that of any other woman composer...; it is so sincere, so true to the underlying thought, that it seems to me to have an unusual chance of interesting attention and stirring emotions increasingly with the years. ${ }^{43}$

\footnotetext{
${ }^{41}$ Miller, Boston Globe, February 19, 1967, p. A-27.

${ }^{42}$ Miller, Boston Globe, February 19, 1967, p. A-27.

${ }^{43}$ Hughes, Contemporary, 438.
} 


\section{CHAPTER III}

\section{AN INTRODUCTION TO THE PIANO WORKS}

In addition to her successful compositions for voice and for orchestra, Lang's idiomatic writing for piano made the solo piano piece an integral part of her creative output. The catalogue of her published works for solo piano is small (she left eight single compositions and three collections of pieces). These pieces form a small portion of her creative output during her active years (1894-1919); however, they represent a significant expressive outlet for Lang. The entire gamut of moods typical of the character piece is encompassed. Some are lyrical, others are soulful, or joyful, and a few are dramatic. As she said of her works for piano,

My intentions have been poetic and never purely (i.e. merely) musical, often dramatic and sometimes story-telling. I disapprove of pianoforte or vocal music which has no definite meaning to convey. I believe that pianoforte music would paint a picture, tell a story or speak to the heart. The musical setting of a song should be subservient to its text, according with the poetical color of the text. ${ }^{44}$

Margaret Lang's piano music draws on the tradition of the $19^{\text {th }}$ century, with an emphasis on the character piece. All her piano pieces bear descriptive titles, except Rhapsody, op. 21 and Rondoletto, op. 60, no. 3. She used descriptive musical motifs throughout her compositions, such as the descending pattern of Starlight or the Chopininspired chromatic melodic figures in the "Waltz" from Bal chez Madame la Princesse to suggest an overall picture or feeling. In addition, Lang was a voracious reader, according

\footnotetext{
${ }^{44}$ William Smythe Babcock Mathews, The Great in Music: A Systematic Course of Study in the Music of Classical and Modern Composers, 1 (Chicago: Music Magazine Publishing Company, 1900), 277-79.
} 
to her family, and had developed enthusiasm for religious and philosophical subjects.

Compositional ideas that emerged from her reading are evident from the inspiration and actual inclusion of poetry by Victor Hugo, John Banister Tabb, Lizette Woodworth Reese, and John Vance Cheney in some of her piano works.

Margaret Lang's keyboard writing shows that she was a gifted composer and pianist. Lang is at her very best in the expressive, short character pieces in which a story is expressed. Structures are typically kept simple, binary or ternary in form, often with a coda. Her solo pieces cover the full range of the keyboard. Her tempo indications and metronome markings are in accordance with the musical content. In her piano works, Lang's attention to detail is superb (articulation, dynamics, tempo changes and pedal markings), her shaping of phrases is sensible, her harmonic language is ingeniously colorful, ever fresh-sounding, and her ability to capture the essence of expression is inspiring. She is able to fit all these characteristics into overall traditional forms.

It is hard to pinpoint the characteristics of Lang's musical style which contains a mixture of the traditional and the experimental, and true to her beliefs, captures the essence of her inspiration, be it an American or French poem or her own imaginative story. This combination of a variety of elements has led to more than one approach in attempting to capture its quintessence. Laurie Blunsom in her dissertation, entitled, “Gender, Genre, and Professionalism” writes,

Margaret Lang's style in general is grounded in late nineteenth-century German musical language, with rich harmonies, dense textures and complex chromaticism...However, she is also eclectic: at various points she utilized features of various styles, including impressionism, orientalism and folk tunes....Chromaticism, dominant 13ths and augmented 6ths are prevalent, especially in ....art songs. ${ }^{45}$

\footnotetext{
${ }^{45}$ Donald George and Lucy Mauro, "Margaret Ruthven Lang (1867-1972) and her German Roots in the Wagnerian Circle." Die Tonkunst 2 (2012): 216.
} 
In Lang's music, one can identify elements of Baroque style, Impressionism, American and English folk music, Oriental music, and even some American popularsong harmonies. Other features of Lang's style of writing for the piano include thick textures and attention to inner voices to the extent that frequently several layers exist simultaneously. Her piano writing demonstrates a carefully crafted symbiosis between technical demands and musical content.

The fact that all of Lang's piano music was published during her lifetime has resulted in chronological accuracy in the sequence of opus numbers, except for Twilight and Starlight, which do not have opus numbers. Both of these works were published in 1894 by J. B. Millet in Boston. In the same year, the Arthur P. Schmidt Company, which published many of Lang's songs, published her first piano collection, Petit Roman en six chapitres. Her last composition, Three Pieces for Young Players, op. 60, was published by Theodore Presser in 1919. Although she stopped composing at the age of fifty-two in 1919, sales receipts on file at the Library of Congress from Lang's publisher, A. P. Schmidt, show that her works were sold not only in the United States, but also in the United Kingdom. Her last two sets of pieces, One Summer Day, op. 59, and Three Pieces for Young Players, can be found in the British Public Library. ${ }^{46}$

Following is a detailed discussion of each of Lang's piano works presented in order of composition.

${ }^{46}$ Cline, Women Composers: Music Through the Ages, 531. 


\section{CHAPTER IV}

\section{LANG'S FIRST PIANO COMPOSITIONS}

\section{Starlight}

Starlight is one of the two first piano pieces published in Half Hours with the Best Composers, part 10, in 1894 by J. B. Millet along with works by other American composers, such as Edward MacDowell (1860-1908), George Whitefield Chadwick (1854-1931), Horatio Parker (1863-1919), Arthur Foote (1853-1937), and Clara Kathleen Rogers (1844-1931). The Half Hours series contains piano études, character pieces, and transcriptions. ${ }^{47}$

Starlight is in ternary (A-B-A') form. It shows Lang's clever descriptive writing with the use of colorful harmonies, quiet dynamics, and the descending, sparkling figure in the right hand in different high registers of the piano representing the Starlight. The first section shows a rapid succession of alternating third and sixth figures in the right hand, showing the influence of Frédéric Chopin, in particular, his Etude op. 10, no. 7 (example 4.1.1).

Example 4.1.1 Frédéric Chopin: Etude, op. 10, no. 7, mm. 1-2

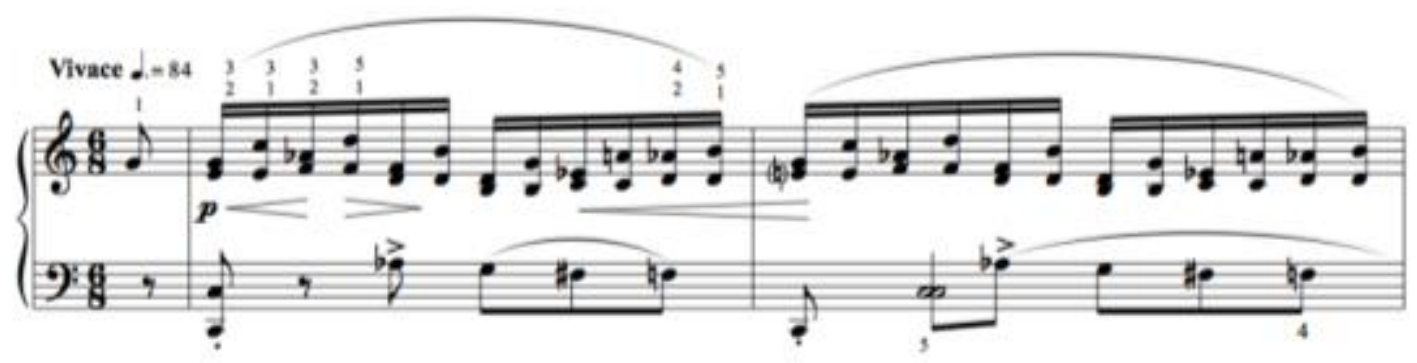

${ }^{47}$ Cline, Women Composers: Music Through the Ages, 533. 
In order to portray the Starlight, Lang utilizes sixths and thirds in a descending line, the opposite of Chopin's approach. Meanwhile, the two-note slurred figure in the left hand repeats steadily yet creates a carefree swing, confirmed by the sixteenth notes in the right hand (example 4.1.2). This barcarolle or swinging two-note slur reflects the tempo and expression markings at the beginning of the piece, Allegretto and con grazia.

Example 4.1.2 Margaret Ruthven Lang: Starlight, mm.1-17
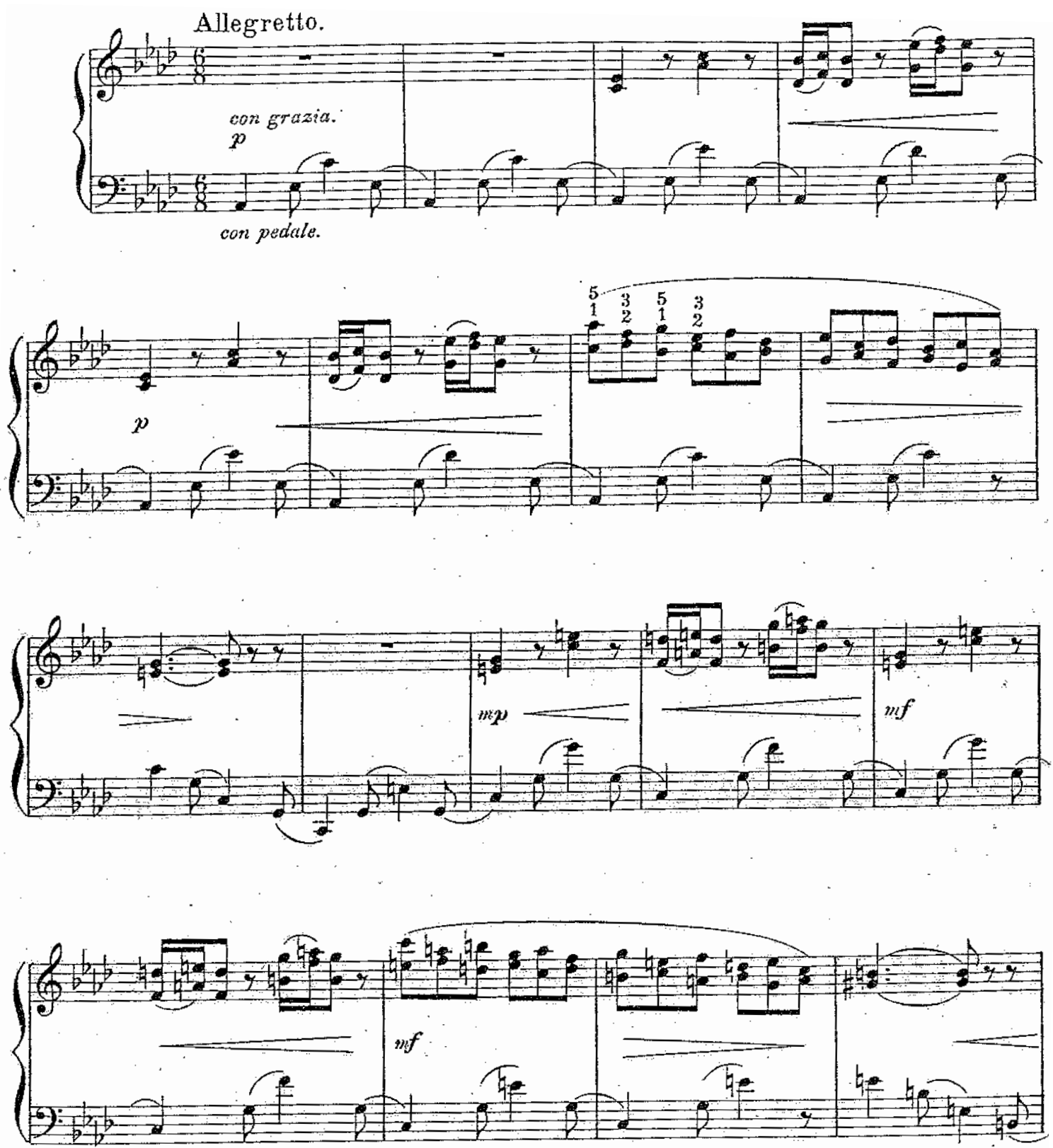
The marking con pedale starts in the first measure and lasts for four pages. Careful listening to the melodic and harmonic pedaling is the key to producing the crystal-clear, light-like effect. Lang writes the specific pedal marking only for the last two lines of the piece, perhaps to heighten the shimmering Starlight effect (example 4.1.3) and for the performer to carefully observe the silence with the rests.

Example 4.1.3 Margaret Ruthven Lang: Starlight, mm. 113-122
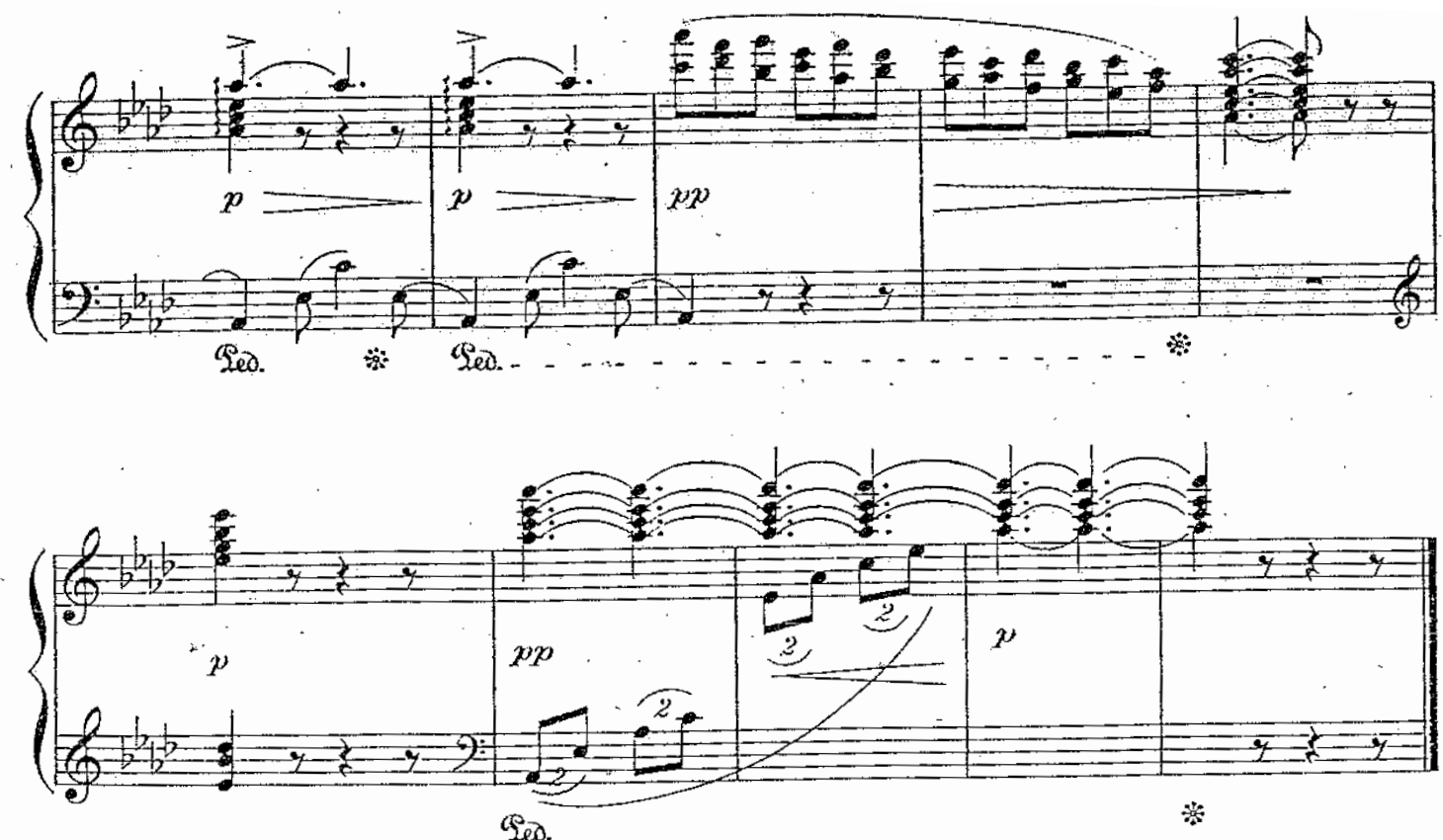

This piece works well as an etude for late intermediate and early advanced pianists. The phrasing and sound present special challenges for the advanced pianist, and the two-note slur in the left hand, inspired by the barcarolle rhythm, is particularly challenging to achieve the motivic subtleties. Lang uses meter and key changes for the middle section (example 4.1.4). 
Example 4.1.4 Margaret Ruthven Lang: Starlight, mm. 35-44
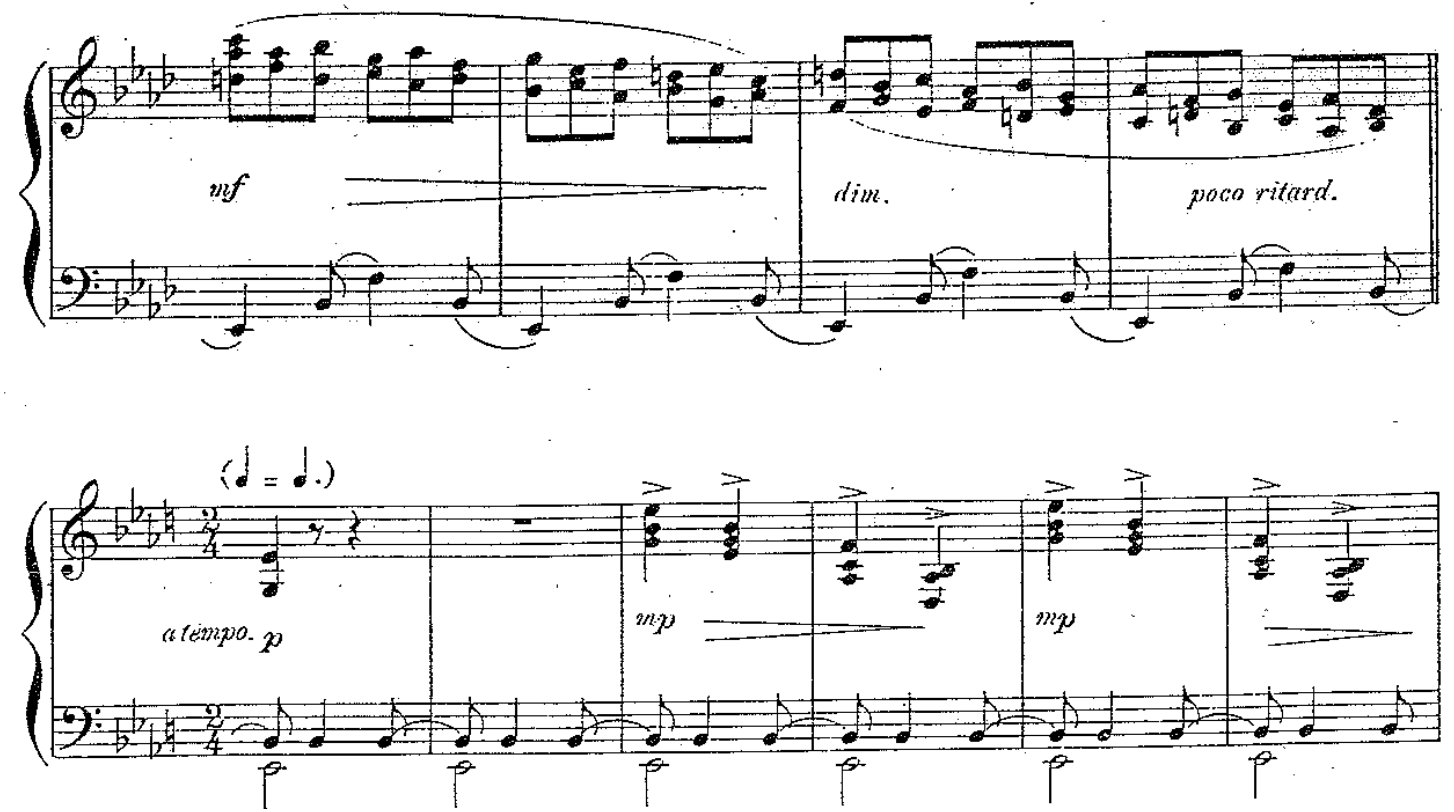

Lang represents the sparkling stars with the crystalline top voice melody, found here in a higher register than in the A section (example 4.1.5).

Example 4.1.5 Margaret Ruthven Lang: Starlight, mm. 45-66
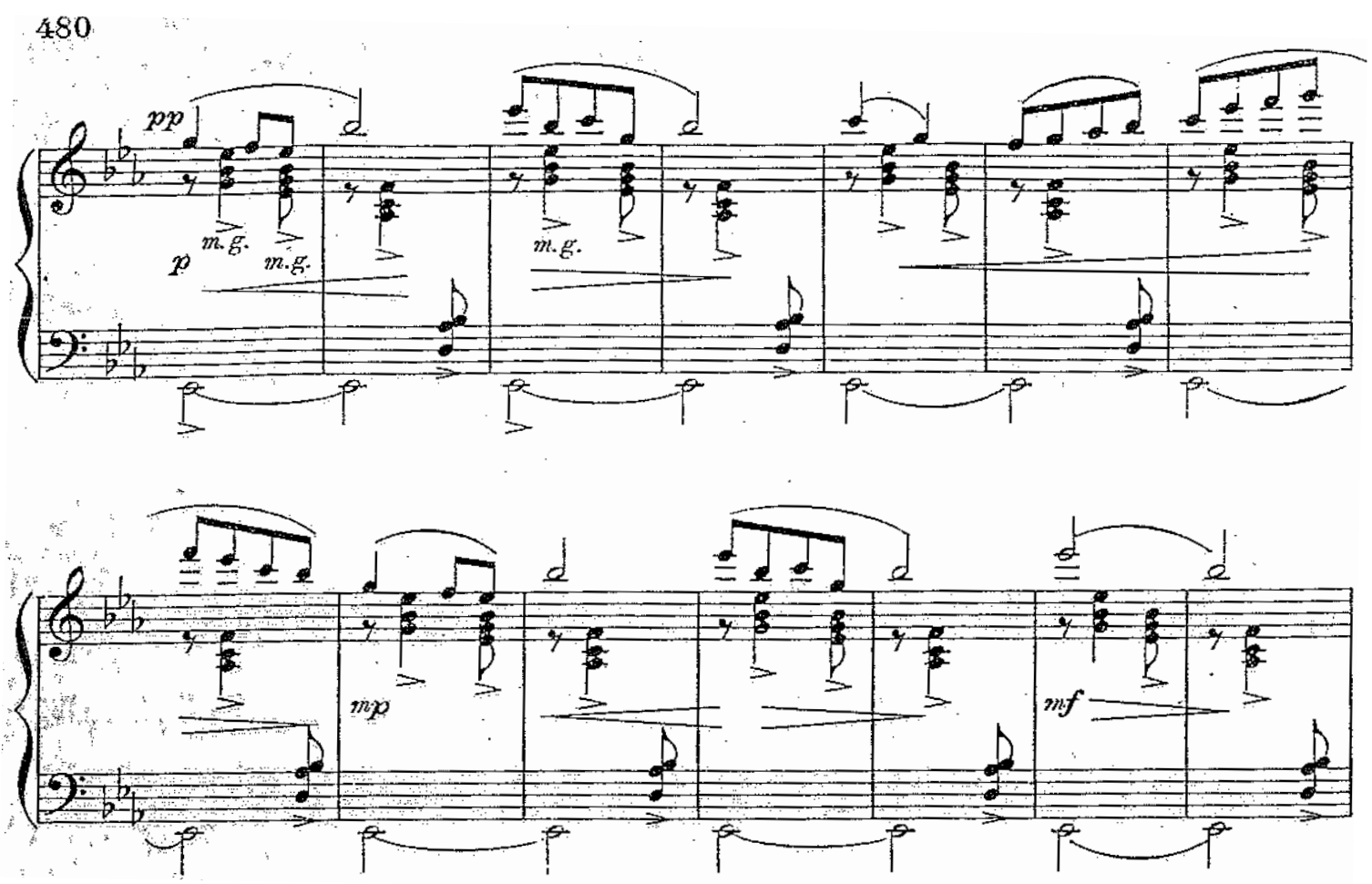


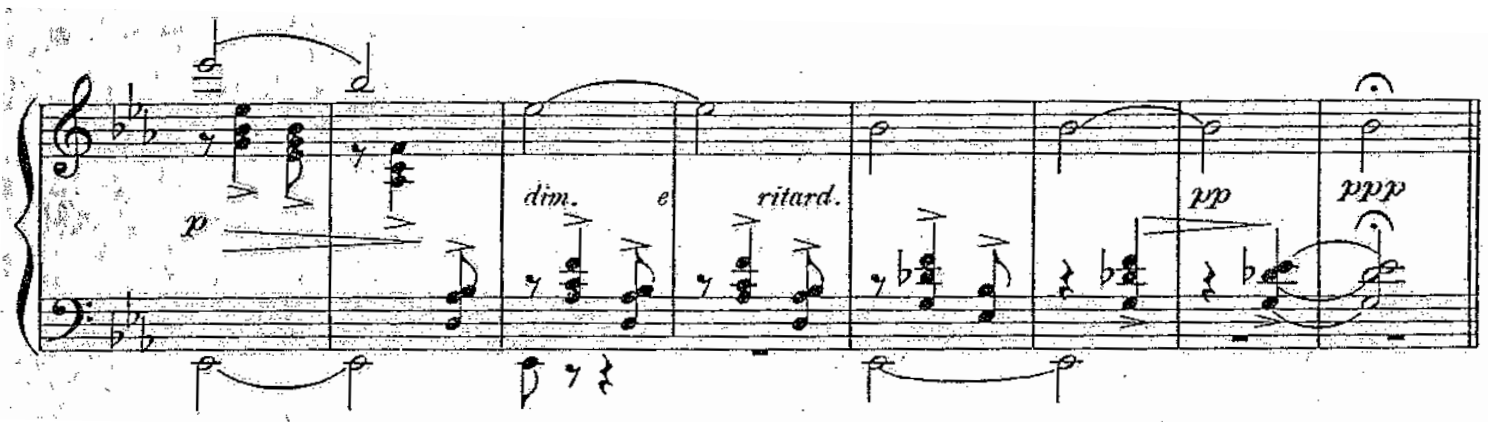

Each of the work's three sections starts with a two-measure left-hand introduction. The first two introductions make use of a quiet dynamic (piano) and the last section starts and ends quietly, perhaps resembling a peaceful evening full of contentment. A crescendo to piano leads to one final charming point of light on the last high Ab (example 4.1.6).

Example 4.1.6 Margaret Ruthven Lang: Starlight, mm. 113-122
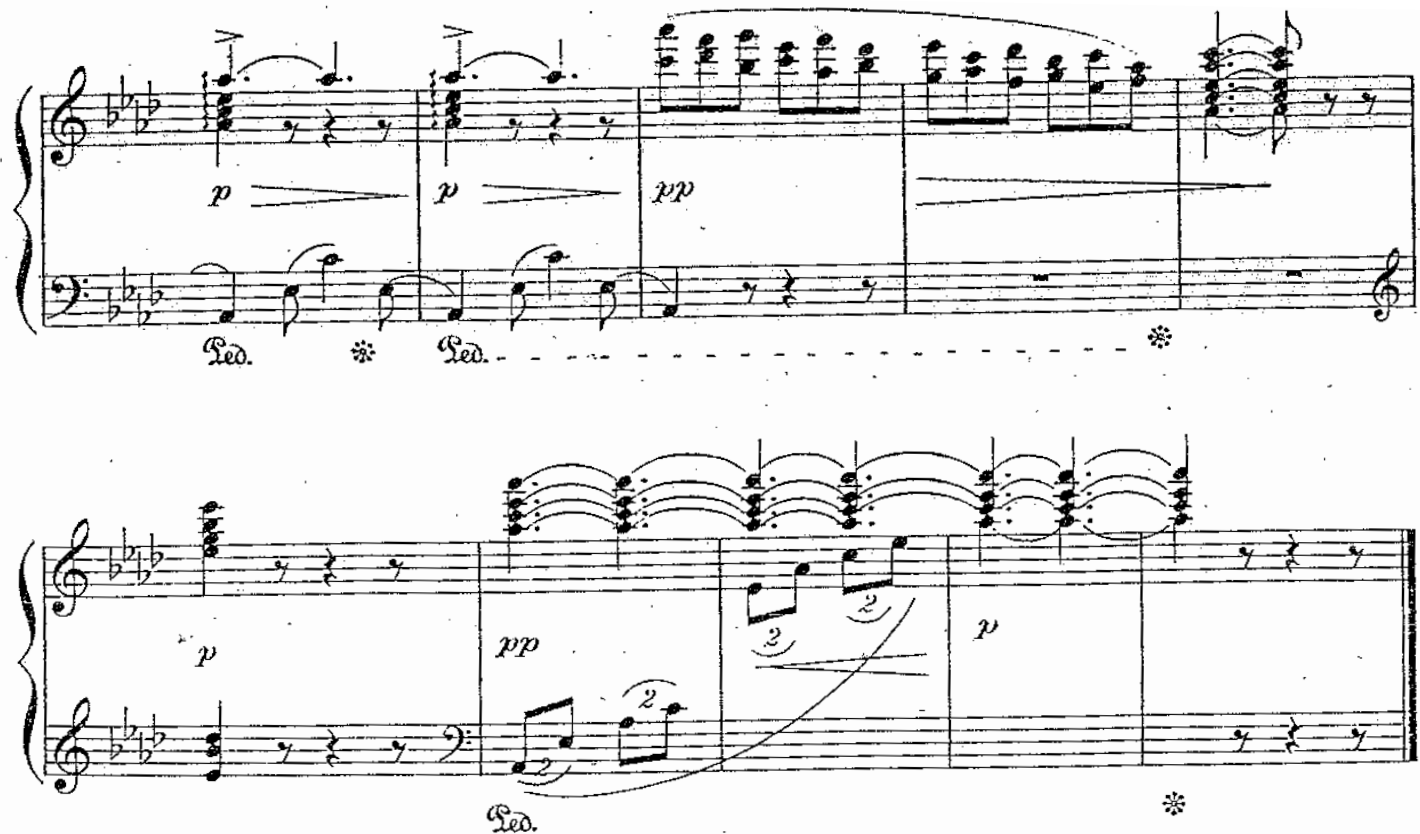


\section{Twilight}

Along with Starlight, Twilight was also published in Half Hours with the Best Composers, part 10 and dates from 1894. The piece has no opus number. Twilight not only shows similarities to Starlight with its emphasis on the quiet dynamics and intimate mood, but also a different side of Lang, incorporating wistful, American popular song harmonies. Seen below is one of the few extant manuscripts and also in the printed score (example 4.2):

Example 4.2.1 Margaret Ruthven Lang's manuscript

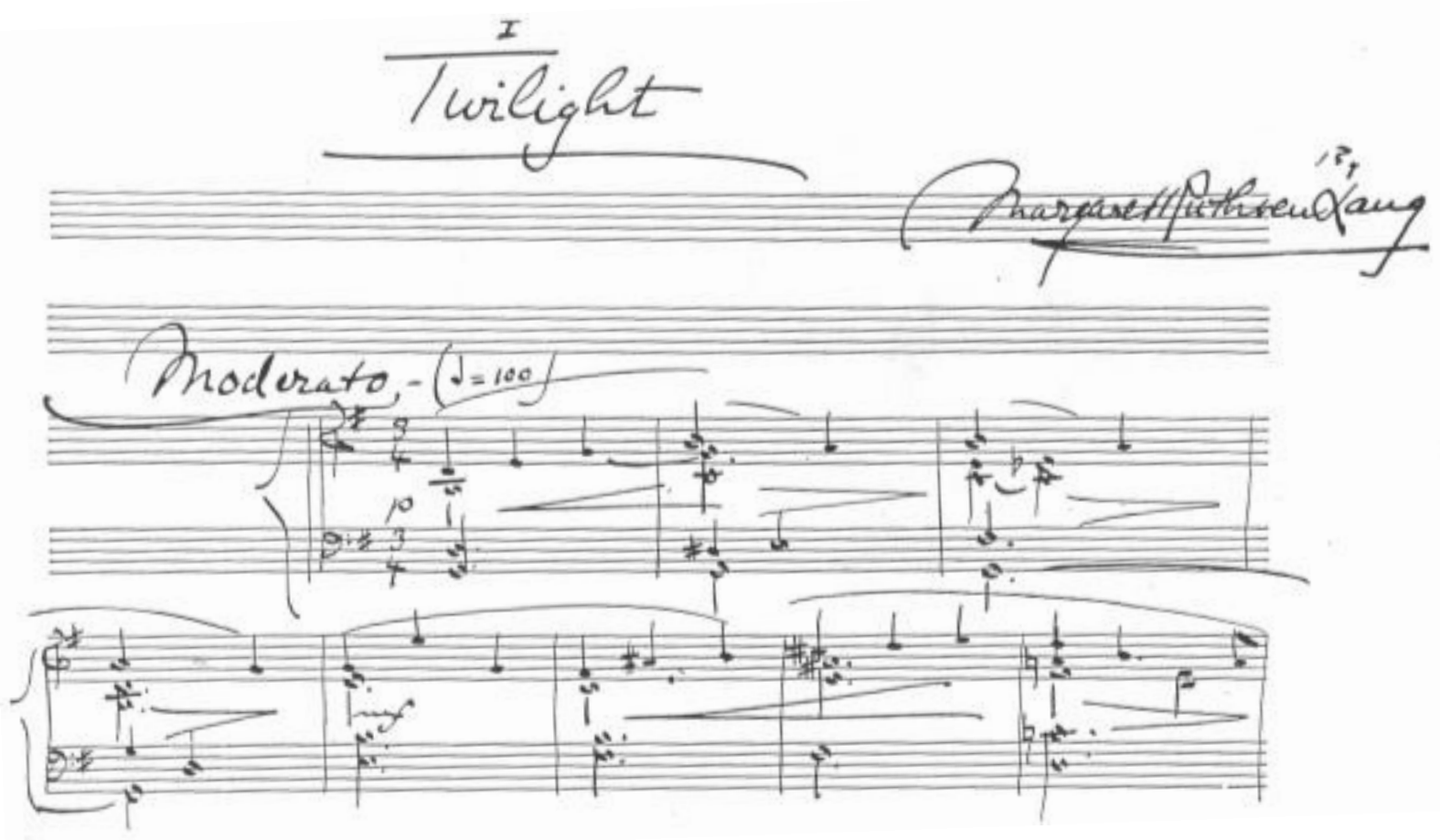


Example 4.2.2 Margaret Ruthven Lang: Twilight, mm. 1-34

Twilight.
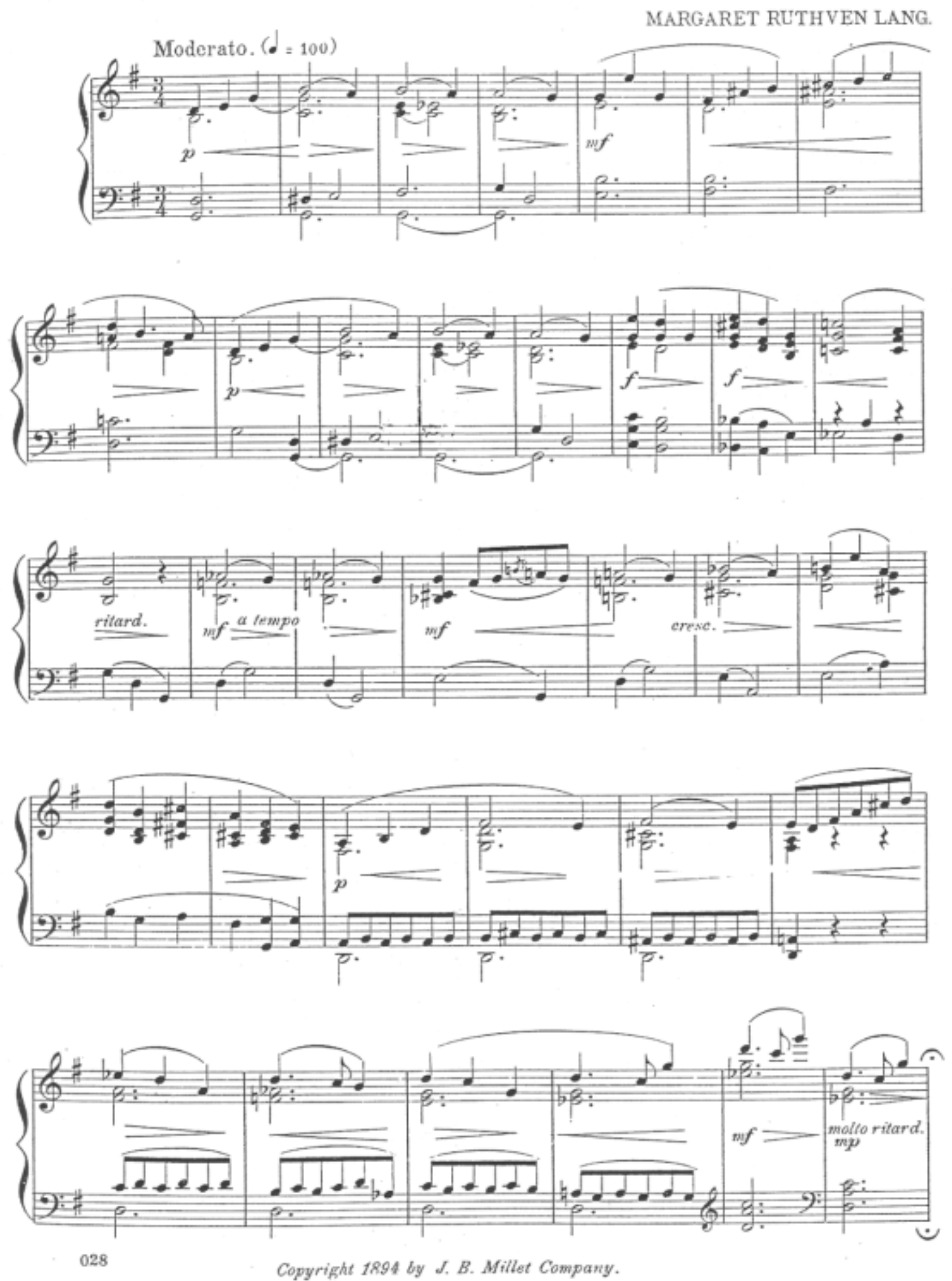
Lang uses a ternary form here. The first A section, marked Moderato, contrasts with the B section, marked Un poco piu mosso, in which the melody shifts to the left hand and the right hand plays an evocative accompaniment (example 4.2.3)

Example 4.2.3 Margaret Ruthven Lang: Twilight, mm. 35-51
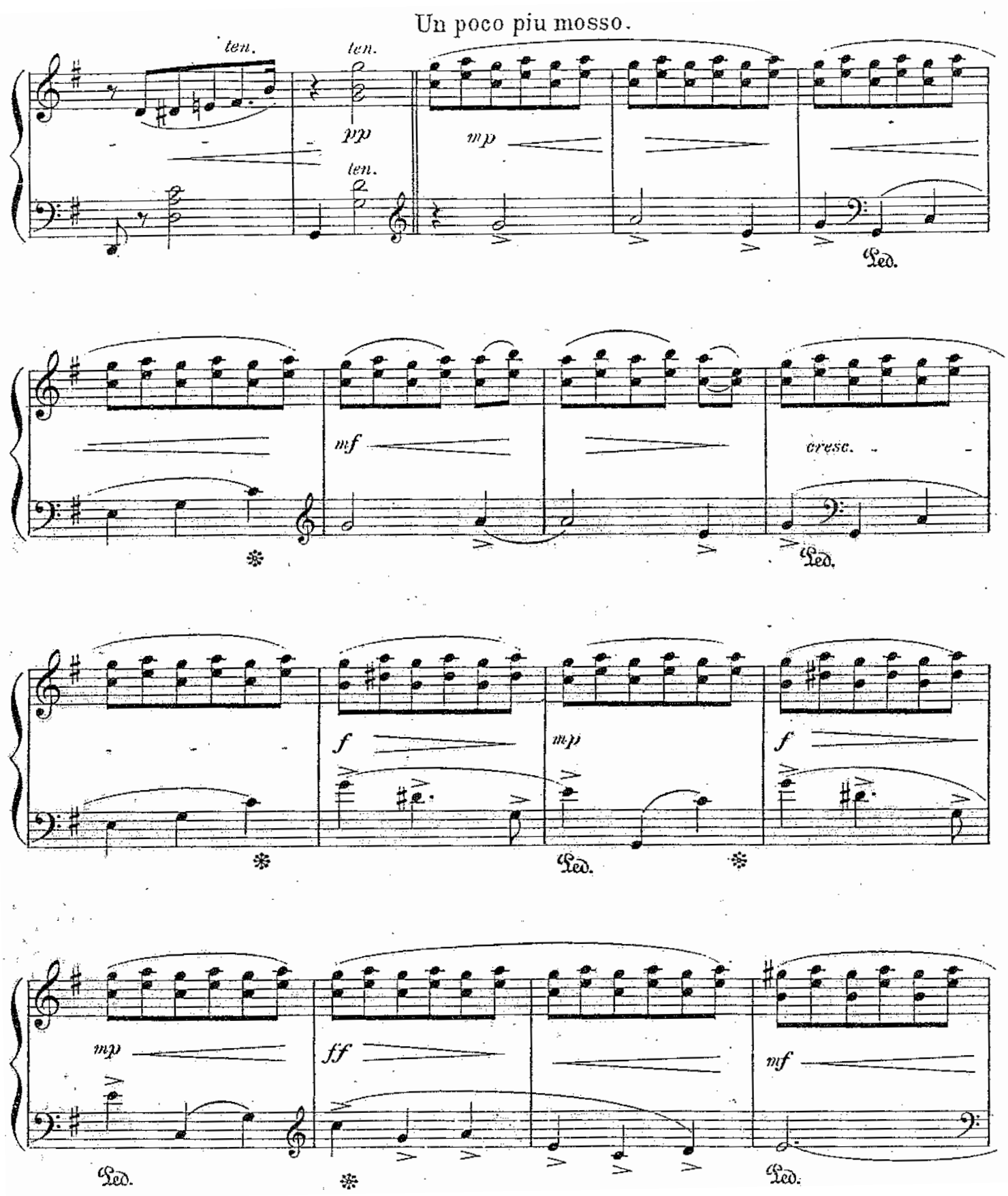
Pedal markings only appear in the B section. Both sections are written in simple triple meter. Once again dynamic and expression markings are detailed by Lang; these are helpful to the performer, but require much control of sound in both hands. This song has a narrower range than Starlight, reflecting the diffuse light of the twilight hour.

Challenges for the performer include mastering melodic shape in both the right and left hands. The B section is complicated by the evenness required in the beautiful right hand accompanying figure. Twilight is suitable for late intermediate or early advanced players. 


\section{CHAPTER V}

\section{PETIT ROMAN EN SIX CHAPITRES, OP. 18}

Lang continues her exploration of the character piece with the fascinating Petit Roman en six chapitres, op. 18 (Short Novel in Six Chapters). The work was published in 1894, a year after Lang's Witichis Overture was premiered at the World's Columbian Exposition in Chicago. At that time The Musical Courier wrote, "Margaret composed not only the music, but the accompanying story." ${ }^{48}$ Petit Roman is unique in the canon of piano repertoire: rarely does one find a multi-movement work that tells such a specific story. The story, the text of which Lang writes directly into the score throughout the movements, concerns three characters: the Knight, the Princess, and the Prince. It is a love story that ends tragically. Lang conveys her narration through descriptive texts in French within each movement; her sketches of the events and the characters are quite specific, through both the text and the music.

Petit Roman, consisting of six pieces of moderate length, can be considered Lang's most significant piano work. Heard in its entirety, all six movements comprise some 25 minutes. The pieces are technically the most demanding of all her piano works, with frequent use of octave passages, full chords, layered writing, rhapsodic accompaniments and advanced requirements in articulation and expressive content. She uses a variety of structures built on contrasting sections for the movements but with thematic unity found throughout the work. The fact that this work bears thematic linkage certainly contributes to the feeling that the work is a unified whole and meant to be

\footnotetext{
48،Boston Music Notes-Margaret Ruthven Lang,” Musical Courier, January 1895 as quoted in Johnston.
} 
presented as a group in its entirety, telling the complete story. Indeed, the work is cyclic in that the final movement quotes themes from all the previous movements.

Lang alternates between the major and minor modes between the movements. She provides effective musical material for each character, mood and scene, and the work as a whole exemplifies a skillful balance of unity and contrast between the overall scheme and the underlying scenes. This set, in a sense, represents Lang at her most exalted level of inspiration.

Lang's Petit Roman is well-designed to fit into the advanced repertoire on the basis of its large scope, the incorporation of various styles such as the barcarolle, rhapsody, and gavotte, and the overall technical, musical and interpretive demands. The piece could easily be choreographed, making for a particularly interesting artistic experience. Following are each of the movements in more detail.

\section{Le Chevalier (The Knight)}

In the first movement, Lang begins the story by stating that the Knight makes a visit to the Princess, speaking of love. It is written in G Major and cast in an ABA form with introduction. The introduction opens brilliantly, presenting seven measures of music with a mixture of sweeping and chordal passages marked Moderato, a kind of opening flourish to depict the dashing Knight. At the very last measure, the arpeggios lead smoothly into the theme, Tempo di Gavotte (example 5.1a). 
Example 5.1a Margaret Ruthven Lang: Petit Roman: Le Chevalier, op. 18 no. 1, mm. 1-11
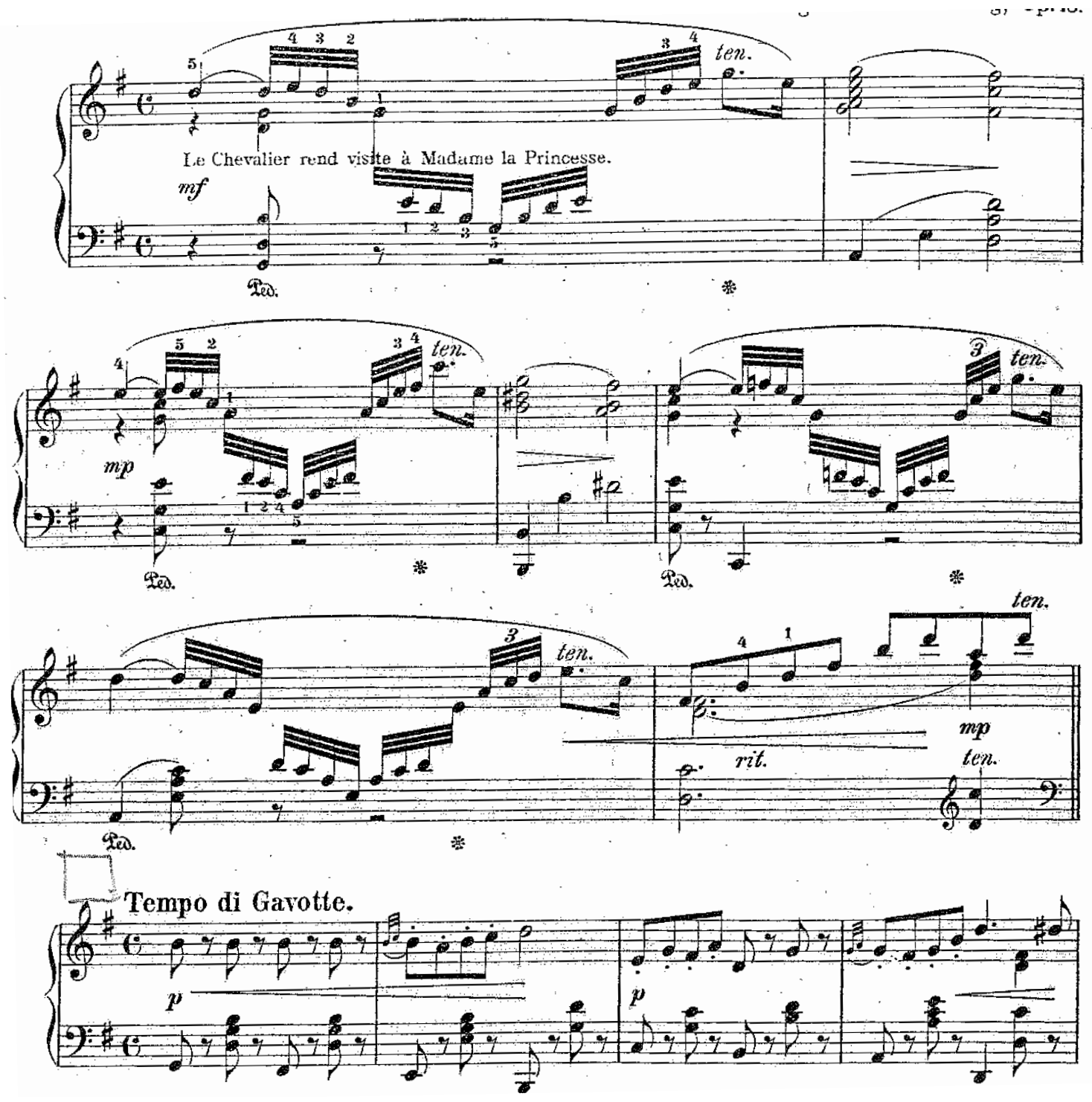

This Tempo di Gavotte gives a contrasting character to the introduction; it is a

French folk dance. According to Harriet Cavalli, the author of Dance and Music,

"Gavottes are [also] written in 4/4, 2/4, and $\not$. They are mostly courtly and elegant, with a distinct but indescribable, slightly subdued quality-..." ${ }^{, 49}$ In this case, Lang chose to use the Gavotte perhaps as a symbol of courtly love. A short bridge marked un poco piu

\footnotetext{
${ }^{49}$ Harriet Cavalli, Dance and Music: A Guide to Dance Accompaniment for Musicians and Dance Teachers (Florida: University Press, 2001), 30.
} 
mosso uses passagework inspired by the introduction and smoothly prepares the entrance of the B section (example 5.1b).

Example 5.1b Margaret Ruthven Lang: Petit Roman: Le Chevalier, op. 18 no. 1, mm. 35-43
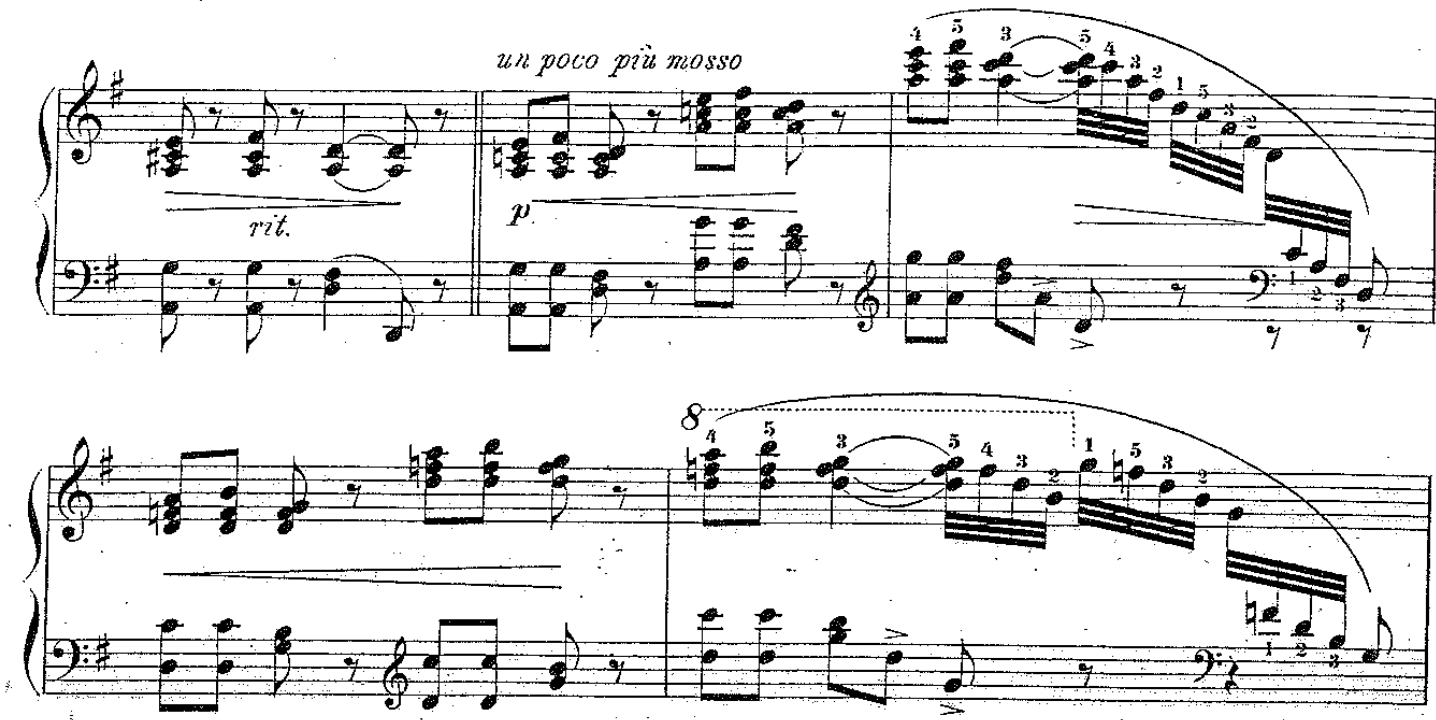

Moderato.

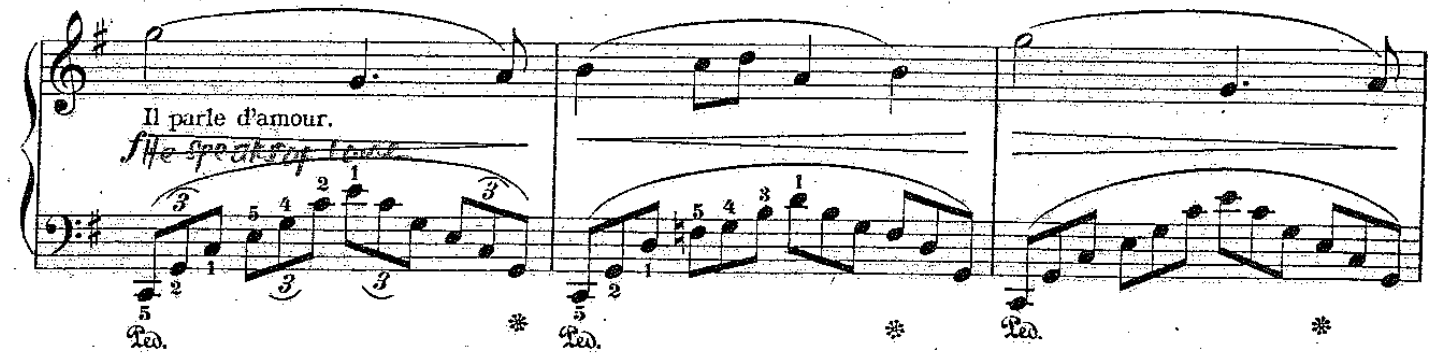

The B section, marked Moderato, is where the Knight "speaks of love.” Lang uses sweeping rhapsodic accompaniment figures and full chords along with sequential development to depict the Knight's ardent declaration of love (example 5.1c). 
Example 5.1c Margaret Ruthven Lang: Petit Roman: Le Chevalier, op. 18 no. 1, mm. 40-47
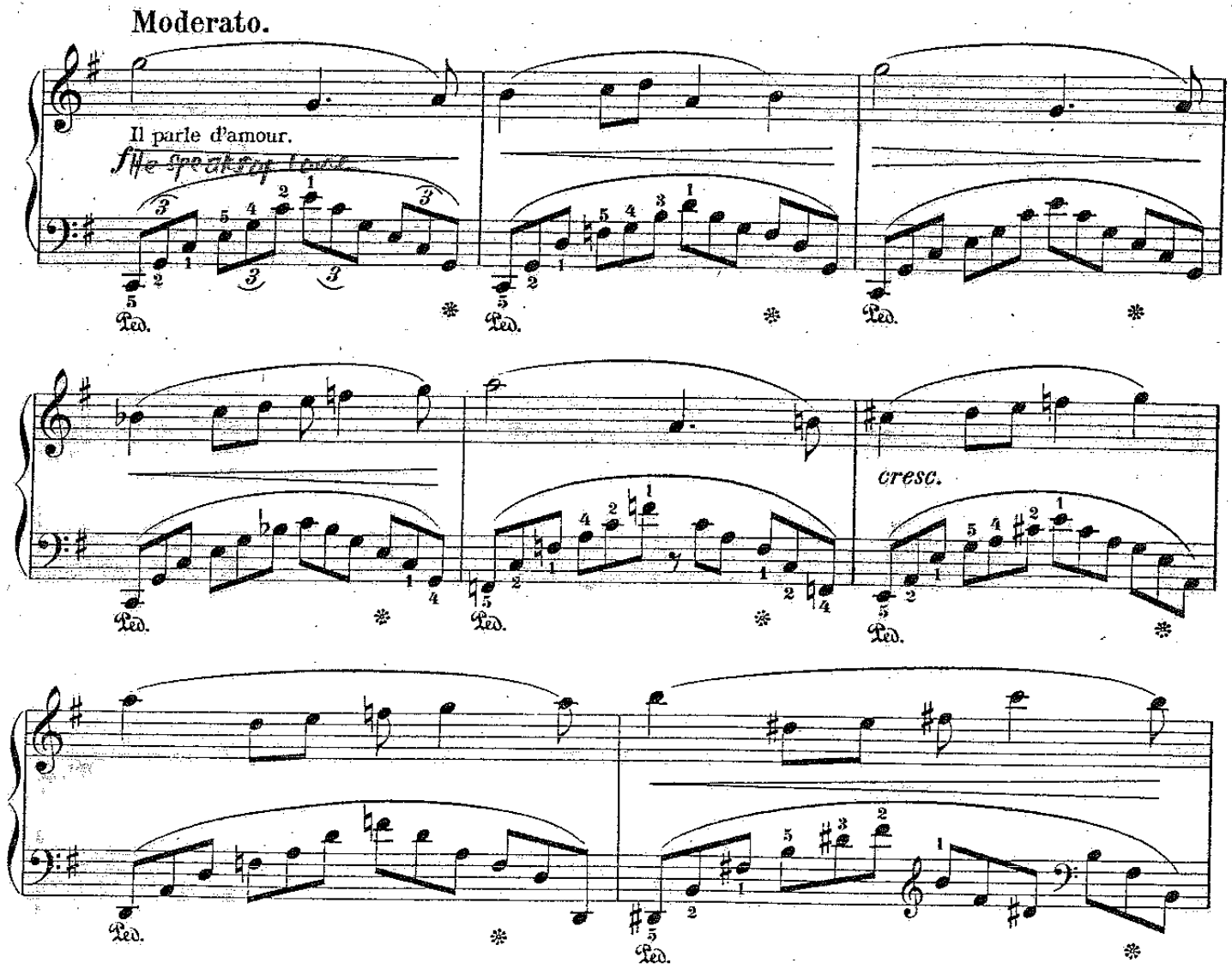

Upon the return to the main theme, she creates an a tempo section by marrying the two-measure patterns from both the Gavotte and the Moderato section, developing them sequentially with different intervals and harmonies, and thus returns to the opening theme, and the Knight's declaration is complete (example 5.1d).

Example 5.1d Margaret Ruthven Lang: Petit Roman: Le Chevalier, op. 18 no. 1, mm. 62-69

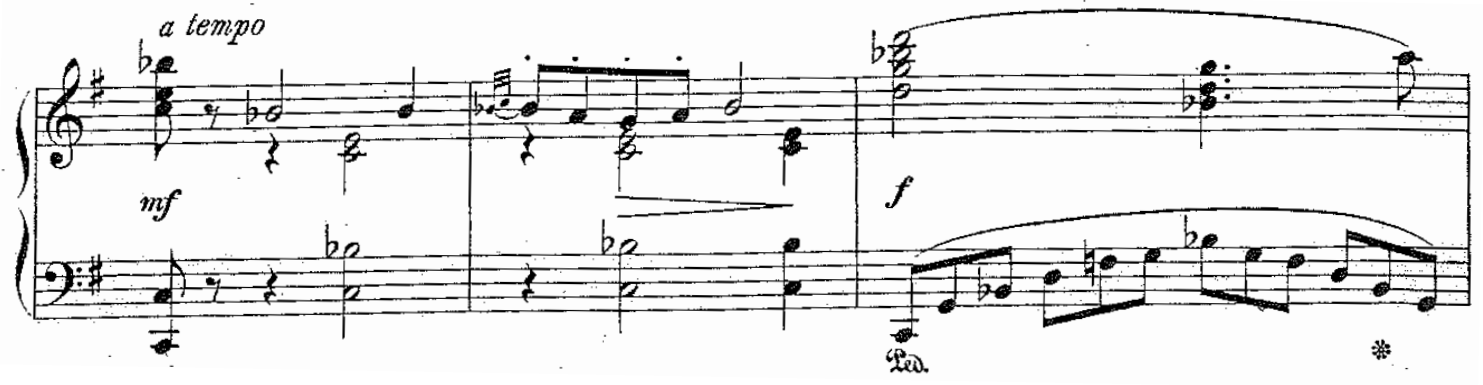



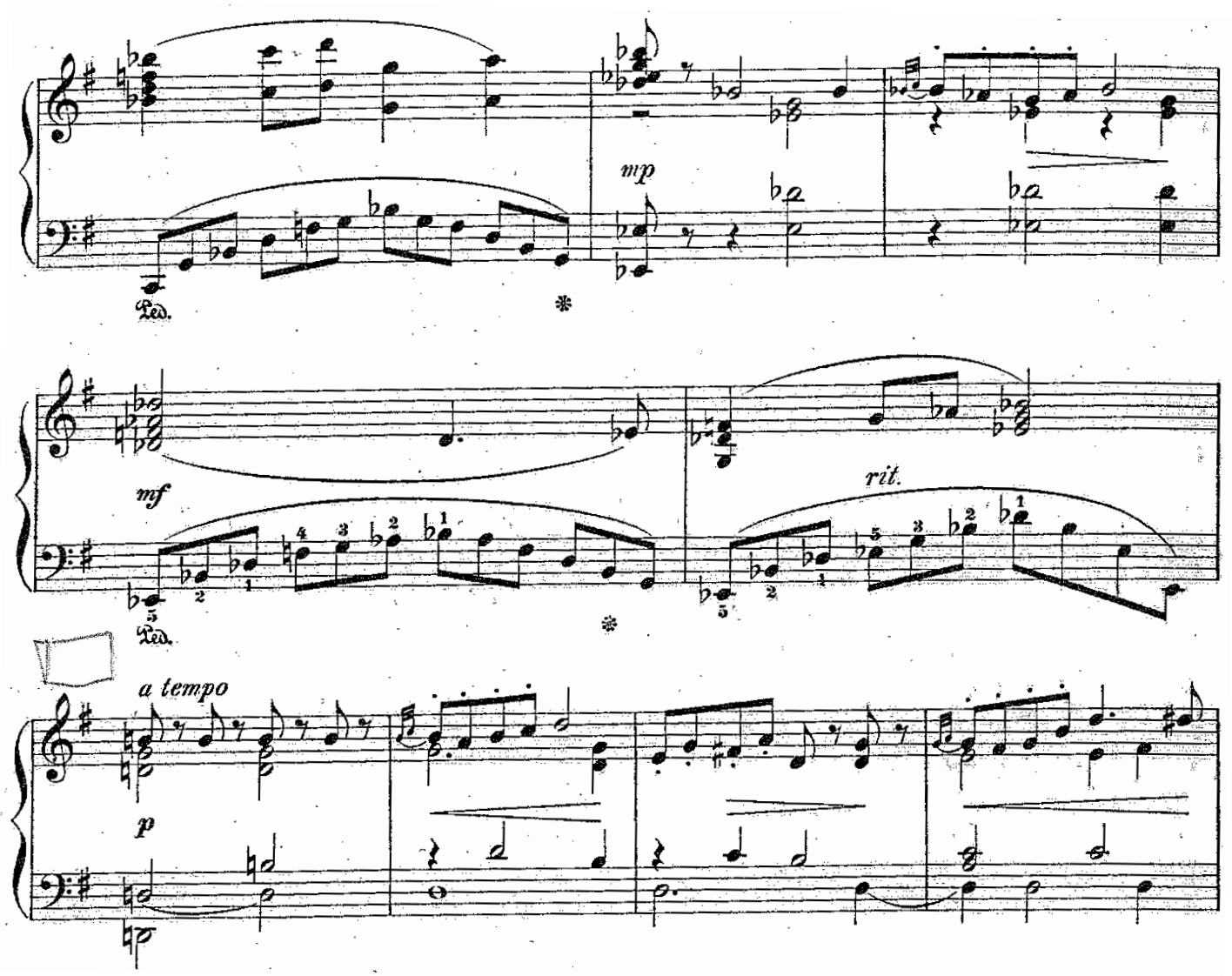

\section{Madame la Princesse (The Princess)}

In the second movement, in c minor, the Princess responds to the Knight with indifference. The four-measure introduction marked Moderato and taken from the Gavotte theme of the first movement, ends on a dominant chord, G Major, setting up the suspense as the Knight awaits her answer. The form of this work is Introduction-ABA. Lang describes the Princess's heartbeats and hesitation by the use of repeated alternating eighth notes and rests when the score says "The Princess responds to him." This introductory section in a simple quadruple meter leads to the Andantino (example 5.2a). 
Example 5.2a Margaret Ruthven Lang: Petit Roman: Madame la Princesse, op. 18 no. 2, mm. 114
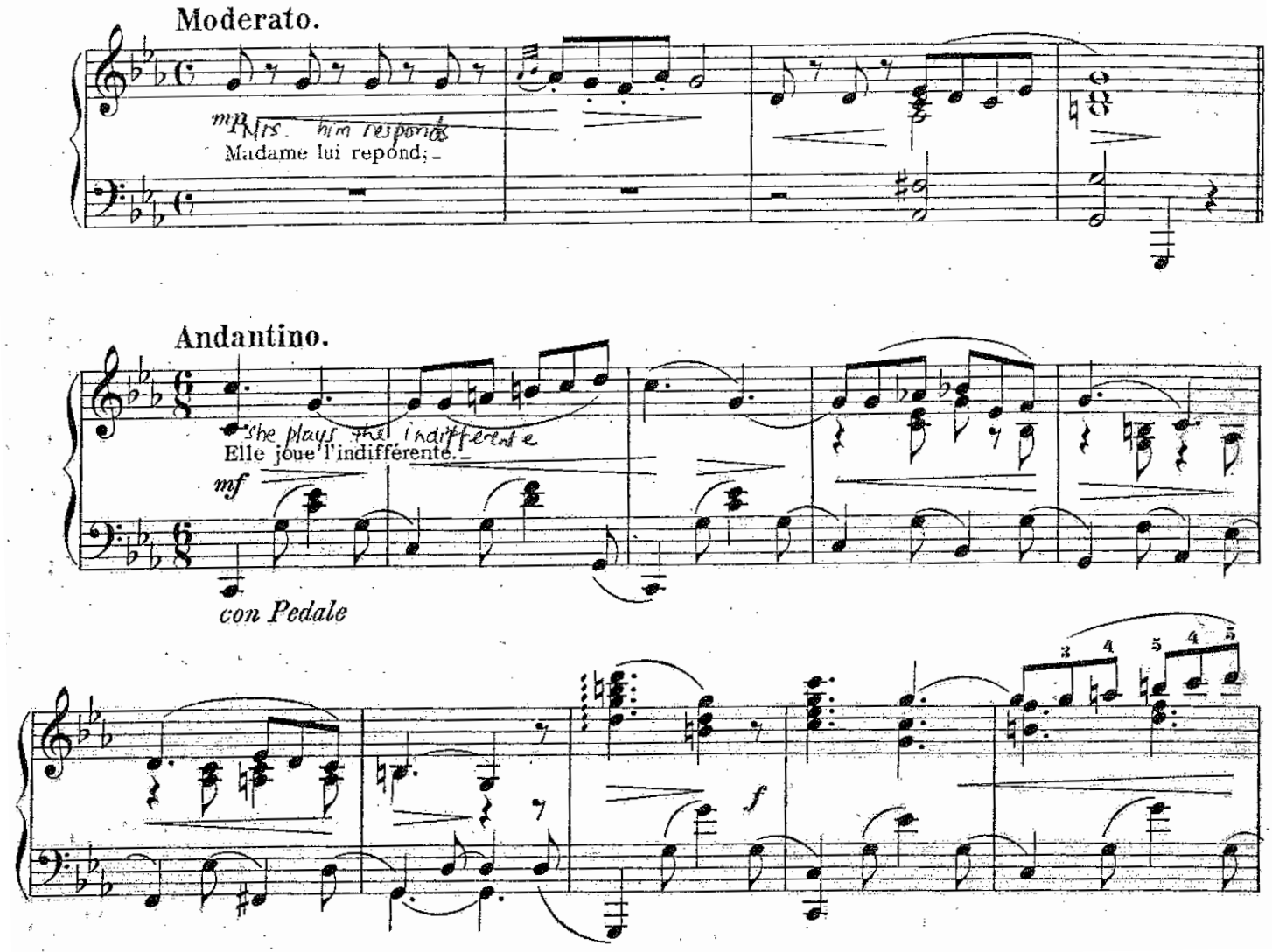

The beginning of this section, in which Lang writes, "She acts indifferent," is written in a compound duple meter in the style of a barcarolle. As Cavalli mentions in Dance and Music, "Originally songs of the Venetian gondoliers, barcarolles are especially obvious examples of the lilting rhythm ... because they almost always lack the second and fifth notes in both the melody and the rhythm.",50

As the A section continues, Lang heightens the tension with more chromatic harmonies and the use of a thicker texture that employs pedal point techniques in both hands (example 5.2b).

${ }^{50}$ Cavalli, Dance and Music, 30. 
Example 5.2b Margaret Ruthven Lang: Petit Roman: Madame la Princesse, op. 18 no. 2, mm. 21-39
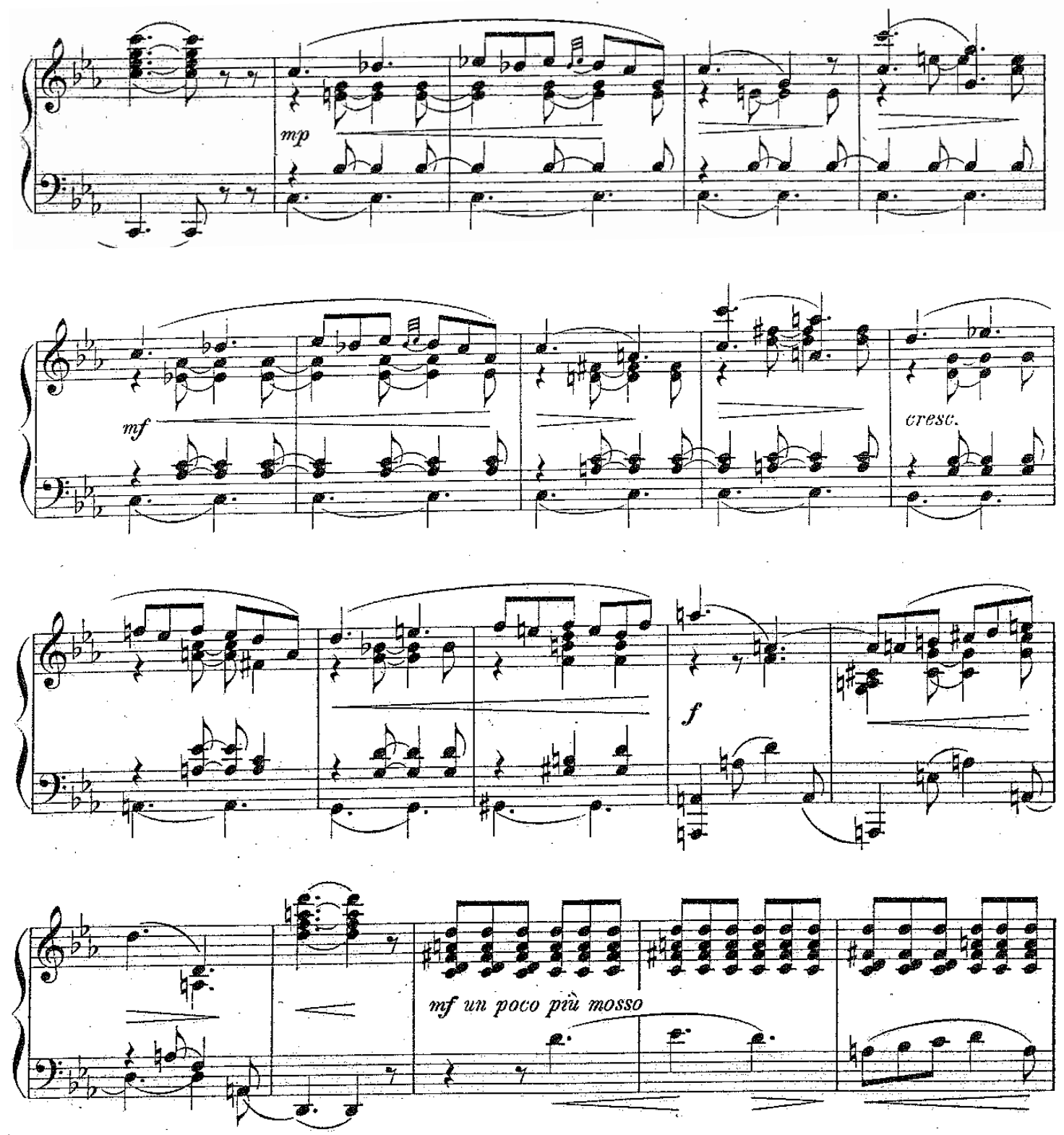

In mm. 37-44, the melody shifts to the left hand, and it marks the entrance of the B section. The repeated right hand chords and the faster tempo marking add to the sense of urgency found in this section. In mm. 45-61, the melody moves to the right hand, where Lang perhaps tries to depict the conversation between the Knight and the Princess (example 5.2c). 
Example 5.2c Margaret Ruthven Lang: Petit Roman: Madame la Princesse, op. 18 no. 2, mm. 4461
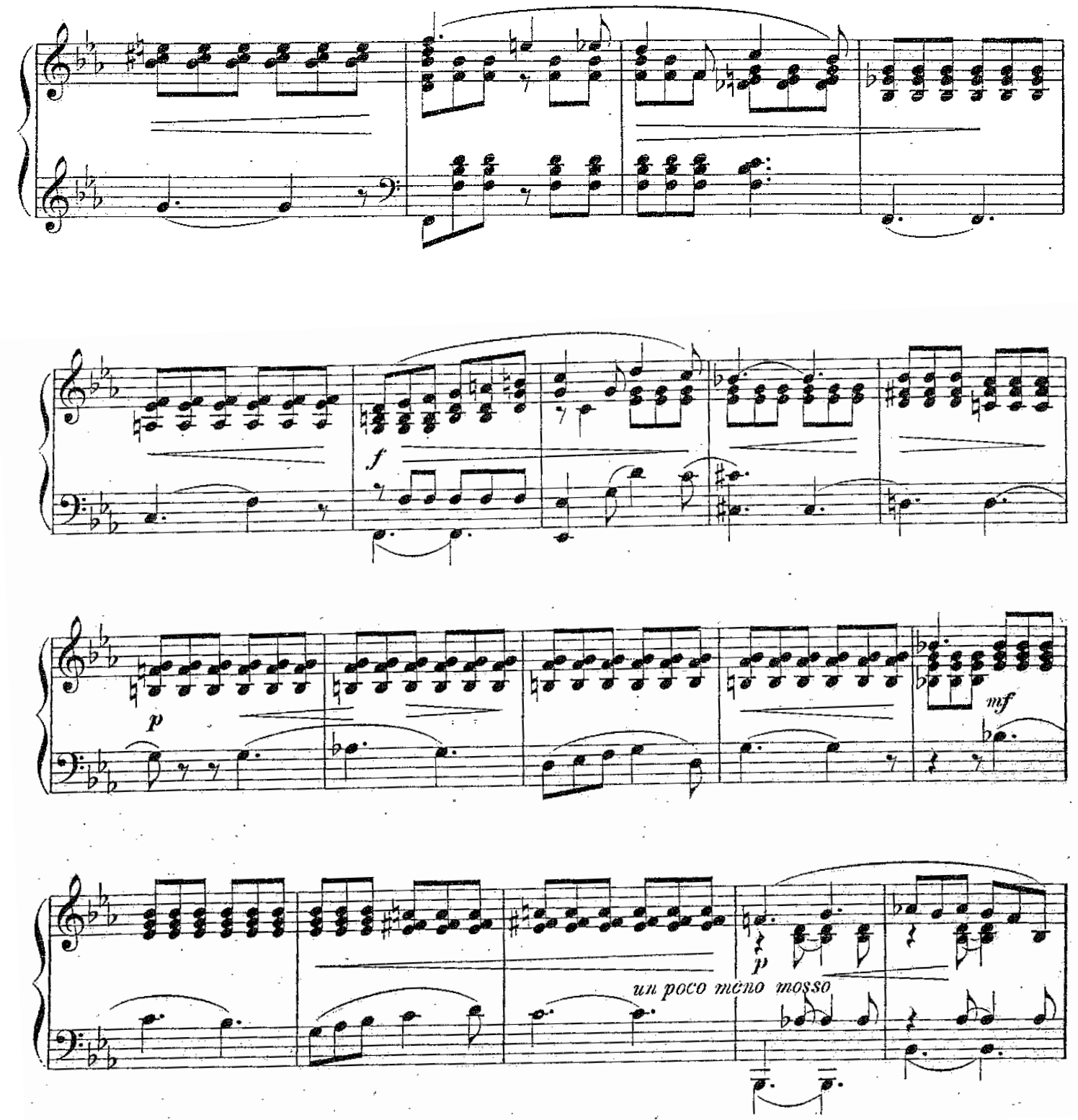

Before returning to the A section, Lang inserts a four-measure interlude that is drawn from the introduction, once again describing the hesitance of the Princess and the anticipation of the Knight (example 5.2d). 
Example 5.2d Margaret Ruthven Lang: Petit Roman: Madame la Princesse, op. 18 no. 2, mm. $77-82$

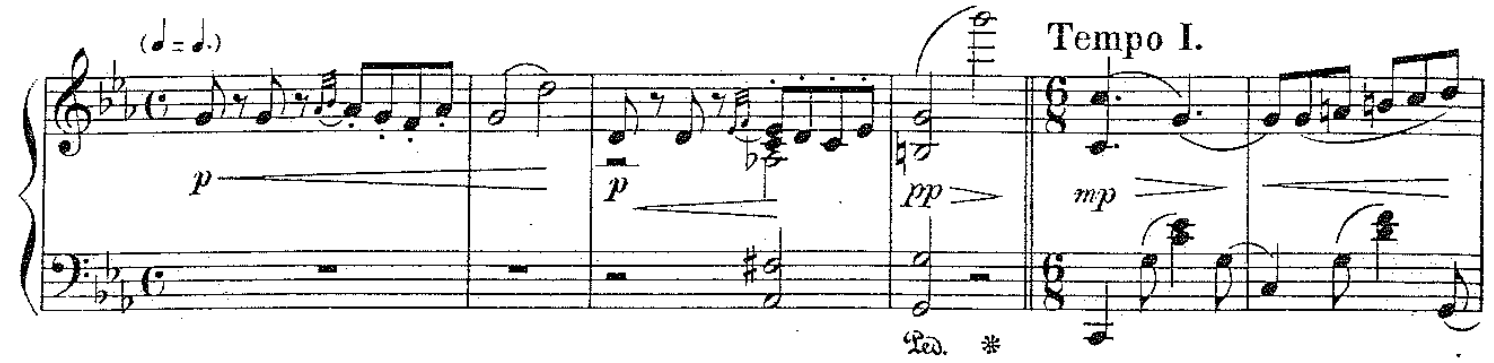

Surprisingly, Lang changes the mode of the barcarolle theme to the parallel major, $\mathrm{C}$, and closes with a one-measure wistful arpeggio marked Lento (example 5.2e).

Example 5.2e Margaret Ruthven Lang: Petit Roman: Madame la Princesse, op. 18 no. 2, mm. $77-106$
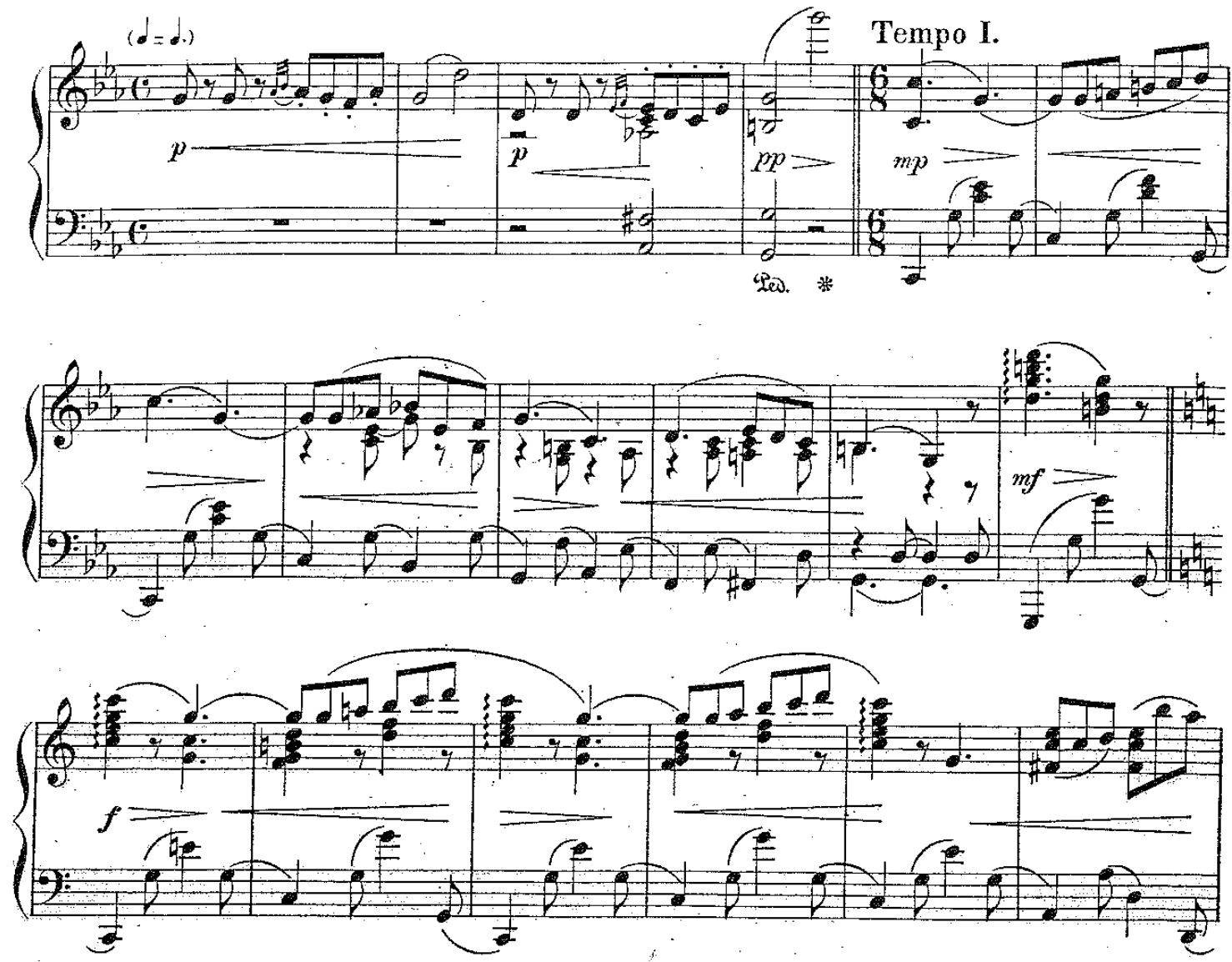

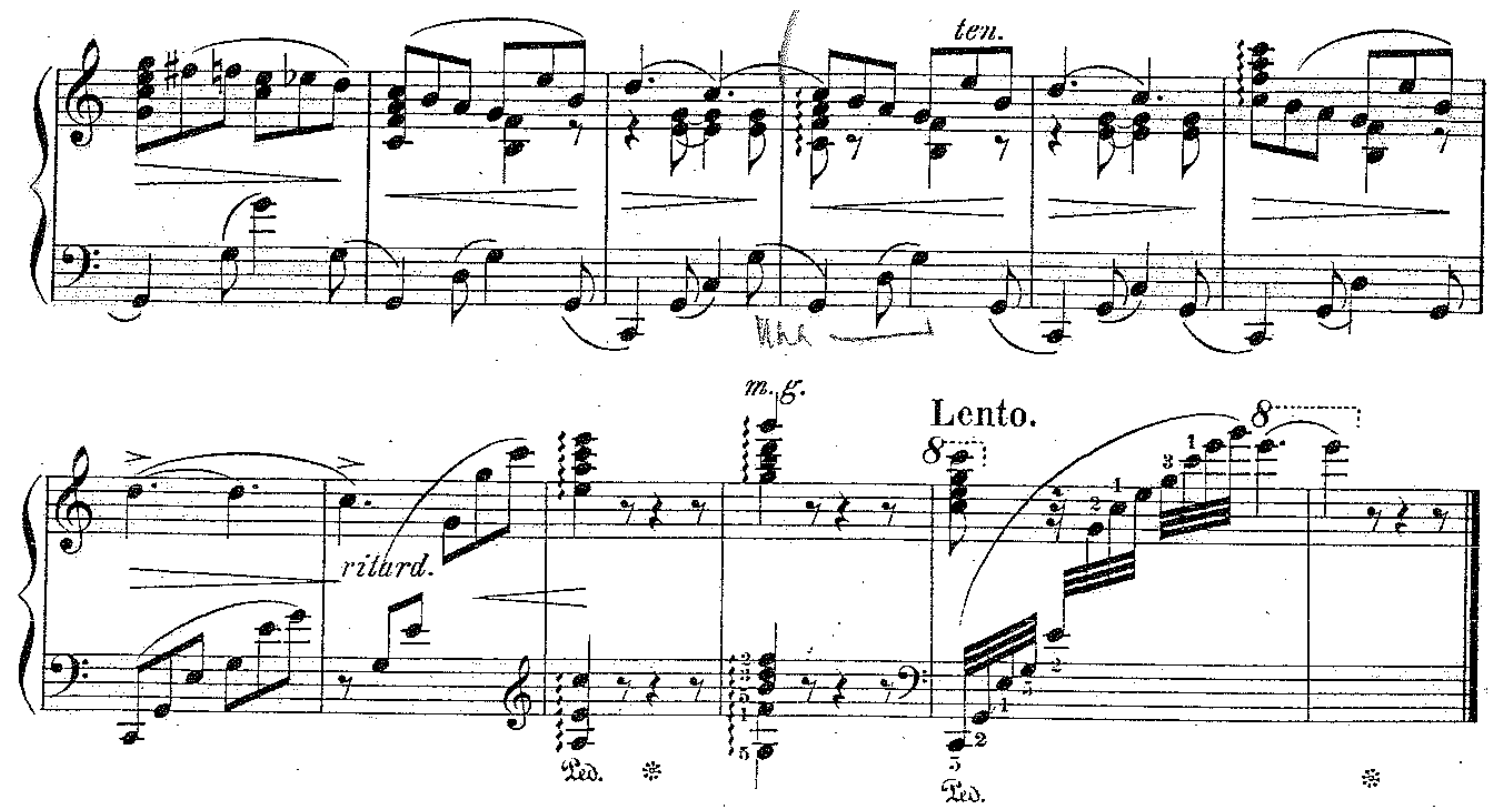

The piece ends in major, perhaps an indication that the Knight receives a positive response from the Princess. The story continues to the third movement.

\section{Bal chez Madame la Princesse (Ball at the Home of the Princess)}

Bal chez Madame la Princesse depicts a ballroom scene in which the Princess appears, the Knight sees her, and they dance. They pause for a moment, the Knight is enraptured, but still they dance. This movement is written in E Major, a third away from the previous movement's c minor/Major. This work is the first large movement encountered in the Petite Roman to have several narrative lines. Although the work is the longest in duration, the prevailing mood is one of delight. The formal scheme of this movement is similar to that of many of the Chopin waltzes, with much repetition of themes and contrasting sections (in this case, sections A through D) with a final coda. 
Lang's reference to the opening narrative, "The Princess appears," is very specific; this movement starts out by augmenting the theme from the previous movement, "Madame la Princesse," into a six-measure introduction before launching into a variety of dance themes (example 5.3a).

Example 5.3a Margaret Ruthven Lang: Petit Roman: Madame la Princesse, op. 18 no. 2, mm. 59

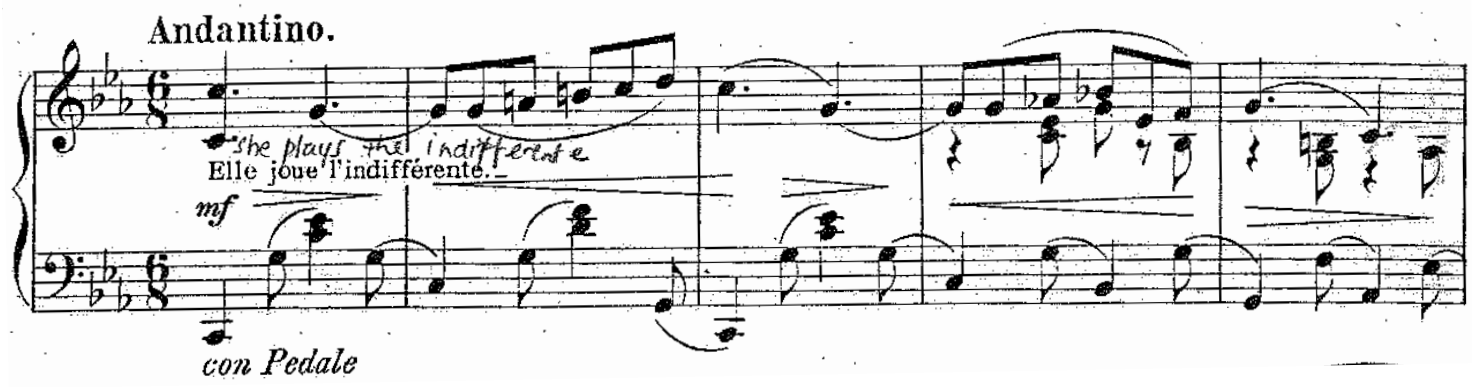

Example 5.3b Margaret Ruthven Lang: Petit Roman: Bal chez Madame la Princesse, op. 18 no. 3, mm. 1-11

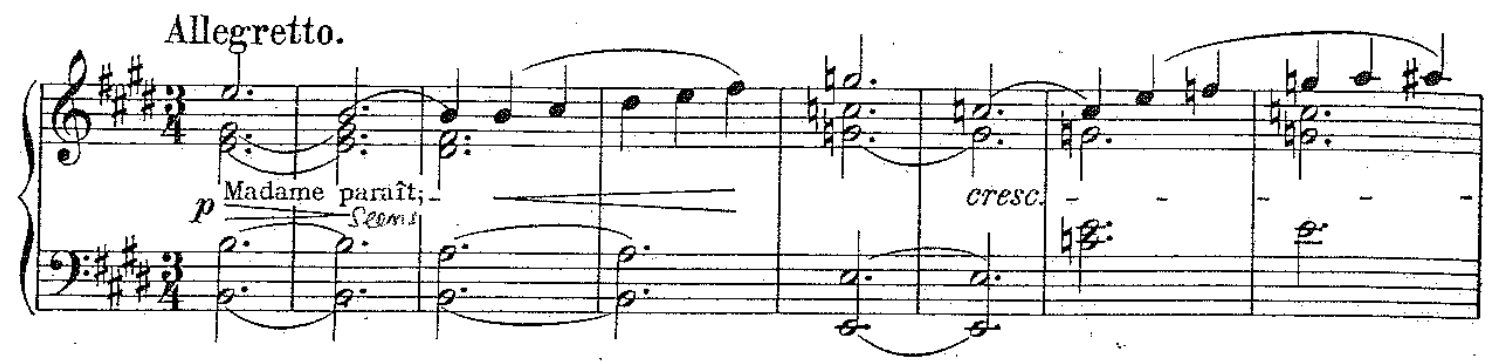

Again, Lang's creativity in recycling material and creating formal unity is witnessed from the use of the "he speaks of love" theme of the first movement that is transformed here as "the Knight sees her." Lang changes the rhythm to fit it into a danceable meter, simple triple, yet keeping a similar tune (example 5.3c). 
Example 5.3c Margaret Ruthven Lang: Petit Roman: Le Chevalier, op. 18 no. 1, mm. 40-41

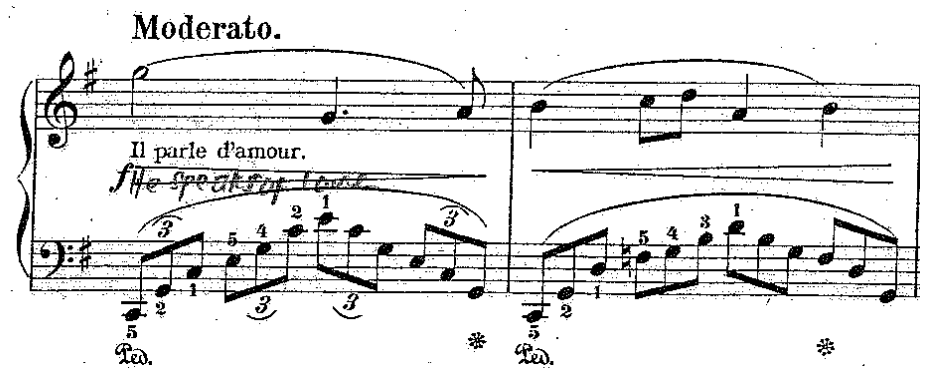

Example 5.3d Margaret Ruthven Lang: Petit Roman: Bal chez Madame la Princesse, op. 18 no. 3, mm. 9-12

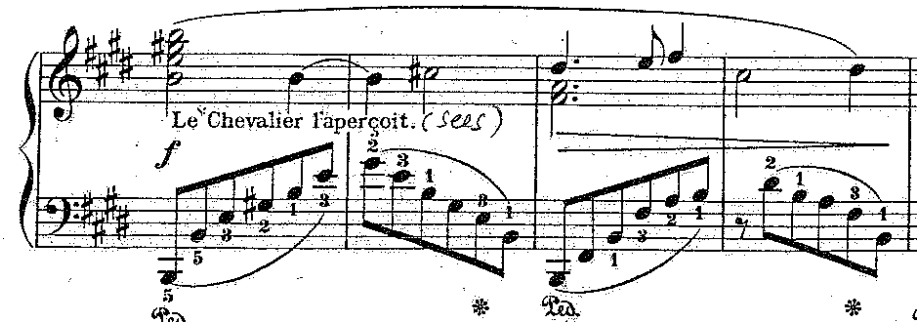

The dance begins when the waltz is introduced in the B section. The score says,

“They dance." It is a pleasant dance and they have a charming moment. Lang's melodic writing for the right hand captures the spirit of the waltz beautifully (example 5.3e).

Example 5.3e Margaret Ruthven Lang: Petit Roman: Bal chez Madame la Princesse, op. 18 no. 3, mm. 35-47
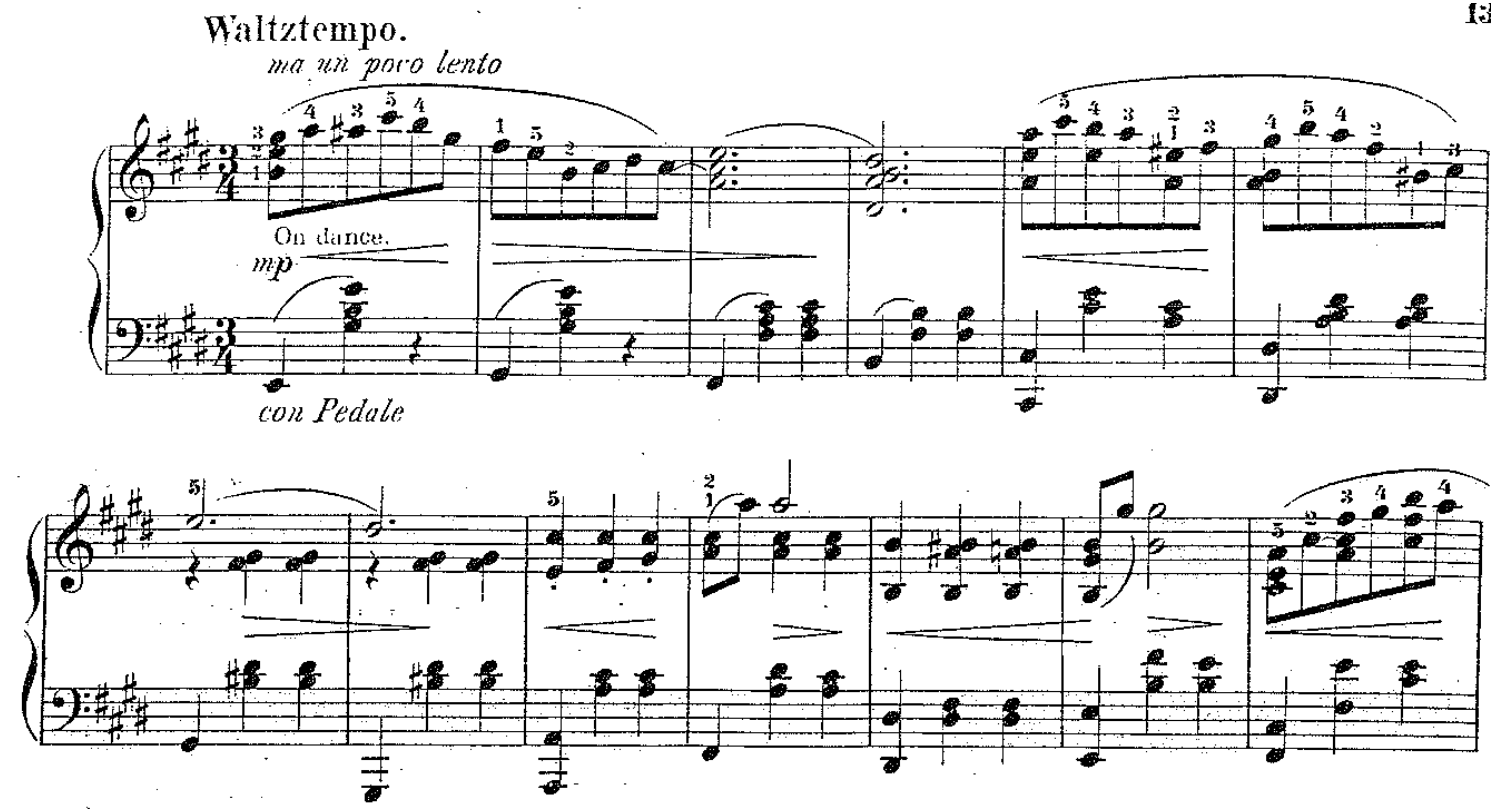
The $\mathrm{C}$ section starts with a c-sharp minor chord. The octave in the right and left hands on the downbeat of each measure and the descending line of the phrase capture a spirit of wistful lilt and masculinity (example 5.3f).

Example 5.3f Margaret Ruthven Lang: Petit Roman: Bal chez Madame la Princesse, op. 18 no. 3, mm. 82-109
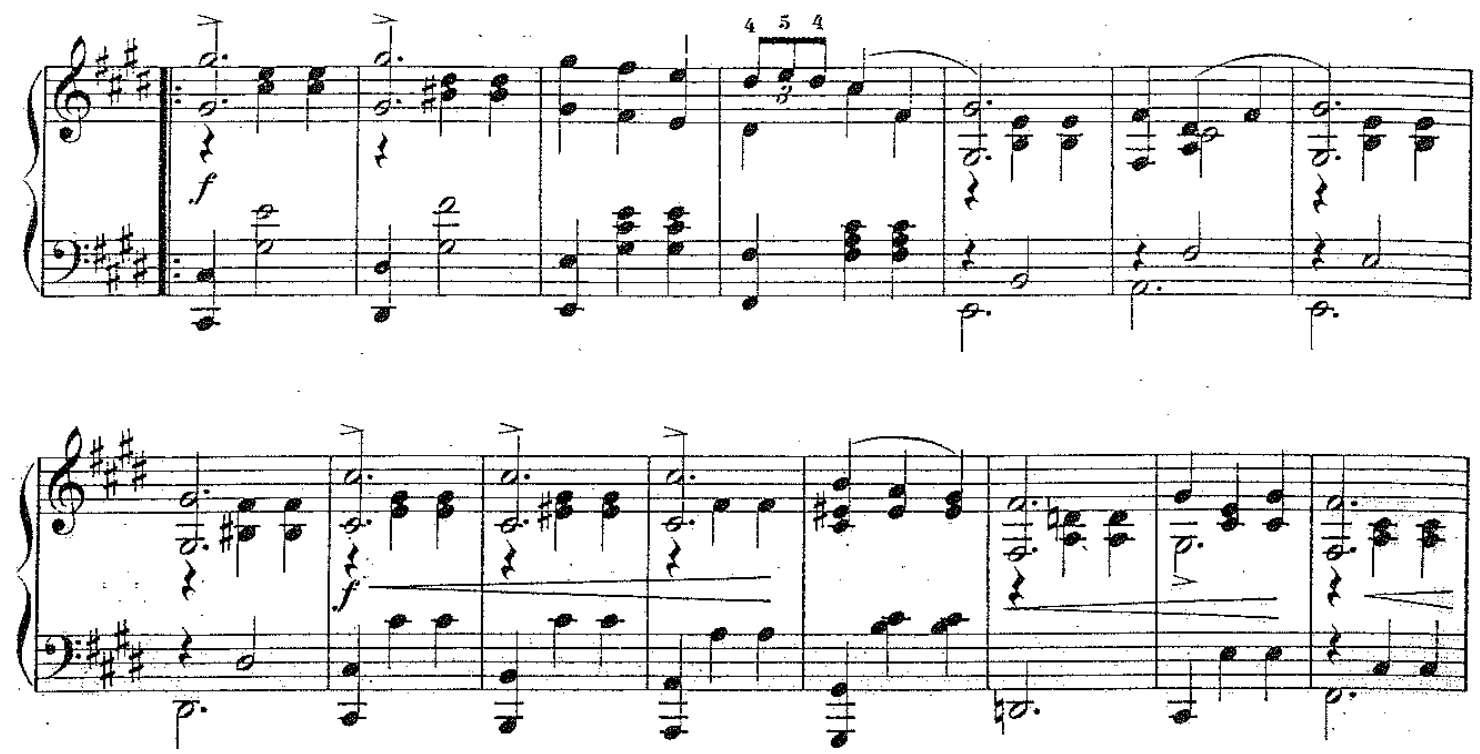

The arrival of the D theme brings back the sweet character and charming sentiment. Lang uses a single melodic line in upward motion giving the impression of graceful, flirtatious movement. She marks this section con grazia e delicatezza. A short interlude captures a moment of repose (example 5.3g).

Example 5.3g Margaret Ruthven Lang: Petit Roman: Bal chez Madame la Princesse, op. 18 no. 3, mm. 82-109

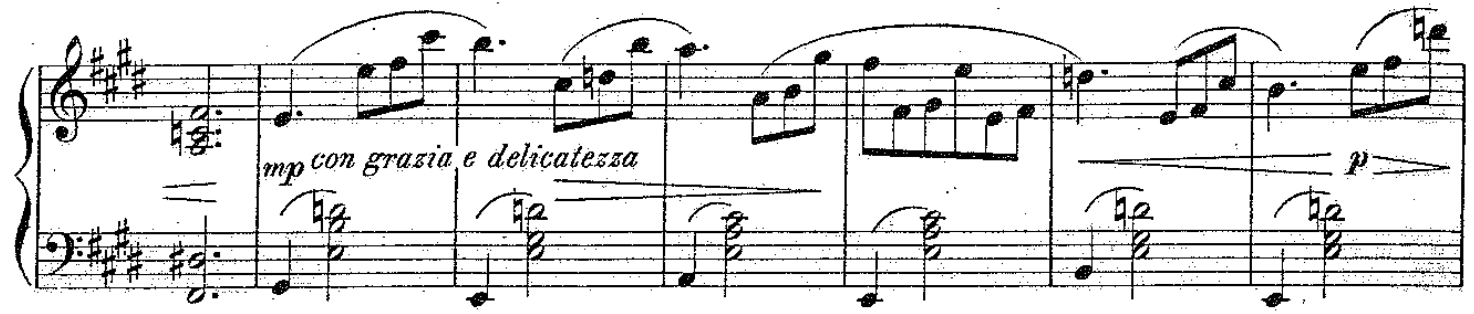



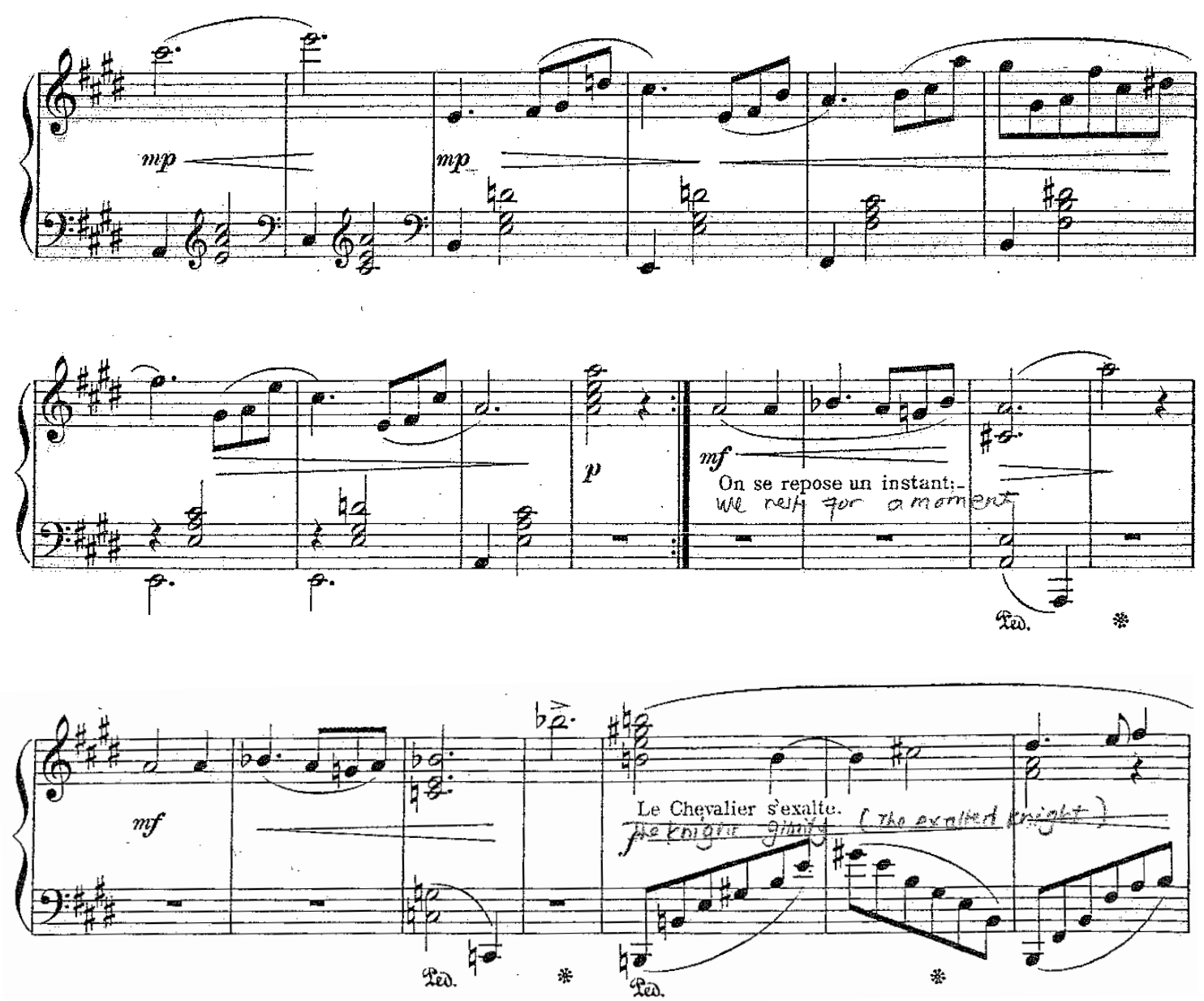

As the music continues, "They rest a moment." The waltz is interrupted by the insertion of this short interlude, transformed from fragments of the "Princess responds to him" theme, signifying that she too loves the Knight (example 5.3h).

Example 5.3h Margaret Ruthven Lang: Petit Roman: Madame la Princesse, op. 18 no. 2, mm. 14

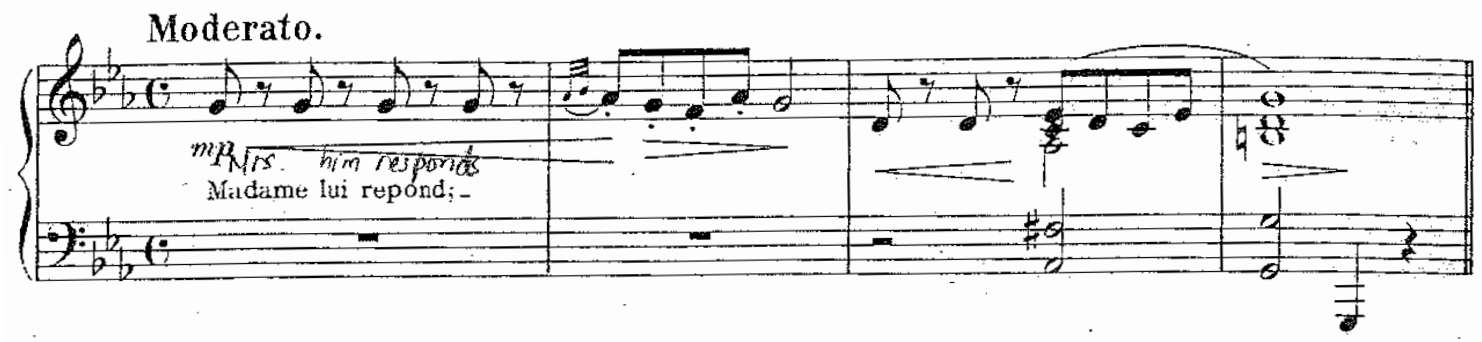


Example 5.3i Margaret Ruthven Lang: Petit Roman: Bal chez Madame la Princesse, op. 18 no. 3, mm. 99-106
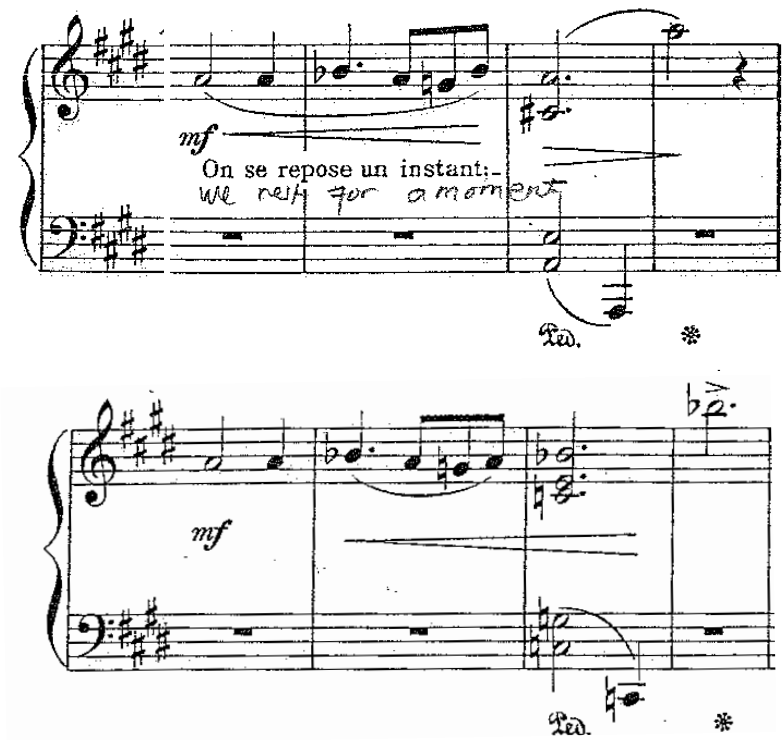

The A, B, C, and D sections are reprised. The return of the A section states that "the Knight is enraptured," as he now senses her love for him (example 5.3j). This is followed by "Still, they dance" upon the arrival of the B, C, and D sections of the waltz (example 5.3k).

Example 5.3j Margaret Ruthven Lang: Petit Roman: Bal chez Madame la Princesse, op. 18 no. 3, mm.103-109

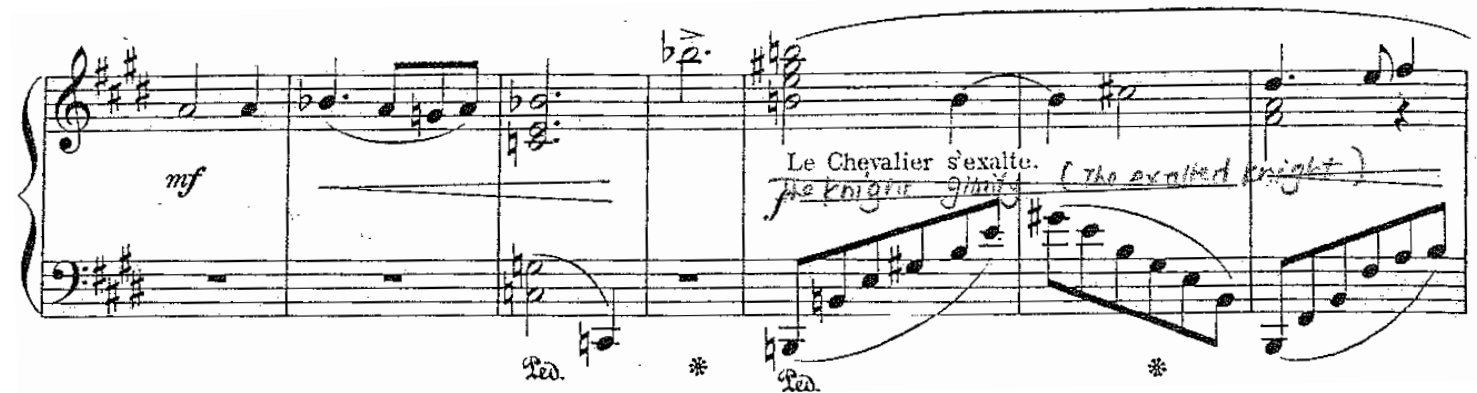

Example 5.3k Margaret Ruthven Lang: Petit Roman: Bal chez Madame la Princesse, op. 18 no.3, mm. 133-139

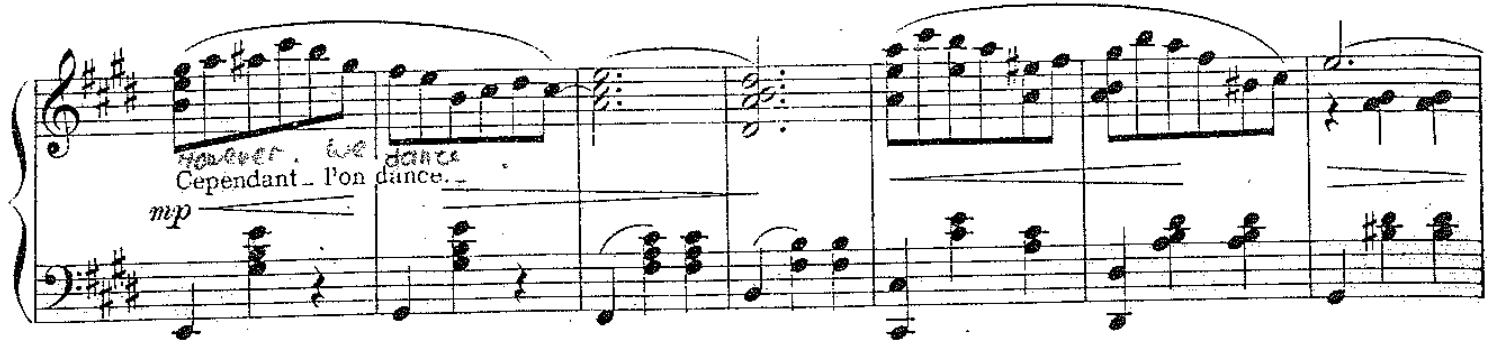


Finally, a climax and coda bring the piece to an exciting close (example 5.31).

Example 5.31 Margaret Ruthven Lang: Petit Roman: Bal chez Madame la Princesse, op. 18 no. 3, mm. 188-202
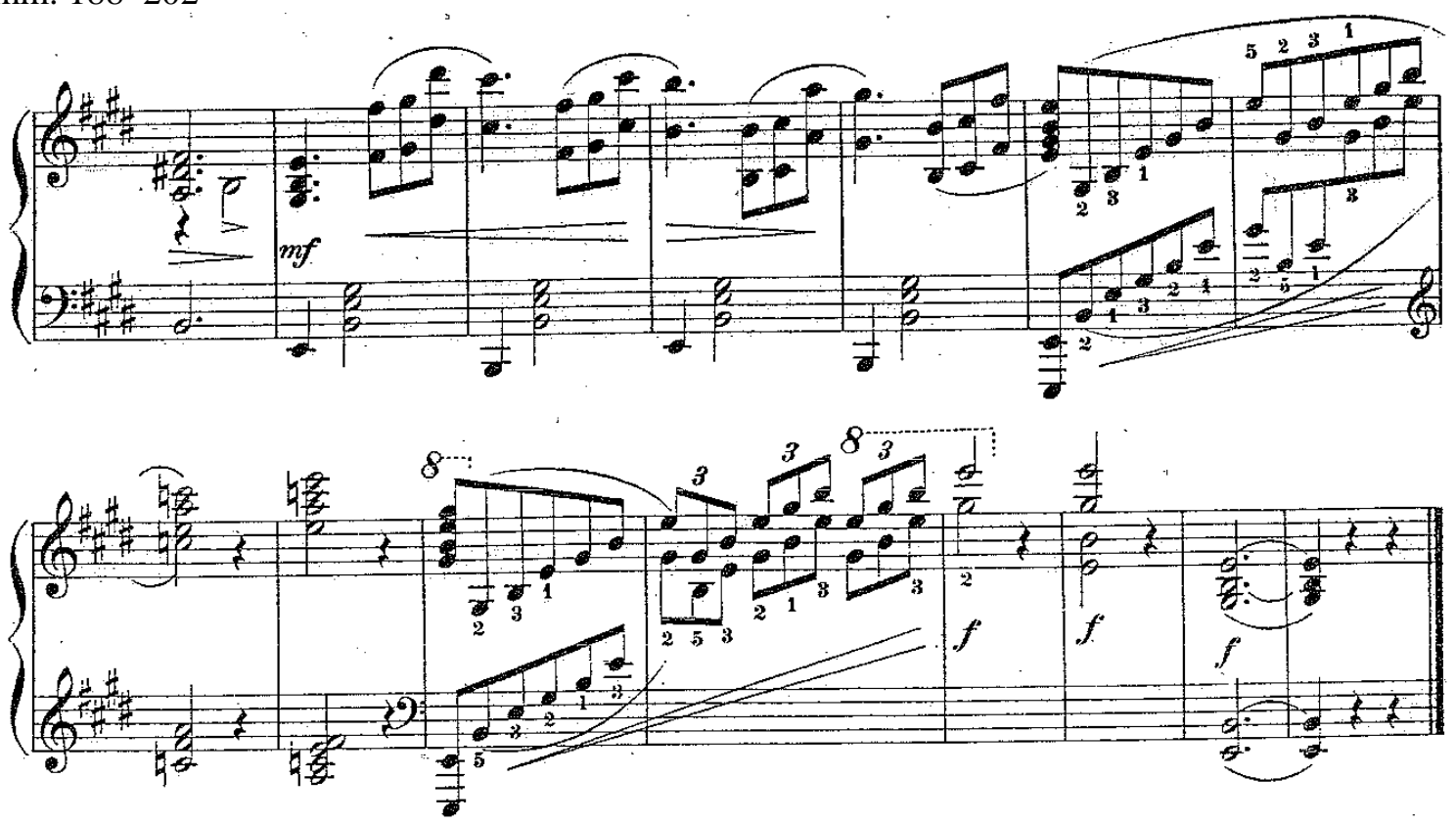

About this movement, Karleton Hackett, an American music critic, lecturer, voice

teacher, and an associate director of the American Conservatory of Music in Chicago,

writes,

The romance has to do with the adventures of the Chevalier and the Prince, the affair terminated by a duel and a neat funeral march and epitaph upon the defunct. The duel, no doubt, grew out of the little waltz with which we are just here dealing. It seems to have been a pleasant ball, that of the Princess, and when the couple has at last gotten their places and the dance begins, they appear to have a charming time. It is a light, airy and agreeable waltz. After the first figures are finished there is a moment of repose, and here the Chevalier begins to "exalt himself," as the French explanations gracefully have it. Miss Lang expresses this exaltation by means of the syncopations and the long running arpeggios in the bass. It is a pity that the English language could not have been used for the explanations, for while French may be understood in Boston, and therefore to have been preferred, there are school children even in Boston who know nothing of this language, and outside Boston the United States contains some millions of folk who understand English better than any kind of foreign tongue whatever. The music, however, is cosmopolitan. ${ }^{51}$

\footnotetext{
${ }^{51}$ Mathews, The Great in Music: A Systematic Course of Study in the Music of Classical and Modern Composers, 281-82.
} 


\section{Monsieur le Prince (The Prince)}

In this movement, the Prince is introduced for the first time. He thinks of the visit by the Knight to the home of the Princess and remembers that he is the Prince. He thinks of vengeance, hesitates, recalls her again and hesitates no more. Lang captures the dignity and outrage of the prince in this dramatic movement written in $\mathrm{g}$ minor, a third away from the previous movement and in simple triple meter. The formal scheme is ABCA.

In this fourth piece, Lang contrasts the grand, heroic opening motive of the Prince with a more urgent (example 5.4a) and restless second theme (example 5.4b).

Example 5.4a Margaret Ruthven Lang: Petit Roman: Monsieur le Prince, op. 18 no. 4, mm. 1-10
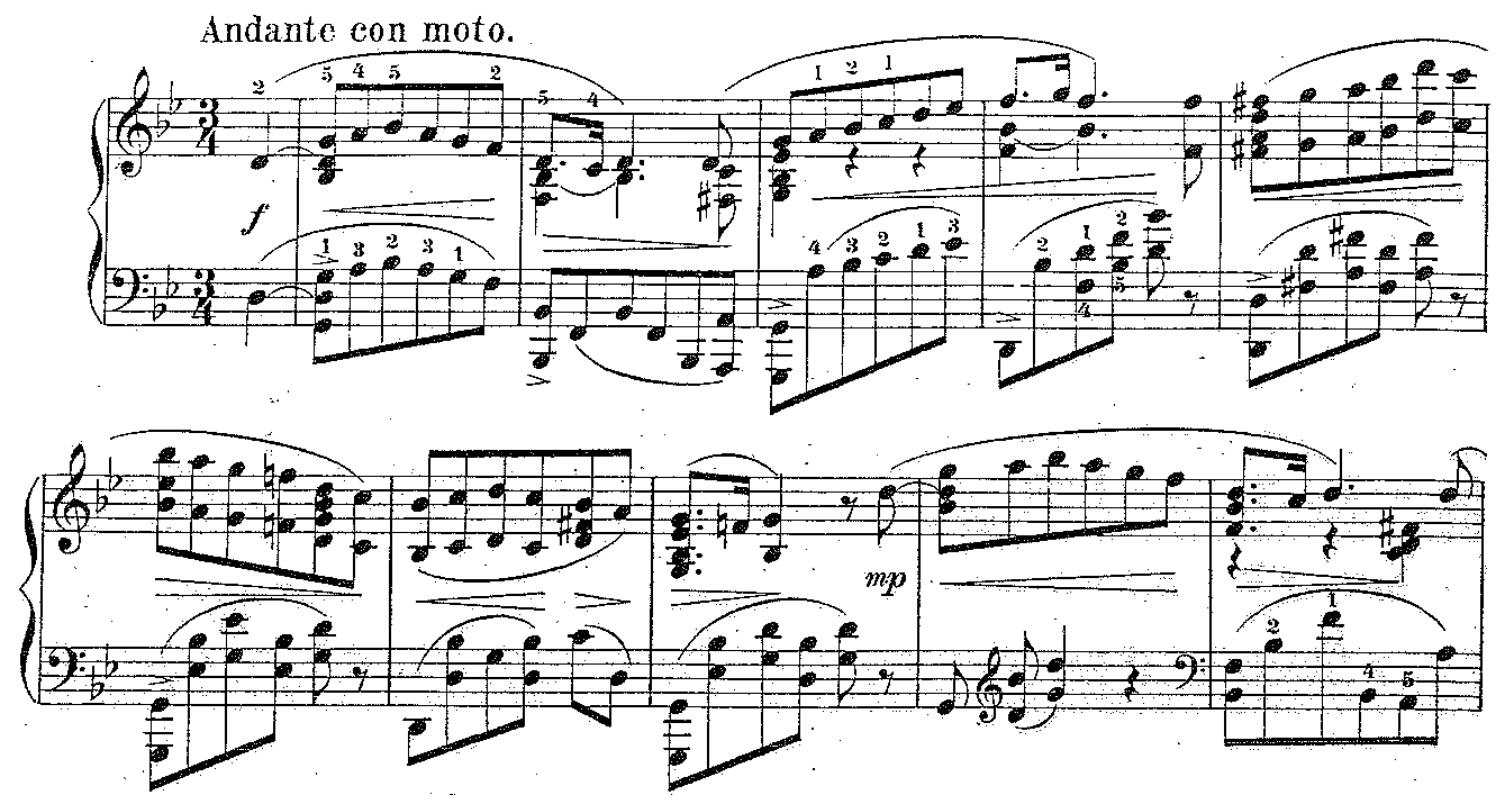

Example 5.4b Margaret Ruthven Lang: Petit Roman: Monsieur le Prince, op. 18 no. 4, mm. 1625

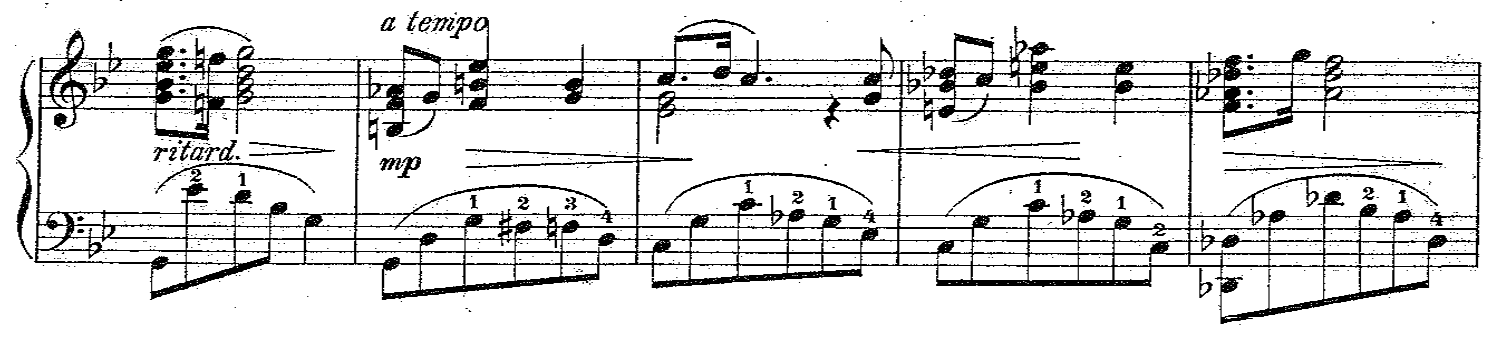




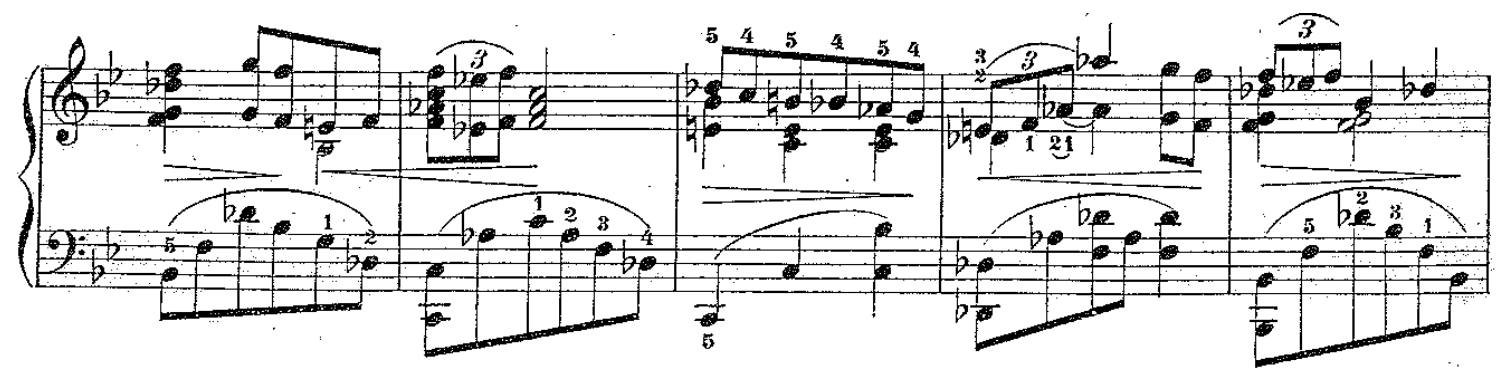

Lang underlays the theme of the $\mathrm{C}$ section with "The Prince thinks of the visit by the Knight to the home of Madame." The agitation of the prince is shown by the driving chords in constant eighth notes in the right hand, with the left-hand melody marked poco a poco agitato and crescendo poco a poco (example 5.4c).

Example 5.4c Margaret Ruthven Lang: Petit Roman: Monsieur le Prince, op. 18 no. 4, mm. 4150
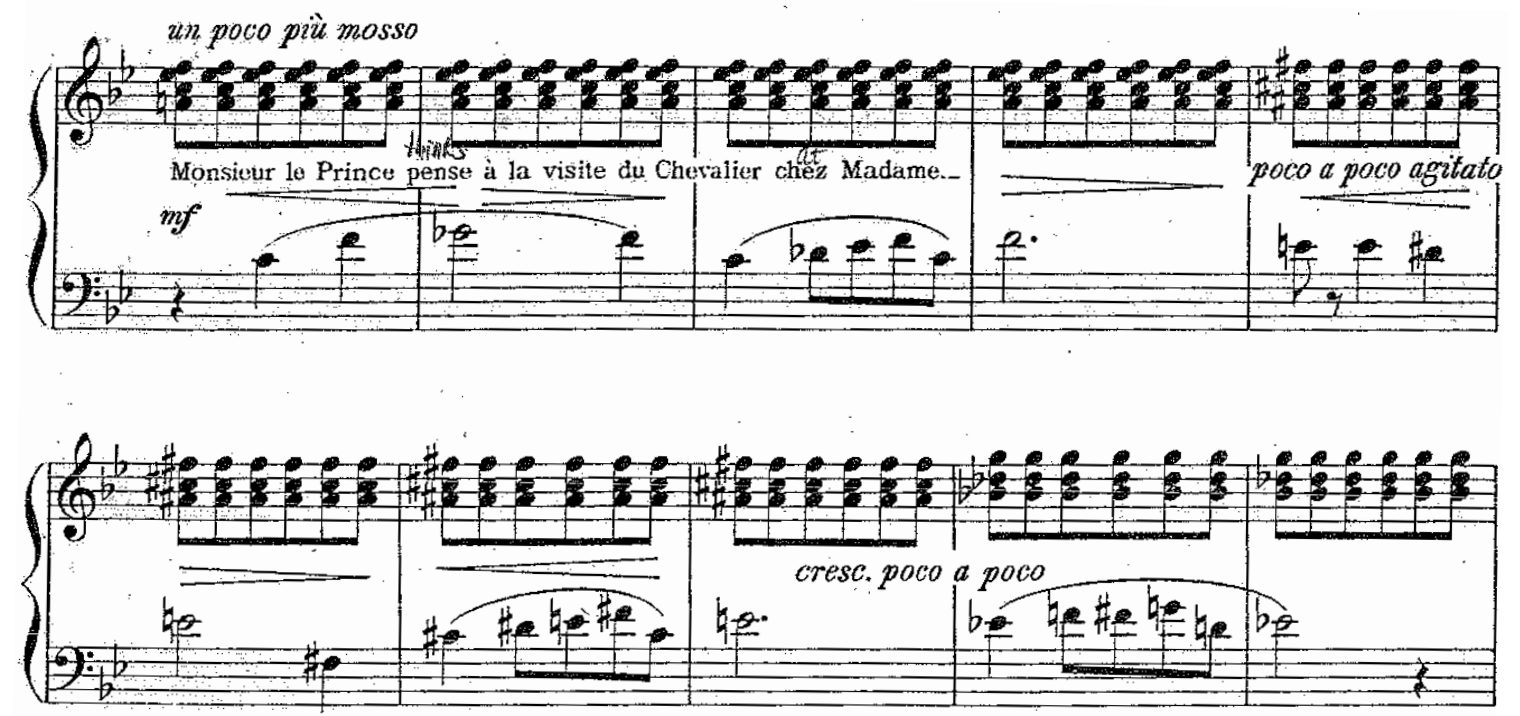

Later, the melody moves to right hand. The theme of this section is based on the theme that appears in the "La Princessa" mm. 37-44 (example 5.4d) 
Example 5.4d Margaret Ruthven Lang: Petit Roman: Monsieur le Prince, op. 18 no. 4, mm. $37-$ 44
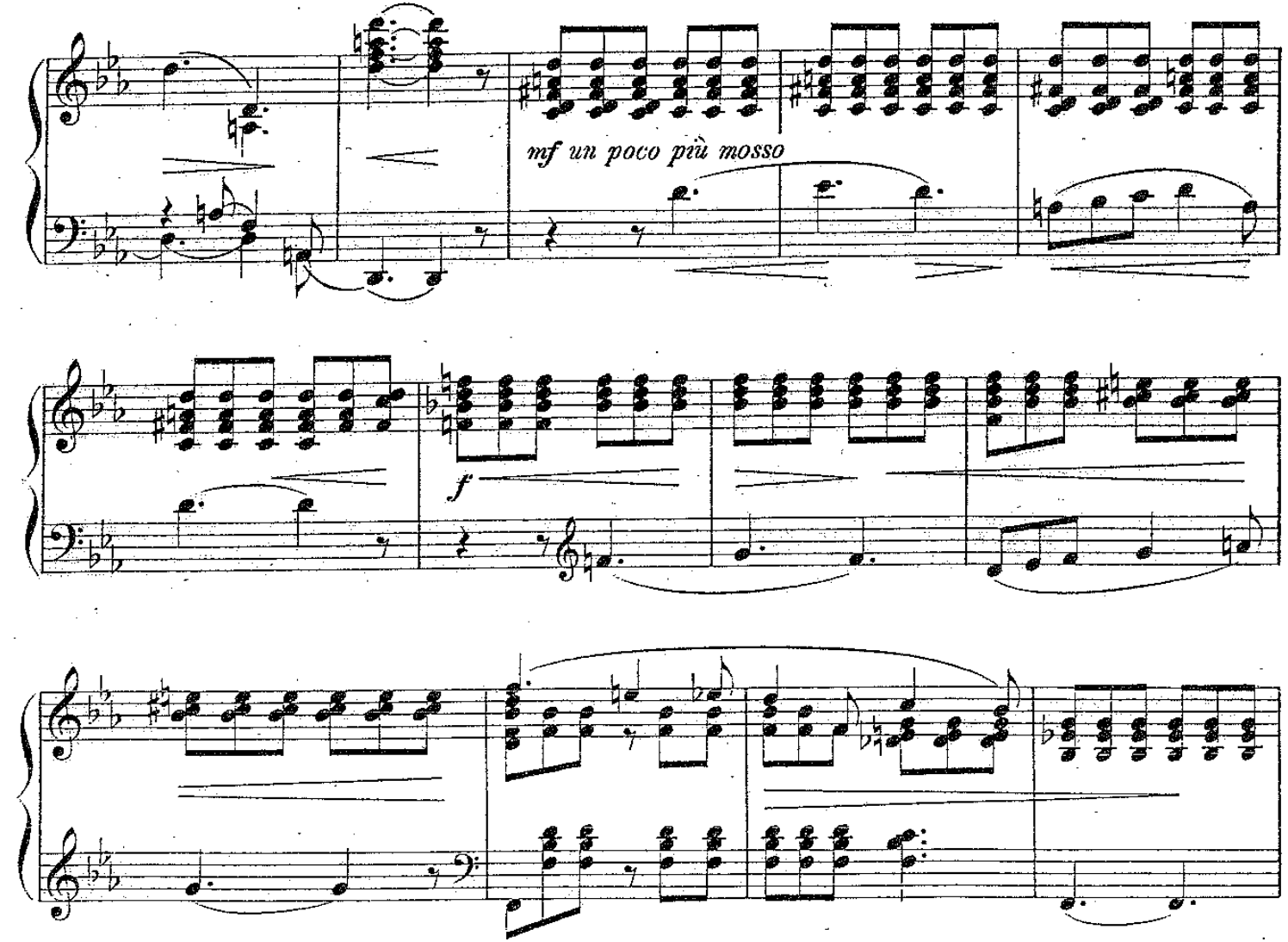

At last, the anger settles down somewhat, and a questioning feeling is reflected quietly in the coda of the B section (example 5.4e).

Example 5.4e Margaret Ruthven Lang: Petit Roman: Monsieur le Prince, op. 18 no. 4, mm. 61-74
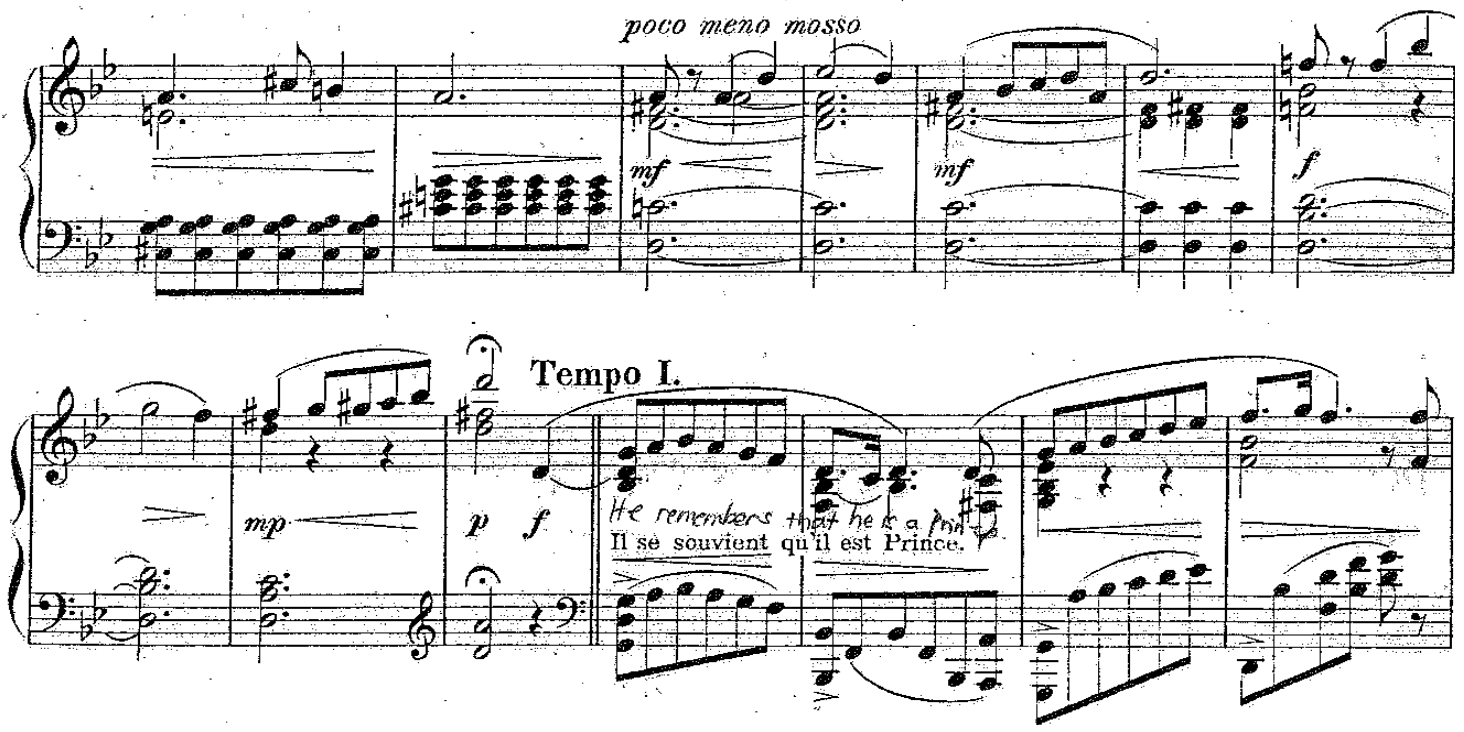
The theme of the A section, "He remembers that he is the Prince," returns (example above). The development of the first section builds to a climax of deep emotional intensity where the score says, "He thinks of vengeance." It returns in a shortened form of the previous coda - "He hesitates and thinks of Madame." Lang closes this movement with, "He hesitates no more" followed by sforzandi chords and a brief flurry of octaves marked crescendo accelerando which serve as a stirring ending as the Prince flees to find the Knight (example 5.4f).

Example 5.4f Margaret Ruthven Lang: Petit Roman: Monsieur le Prince, op. 18 no. 4, mm. 1-11
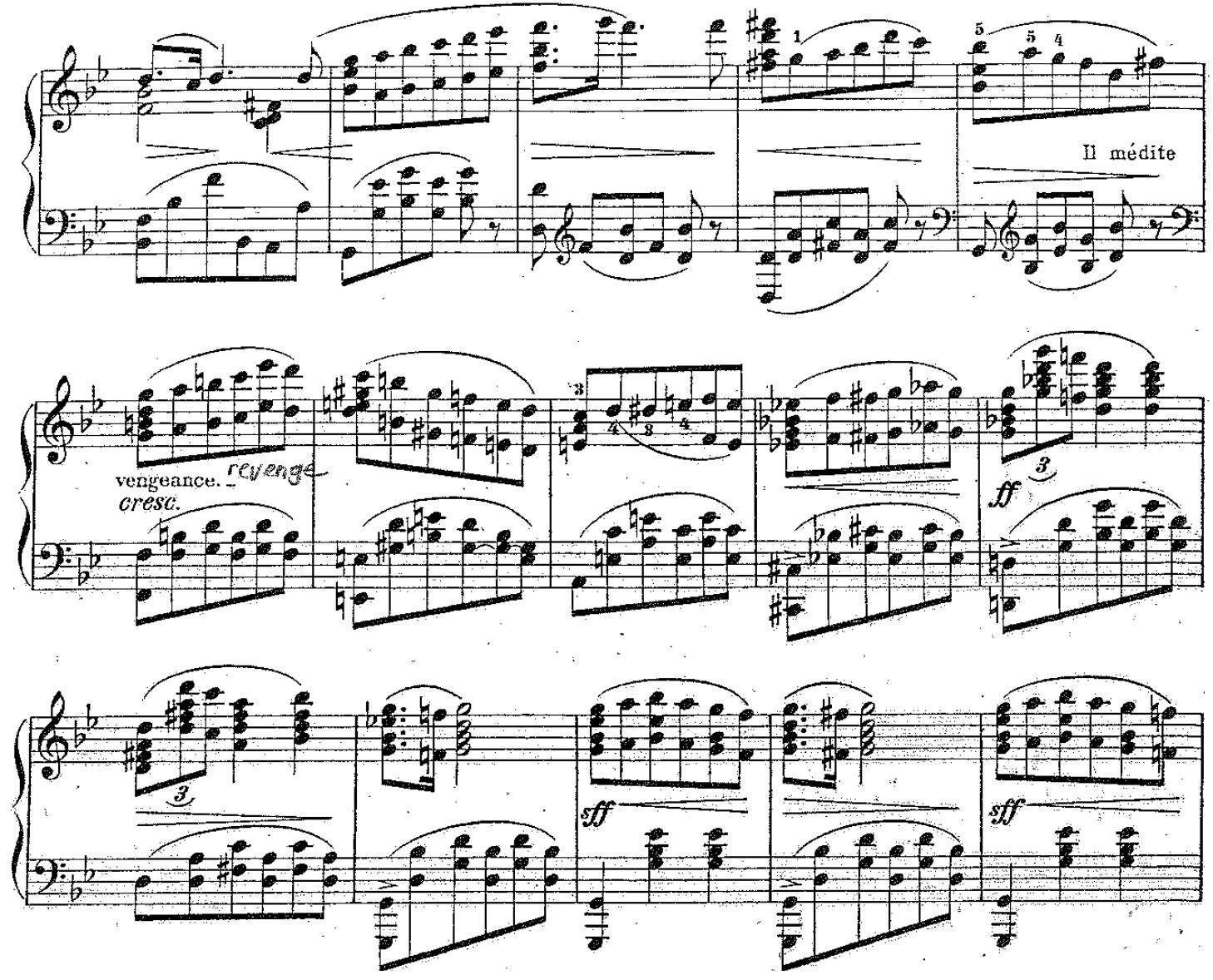

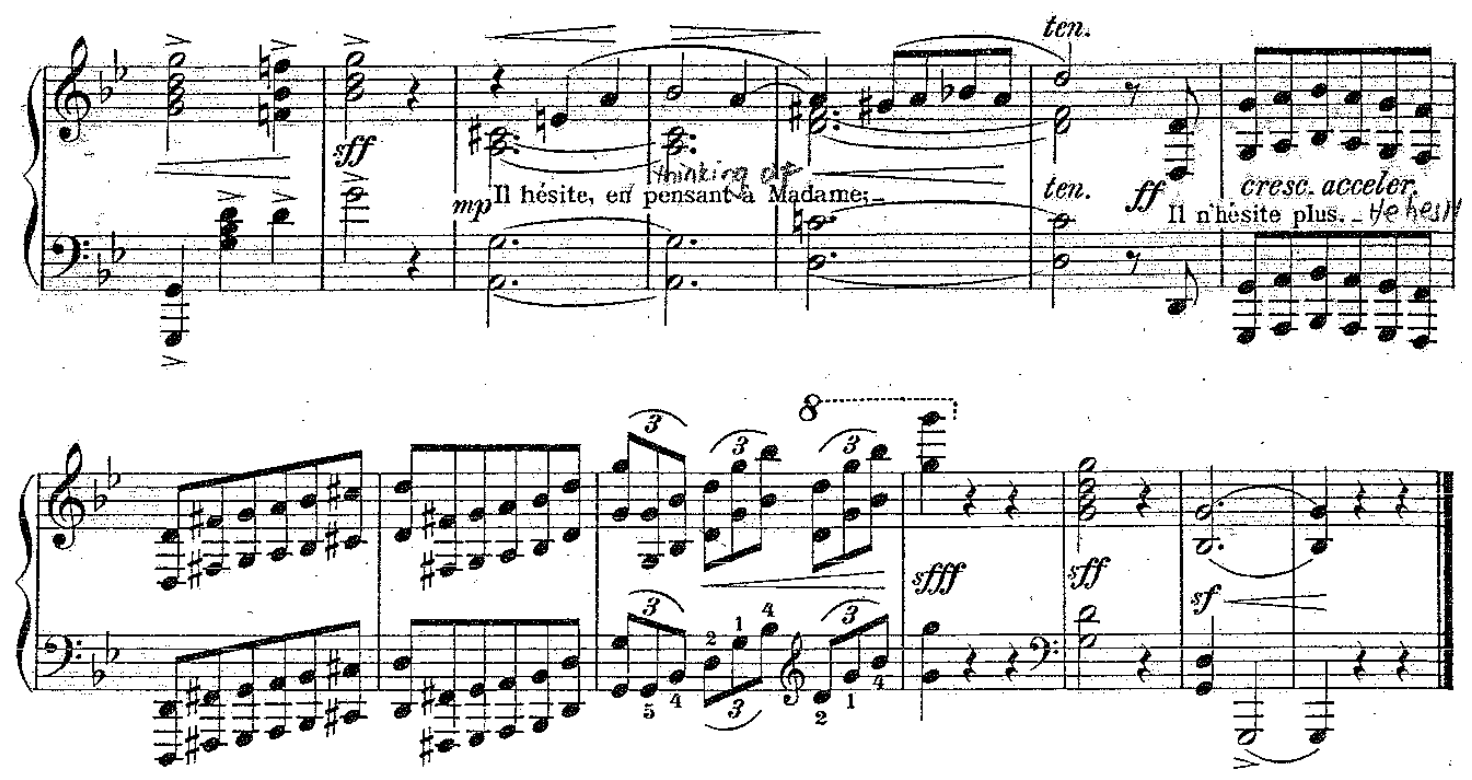

\section{L'Épée de Monsieur le Prince (The Prince's Sword)}

This movement is the duel between the Prince and the Knight. The scenario is one of vengeance contrasted with thoughts of love culminating with a dramatic end: the sword of the Prince finds the heart of the Knight. It is written in the bright key of B Major, a third away from the previous movement and in an ABA form. It opens with sforzandi accents, a running passage with both of the phrases ending with big chords marked sforzando and sforzatissimo, showing the anger of the Prince. The alternating octaves between the hands suggests the back and forth movements of the duel, and the scales the sweeping movement of the swords. Lang marks this first section Allegro con fuoco (example 5.5a). 
Example 5.5a Margaret Ruthven Lang: Petit Roman: L'Épée de Monsieur le Prince, op. 18 no. 5, mm. 1-6
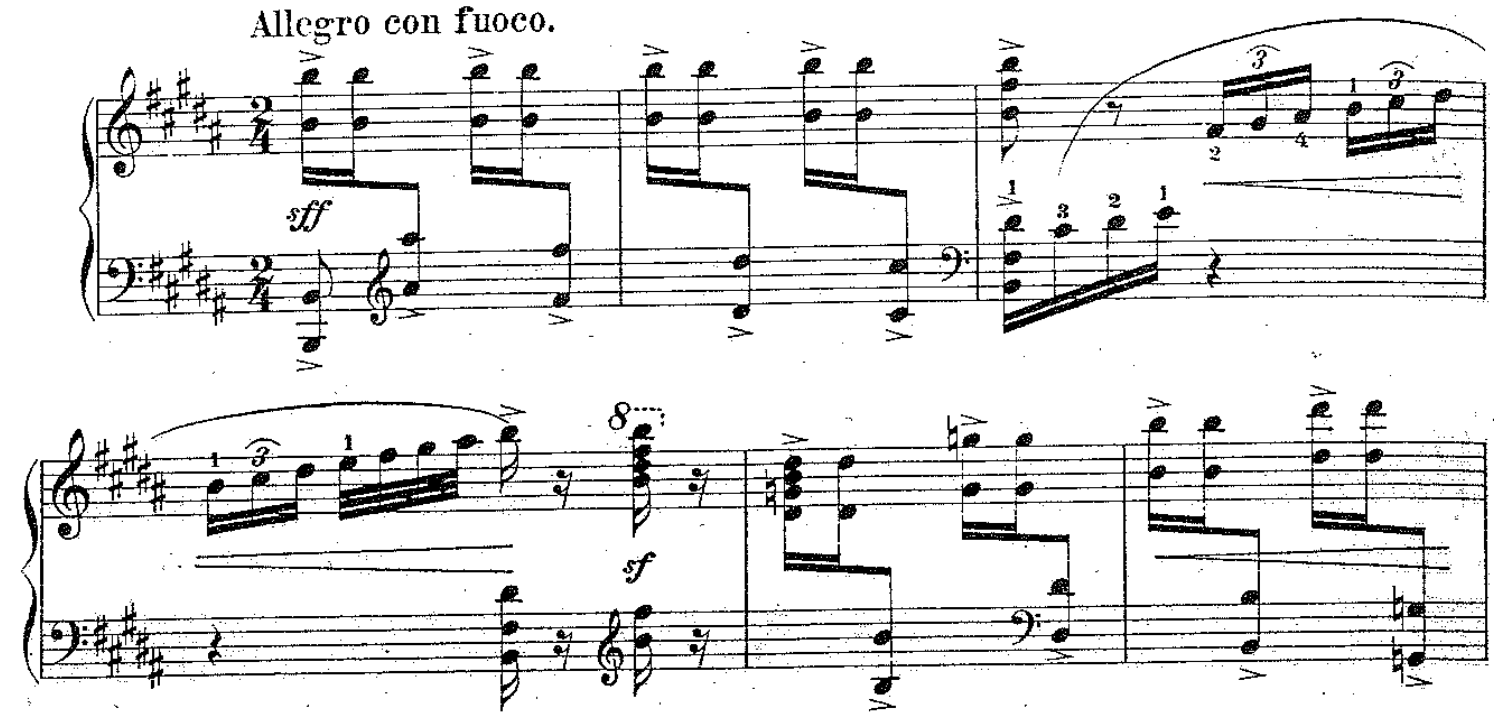

The second theme evokes imagery of sweet, good memories of the Princess, at a moment of break in the swordfight. It is written in the higher register and mostly marked pianissimo and mezzo piano (example 5.5b).

Example 5.5b Margaret Ruthven Lang: Petit Roman: L'Épée de Monsieur le Prince, op. 18 no. 5, mm. 33-38
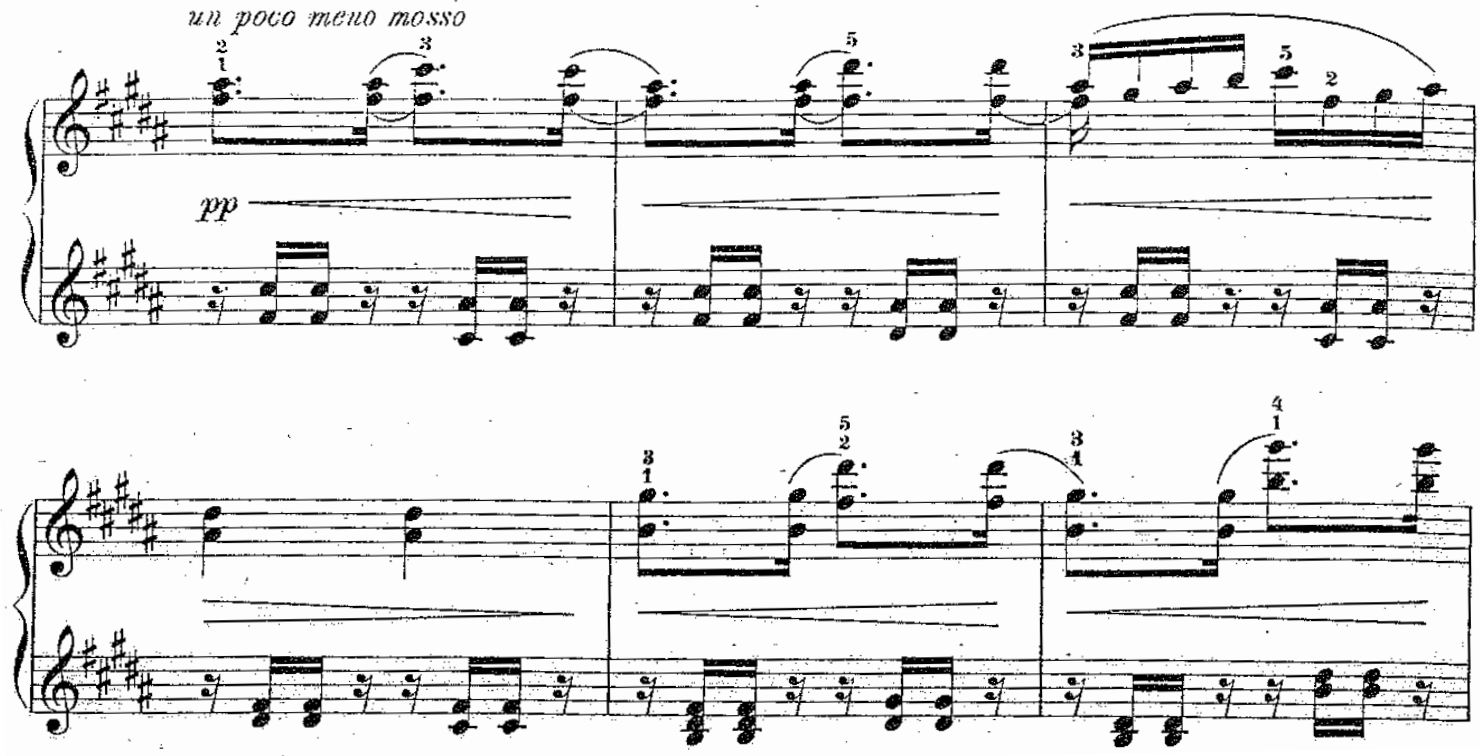
The last eight measures suggest a sense of urgency, as shown by the crescendo building up to sforzatissimo, and the recollection that he is the Prince is shown by the Maestoso section, the return of the theme from the previous movement, marked forte (example 5.5c).

Example 5.5c Margaret Ruthven Lang: Petit Roman: L’Épée de Monsieur le Prince, op. 18 no. 5, mm. $45-55$
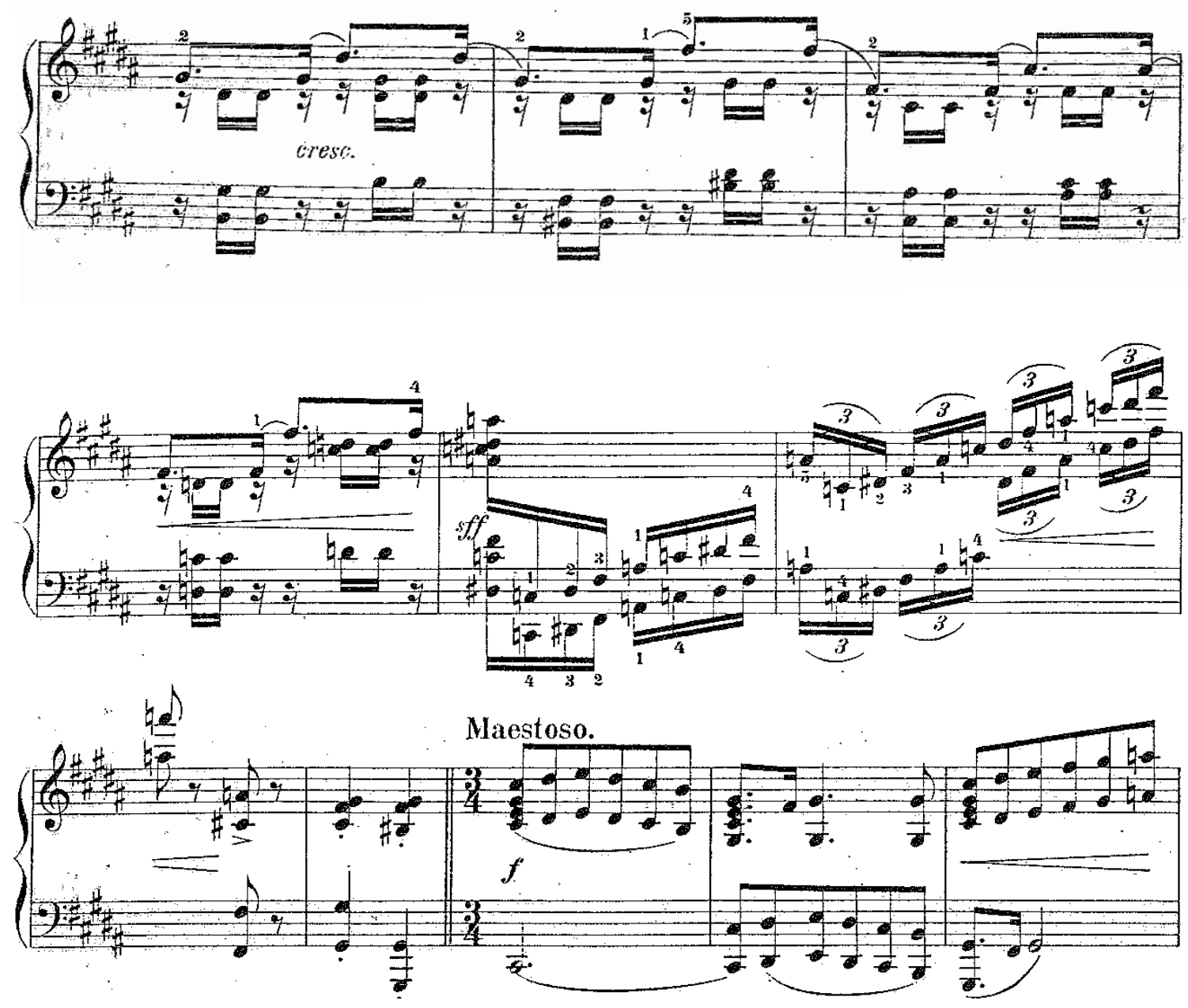

The return of the A section is followed by fragments of themes from the B section. Later, the marking "Revenge" appears for the first time. Lang shows "Love" using the same tune as "He speaks of love" from movement one, Le Chevalier. Later, Lang writes the "sword of the Prince finds the heart of the Knight," marked by the dramatic tremolo. The triplet sixteenth notes create a driving force that achieves 
considerable momentum and the movement ends with two triumphal chords (example

$5.5 \mathrm{~d})$.

Example 5.5d Margaret Ruthven Lang: Petit Roman: L'Épée de Monsieur le Prince, op. 18 no. 5, mm. 93-114
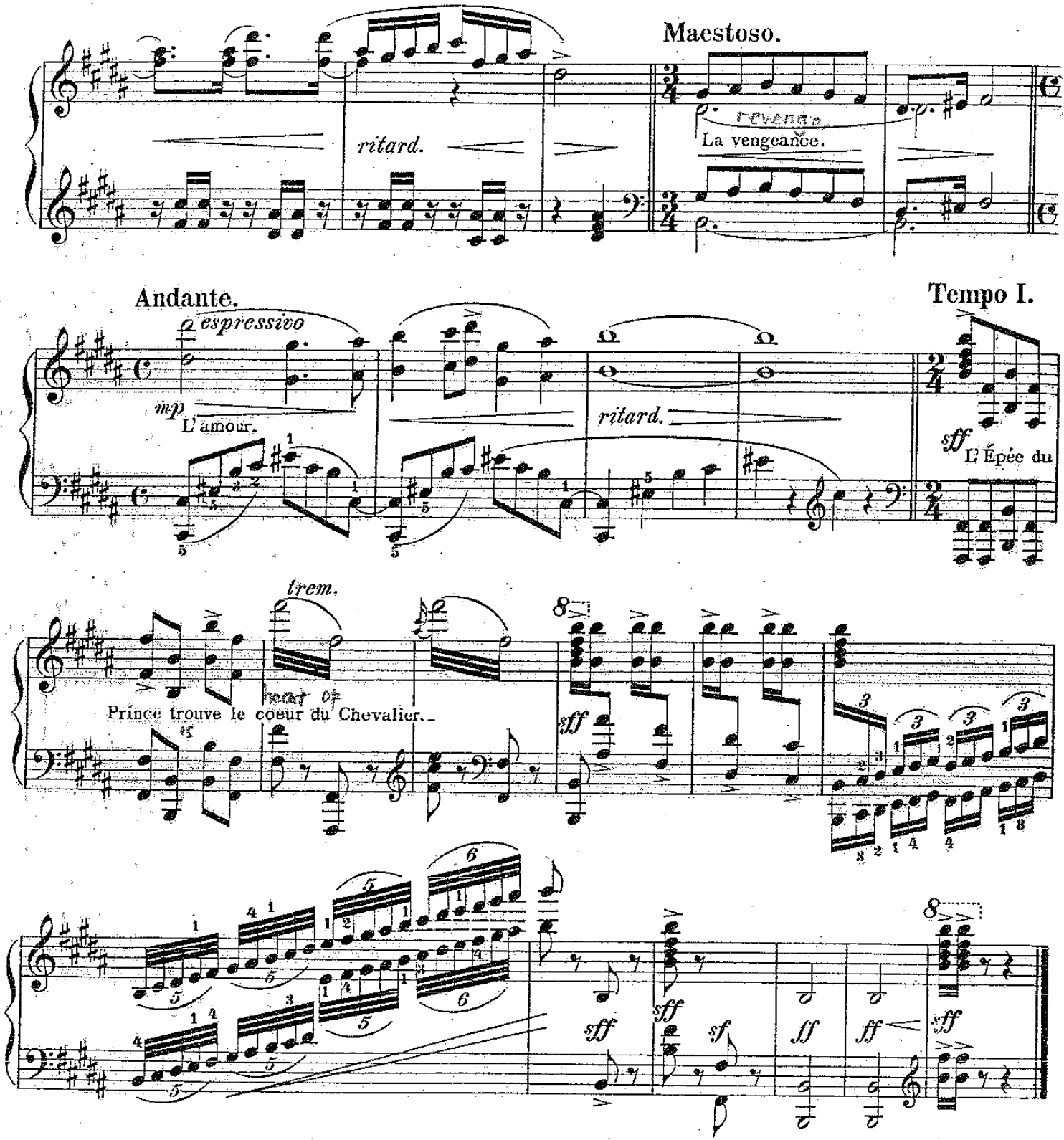


\section{La mort du Chevalier (The Death of the Knight)}

In the final movement the Knight is dying, and he think of his love for the Princess and of her charms. He remembers the ball and then the Prince. Later, he thinks of the sword that wounded him; he calls out his love and he dies. This last piece, the shortest of the group, is exceptionally beautiful. Lang successfully recaptures all of the themes using essentially the same material in the form of memories as the Chevalier dies. The entire composition grows out of motivic materials presented in the previous movements.

The movement begins with a four-measure introduction before the entrance of the main theme, which is based on the introduction motive of Madame la Princesse (example 5.6a).

Example 5.6a Margaret Ruthven Lang: Petit Roman: Madame la Princesse, op. 18 no. 2, mm. 1-4

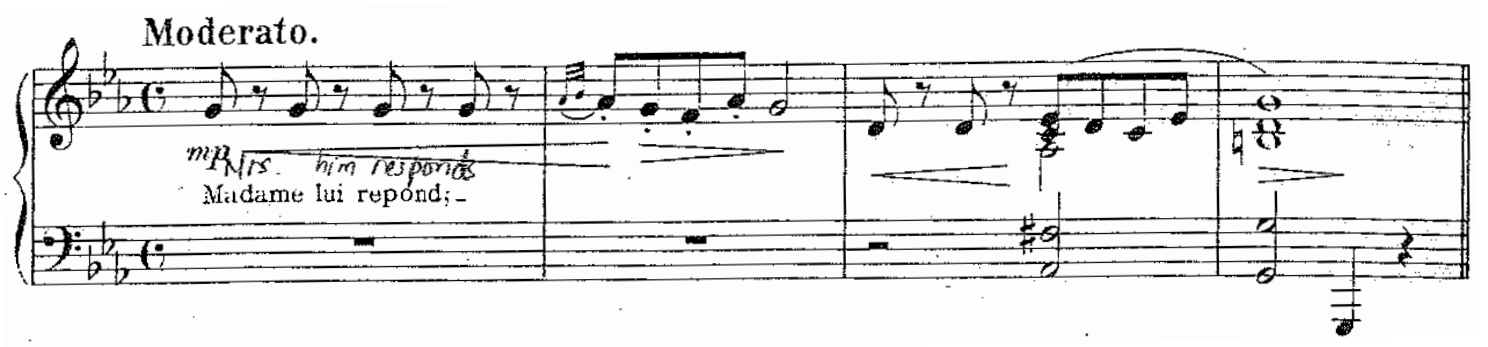

Example 5.6b Margaret Ruthven Lang: Petit Roman: La Mort du Chevalier, op. 18 no. 6, mm. 14


The rhapsodic theme of Le Chevalier, when he "speaks of love," is recaptured by Lang to show when "the Knight is dying and he thinks of his love for the Princess" (example 5.6c). 
Example 5.6c Margaret Ruthven Lang: Petit Roman: Le Chevalier, op. 18 no. 1, mm. 40-42

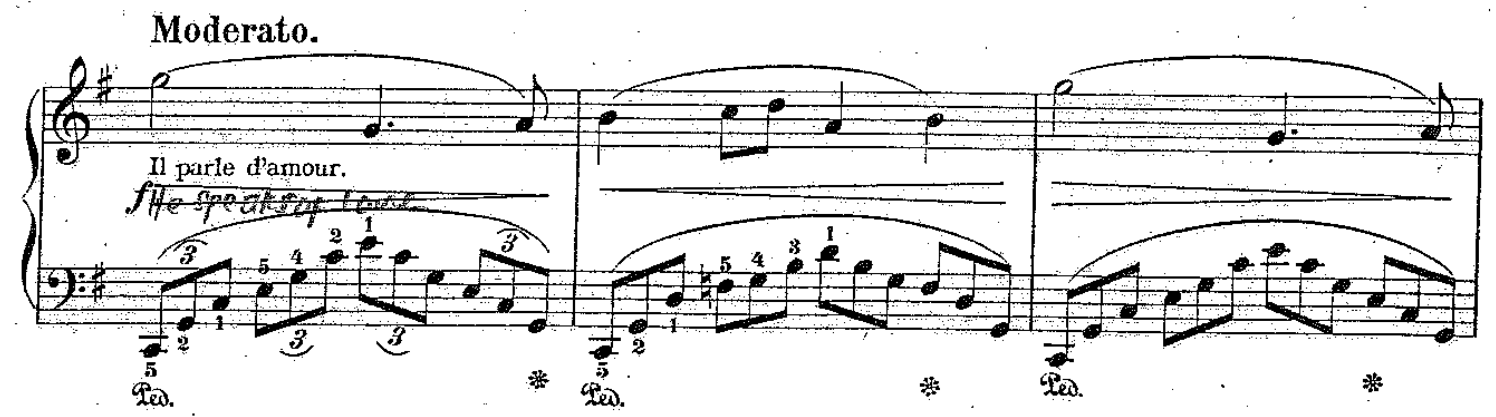

Example 5.6d Margaret Ruthven Lang: Petit Roman: La Mort du Chevalier, op. 18 no. 6, mm. 47

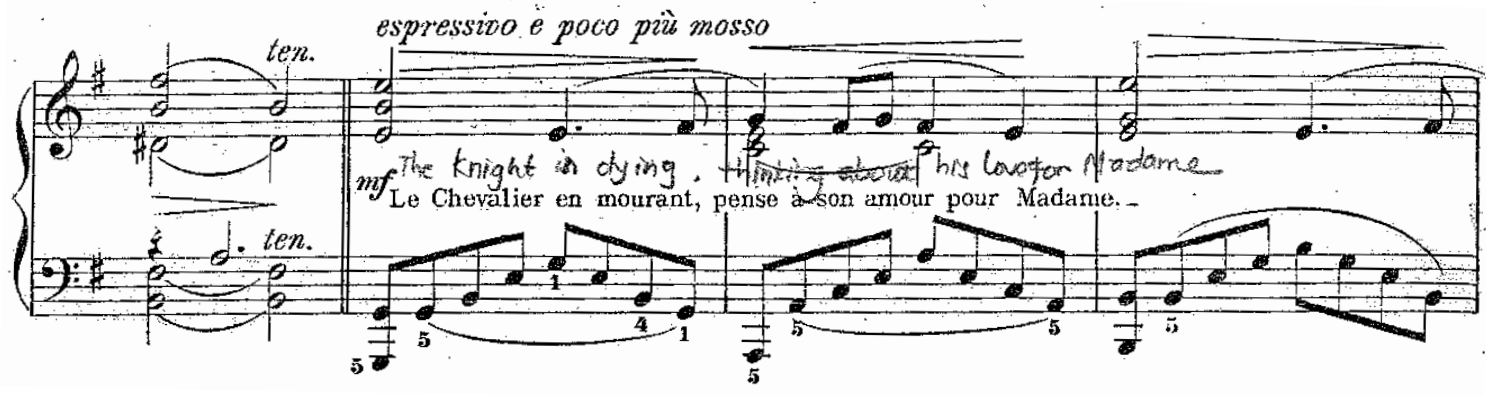

As the Knight thinks of his love for the Princess, he also thinks of "her charms." Lang expresses this through the theme that she adapts from the passage marked "She acts indifferently" (example 5.6e).

Example 5.6e Margaret Ruthven Lang: Petit Roman: La Princesse, op. 18 no. 2, mm. 5-9

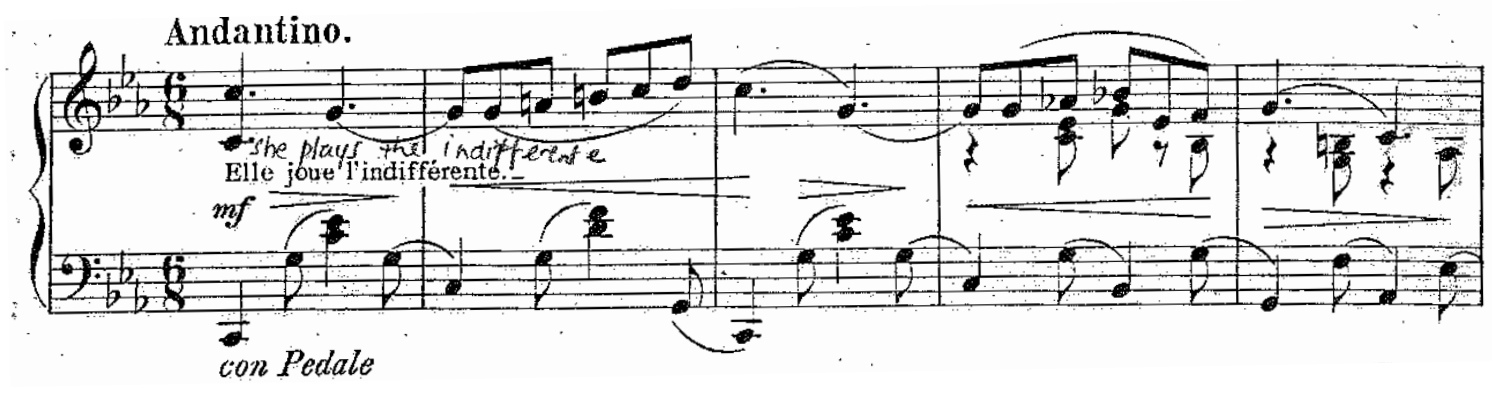


Example 5.6f Margaret Ruthven Lang: Petit Roman: La Mort du Chevalier, op. 18 no. 6, mm. 47
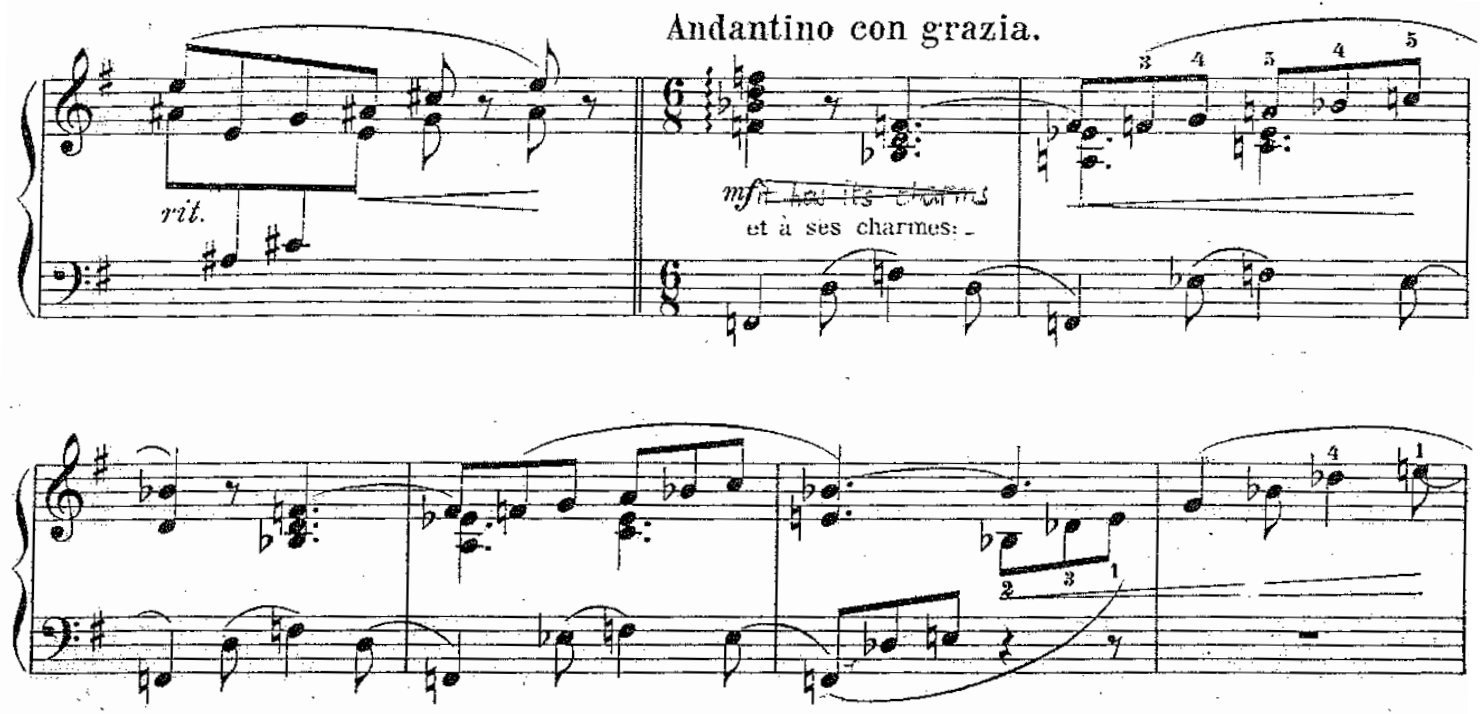

"He remembers the ball" recalls the theme from movement three, con grazia e

delicatezza (example 5.6g).

Example 5.6g Margaret Ruthven Lang: Petit Roman: Bal chez Madame la Princesse, op. 18 no. $3, \mathrm{~mm} .83-88$

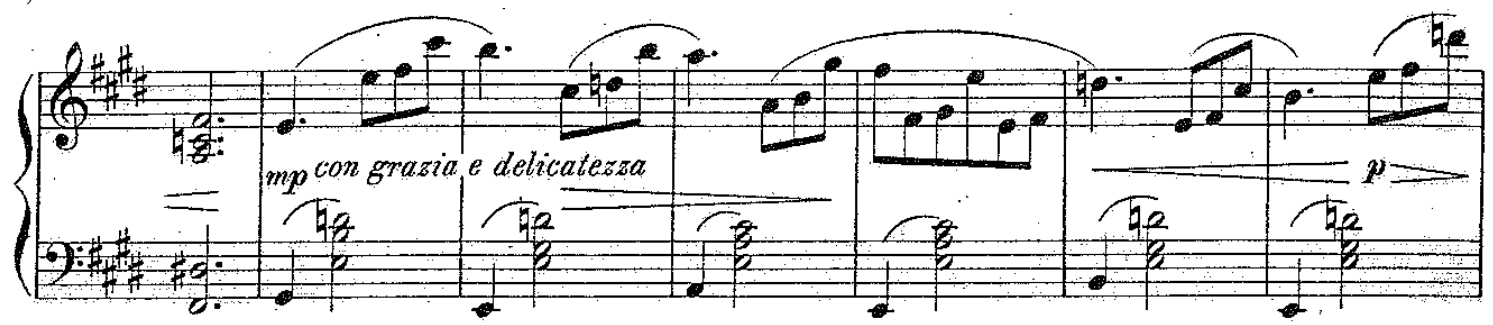

Example 5.6h Margaret Ruthven Lang: Petit Roman: La Mort du Chevalier, op. 18 no. 6, mm. 47

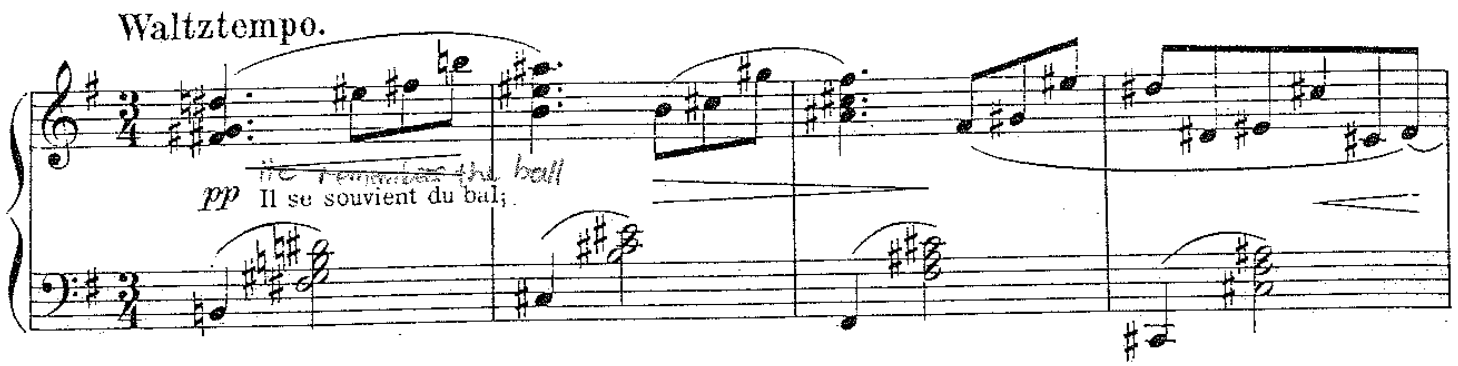


After recalling those sweet memories, he thinks of the Prince. Lang reuses the material from the introduction of this movement, which is also the introduction to the passage from La Princesse in which the Princess responds combined with La Mort du Chevalier (example 5.6i)

Example 5.6i Margaret Ruthven Lang: Petit Roman: Monsieur le Prince, op. 18 no. 4, mm. 1-4

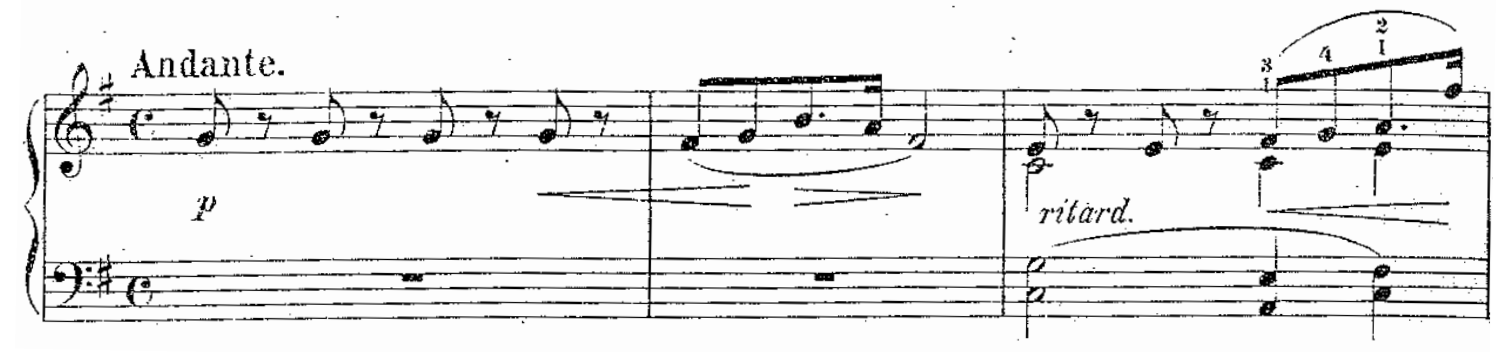

Example 5.6j Margaret Ruthven Lang: Petit Roman: La Mort du Chevalier, op. 18 no. 6, mm. $47-51$
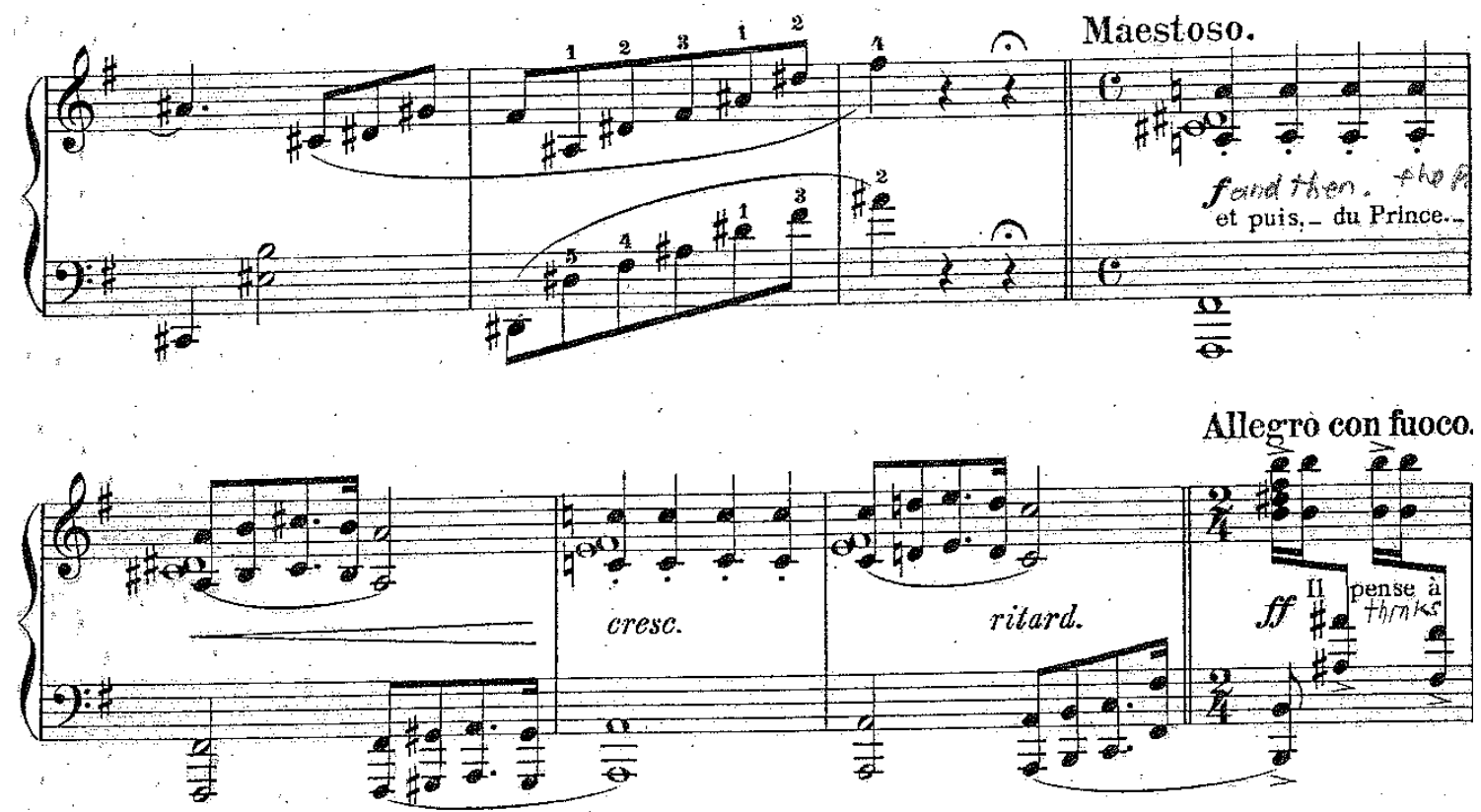

"He thinks of the sword that caused his death" is shown by the duel theme from L'Épée de Monsieur le Prince (example 5.6k). 
Example 5.6k Margaret Ruthven Lang: Petit Roman: L’Épée de Monsieur le Prince, op. 18 no. $5, \mathrm{~mm} .1-6$

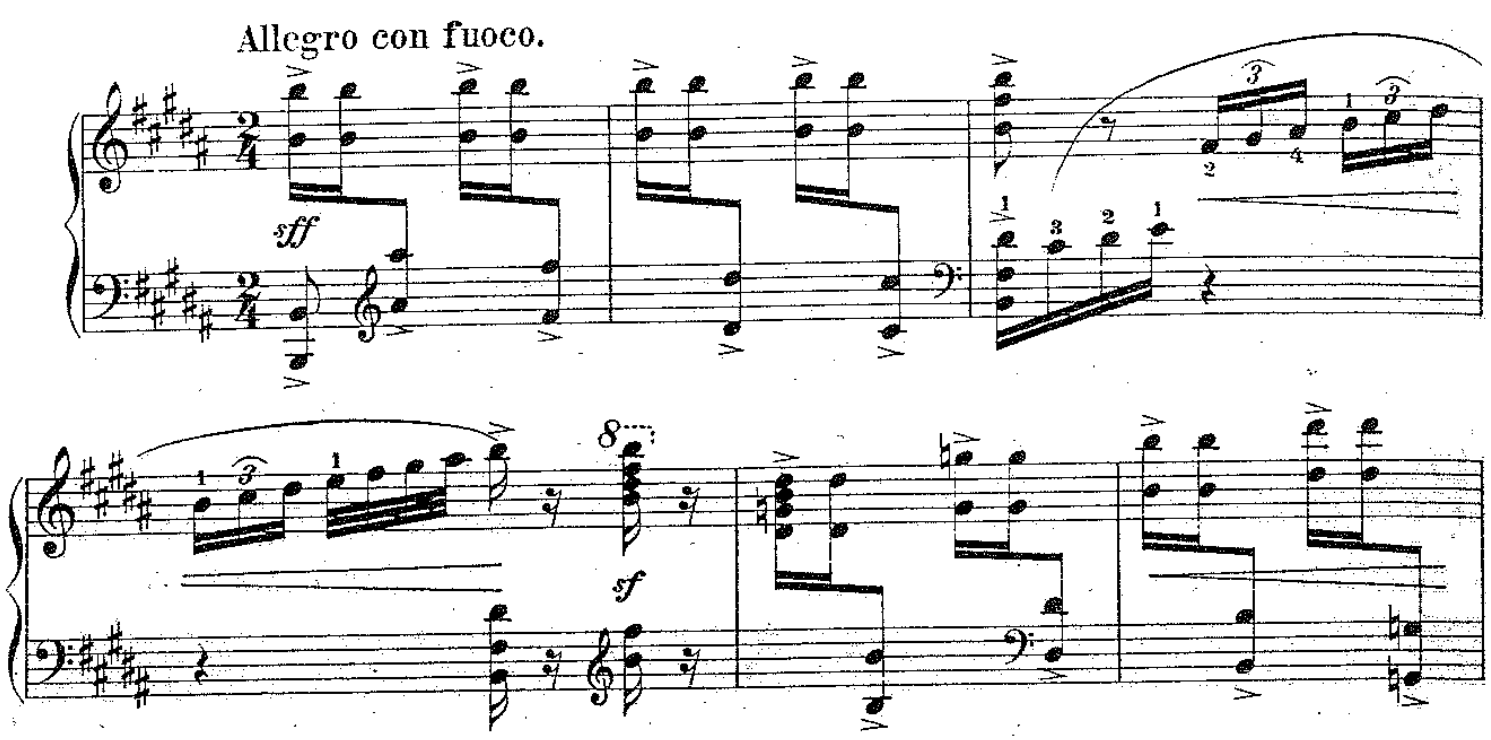

Example 5.61 Margaret Ruthven Lang: Petit Roman: La Mort du Chevalier, op. 18 no. 6, mm. $47-51$
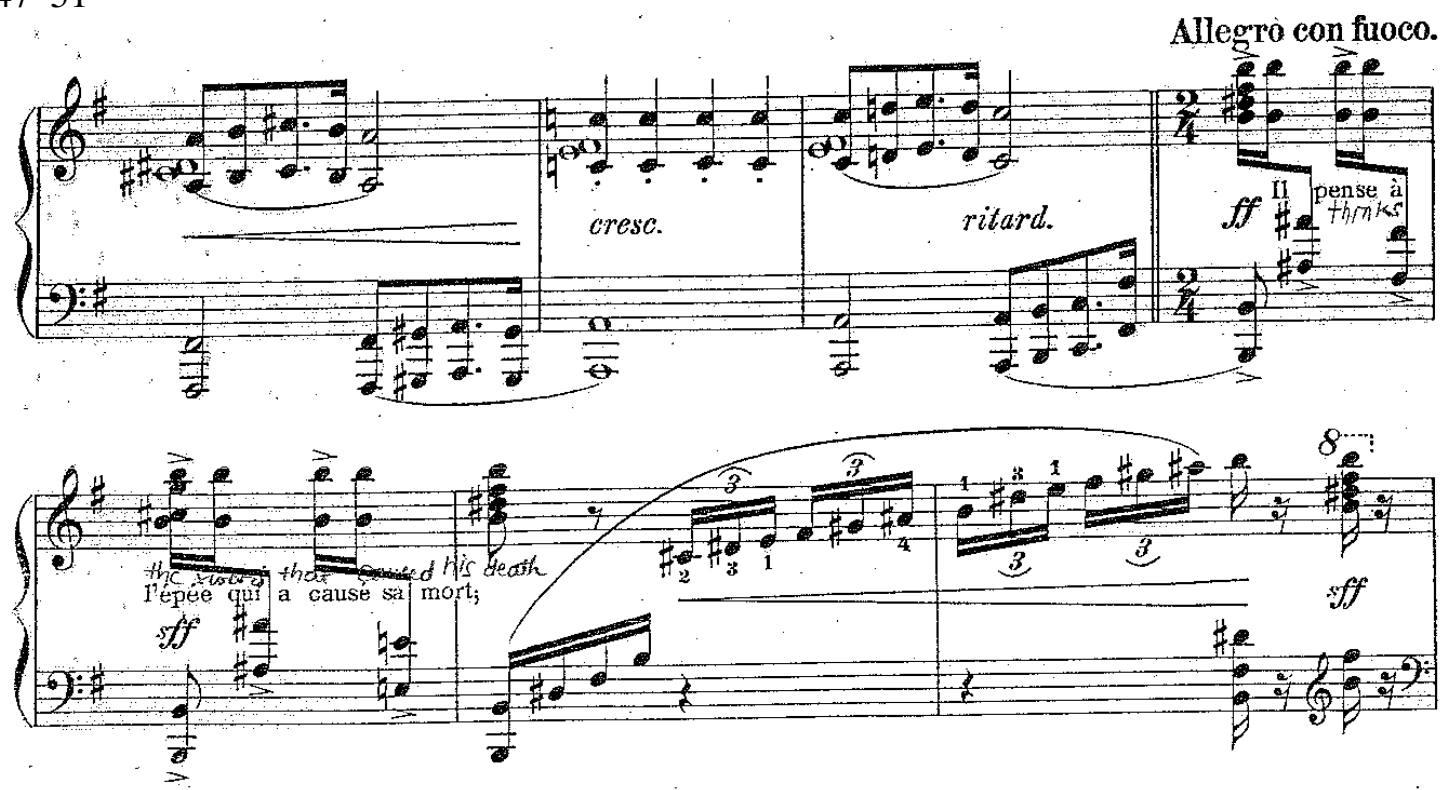

"The Knight is dying and he calls out his love": for the last time, Lang reuses the rhapsodic theme from the first movement, Le Chevalier, when he speaks of love (example 5.6m) 
Example 5.6m Margaret Ruthven Lang: Petit Roman: Le Chevalier, op. 18 no. 1, mm. 40-42

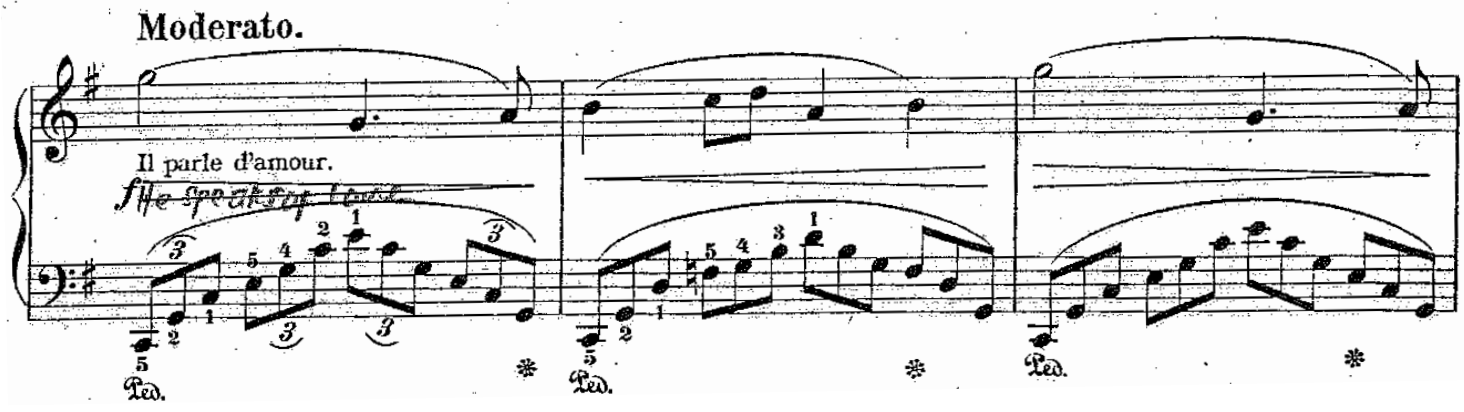

Example 5.6n Margaret Ruthven Lang: Petit Roman: La Mort du Chevalier, op. 18 no. 6, mm. $47-51$
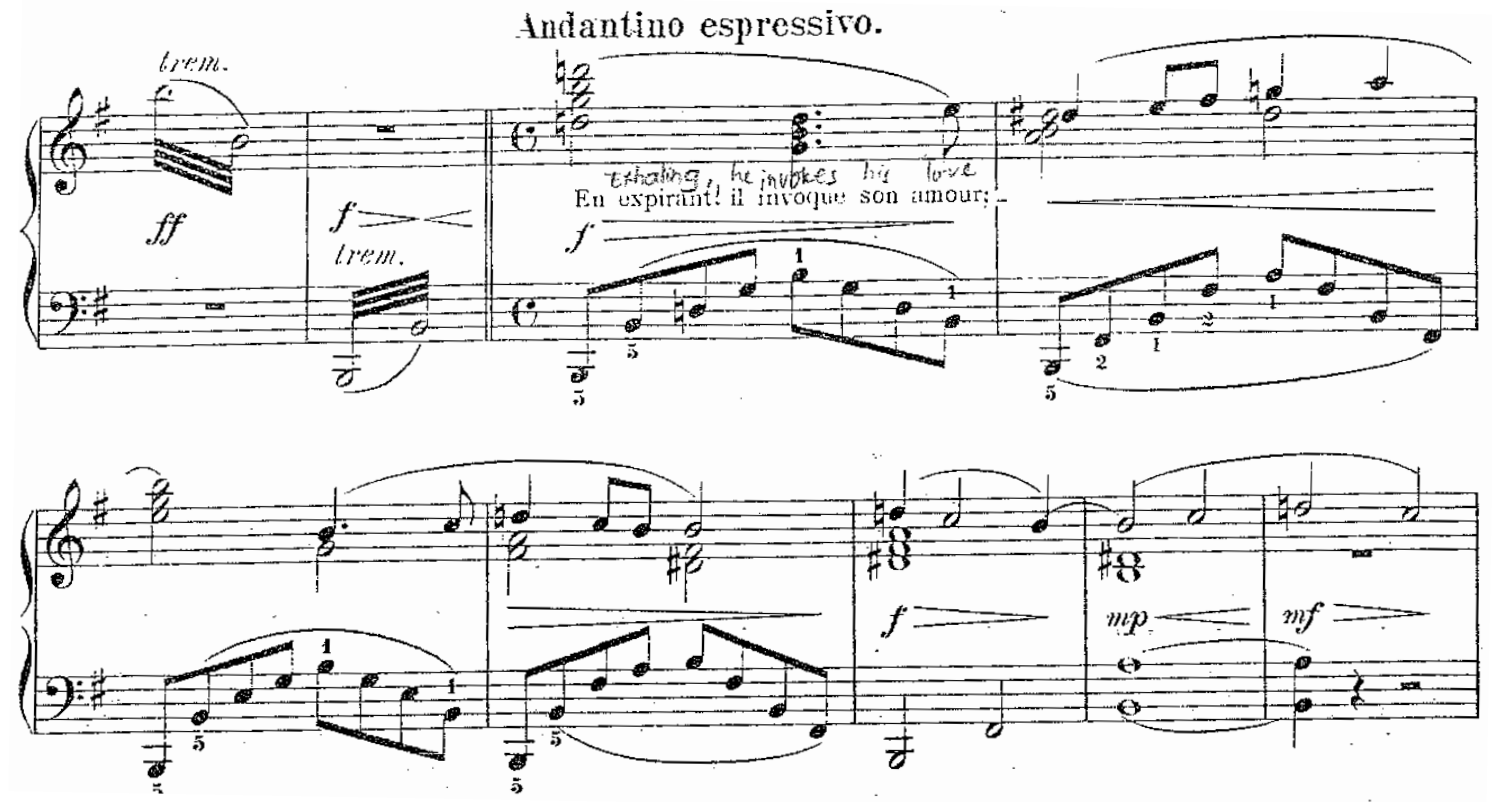

The ending of the tragic love story comes when the Knight dies. The story closes with material from the fourth movement modified so as to be marked grave. Lang creates the ending as in the style of a funerailles (example 5.60).

Example 5.6o Margaret Ruthven Lang: Petit Roman: La Mort du Chevalier, op. 18 no. 6, mm. $47-51$

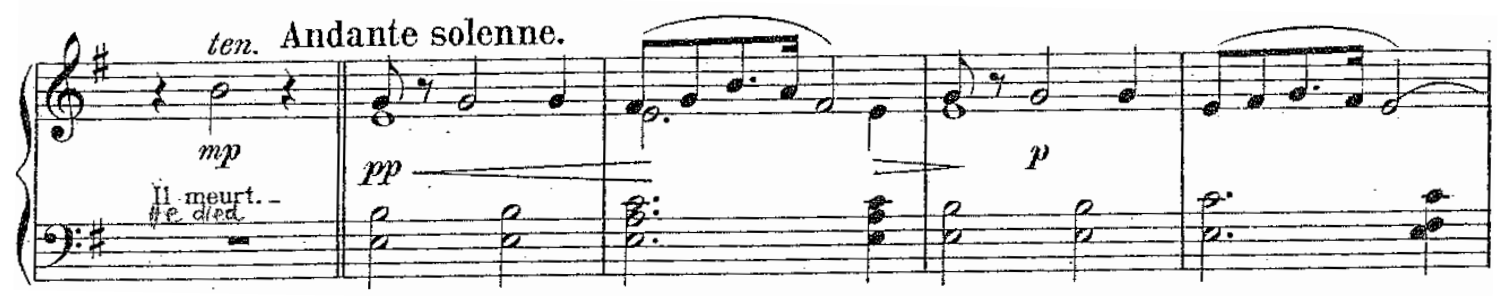




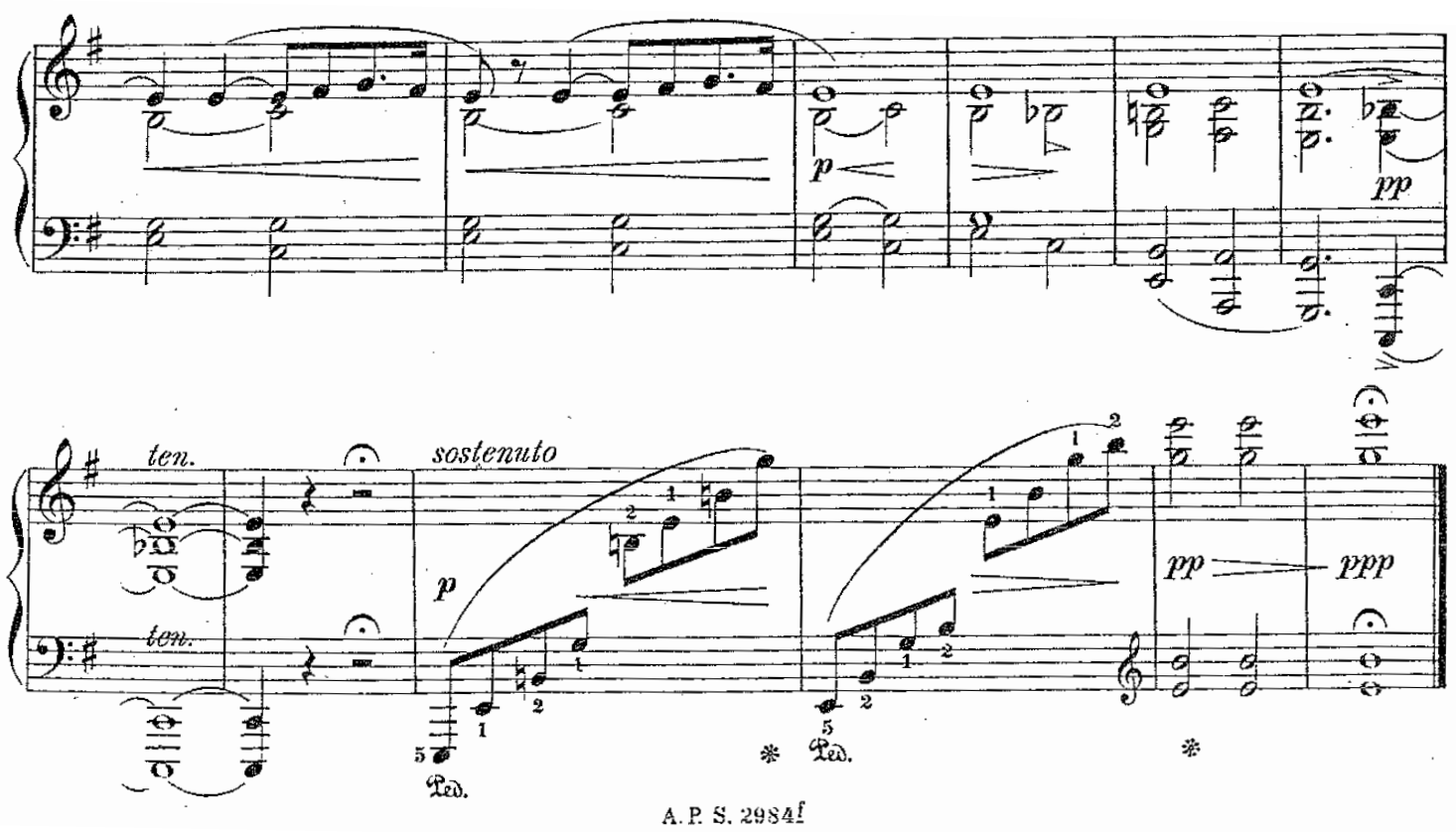

The piece starts and ends in e minor; notwithstanding, the keys and the time

signatures of the sections change as the memories from the previous movements are mentioned.

Recorded performances of Petit Roman are as follows:

- "This December 1st. performance of Petit Roman was less than a month after its premier which was given by Mrs. Edward Dudley Marsh at the November 6, 1894 meeting of the 'Tuesday Musicale' of Rochester, N.Y. --a note in the program mentions that Margaret wrote both the music and the story." 52

- "A concert in Boston on Saturday, December 1 at 11AM presented by Miss Orvis as part of her 'Concerts for Young People' (five per season) included B. J. Lang playing Petit Roman followed by six of the Nonsense Rhymes (Filey, Man Cape Horn, Man Skye, When Little, Said Well, and Riga) sung."

- "Others quickly learned the work--Miss Mary Black included it in her program at Chickering Hall on December 18, 1894.",54

\footnotetext{
${ }^{52}$ Johnston, "Margaret Ruthven Lang \& Family: 1893-1925" http://www.margaretruthvenlang.com (accessed January 29, 2013).

${ }^{53}$ James Johnston, "Margaret Ruthven Lang \& Family: People and Places" http://www.margaretruthvenlang.com (accessed January 29, 2013).

${ }^{54}$ James Johnston, "Margaret Ruthven Lang \& Family: People and Places" http://www.margaretruthvenlang.com (accessed January 29, 2013).
} 


\section{CHAPTER VI}

\section{RHAPSODY, OP. 21}

Lang composed her fourth piano work, Rhapsody in e minor, op. 21 in 1895, a year after she wrote the collection Petit Roman. Rhapsody was published in 1895 by Schmidt and was also re-issued by Hildegard Publishing Company in 1990, in a new collection titled American Women Composers: Piano Music from 1865-1915, edited by Sylvia Glickman.

Rhapsody is one of two compositions that do not bear a descriptive title; the other is Rondoletto, op. 60 no. 3. Nonetheless, Lang exemplifies the Romantic impulse by drawing inspiration from the literary world, here with lines by Victor Hugo, which she includes in the piano score. Below is the poem along with the English translation:

Puisqu'ici-bas tout âme

Donne à quelqu'un

Sa musique, sa flamme,

Ou son parfum;

Je tedonne à cetteheure, Penché sur toi La chose la meilleure Quej'aie en moi!
Since here below each soul

Gives to someone, His music, his fervor, Or his scent;

I give you at this hour Leaning over you The best thing That I have in me!

Victor-Marie Hugo (February 26, 1802 - May 22, 1885), novelist, poet, painter, and statesman, is recognized as one of the most influential Romantic writers of the nineteenth century. Hugo's beautiful writing has attracted an exceptional amount of interest from musicians, who have composed numerous melodies based on his poetry. 
Composers inspired by Hugo include Berlioz, Liszt, Bizet, Fauré, Franck, Lalo, Massenet, Saint-Saëns, Rachmaninov, Wagner, and Lang. ${ }^{55}$

Lang tries to capture the two stanzas of Hugo's poem by casting her composition in an $\mathrm{AB}$ form followed by a coda with added contrast. The form is traditional yet purposefully improvisational, as the title itself suggests. Structurally, this 112-measure piece exhibits various arrangements of section blocks. They are often disguised in their returning form by considerable alteration in settings: additional passage work, reworked supporting harmony, modulation to new keys, and new accompaniments. These refashionings are frequently so intricate that the introduction of new thematic material is minimal, as enough contrast and interest occurs by the repetition of the subject in its new guise. Contrapuntal writing is not present, and a traditional structure, such as binary, ternary, or rondo form, is absent. Glickman writes in the introduction to American Women Composers, "Rhapsody is a moderately long, complicated piece, filled with rich chromaticism and romantic pianistic gestures."

The tempo marking of this piece is Maestoso. The first stanza of Hugo's poem demonstrates an outpouring of heartfelt emotion. Lang uses the key of e minor and is able to successfully heighten the harmonic interest by extended and chromatic harmonies. Rhapsody starts with a theme in a broad e minor chord that covers four octaves marked fortissimo that leads to fortississimo in measure five and sforzatissimo in measure six. This heroic opening is poised, poetic, and played boldly and vigorously (example 6.1).

\footnotetext{
${ }^{55}$ New World Encyclopedia contributors, "Victor Hugo," New World Encyclopedia, http://www.newworldencyclopedia.org/p/index.php?title=Victor_Hugo\&oldid=794680 (accessed February 18, 2013).

${ }^{56}$ Sylvia Glickman, American Woman Composers: Piano Music from 1865-1915 (Bryn Mawr: Hildegard Publishing Company, 1990), 3.
} 
Example 6.1 Margaret Ruthven Lang: Rhapsody, op. 21, mm. 1-7

\section{RHAPSODY.}

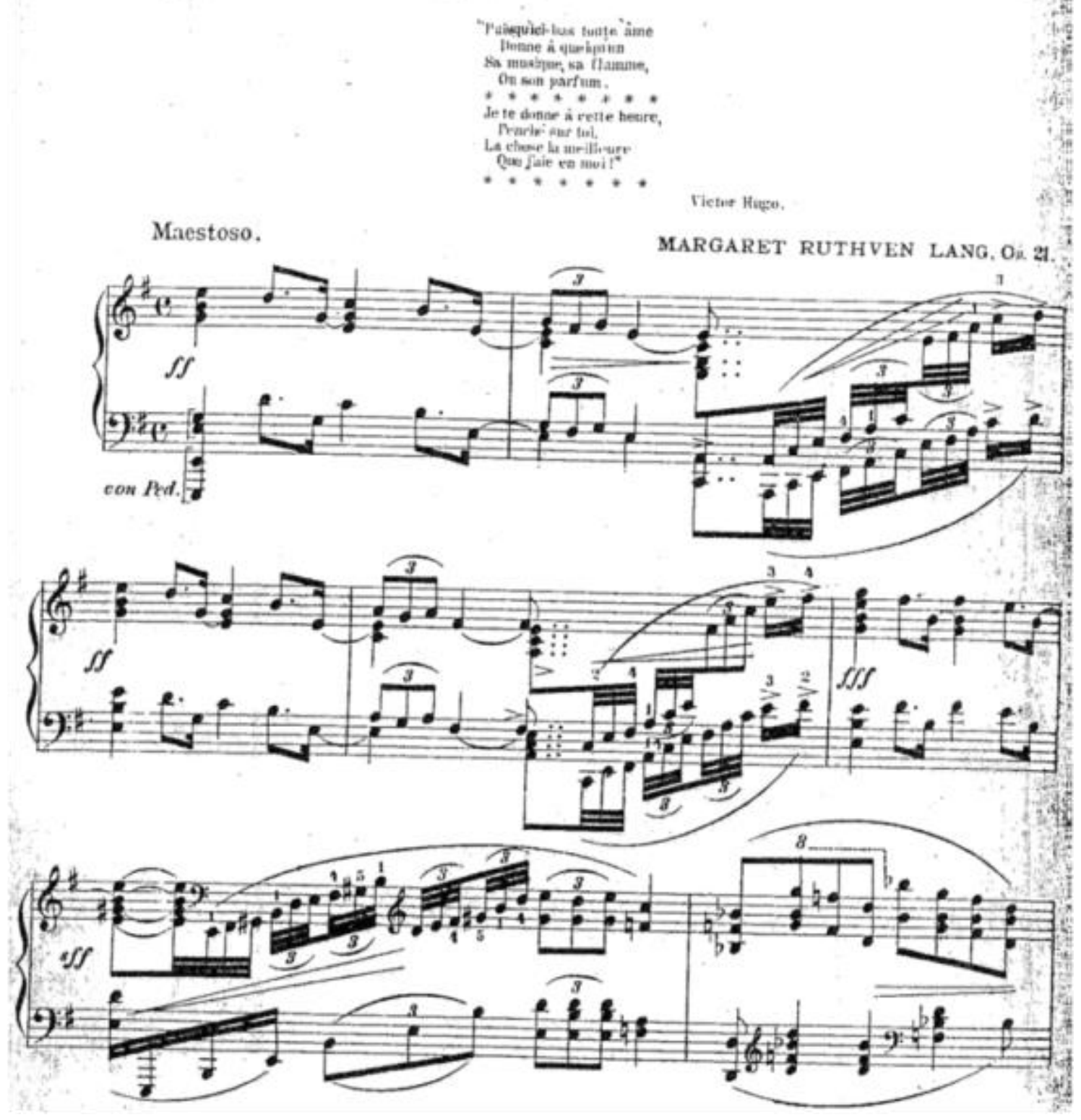

To the listener's ears, this piece gives a heroic, self-sacrificing impression. It is achieved

by the successful use of thick chords, running passages that sweep across the keyboard,

thick textures, loud dynamics, accents, and intense rhythm with the use of double-dotted and dotted notes. This theme appears for the second time at a forte dynamic, seemingly emphasizing the heroic phrase of "gives to someone." (example 6.2). 
Example 6.2 Margaret Ruthven Lang: Rhapsody, op. 21, mm. 8-10

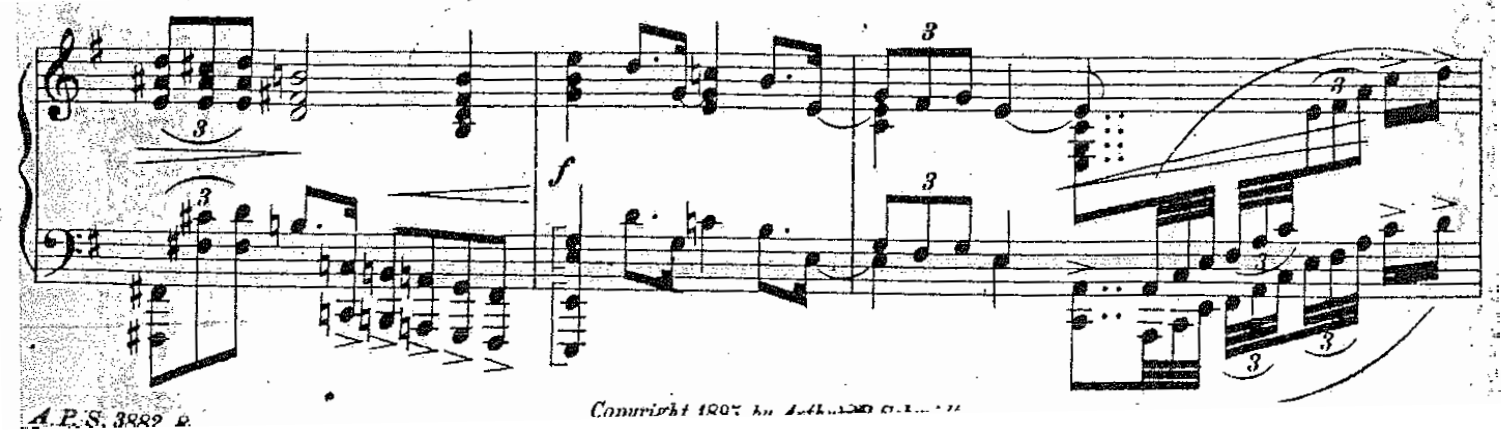

The theme in the A section appears five times. The third appearance, perhaps suggesting the phrase "his music," starts in the dominant and is ambiguous with regard to tonality; the passionate phrase "his fervor" seems well-described in Lang's music by the buildup from the previous phrase that reaches its fortissimo climax, supported by tremolos and accents, and finally settling into the key of the piece as the theme is announced again perhaps to recall the "perfume" (example 6.3).

Example 6.3 Margaret Ruthven Lang: Rhapsody, op. 21, mm.16-24






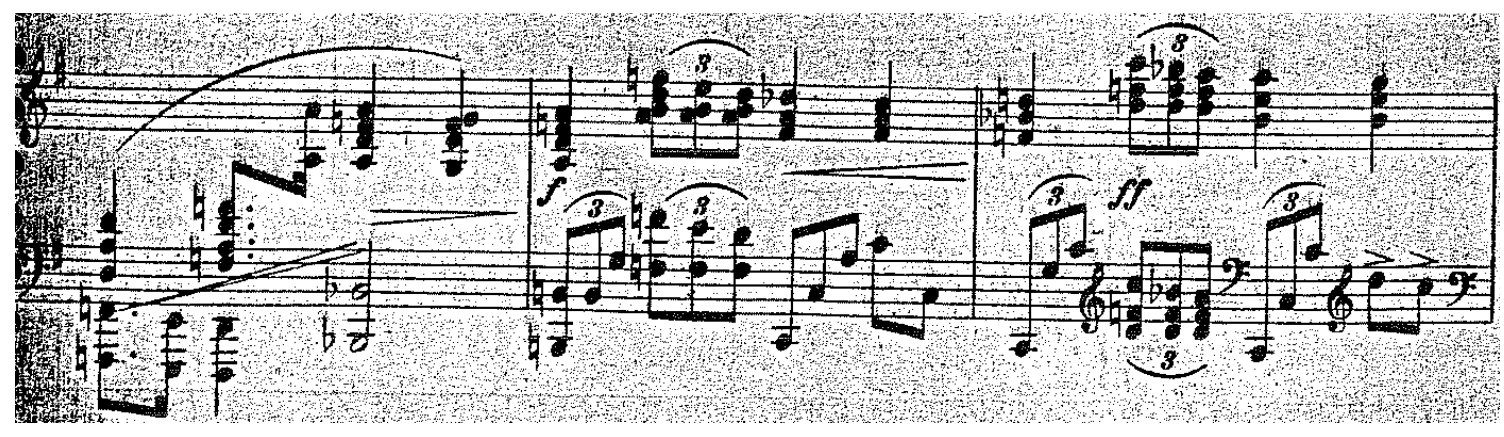

Example 6.4 Margaret Ruthven Lang: Rhapsody, op. 21, mm. 25-39
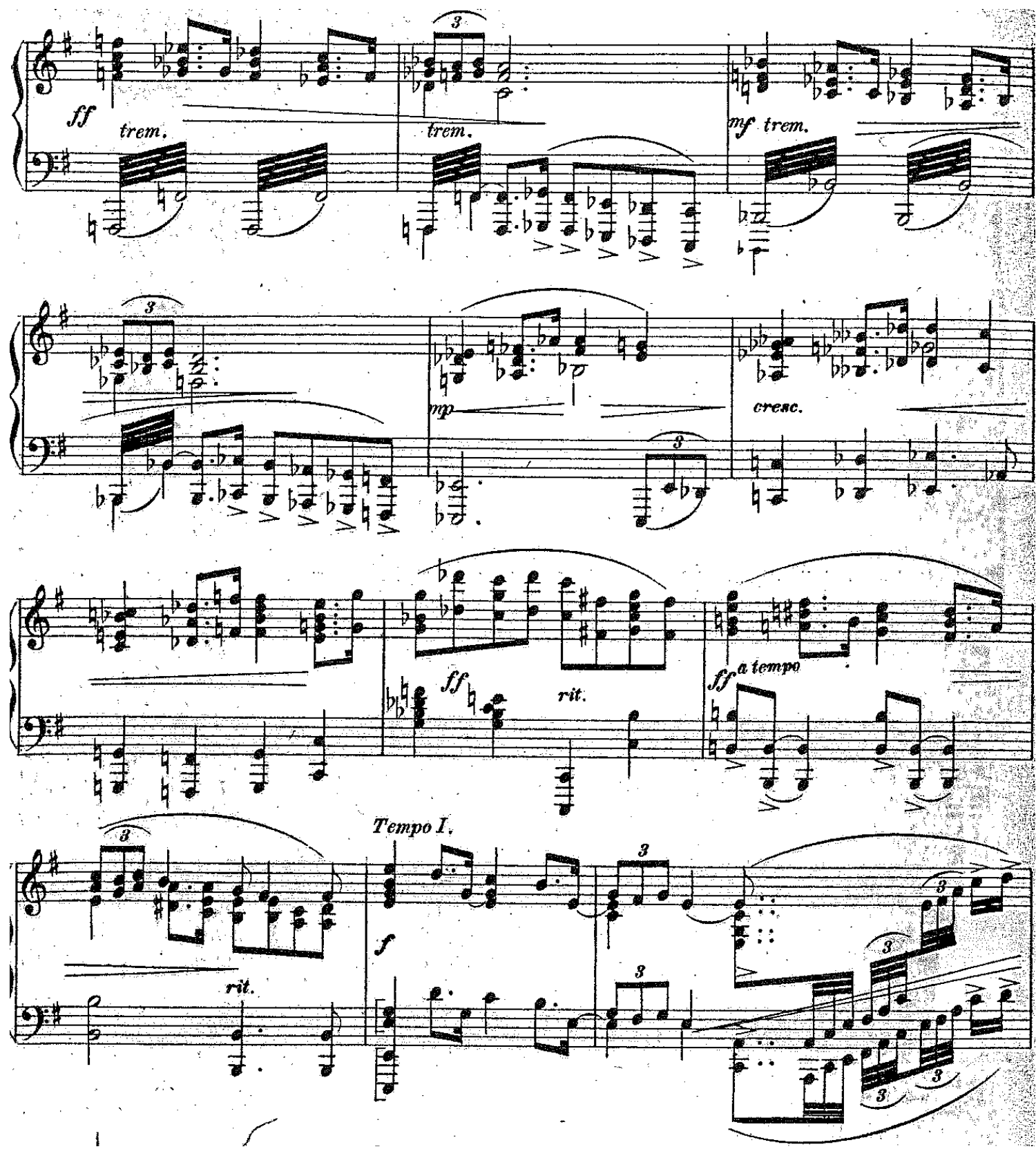


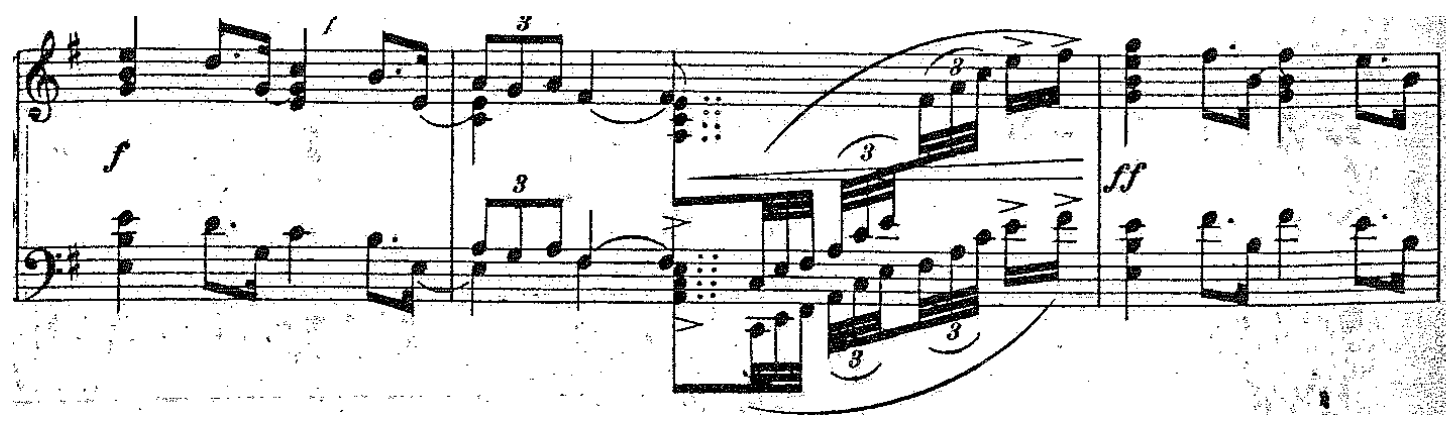

The coda prepares the entrance of the lyrical B section seamlessly with a transition from the e minor to A-flat Major. The theme of this B section is both a dignified and tender statement, as though addressed to the beloved; Lang marks this section con molto espressivo (example 6.5).

Example 6.5 Margaret Ruthven Lang: Rhapsody, op. 21, mm. 46-55

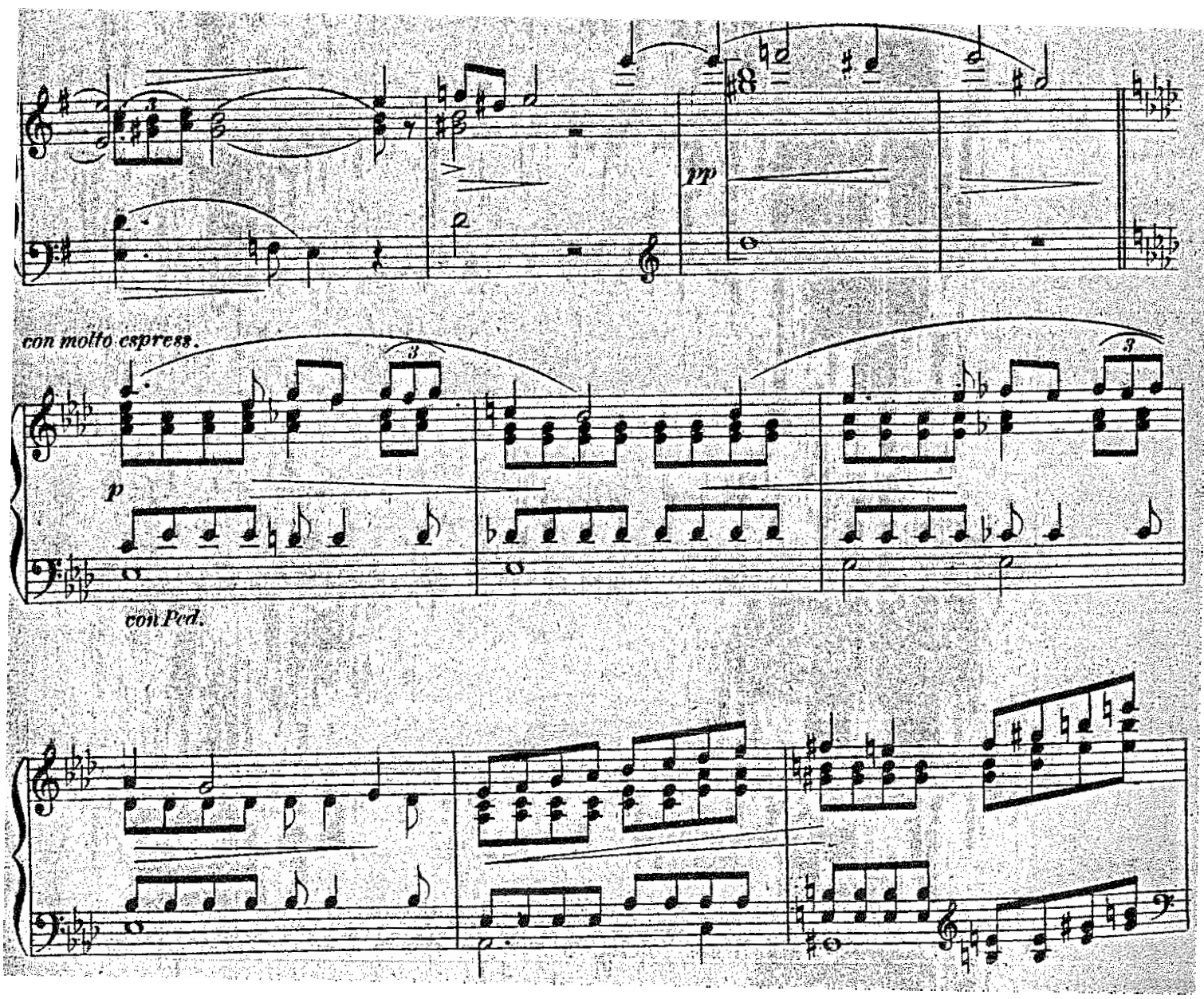


The second entrance of the B section is written with a thicker texture, softer, espressivo, and in the second inversion, venturing a new voicing and timbre (example 6.6).

Example 6.6 Margaret Ruthven Lang: Rhapsody, op. 21, mm. 62-67

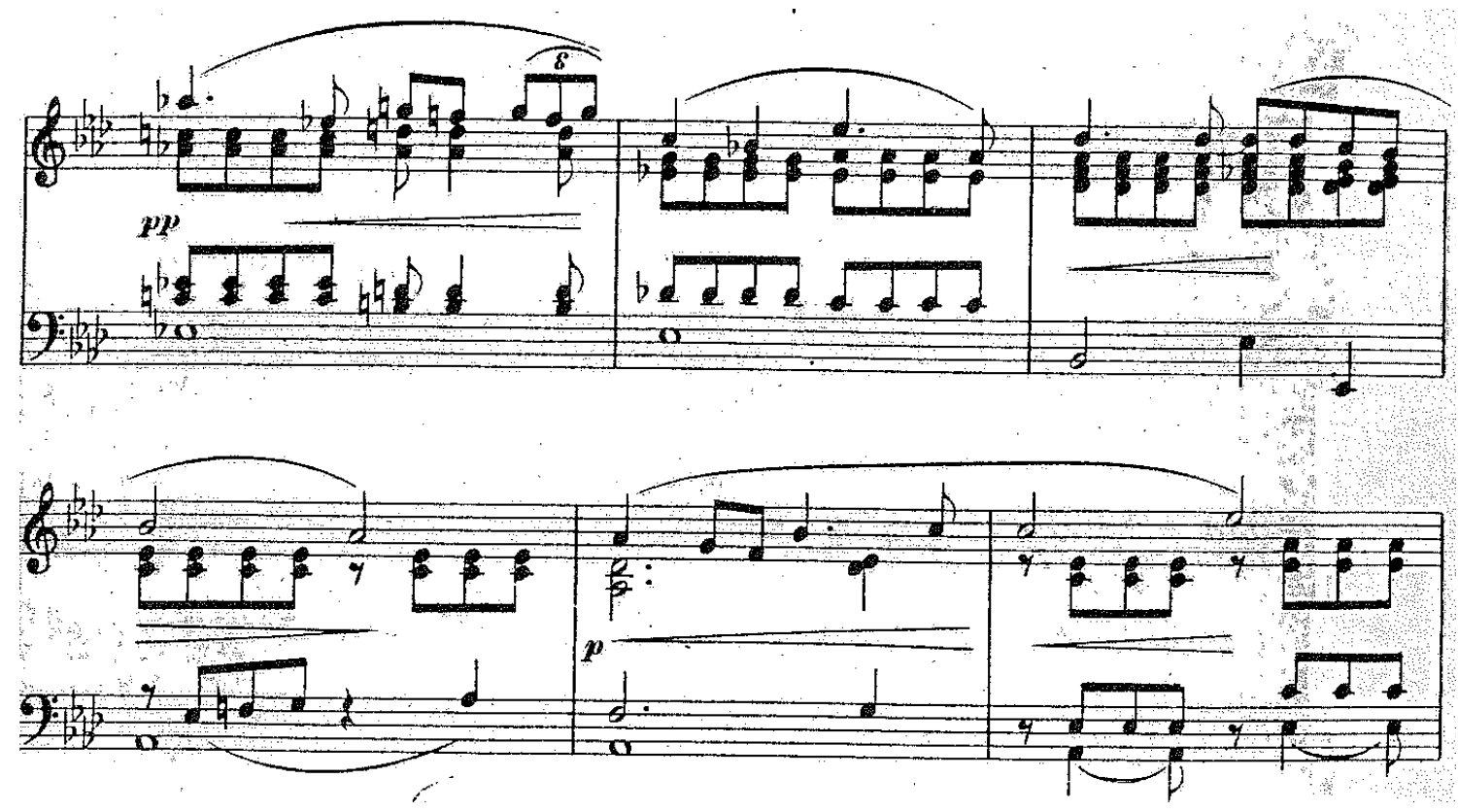

In mm. 70-75, Lang seems to suggest the phrase "leaning over you" by using a conversational phrase between the left and the right hands that gives urgency to the return of the B theme that symbolizes "you" (example 6.7).

Example 6.7 Margaret Ruthven Lang: Rhapsody, op. 21, mm. 68-77

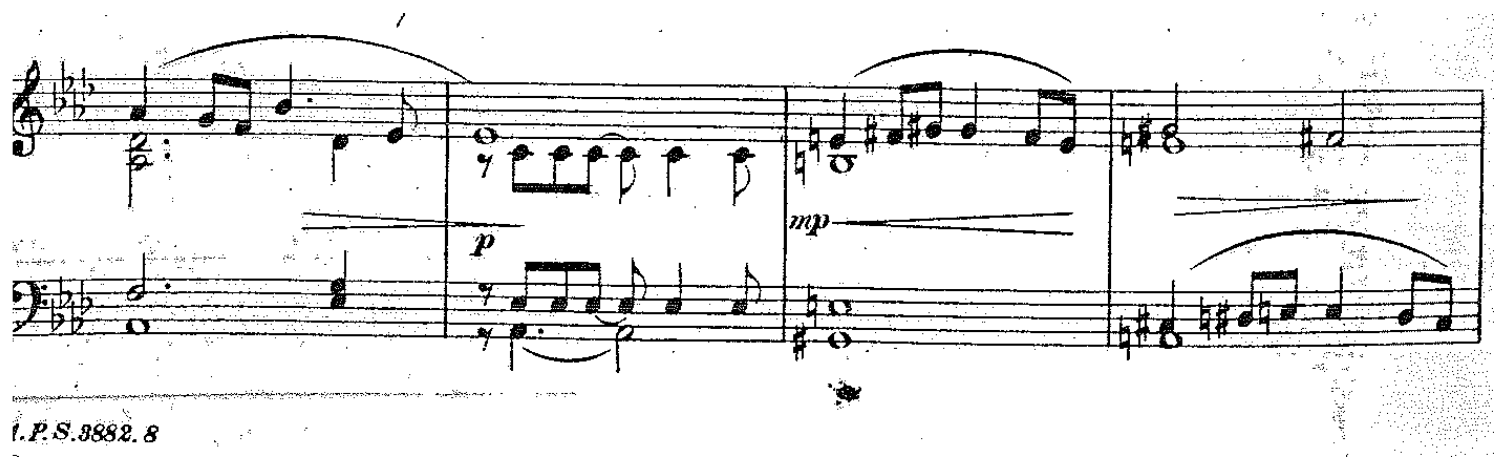

The last section of this Rhapsody is the coda. Lang marks this section largamente, with many arpeggio figures sweeping up and down the keyboard. Afresh, Lang explores the highest register and the lowest register of the keyboard to create a new, delicate 
timbre to call forth a flourished yet declaratory ending. It is written in E Major

(interestingly, the parallel major of the starting key, e minor). Does this use of the major

reflect a content ending as Hugo's poem suggests, "the best thing that I have in me!'?

(example 6.8).

Example 6.8 Margaret Ruthven Lang: Rhapsody, op. 21, mm. 102-112
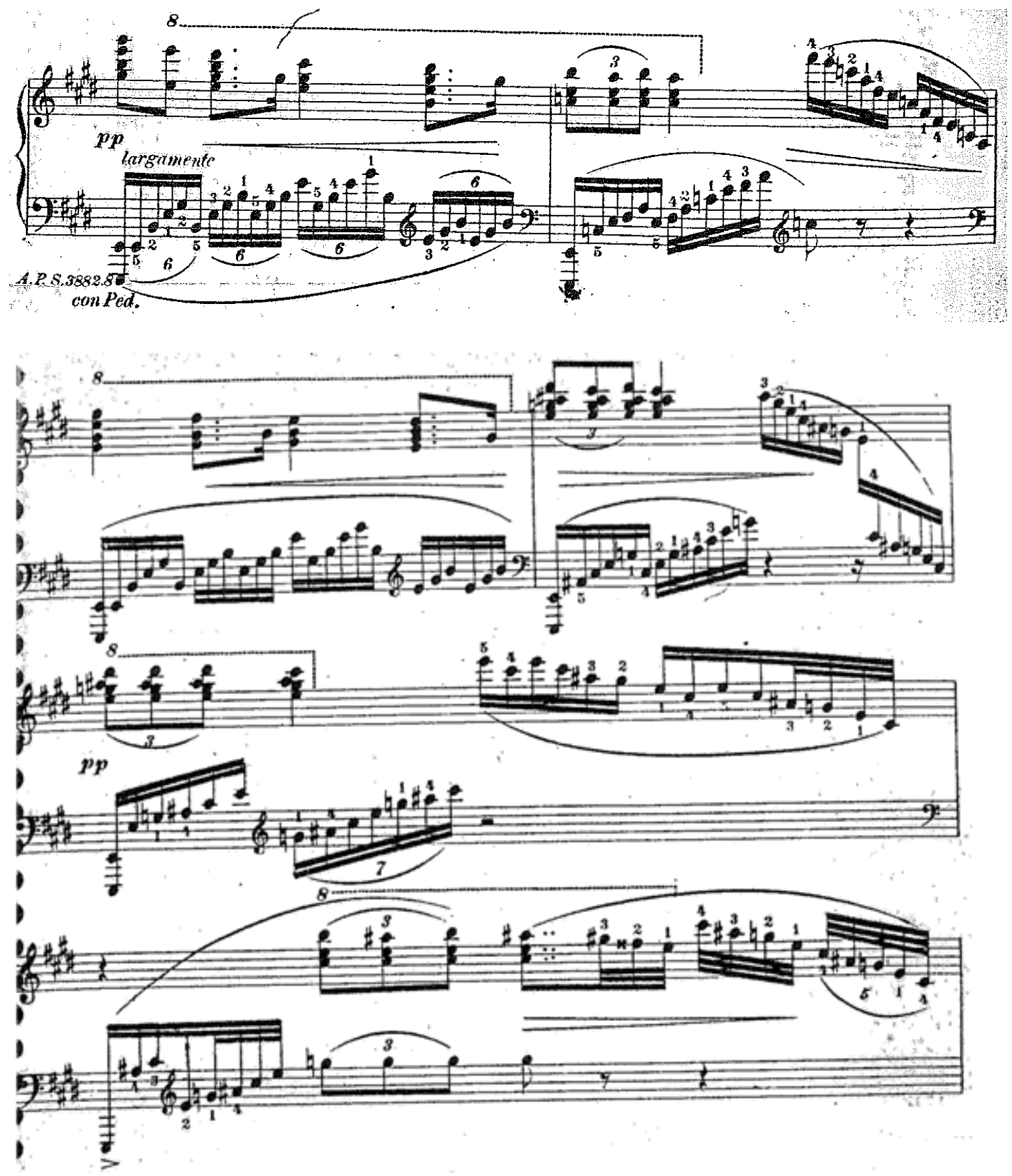


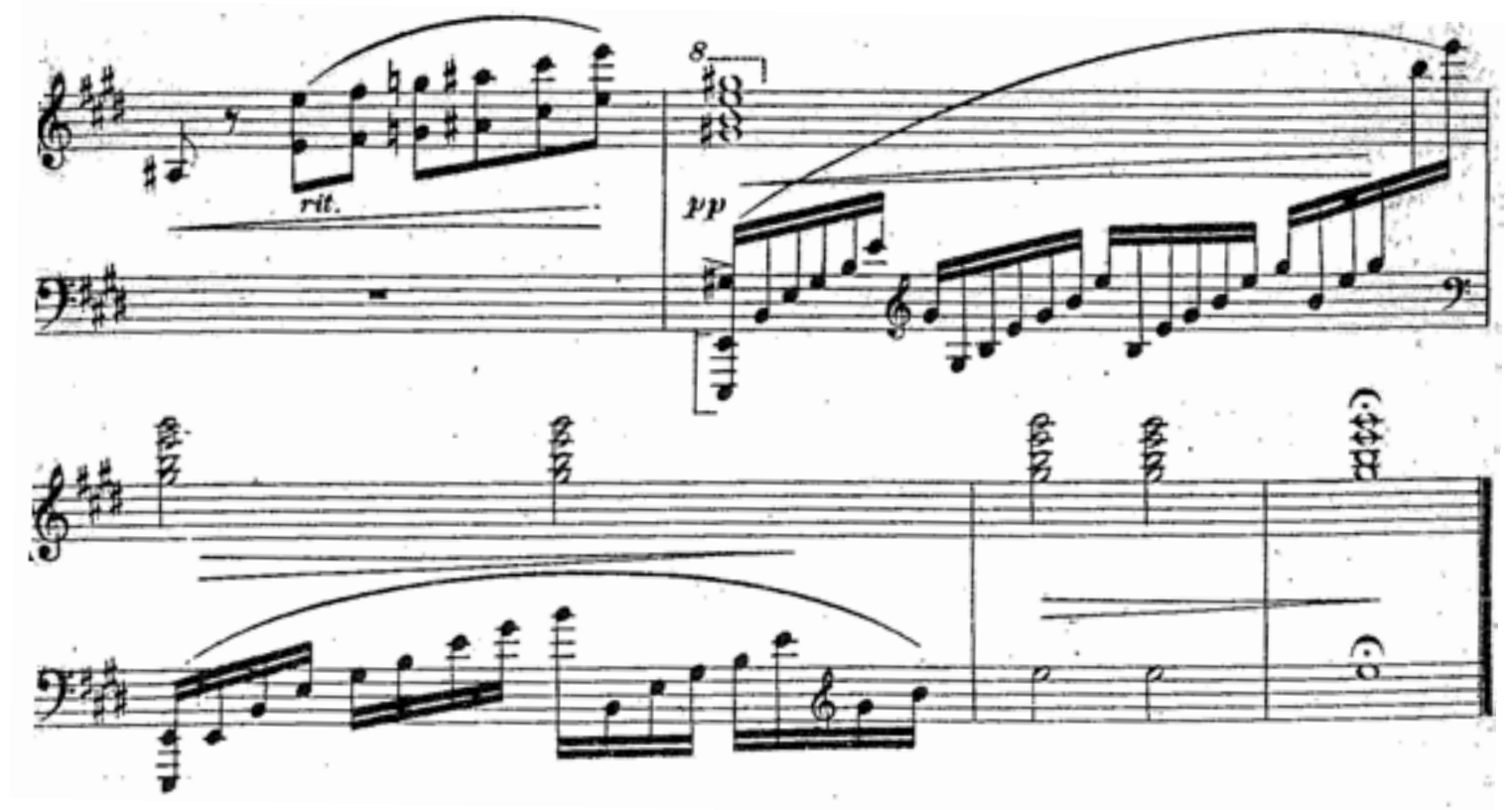

The technical challenges are significant for this piece: octave passages and chordal structures that span a broad range of the keyboard, fast passagework and voicing issues in the right hand. A particular challenge that performers will associate with Lang's Rhapsody is her interest in transposing entire sections of a work, changing inversions, extending the chords with additional notes, and changing half of the section to make it entirely new, and in doing so changing a lot of details such as chord voicing, arpeggio position, accompaniment patterns, or direction of the harmony. This piece would be suitable for high school, college level, or adult advanced students. Due to its content, the work requires emotional maturity. This piece also poses a physical challenge: the player needs big hands to accommodate wide stretches that cover an octave with sometimes moving inner voices. Since this piece may sound disjunct because of the contrast between sections, it is important for performers to be able to sustain the sense of unity that is reflected in the poem. 
Rhapsody seems to have enjoyed the popularity at the turn of the century. Below are records of the performances of Rhapsody:

- “On Wednesday, Jan. 28, 1903 Marion Arletta Mitchell, a student of B. J. Lang, performed Weber's Concert-stuck Opus 79 with B. J. playing the orchestral part on a second piano, and she opened her concert with Rhapsody in e minor by Margaret Ruthven Lang." 57

- "January 29, 1896 saw a performance of the piano Rhapsody [performer unknown] at the Rhode Island Women's Club." 58

- "Performances around the end of the century included Mrs. Stella HaddeAlexander playing the Rhapsody on Wednesday, January 4, 1899 at the Transportation Club (of NYC?)." ${ }^{, 59}$

- "Miss Alice Coleman performed the Rhapsody in e minor at Chickering Hall on February 19, 1901."60

${ }^{57}$ Johnston, "Margaret Ruthven Lang \& Family: List of Works, http://www.margaretruthvenlang.com (accessed February 15, 2013).

${ }^{58}$ Johnston, "Margaret Ruthven Lang \& Family: 1893-1925."

http://www.margaretruthvenlang.com (accessed February 15, 2013).

${ }^{59}$ Johnston, "Margaret Ruthven Lang \& Family: List of Works, http://www.margaretruthvenlang.com (accessed February 15, 2013).

${ }^{60}$ Johnston, "Margaret Ruthven Lang \& Family: List of Works, http://www.margaretruthvenlang.com (accessed February 15, 2013). 


\section{CHAPTER VII}

\section{FOUR PIANO WORKS: 1897-1899}

\section{Meditation, op. 26}

Meditation was published by Schmidt in 1897. It is written in E Major, and the tempo marking is Maestoso. The majestic character is shown in the opening by the stately chorale-like theme and the chordal accompaniment. Lang was a religious person throughout her life, and reflections of her spiritual life show in many of her works, in particular Meditation. William Smythe Babcock Mathews, the author of The Great in Music, quotes Lang's ideals as she stated them:

"It is my hope that in time to come the standard and general tone of church music shall be greatly raised; that the respect for a text used in music, which has so greatly increased in these last years as regards secular songs, shall find its way into the churches and a far greater reverence and consecration be attained, which shall draw sacred music towards the age of Palestrina, using secular intervals and modulations and the modern scale in only a moderate degree. In fact, establishing a general usage of music for the churches which shall be dedicated to their use alone. I have published as yet nothing which would illustrate my desire and hope as to this point. $" 61$

Meditation uses a traditional form and shows the characteristics of sacred writing with its hymn-like chords. The structure of this piece is ABA followed by a coda. The first theme appears in its grandeur leading to a passage which modulates to D-flat Major, an untraditional movement that heightens the grandeur the expression (example 7.1a).

\footnotetext{
${ }^{61}$ William Smythe Babcock Mathews, The Great in Music: A Systematic Course of Study in the Music of Classical and Modern Composers, 1 (Chicago: Music Magazine Publishing Company, 1900), 279.
} 
Example 7.1a Margaret Ruthven Lang: Meditation, op. 26, mm. 1-12

Op.26.
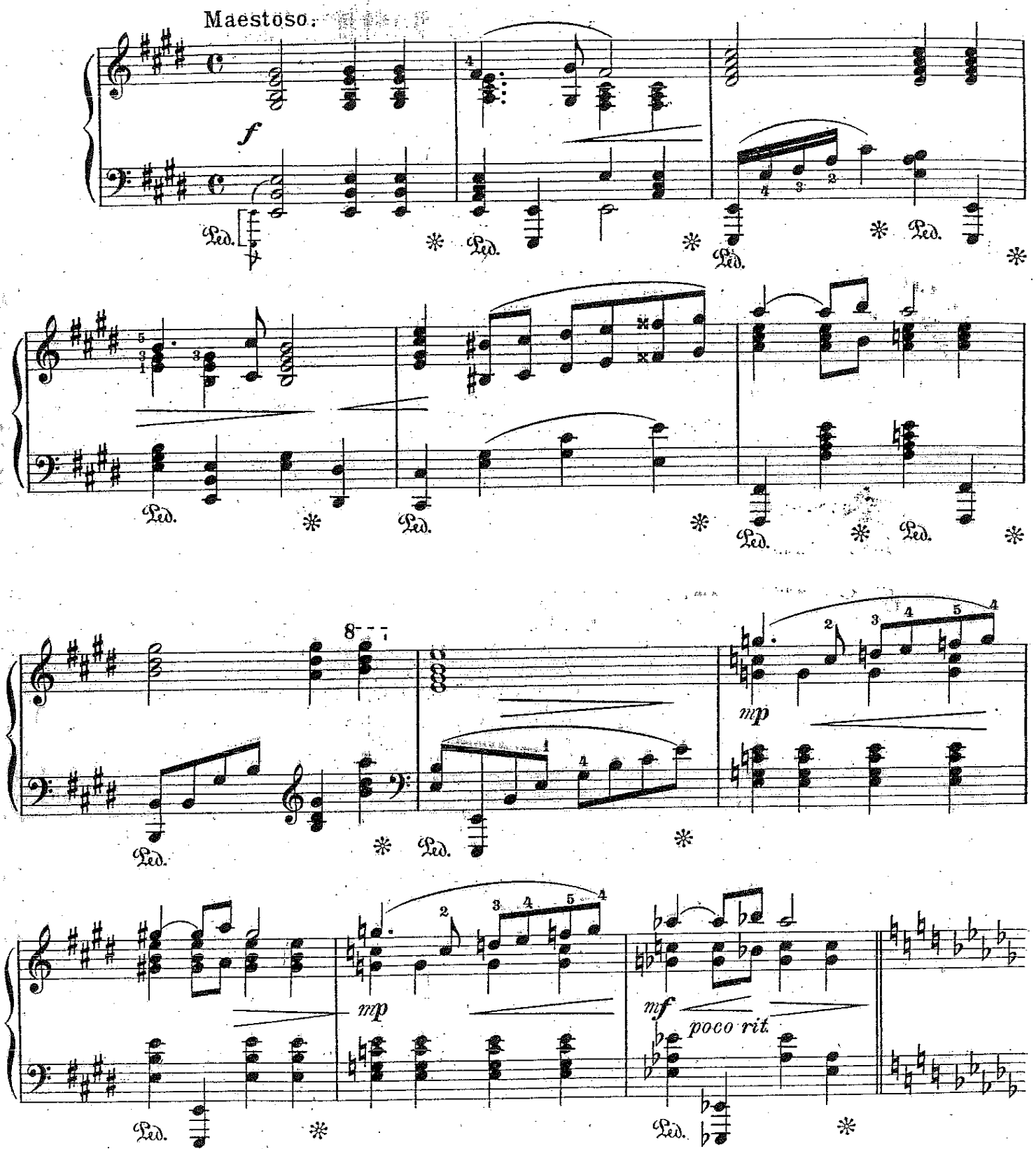

Sylvia Glickman, the editor of American Women Composers: Piano Music 1865-

1915 describes Meditation as "a solemn work, slowly building to a climax through a 
series of unusual modulations (E, D-flat, $C, E$ ) while varying the accompaniments to the steady rhythm of the chordal theme.",62

For the second theme, Lang makes a broad use of the keyboard with full, arpeggiated chords symbolic of majestic dignity. The chords in the higher registers resemble the reverberation of sounds in a church setting; the left hand arpeggiated accompaniments in a sense emulate chimes (example 7.1b).

Example 7.1b Margaret Ruthven Lang: Meditation, op. 26, mm. 13-15

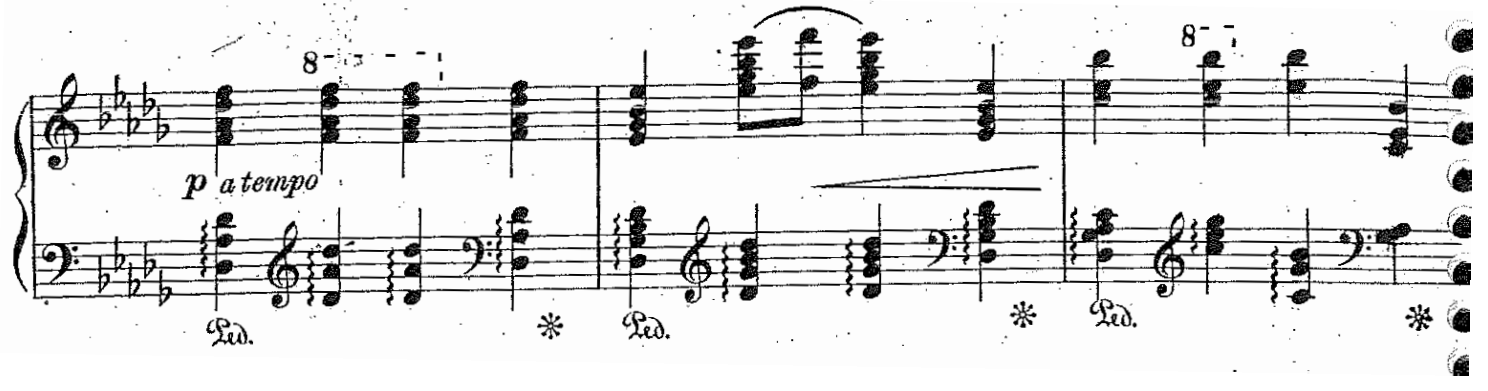

These dramatic chords lead to an exalted passage in the key of C Major, well-planned to heighten the tension for the return to the A section in the home key, a mediant relationship, back to E Major (example 7.1c).

Example 7.1c Margaret Ruthven Lang: Meditation, op. 26, mm. 13-28

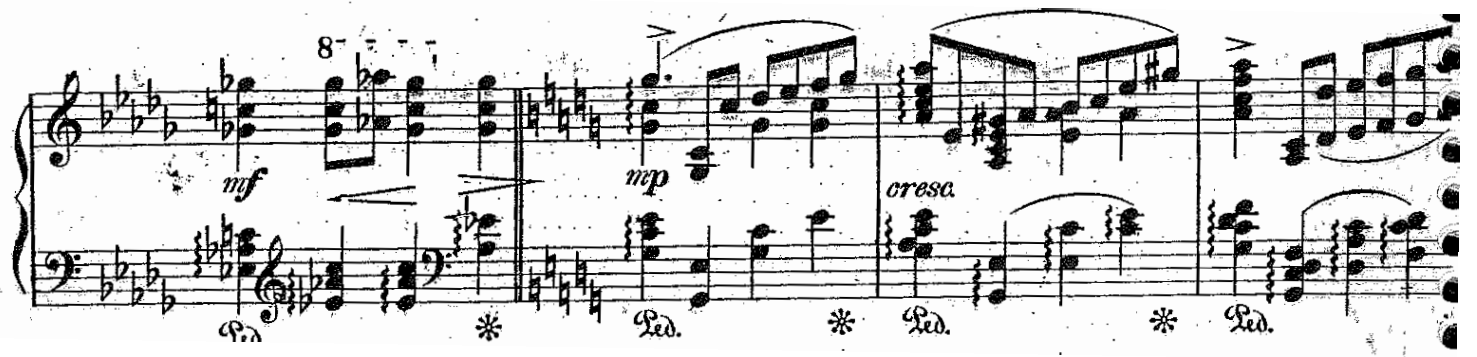

\footnotetext{
${ }^{62}$ Johnston, "Margaret Ruthven Lang \& Family: 1893-1925,"

http://www.margaretruthvenlang.com/ (accessed March 9, 2013).
} 

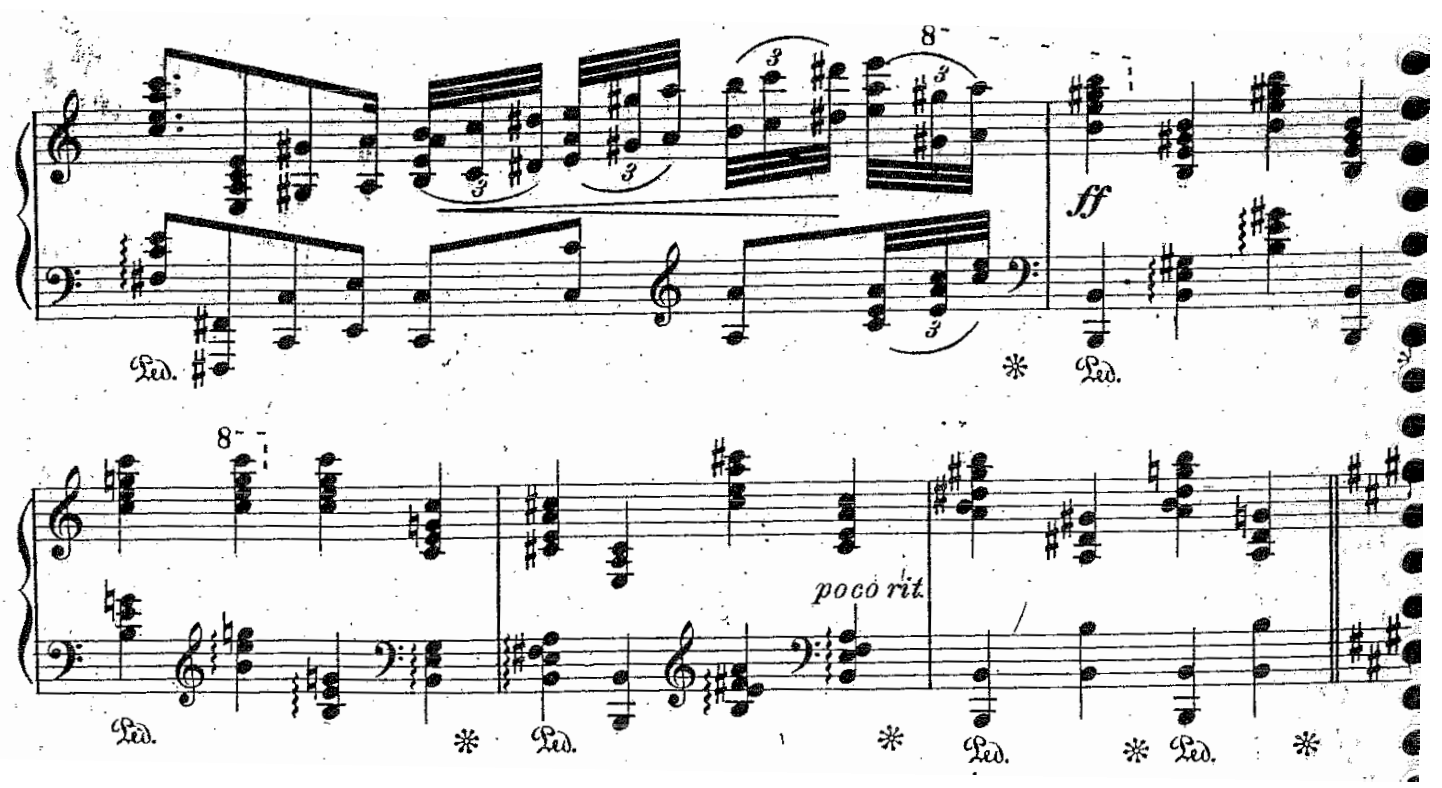

The opening theme returns, but this time Lang combines it with a rhapsodic

sweeping accompaniment figure in the left hand (example 7.1d).

Example 7.1d Margaret Ruthven Lang: Meditation, op. 26, mm. 29-33

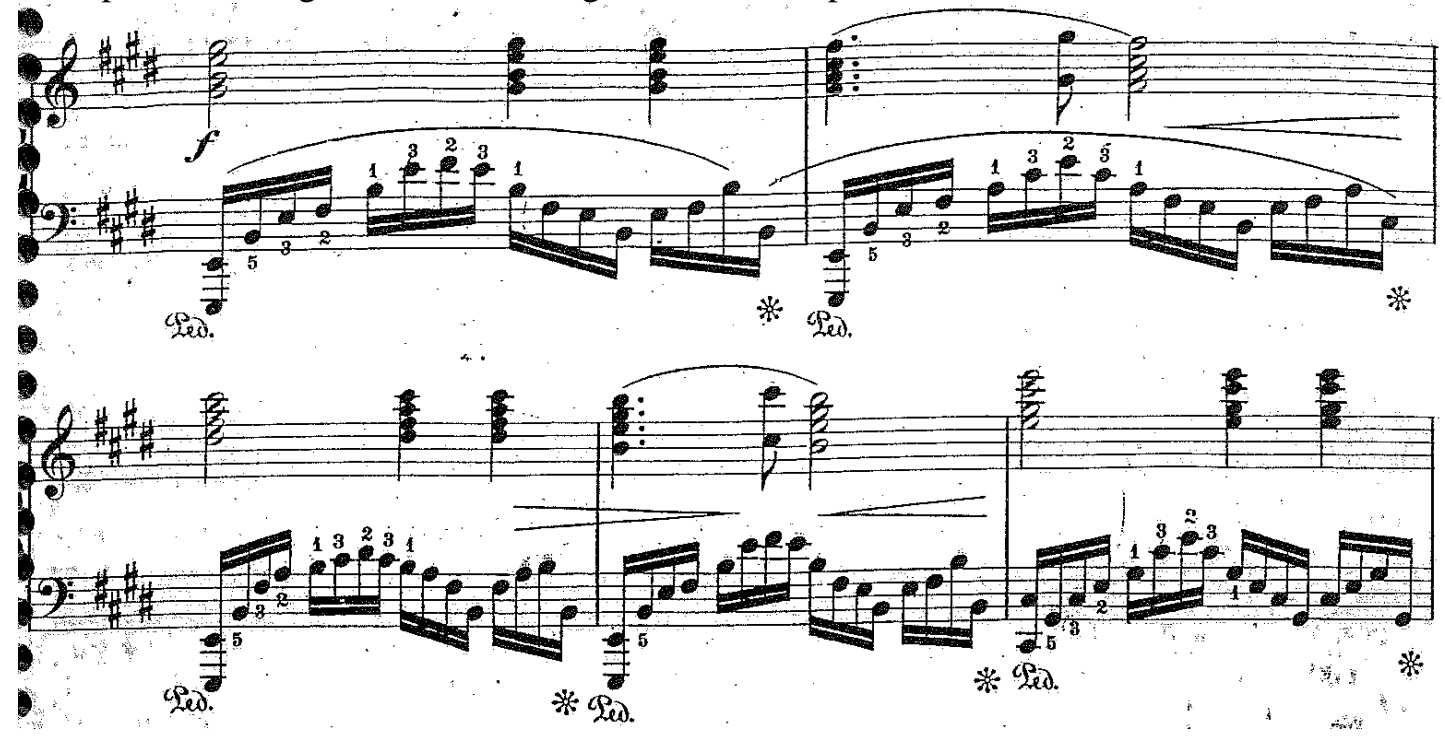

The hymn-like chords return in the coda which transitions into grand arpeggios.

Lang ends her Meditation in divine grandeur (example 7.1e). 
Example 7.1e Margaret Ruthven Lang: Meditation, op. 26, mm. 43-58
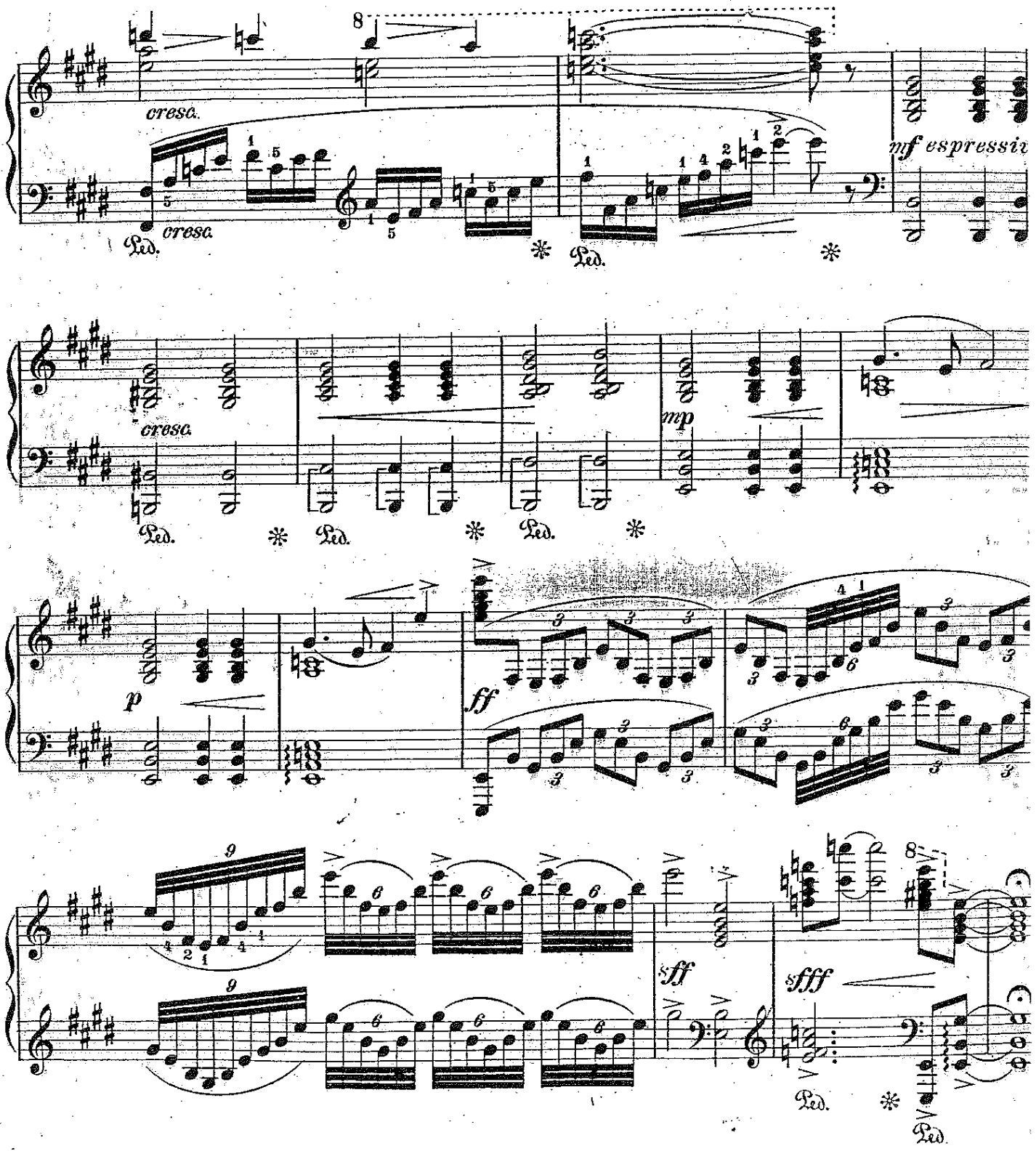

This piece is suitable for early advanced students. The work is composed in a thick texture that requires large spans for both hands and agility of the left hand in the arpeggiated accompaniments. 


\section{Springtime, op. 30}

Springtime was published in 1899 in volume IV of The World's Best Composers edited by Victor Herbert. ${ }^{63}$ Lang's work flourished in 1899 as she published three piano works that year and Springtime was her first composition. In this gay-sounding work, Lang marks the tempo "cheerily, in spirited movement." Lang achieves the joy of spring through the major tonality, the lilting $9 / 8$ meter, and her particular use of grace notes throughout representing the sweet chirping of birds.

The formal scheme of this work is cast in ABABA. The joyful opening tune is answered with brief ascending motives in the left hand, with the exchanging of this cheerful tune found throughout the piece. This opening theme also includes the gracenote motive. Lang cleverly transcribes the sounds of birds by using these grace notes which appear throughout the entire piece. As the snow melts, the birds are celebrating Springtime (example 7.2a).

Example 7.2a Margaret Ruthven Lang: Springtime, op. 30, mm. 1- 20

\section{SPRINGTIME。}

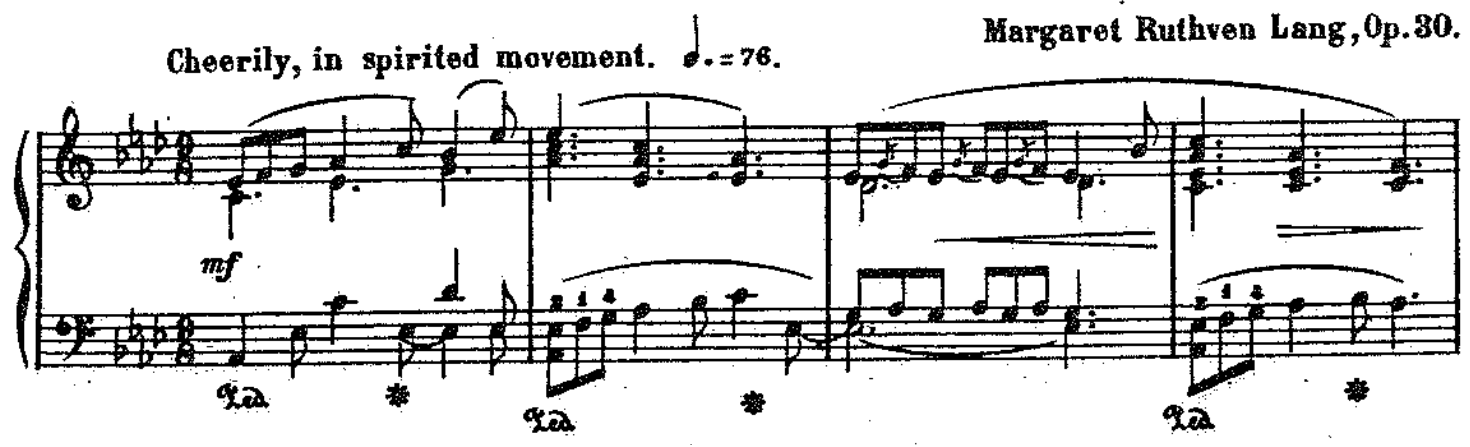

\footnotetext{
${ }^{63}$ Victor Herbert, The World's Best Composers, IV (New York: New York University Society,
} 1899), 967-970. 

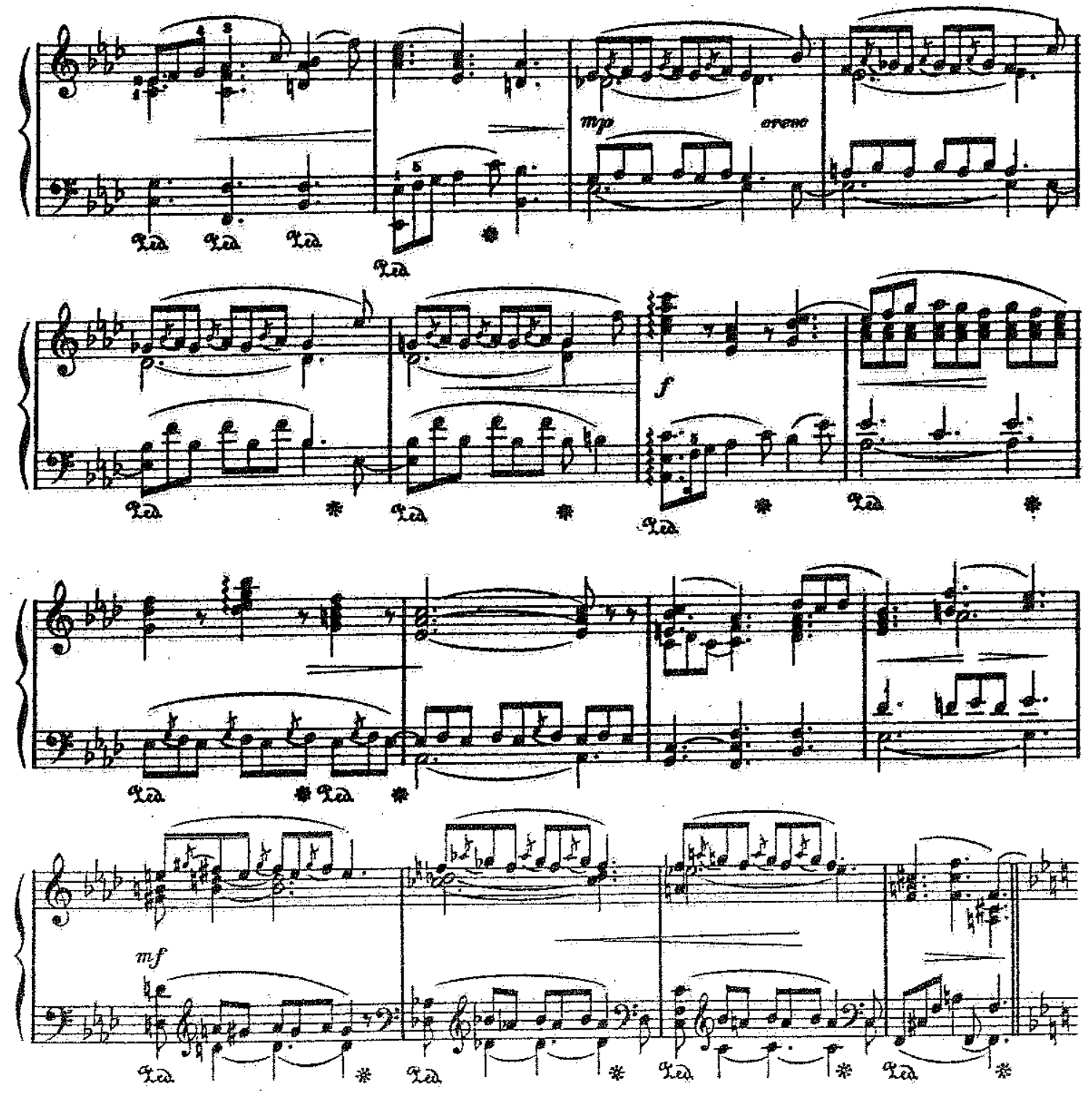

Copgright 4000 bo G.d. mrgan.

The B section is written in a slower rhythmic movement. Lang makes use of horn call-

like motives here and also introduces a spirited dotted rhythm leading to the return of the

A section (example 7.2b). 
Example 7.2b Margaret Ruthven Lang: Springtime, op. 30, mm. 21-37
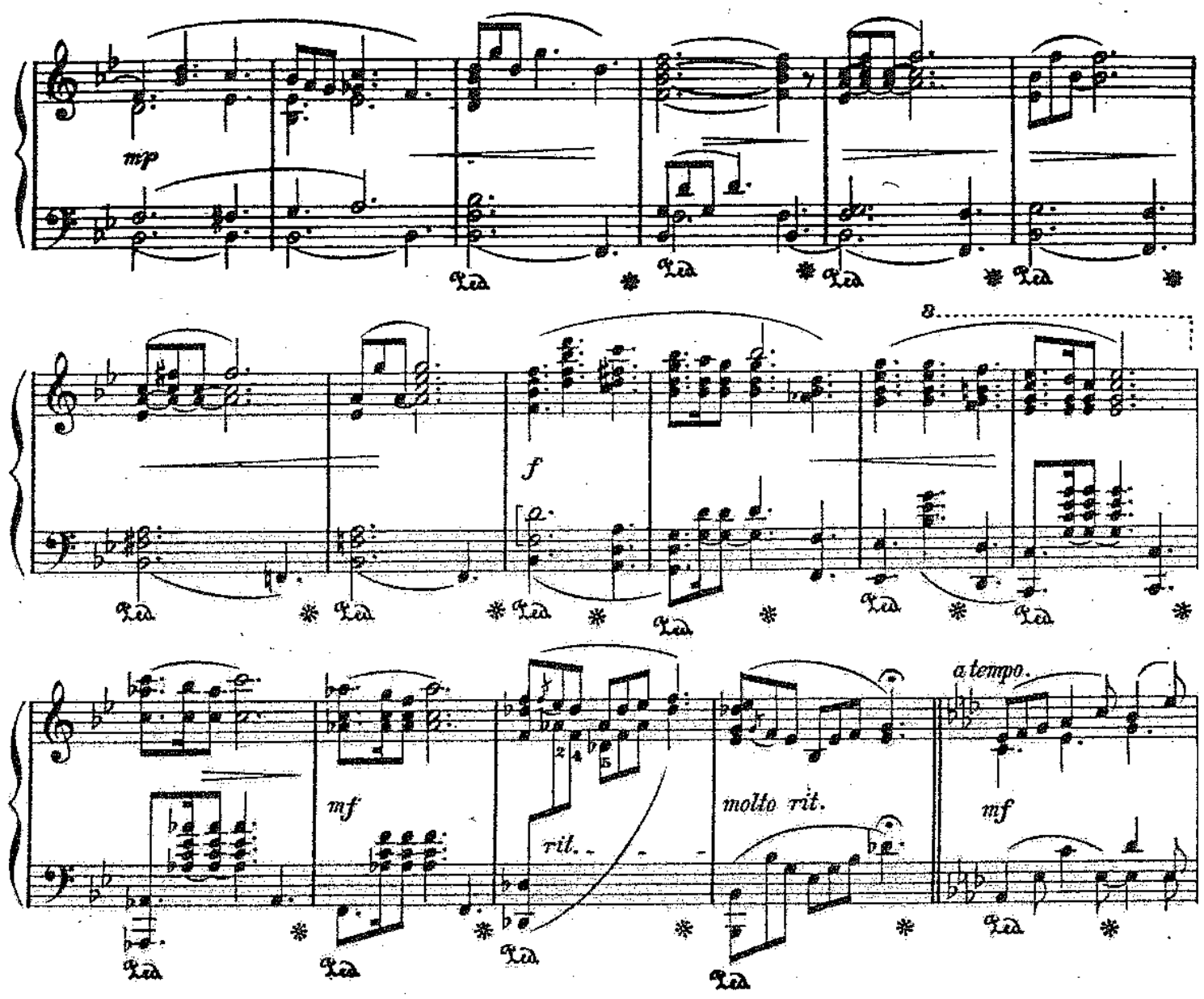

Lang reserves the climactic moment until the end of the piece to portray the triumph of spring (example 7.2c) 
Example 7.2c Margaret Ruthven Lang: Springtime, op. 30, mm. 79-89
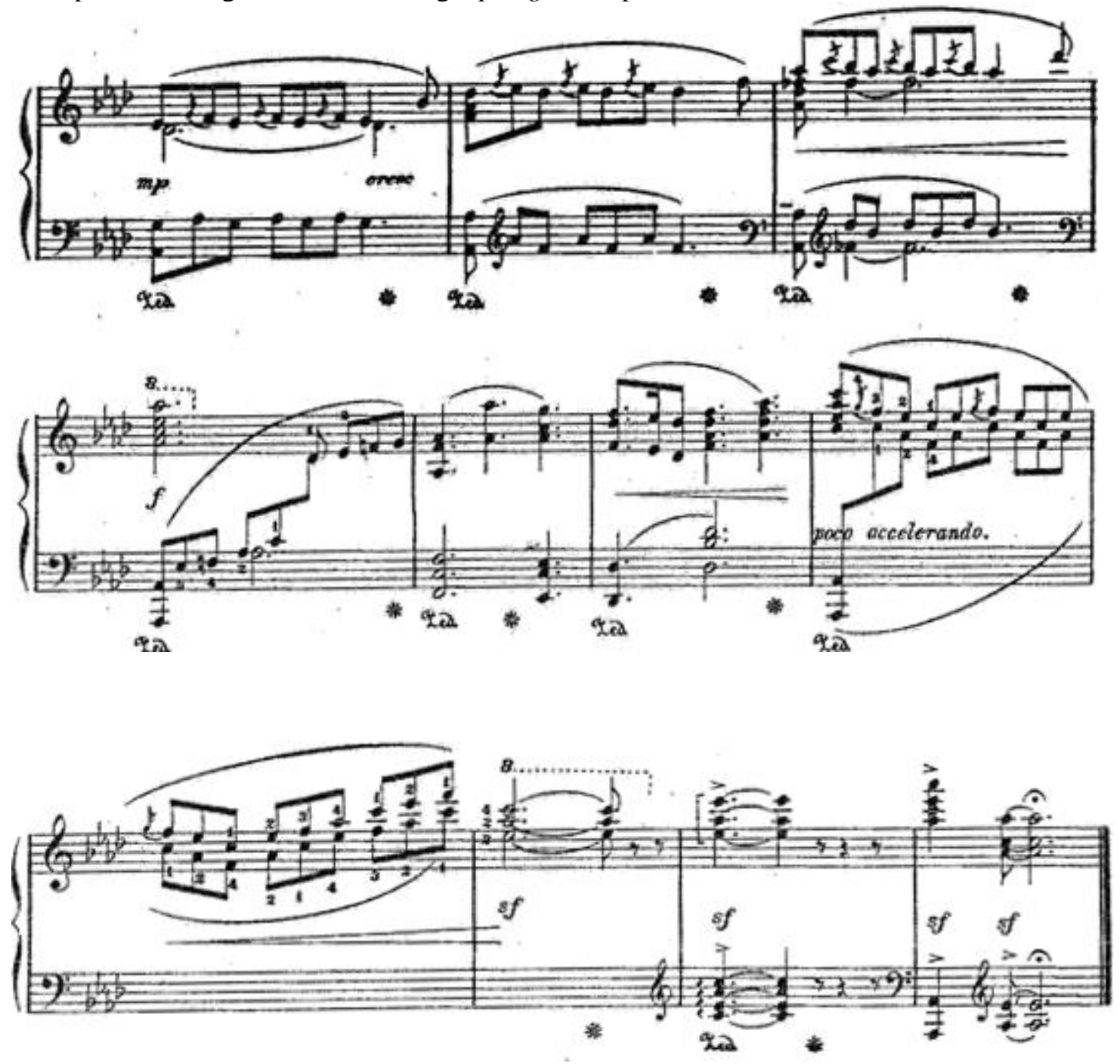

This is a charming piece but not without its technical challenges. It is well suited for the early advanced student. The crisp grace notes found throughout pose special challenges to perform them cleanly and quickly, and the exchange of motives between the hands, large chords and brisk tempo make this work a most effective study piece. 


\section{Revery, op. 31}

Revery was published in 1899 by the John Church Company in The World's Best Composers. The John Church Company was an American publishing company that specialized in sheet music in the nineteenth century. This company published music by John Philip Sousa, Dan Emmett, Lang, and others. Later, it was bought by the Theodore Presser Company in $1930 .^{64}$

Again, Lang uses poetry here as her inspiration which she inserts at the top of the score. "Sleep," written in 1892 by John Banister Tabb (1845-1909) evokes a dreamy, reflective atmosphere:

"What art thou, balmy sleep?

Foam from the fragrant deep

Of silence, hither blown

From the hushed waves of tone!"

Tabb was an American poet, a Catholic priest and an English teacher at St.

Charles College in Maryland. According to Jessie Belle, the author of The Little Book of American Poets: 1787-1900, "His [Tabbs'] work is almost wholly in very brief lyrics wrought with infinite pains" and she continues on saying that, "He [Tabb] is the lapidary of verse and his gemlike work is cold and shining. Nevertheless, it is artistically distinguished and unique." $" 65$ Tabb's poems were widely published, found in many of the foremost magazines. "In the lyric field he was greatly admired. Under his muse inanimate things took on life and beauty and the abstract became concrete and personal. His poems

\footnotetext{
${ }^{64}$ Theodore Presser Company, "The Presser Story,” About Us, http://www.presser.com/aboutus.cfm (accessed February 21, 2013).

${ }^{65}$ Quoted in "John B. Tabb," http://www.poetry-archive.com/t/tabb_john_banister.html (accessed February 23, 2013) from Jessie B. Rittenhouse, The Little Book of American Poets: 17871900(Cambridge: Riverside Press, 1915).
} 
are collected in five volumes, which were published in the following order: "Poems", "Lyrics", "Child Verse", "Later Lyrics", and "Sonnets". ${ }^{66}$

Revery was published in 1899, ten years after the World Exhibition took place in Paris where Lang's “Ojalá” was chosen to be performed. There, Claude Debussy (1862 1918) who was five years older than Lang was inspired. To Debussy, it was such an eyeopening event that "he became enthusiastic about Oriental art of all kinds, and he was particularly enthralled by the sounds of the Javanese gamelan orchestras. ${ }^{~} 67$ Was Lang, some ten years later, facing the same experience as Debussy that she found new and exotic sounds as a fresh source of inspiration?

Lang was also a close friend of Charles Martin Loeffler (1861-1935), the socalled "American Impressionist," who was a French-born American violinist and composer that immigrated to the United States in 1881. According to Cline, they spent time analyzing his scores. Through her published works though, there is no evidence that Lang expanded her tonal language based on her time working with Loeffler. ${ }^{68}$

The title Revery evokes a pensive, almost subliminal atmosphere. Literally translated "daydream," there is a suggestion of sleep. According to Hughes, "the exquisiteness of sleep is the theme. The music is delicious, and the ending is a rare proof of the beautiful possibilities of dissonance." ${ }^{, 69}$ Twenty years later in one of her last collections, Three Pieces for Young Players, Lang named another composition "Day-

\footnotetext{
${ }^{66}$ Thomas Duggan, "John Bannister Tabb," The Catholic Encyclopedia, vol. 14 (New York: Robert Appleton Company, 1912). http://www.newadvent.org/cathen/14423c.htm (accessed February 23, 2013).

${ }^{67}$ Gordon, A History of Keyboard Literature: Music for the Piano and Its Forerunners, 358.

${ }^{68}$ Cline, "Margaret Ruthven Lang: Her Life and Songs," 38-9.

${ }^{69}$ Cline, "Margaret Ruthven Lang: Her Life and Songs,"11.
} 
Dream." This concurrence is frequently encountered in her works as it shows Lang's endless creativity through the same source of inspiration.

Lang's creativity in delineating the dream-like atmosphere here is through her experimentation with various compositional styles, trying to incorporate elements of exoticism and other imaginative sounds. She uses the repetitively hypnotic effects and rhythms of the gamelan, effectively weaving the texture of Revery. The alternating accompanying figure with the help of the pedal, creates a blurry or dreamy effect, suggesting the transition between reality and the world of dreams. It challenges the performer to achieve intelligible clarity between melody and accompaniment (example 7.3a).

Example 7.3a Margaret Ruthven Lang: Revery, op. 31, mm. 1-16

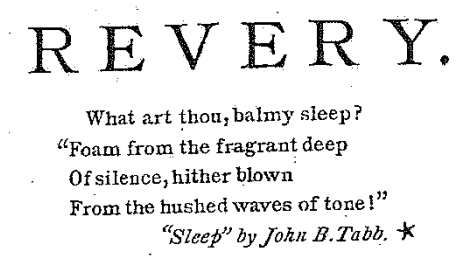

Margaket Ruthyen Lang, Opus $\mathbf{3}$.

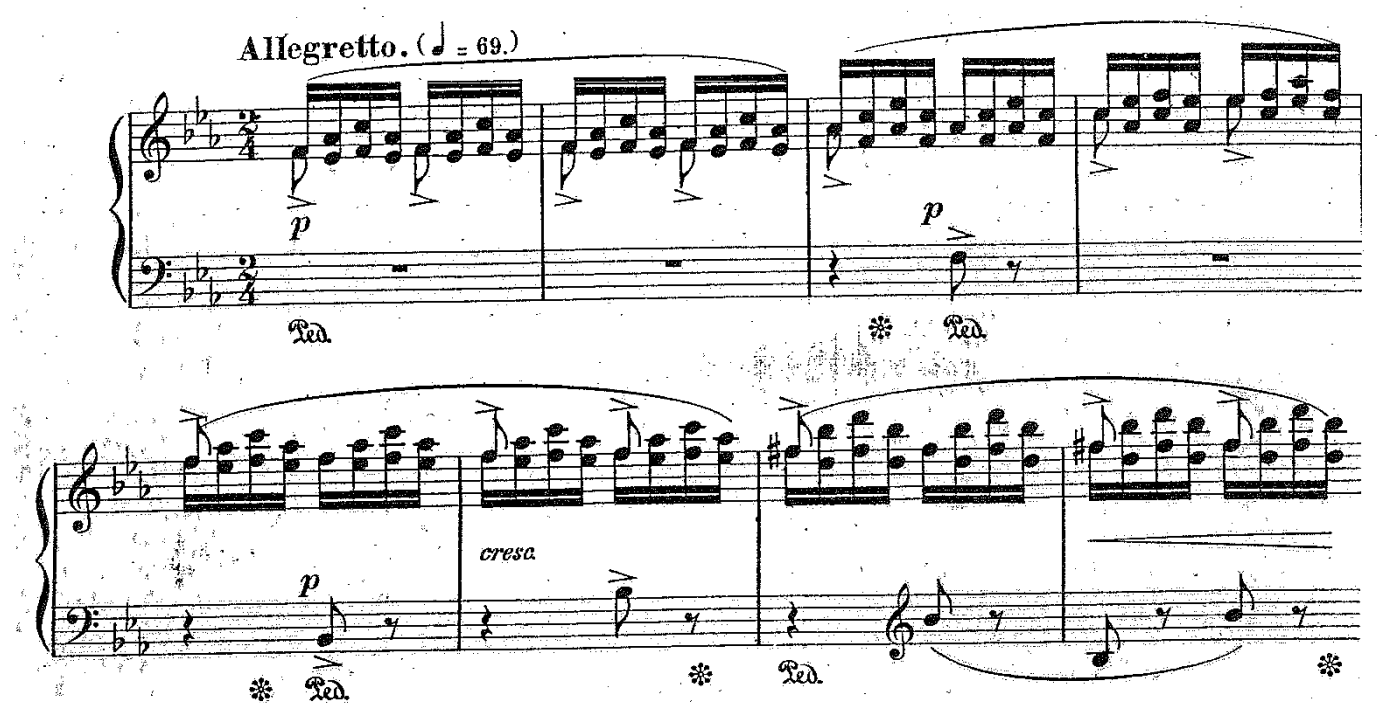




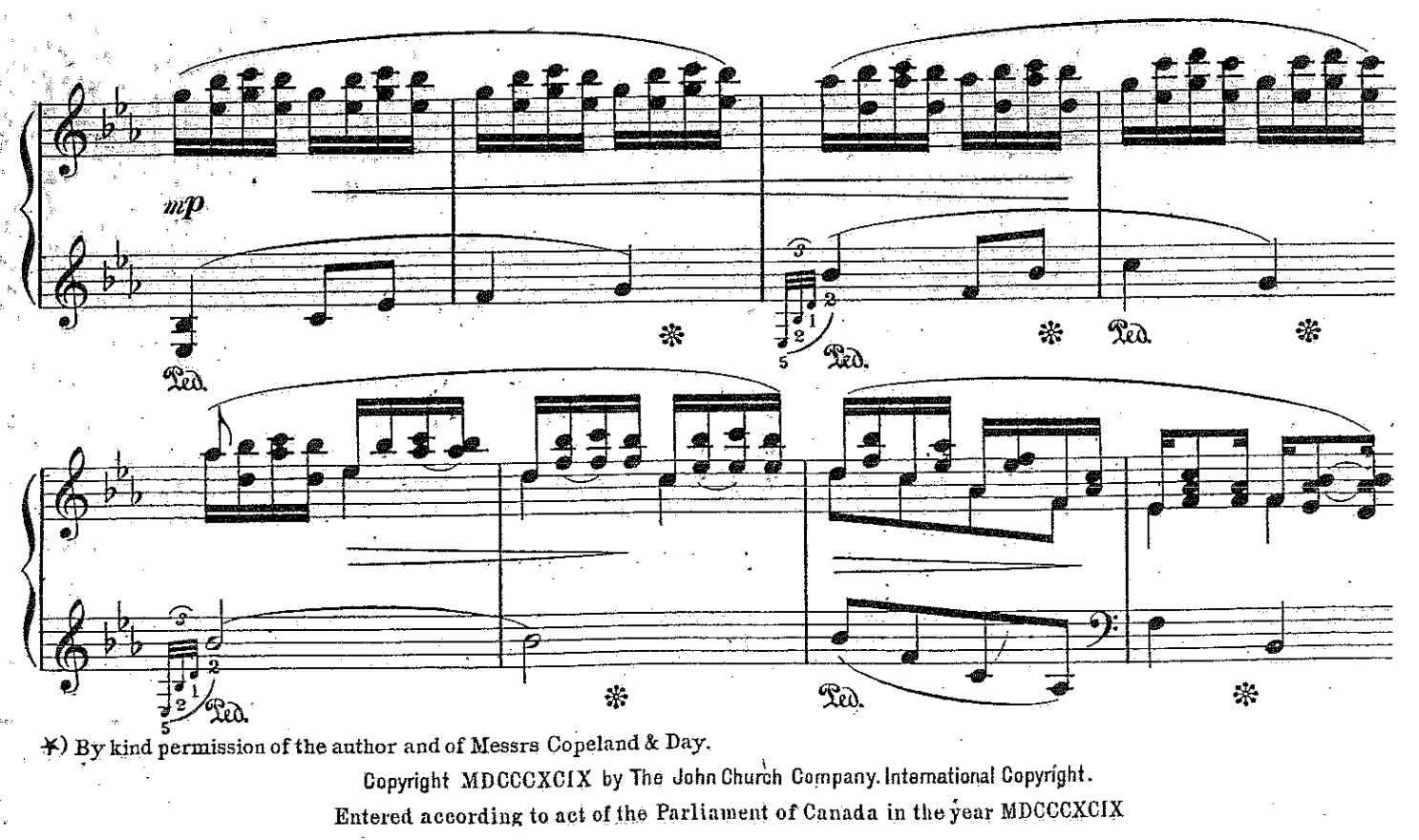

Karleton Hackett once wrote about Revery:

"[Revery is] more like a study than an improvisation. In the right hand a persistent figure in double notes, while the melody comes in the left, slightly after the manner of Rubinstein's 'Kamennoi Ostrow,' Opus 10, no. 22. The main idea is relieved by a pleasing passage of wide chords, in the manner of a harp. Capable of producing a good effect when well played." ${ }^{, 70}$

As Hackett suggests, Anton Rubinstein's Kamennoi Ostrow (Cloister Scene)

bears some resemblance to Lang's Revery. Both works start with a dreamy alternating right hand accompaniment figure with the melody in the left hand (example 7.3b).

${ }^{70}$ Mathews, The Great in Music, 281. 
Example 7.3b Anton Rubinstein: Kamennoi Ostrow from Album of 24 Portraits, op. 10, no. 22, mm. 1-19.
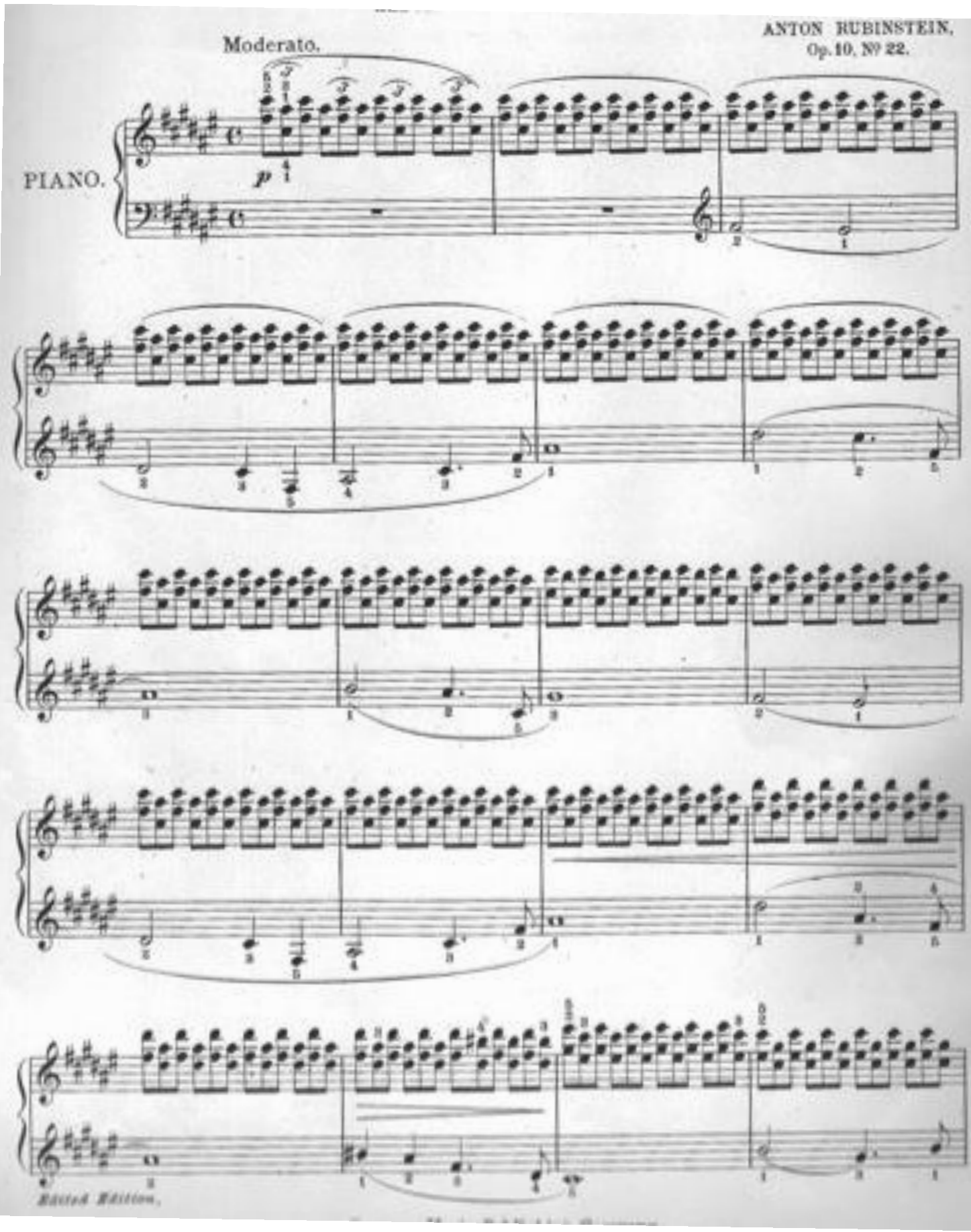

Unlike Rubinstein, Lang begins Revery with tonal ambiguity: a root position

supertonic seventh chord, inversions of which evolve and lead to an augmented dominant 
which finally resolves to the tonic E-flat in the ninth measure. Lang creates a beautiful, dream-like effect with these colorful harmonies, dynamics and registers.

For a second theme, Lang uses an arpeggiated, harp-like series of major and minor chords in inversions; it produces a sonority and coloristic effect that simulate drops of wonder, creating ripples of questions (example7.3c).

Example 7.3c Margaret Ruthven Lang: Revery, op. 31, mm. 27-34
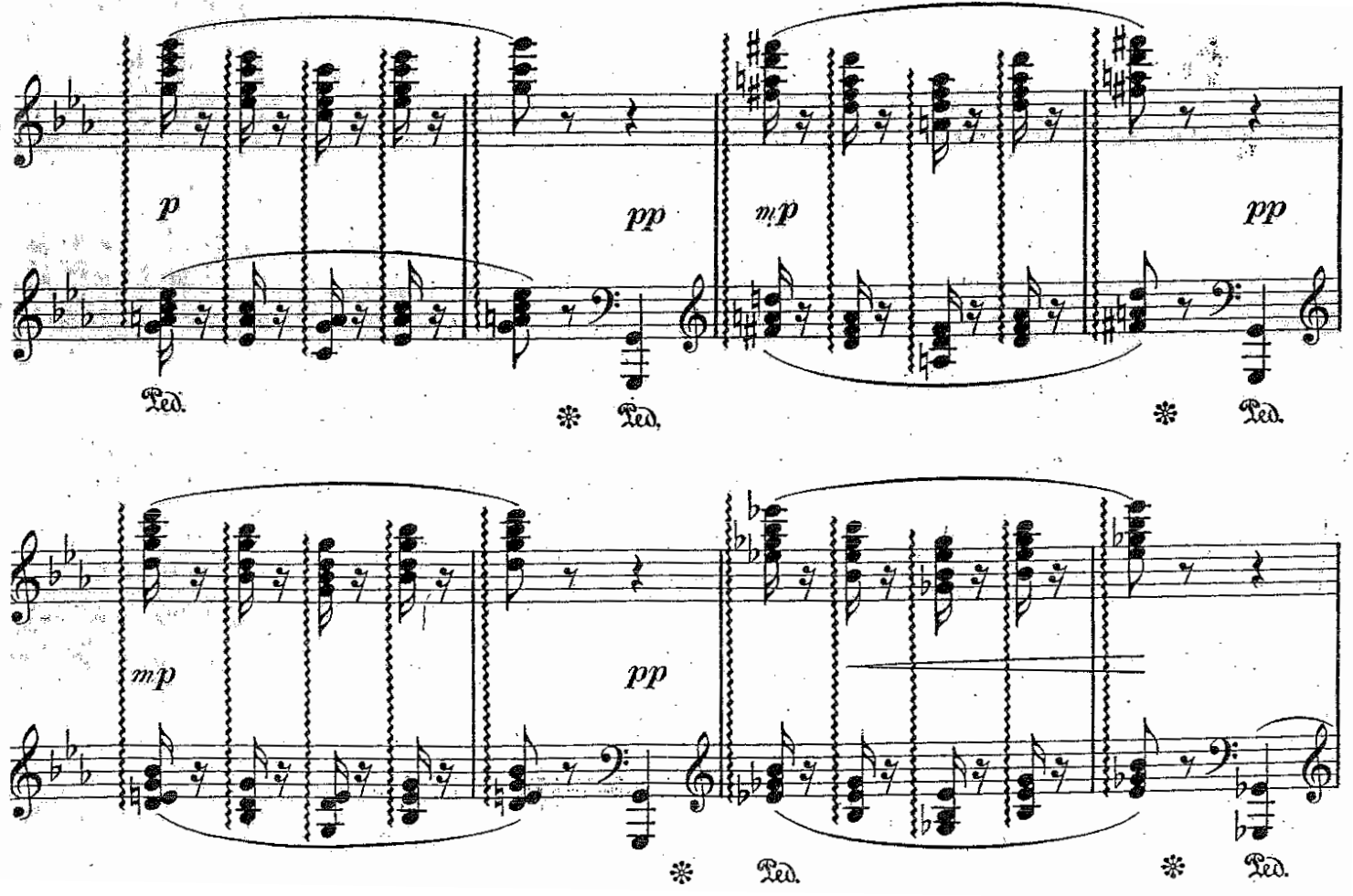

From a structural standpoint, Lang organizes the piece around these two themes.

The opening theme is stated twice in the same guise. The third time it reappears, it resumes without the eight measures of introduction. Instead, Lang reinstates the first two measures of the theme and develops this fragment by using tonic E-flat pedal points followed by a myriad of coloristic harmonies and closes with a coda. Lang successfully creates a coherent whole and imbues the piece with charm and color. Throughout Revery 
as in her other piano works, Lang makes expansive use of detailed expressive markings (example 7.3d)

Example 7.3d Margaret Ruthven Lang: Revery, op. 31, mm. 79-114
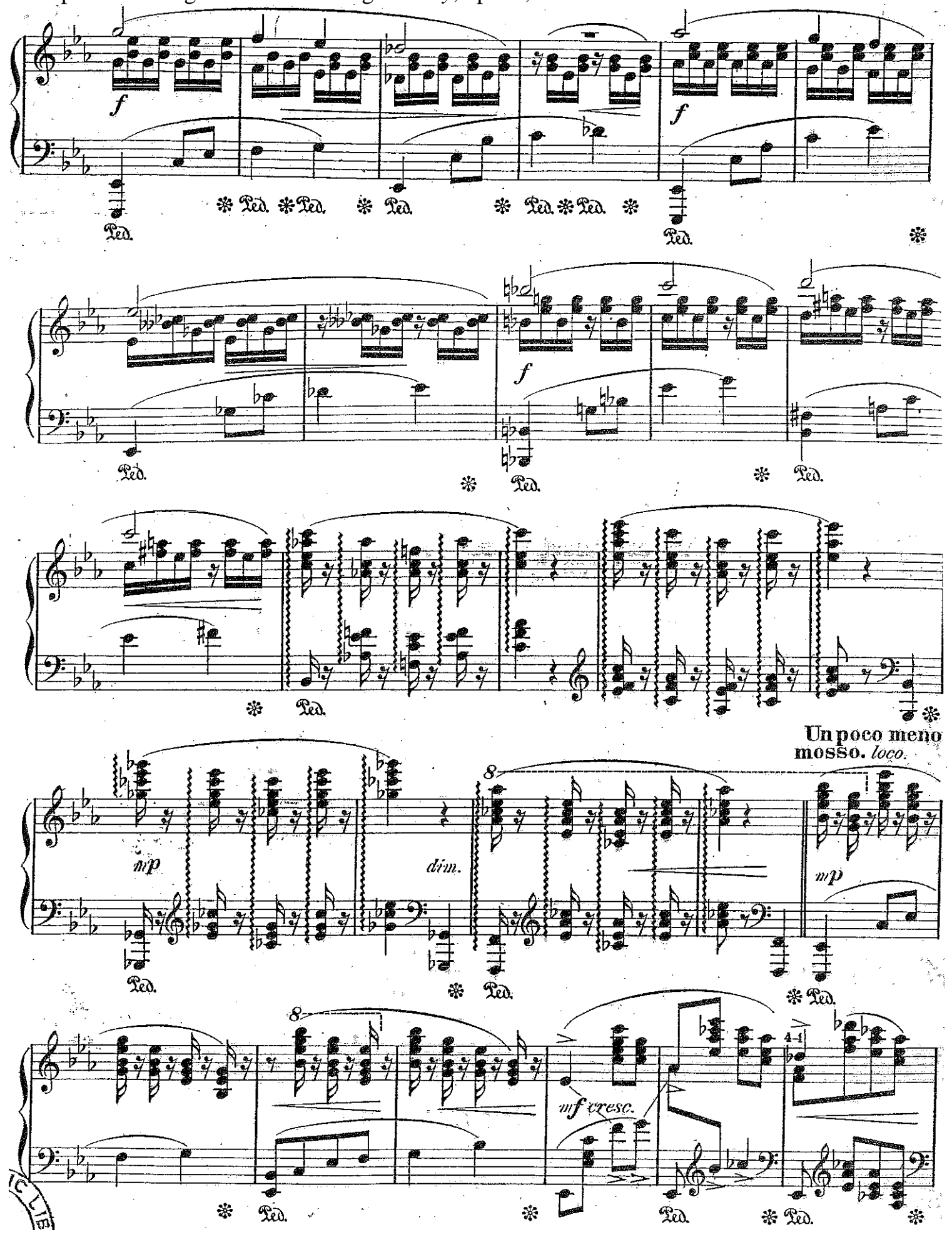


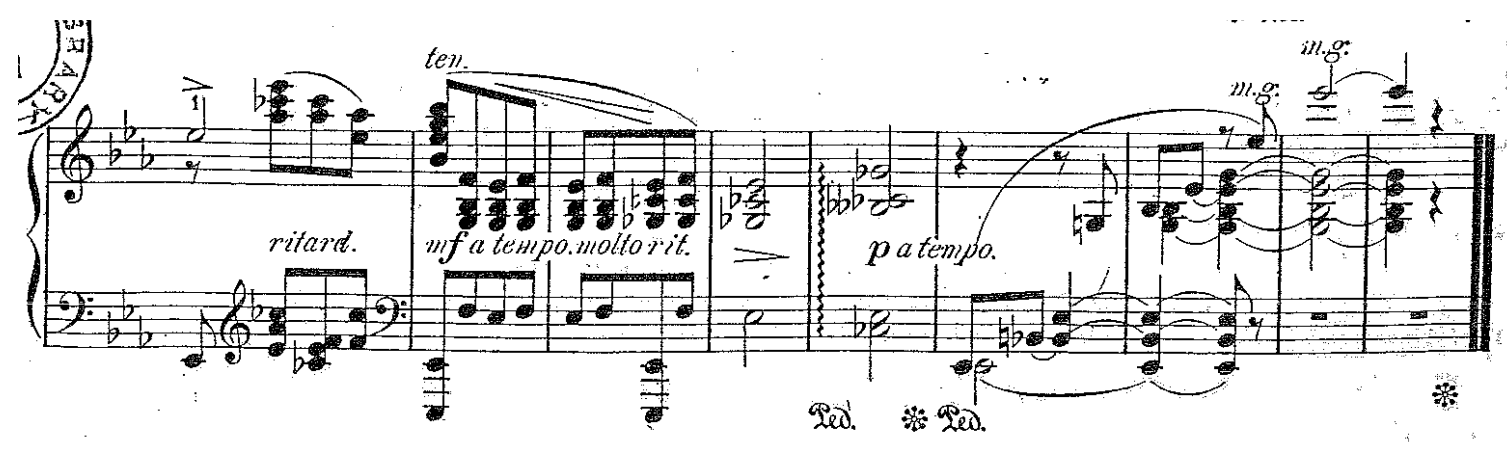

As Hackett mentioned, Revery is more like an etude, albeit a musically substantial one. ${ }^{71}$ The right hand plays the melody with and without the perpetual accompaniment, while the left hand outlines the melody as well. The right and left hands establish a relationship of intertwinement. This beautiful work makes a very good exercise for early advanced students to practice careful listening and control of sound and featuring the melody while balancing the soft perpetual motion of the accompanying figures.

\section{A Spring Idyl, op. 33}

This composition was published together with Revery, op. 31 by the John Church Company in 1899. A Spring Idyl is the last composition that Lang wrote in 1899. She uses a poem by Lizette Woodworth Reese as her inspiration. According to Cline,

"Lang was a discerning critic of literature and made, for the most part, good choices in the poetry she chose to set. She chose the number of women poets, including the poems of Lizette Woodworth Reese, an important transitional poet between the $19^{\text {th }}$ and the $20^{\text {th }}$ centuries." 72

Lizette Woodworth Reese (1856-1935) was an American poet from Baltimore. She served as a school teacher for many years and became a well-known writer in her

\footnotetext{
${ }^{71}$ Mathews, The Great in Music, 281.

${ }^{72}$ Cline, "Margaret Ruthven Lang: Her Life and Songs," 37.
} 
day. Reese's poem "Sweet Weather" describes a pastoral scene and suggests a mood of peace:

"Now blow the daffodils on slender stalks, Small, keen, quick flames that leap up in the mould

And run along the dripping garden-walks:

Swallows come whirring back to chimneys old.

Blown by the wind, the pear-tree's flakes of snow

Lie heaped in the thick grasses of the lane;

And all the sweetness of the Long Ago

Sounds in that song the thrush sends through the rain."

Lang beautifully expresses the pastoral scene and feeling though the piano. She chooses a major key, effective use of contrasting registers of the piano, flexible rhythms in an Andante tempo, and even some American popular song harmonies to depict the nostalgic, sweet feeling of spring. According to Hughes in Contemporary American Composers, he describes A Spring Idyl as "captivating." Meanwhile, Hackett describes A Spring Idyl in The Great in Music as "A pleasant half meditative piece, in a measure not unlike that of a mazurka. The vague impression which the music produces was probably intended as a fit form for voicing the many indefinable emotions which spring awakens in the susceptible breast." 73

Structurally, this piece is written in ABABA form and is set in A-flat Major. The A section is constructed of an eight-measure theme employing hand crossing to the high register of the piano, the single high notes seemingly depicting the spring rain drops. The B section begins in measure 15 in the Eb, with a syncopated rhythm that becomes the accompanying figure for the second theme beginning in measure 19. In the subsequent return of A and B, Lang makes good use of altering the themes with passagework

\footnotetext{
${ }^{73}$ Mathews, The Great in Music, 281.
} 
depicting the gentle wind, full chords and varied harmonies. The last three bars, a short coda, provide a final gesture of fluttering spring breezes (example 7.4a).

Example 7.4a Margaret Ruthven Lang: A Spring Idyl, op. 33, mm. 1-67

\section{A Spring Idyl.}

Slow blew se daffosits on deeder ctalks,

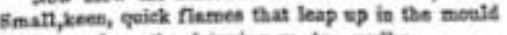
And ras along the dripping garden-walket

Swallows eeme whirrieg buck to clitmneys old.

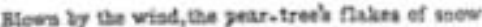
tio heapes to the thick grasses of the lase;

Asd all the swectaess of be Long Ago

Seunds is that song tho terush seceds tarnagh the rala.

L. W. REBSE. *

Margaret Rutuven Lasc. Opus 33.
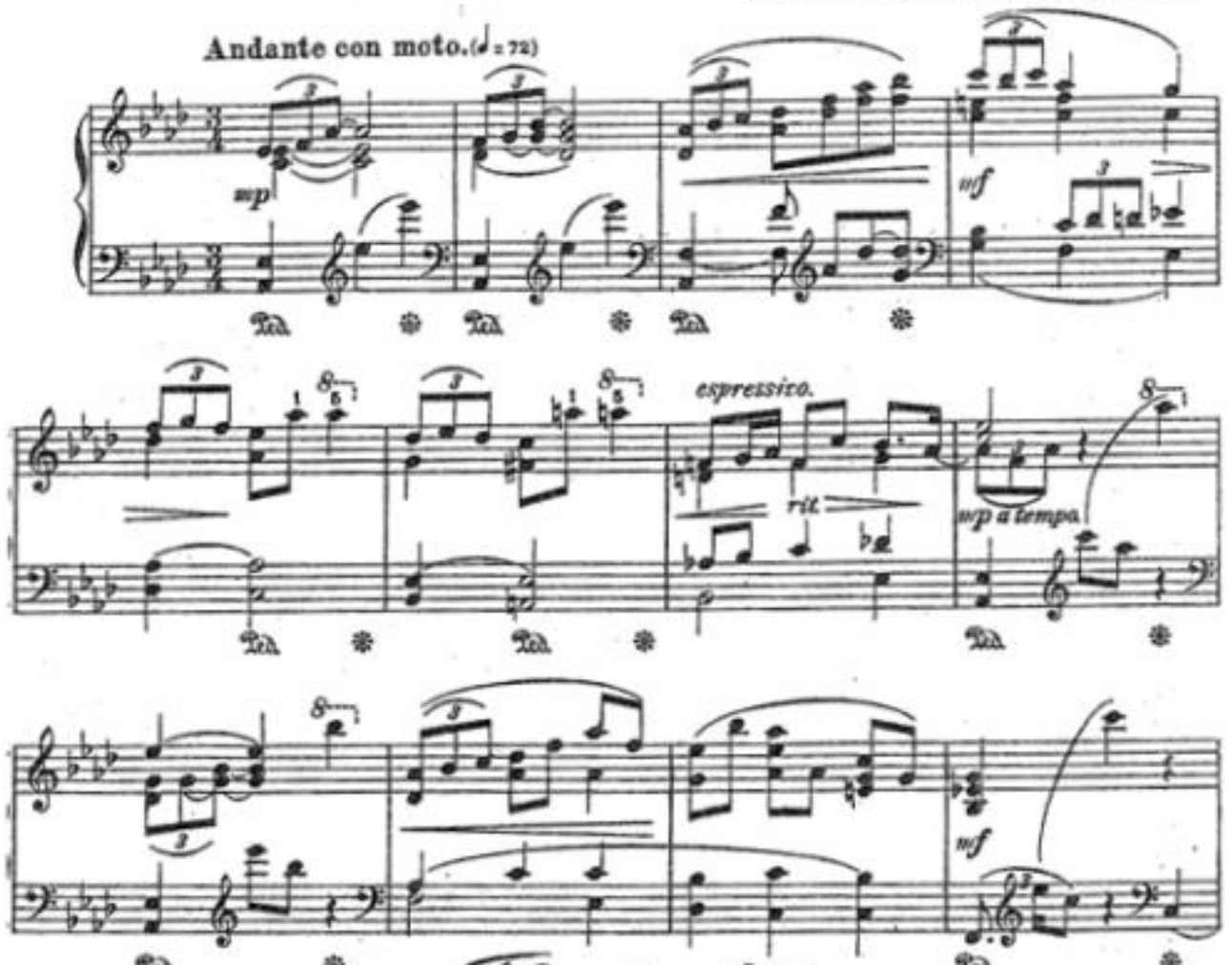

sa

起
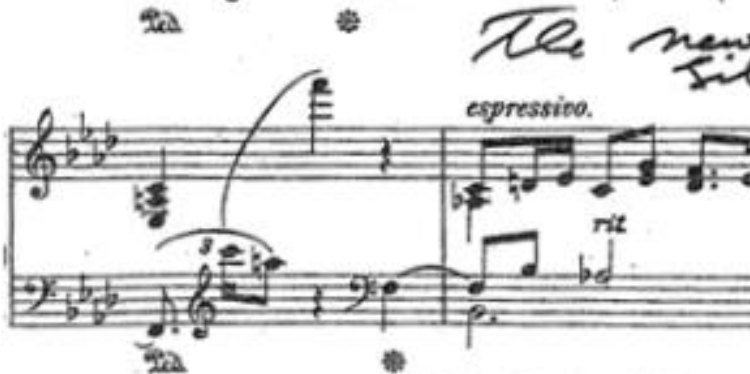

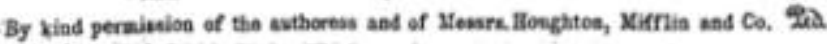

色.

Ougyright MDCecxcIX by tha Jahn Chweth Campany. Intarsatianal Capytoht.

Eatered aceenting to ad of the Fatlinent of Casuds ia the year MDCcexeDX

$13168-4$

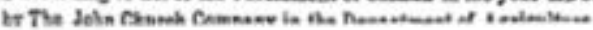



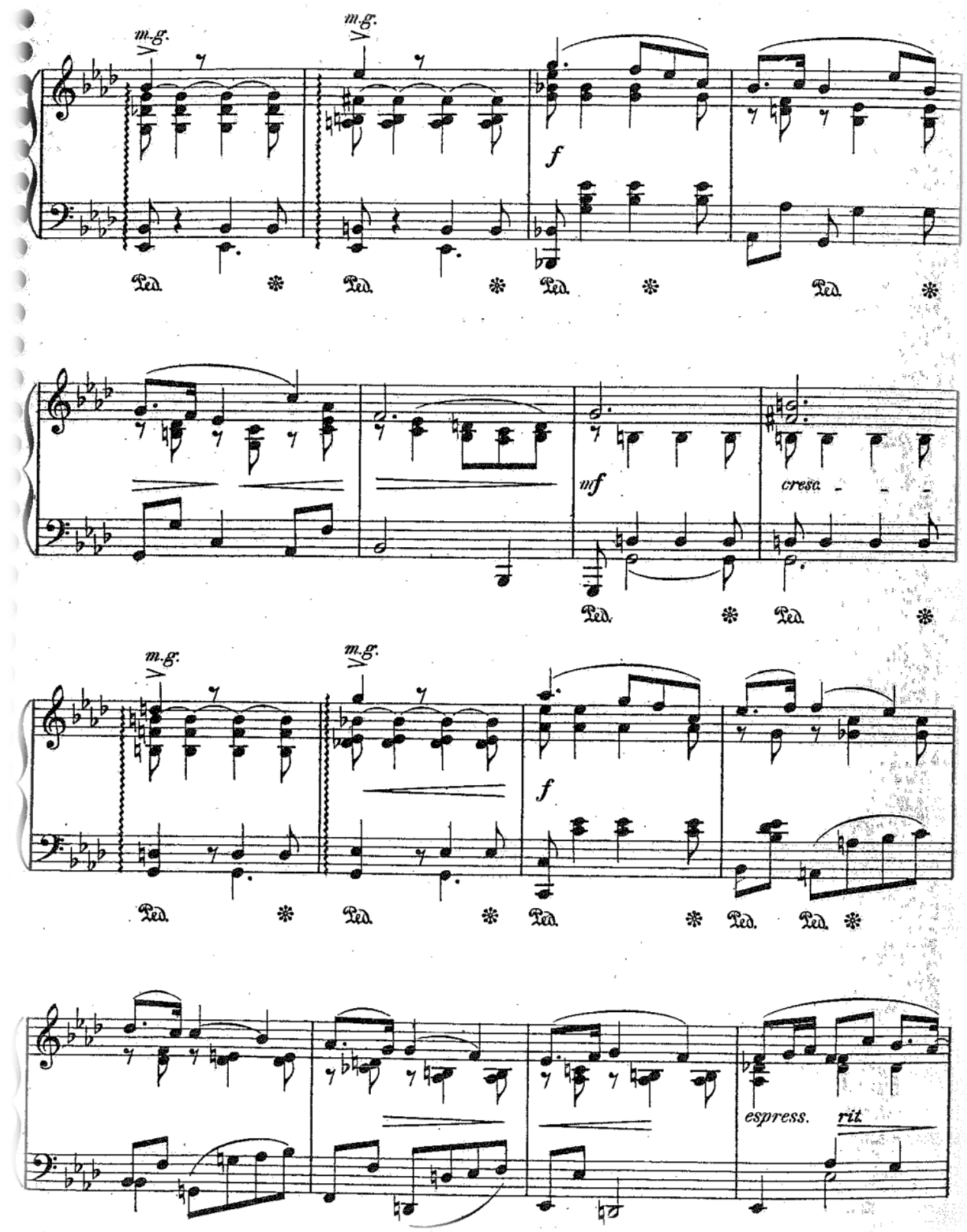

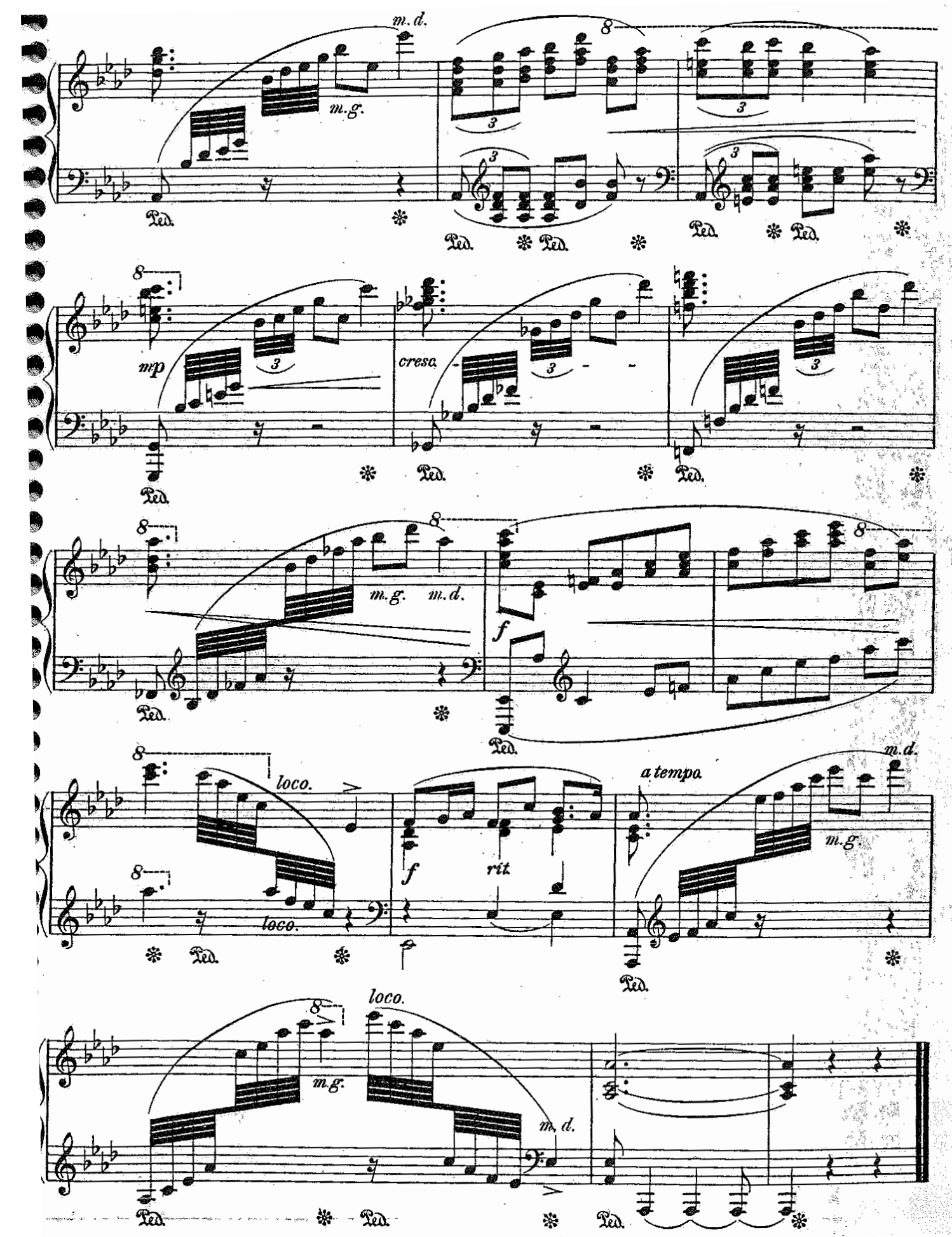
This piece is suitable for late intermediate to early advanced level students. The technical challenges include the smooth hand crossings; clear pedaling; fast, even passagework; the lyrical full chords in the triplet rhythms and the overall subtlety and nuance of sound required throughout. 


\section{CHAPTER VIII}

\section{THE SPIRIT OF THE OLD HOUSE, OP. 58}

The Spirit of the Old House: Elegy for Piano, op. 58, was published in 1917 by A. P. Schmidt. It is one of the last three works that Lang composed. This is her first return to composing for the piano after an 18-year hiatus. Lang's inspiration is an excerpt from the collection The Time of Roses by John Vance Cheney:

Forever from the unforgetting skies

Downward she looks with all the eyes

Once lifted to her, yearning so,

In the sweet evening long ago.

According to Cline, “[o]ne of Lang's favorite poets, judging by the number of times she chose his poetry to set, was John Vance Cheney." ${ }^{, 74}$ In addition to using his work in The Spirit of the Old House, Lang used his poems in seven songs and two works for women's chorus. ${ }^{75}$

John Vance Cheney (1848-1922) was an American poet, essayist, and librarian.

He was educated at Temple Hill Academy in Geneseo, N.Y. After a short period of teaching and of practicing law, he became the librarian of the Free Public Library of San Francisco and held this position from 1887 to 1894 . In 1894 he moved to Chicago, where he accepted a similar position at the Newberry Library, and where he remained until1899. ${ }^{76}$ In 1909 , he moved to San Diego upon his retirement. Cheney was a regular contributor to major literary magazines, including The Century, The Atlantic

\footnotetext{
${ }^{74}$ Judith Ann Cline, "Margaret Ruthven Lang: Her Life and Songs." (D.M.A. diss., University of Miami, 1993), 58.

${ }^{75}$ Cline, "Margaret Ruthven Lang: Her Life and Songs," 64.

${ }^{76}$ Quoted in "John Vance Cheney," http://www.poetry-archive.com/c/cheney_john_vance.html (accessed February 23, 2013, 2009). Jessie B. Rittenhouse, "from The Little Book of American Poets: 1787-1900," Cambridge: Riverside Press, 1915.
} 
Monthly, New England Magazine, and Harper's Monthly. His collected works from the period 1887 to 1922 fill eight volumes. ${ }^{77}$

Lang's writing is so descriptive that it seems possible to associate the lines of the poem with the actual phrases of the piece. Here, she seems to be using text painting, as in an art song. In terms of structure, the piece is cast in ABACA form. Because the title of the piece suggests an elegy and the text refers to a time "in the sweet evening long ago," one may assume this work is inspired by this pensive, nostalgic poem. The sense of looking back and the memory that keeps coming back are reflected by the use of a miniature rondo form, with its repeated returns of the A section.

The opening theme appears three times in three different keys, and with each appearance it is transposed a third lower. Lang opens this piece with the phrase that suggests the opening line of the poem, "Forever from the unforgetting skies" with the repetitive motives. $\mathrm{A}^{1}$ starts with a $\mathrm{C}$ augmented dominant, with a major $7^{\text {th }}$, and suspensions that resolve with only glimmers of the major tonal key in the theme, F major. Then, it is followed by a descending line to reflect "from the skies" and to stress "unforgetting." Lang repeats the melody from mm. 5-6 (soprano) in mm. 7-8 (alto) and here, the subject is accented (example 8.1).

${ }^{77}$ Wikipedia, "John Vance Cheney," Wikipedia the Free Encyclopedia, http://en.wikipedia.org/wiki/John Vance Cheney (accessed February 26, 2013) 
Example 8.1 Margaret Ruthven Lang: The Spirit of the Old House, op. 58, mm. 1-11
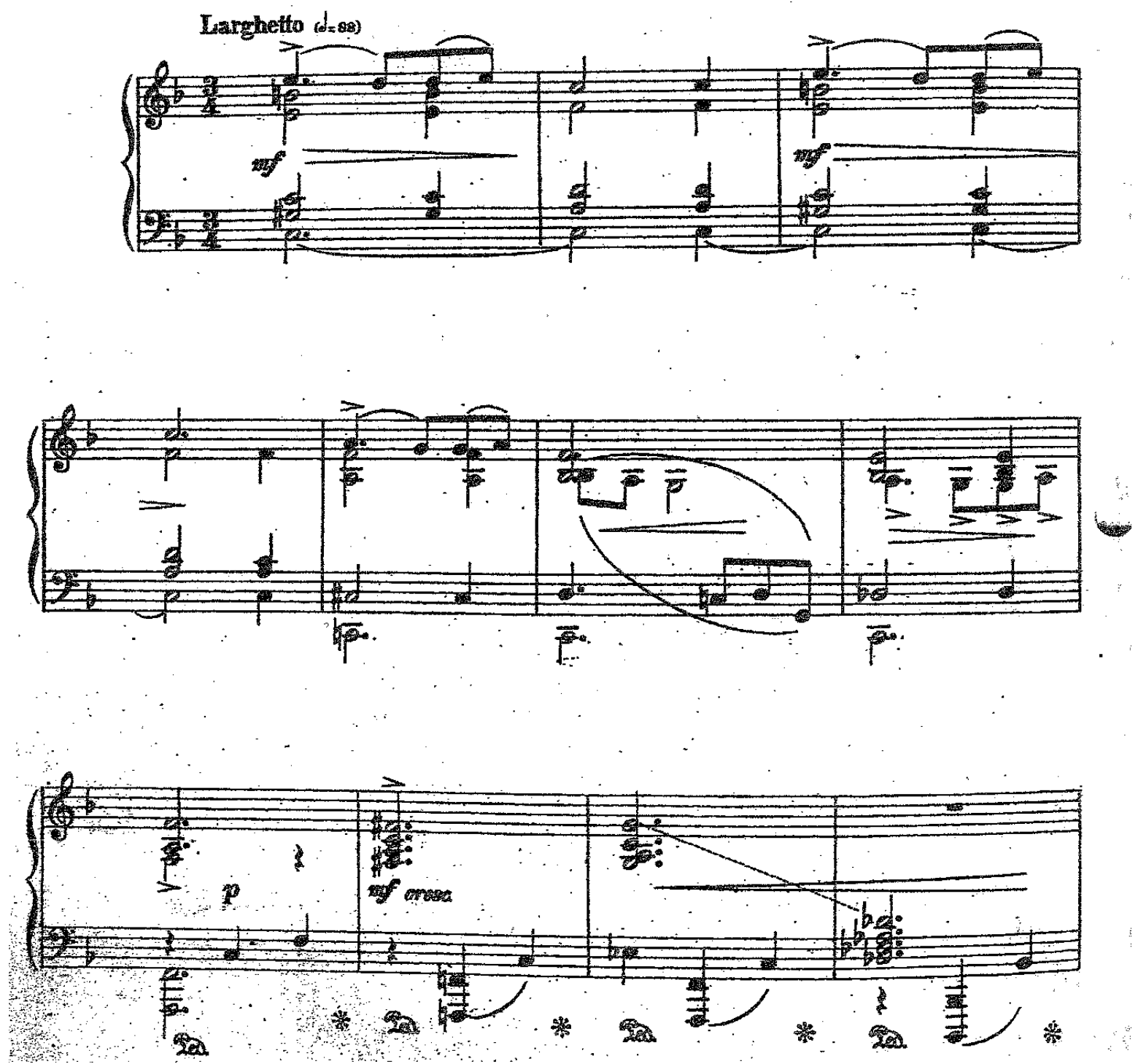

The second line of the poem, "Downward she looks with all the eyes," seems to coincide with $\mathrm{A}^{2}$ a third down from the original theme, with an A-flat dominant augmented seventh chord to describe "downward." In addition, this subject is followed by a downward passage (example 8.2). 


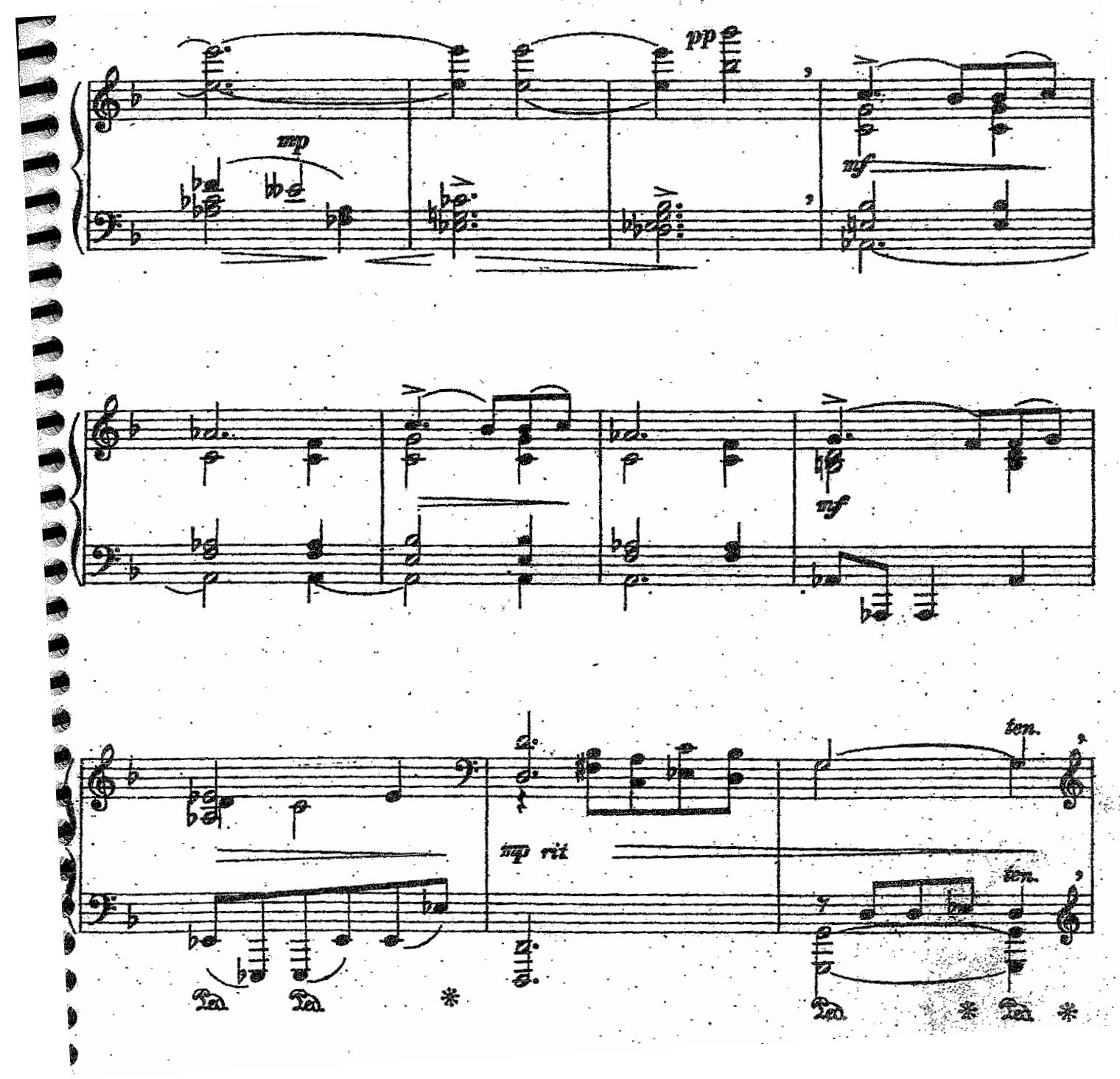

Also, the right hand in mm. 24-26 plays in a low register. In m. 24, it might be that Lang is trying to show "with all the eyes" through the E-flats in the low register in the left hand (example above). The third line of the poem, "Once lifted to her, yearning so," starts in the C section, which is the emotional outpouring section as well as the climactic passage. It starts out with an espressivo buildup shown by the use of thicker texture, dynamic reinforcement, an ascending line in the left hand that creates drama, and 
chromatic harmony that creates intensity. The outpouring section happens in mm. 31-36 (example 8.3).

Example 8.3 Margaret Ruthven Lang: The Spirit of the Old House, op. 58, mm. 27-38
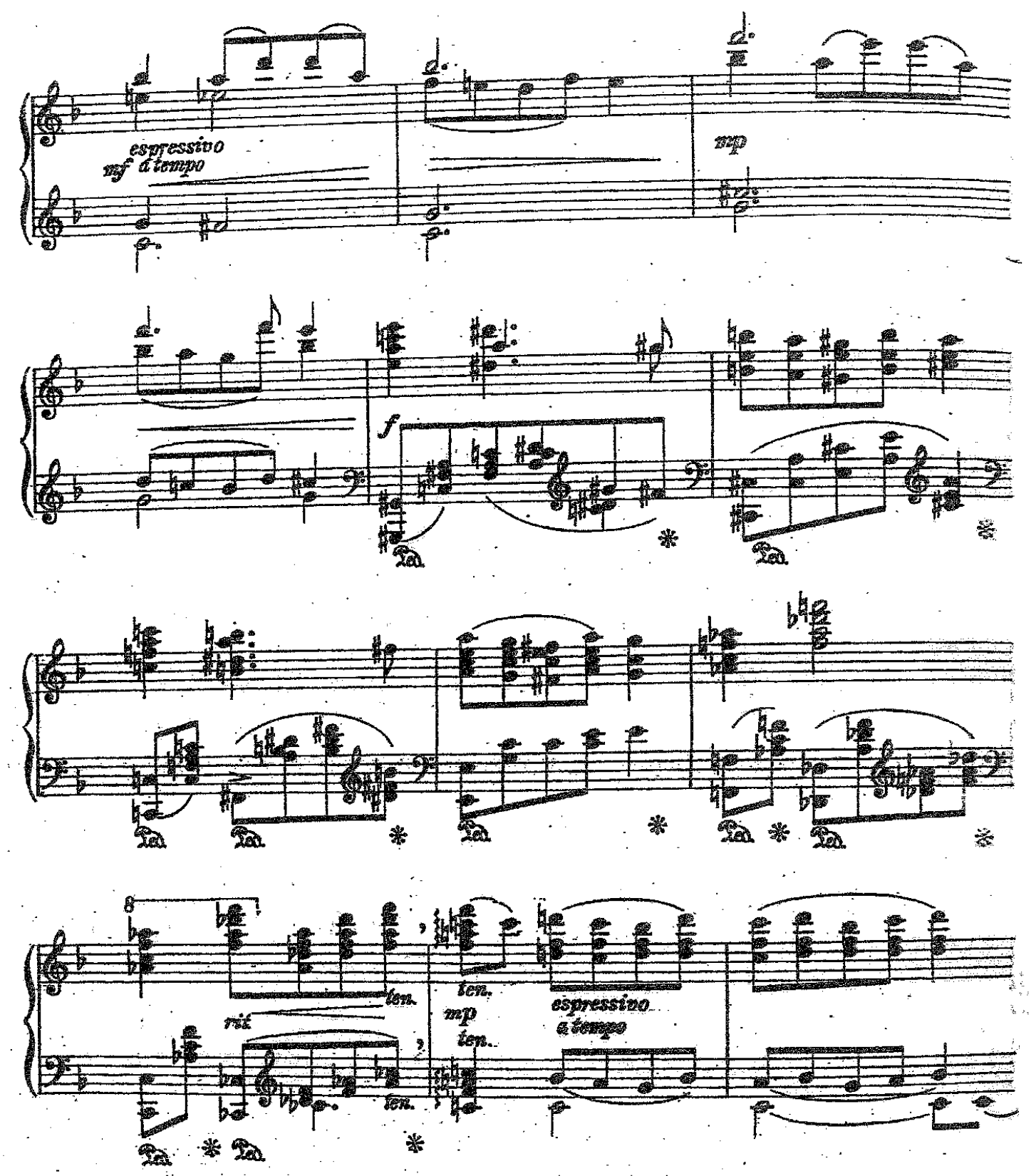

Finally, the first solid $\mathrm{A}^{3}$ appears in an F-sharp augmented dominant chord a third down from $\mathrm{A}^{2}$ and is followed by the "lifted" passage, an octave higher in both hands, mm. 47-50. This "lifted" passage is adapted from the section C in mm. 37-40 marked 
expressivo, which also suggests "yearning so" by treasuring the previous passage, a sense of longing for the past (example 8.4).

Example 8.4 Margaret Ruthven Lang: The Spirit of the Old House, op. 58, mm. 36-42
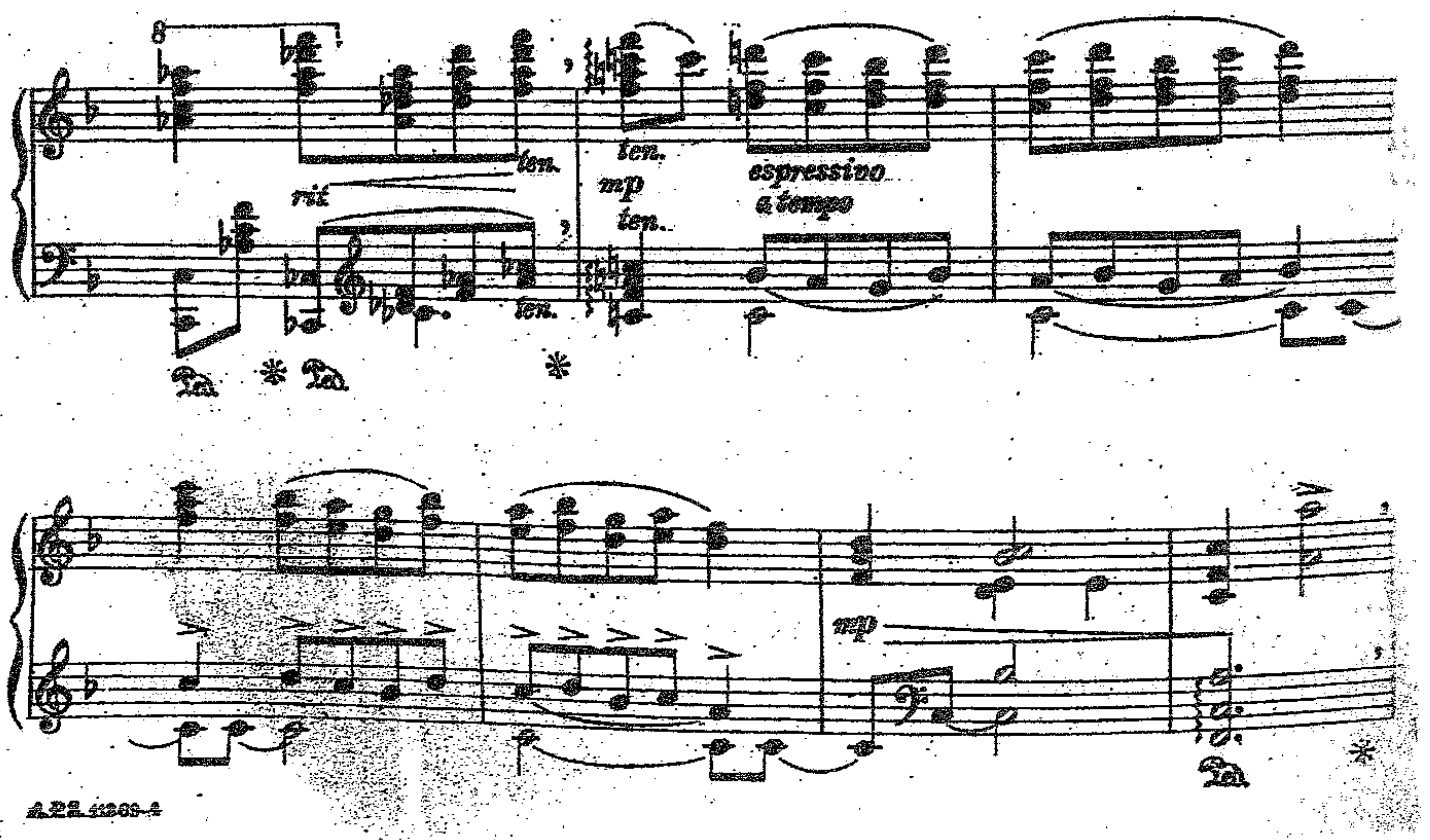

The urgency of the strong feeling towards something that is unattainable and a mixture of past and present emotion is exposed by the use of big leaps from the high to low and back to high register; the latter two are marked with accents. Next, a sigh is shown by the sudden silence on the main beat in $\mathrm{m}$. 51, for the first and only time in this music. The feeling of letting go may seem hard, and it is presented by a dominant both in pedal point and the so-called heartbeat figure on the left hand octave in mm. 52-56. This dominant statement needs a resolution, and from measure 53 onward, Lang's marking, "steadily, to the end," is precisely describing the resumption of a stable frame of mind in a timely manner. This statement is shown by the first appearance of the tonic $\mathrm{F}$ in the bass with the suspension chord and resolved with a solid F Major chord in the right hand in $\mathrm{mm} .53-56$, accompanied by the heartbeat figure in the left hand in $\mathrm{mm} .54$ and 56. 
The last line of the poem, "In the sweet evening long ago" (mirrored by the coda, "sweet evening" with low F and an F Major chord), is clearly key-oriented and provides a sense of settling down to a final rest in the chosen tonality, F Major. It is closed with a sweet tune marked espressivo in the left hand and held for three measures of dotted half-note ties (example 8.5).

Example 8.5 Margaret Ruthven Lang: Revery, op. 31, mm. 43-68
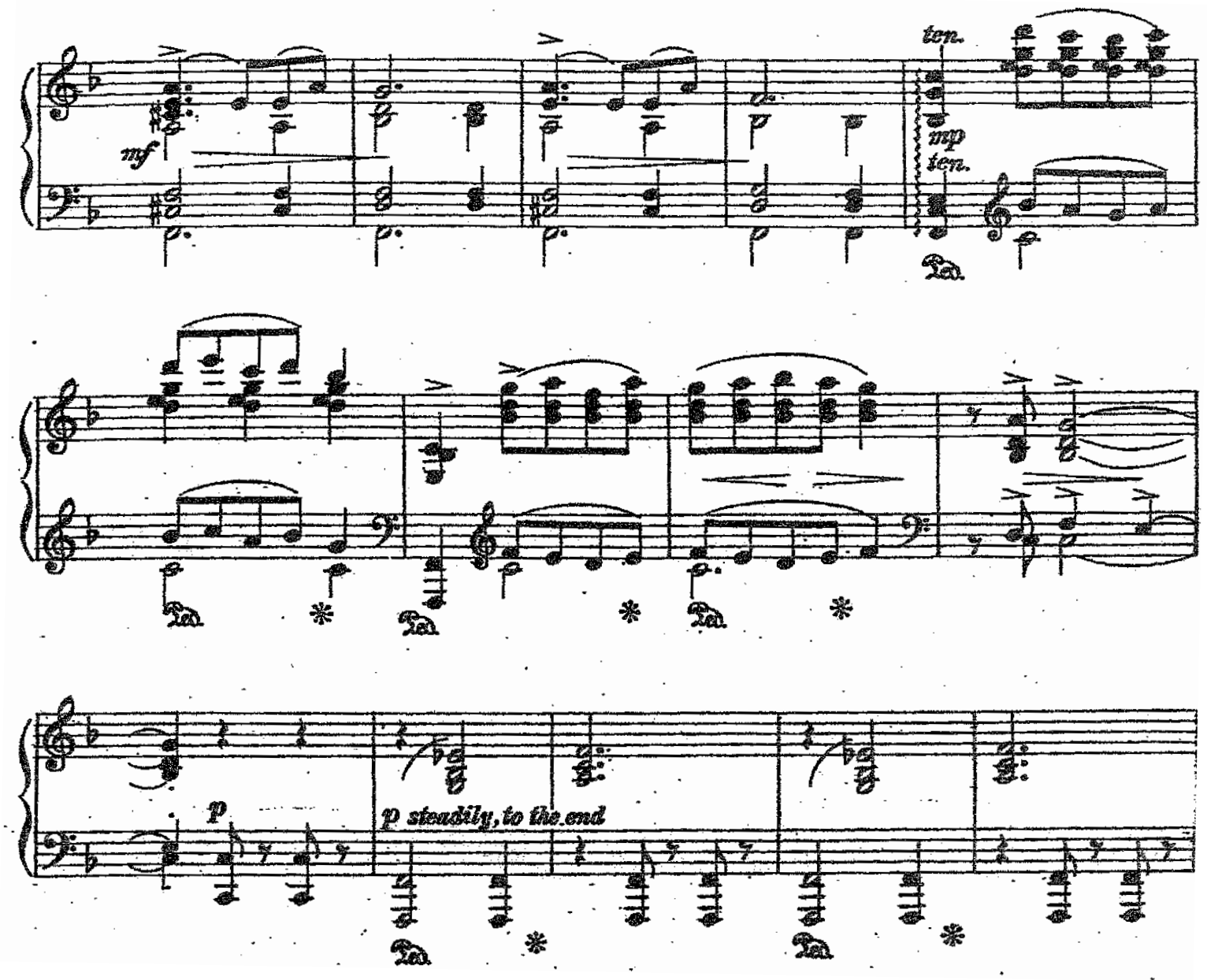


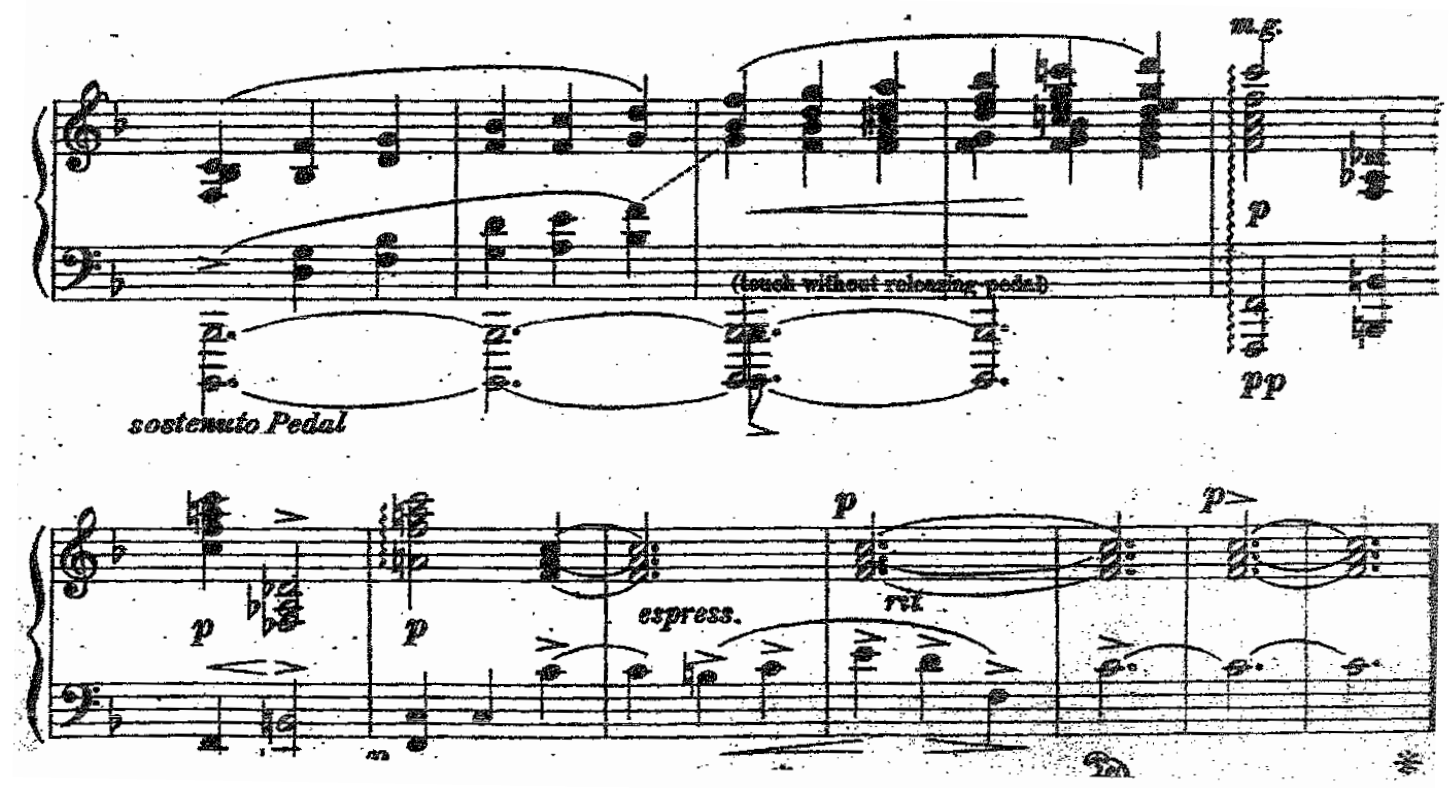

Lang experiments with harmony here and heightens the expression by chromatic alterations, chromatic chords, seventh chords, and chordal shifts over the interval of a third. Lang uses many pedal tones to create a coloristic effect.

This piece is suitable for late intermediate and early advanced students. It covers a wide range and bigger hands are needed to reach the octaves, especially in the $\mathrm{C}$ section. There are a few interesting pedagogical features. First, Lang indicated the use of the sostenuto pedal in mm. 57-60 and instructed the player to restrike the chord in $\mathrm{m} .59$ without releasing the pedal. The work also calls for a wide range of dynamics with Lang's detailed expressive markings and a more mature musical expression (example 8.6) 
Example 8.6 Margaret Ruthven Lang: The Spirit of the Old House, op. 58, mm. 57-61

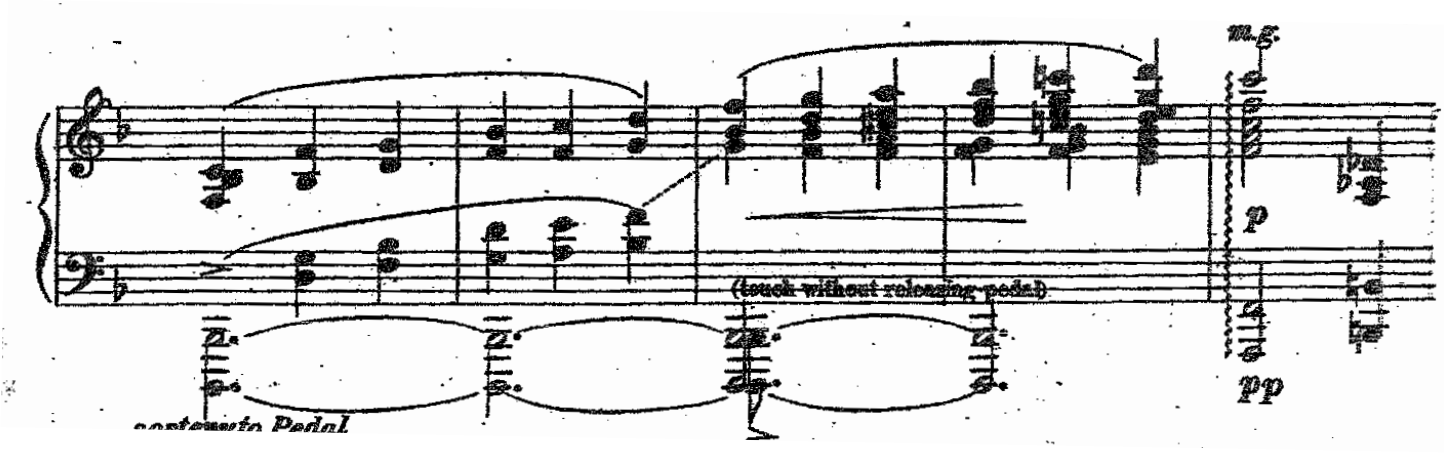




\section{CHAPTER IX}

\section{FINAL PIECES FOR CHILDREN}

In 1919, a year after the end of World War I, which was also her last year as a composer, Lang wrote her final sets of character pieces: One Summer Day, op. 59, and Three Pieces for Young Players, op. 60; both were published in the same year by

Theodore Presser. According to Cline,

These pieces are listed in the holdings of the British Public Library and have not been cited in any other contemporary source. They are as follows: One Summer Day, op. 59 (Theodore Presser, 1919); and Three Pianoforte Pieces for Young Players, op. 60 (Theodore Presser, 1919). In a New York Manuscript Society list of works by Margaret Ruthven Lang, Lang added op. 59 under the heading of pianoforte solos, but then named it Suite for Young Players. ${ }^{78}$

Furthermore, they were composed on the tenth anniversary of her father's death; one may see that these pieces were sets of nostalgic compositions that remind her of her childhood, when she started to study piano with her father. In a sense, they are her "Albums for the Young".

\section{ONE SUMMER DAY, OP. 59}

One Summer Day is a set of five character pieces, each with a descriptive title. Lang draws inspiration from describing the activities of people during the summer. They are suitable either for performance as a set or for use as separate teaching pieces for the late elementary or early intermediate student. Each movement is discussed in turn.

\footnotetext{
${ }^{78}$ Cline, "Margaret Ruthven Lang: Her Life and Songs," 58.
} 


\section{Hide and Seek in the Barn}

This work is in simple duple meter, and the form is ABA followed by a coda. The joyful mood is shown by the use of D Major, bright rhythms and crisp articulation. This piece includes Lang's description, “On Tip-toe” written within the score. Lang tries to portray the hider's tip-toeing through the use of staccato in the left hand against the legato in the right hand in $\mathrm{mm} .1-8$. In mm. 9-16, the melody shifts to left hand to represent the other role, that of the seeker. The melody is mostly accented, and the dynamic is mezzo forte. This presents a different character from that of the hider.

In the B section, mm. 17-24, Lang mixes the staccato and the accents in the melody to represent the anxious hider and the excited seeker. In the last two measures, mm. 23-24, the melody changes from left to right; this describes the seeker finding the hider, and then they switch roles, as marked by the return of the A section (example

\subsection{1a).}

Example 9.1.1 a Margaret Ruthven Lang: One Summer Day, op. 59 no. 1, mm. 1-24
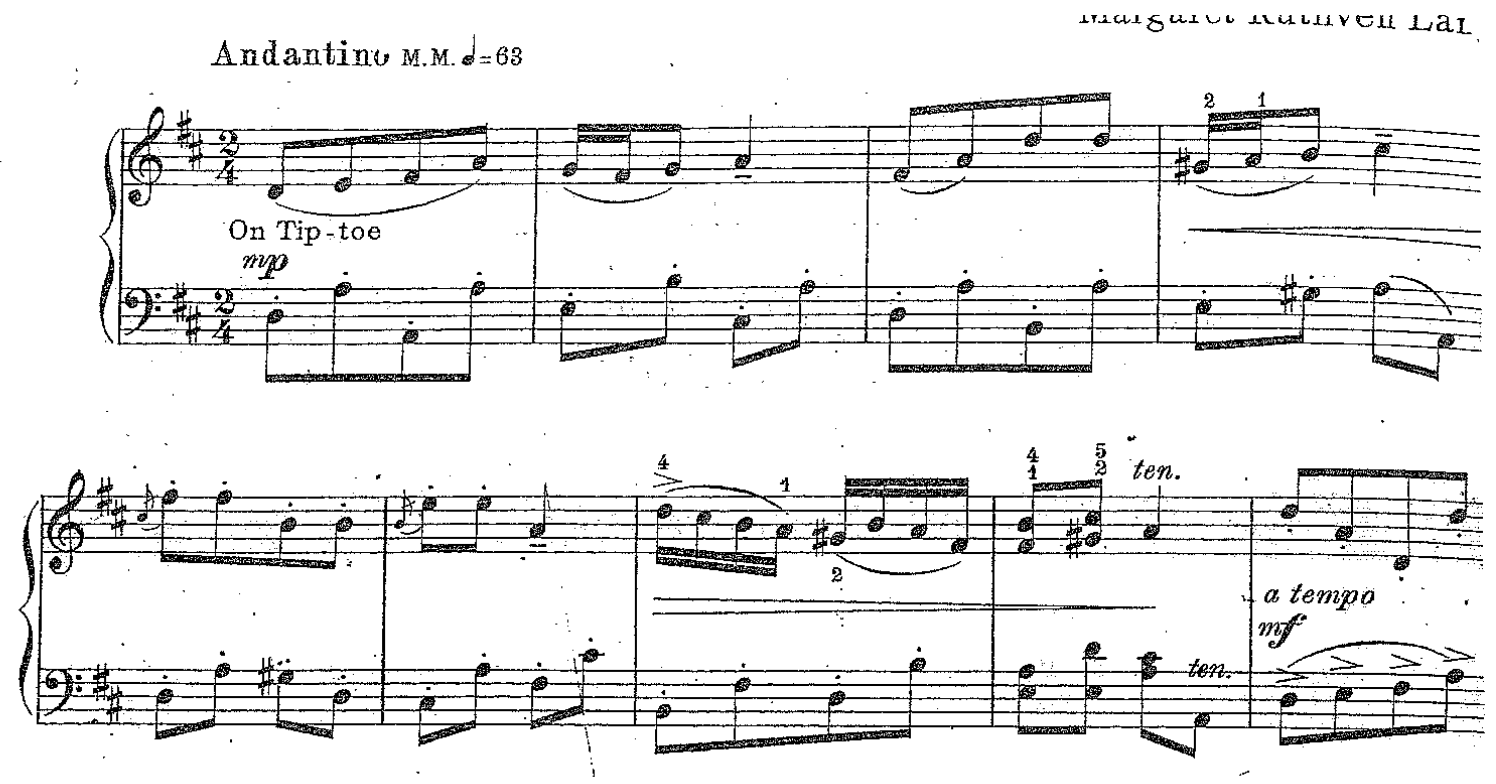

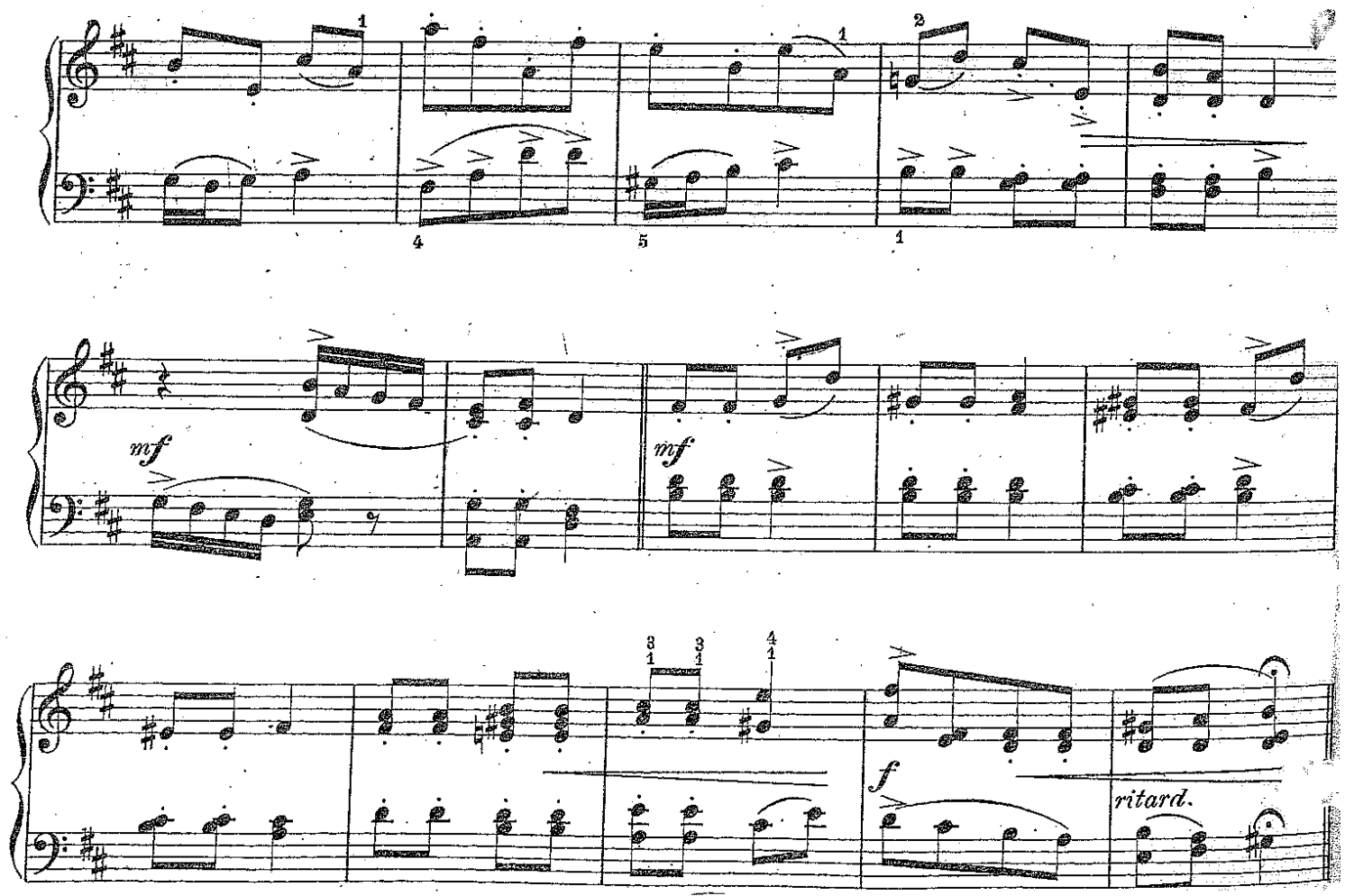

The passage below shows one of Lang's clever ideas; she layers the subject every time it comes back (example 9.1.1b)

Example 9.1.1b Margaret Ruthven Lang: One Summer Day, op. 59 no. 1, mm. 25-34
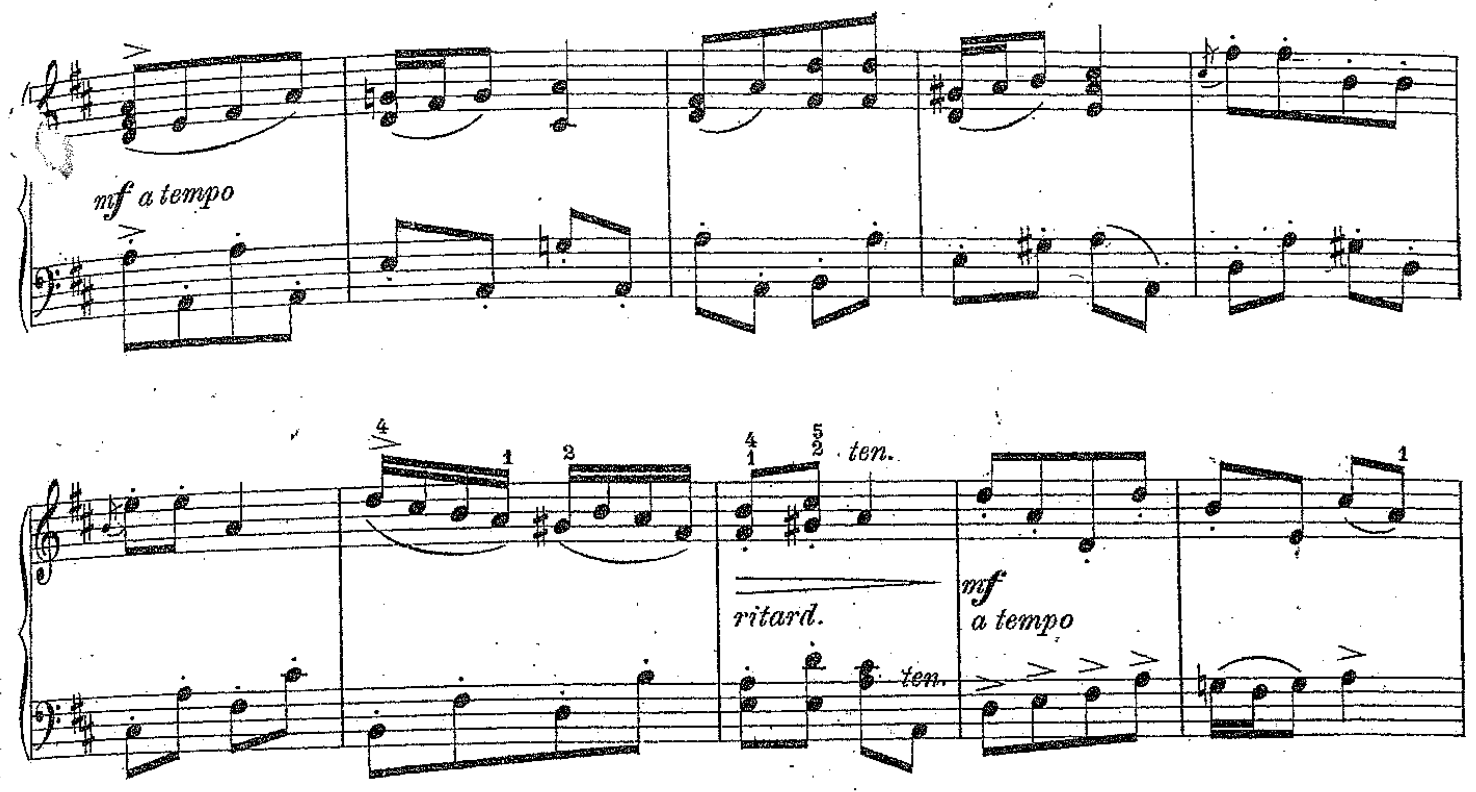

This movement ends with a coda (example 9.1.1c). 
Example 9.1.1c Margaret Ruthven Lang: One Summer Day, op.59 no. 1, mm. 40-60
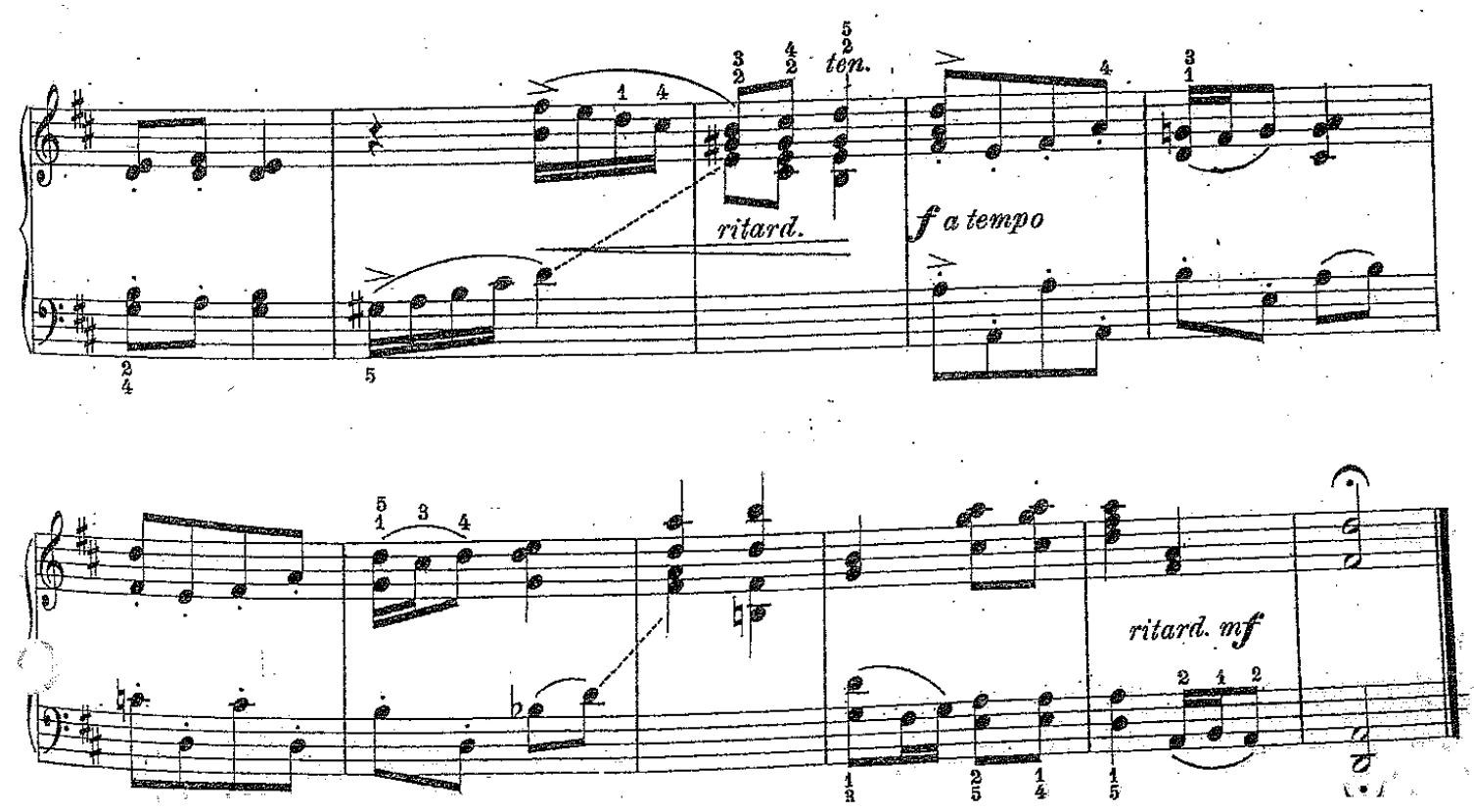

This is a good exercise for practicing articulation (staccato against legato and slurs), playing melody with the left hand (which is always a challenge for a pianist), and voicing (the melody shifts in mm. 23-24 from the left hand to the right hand). It captures the joyful childhood game of Hide and Seek perfectly.

\section{Morning Lessons}

The key of this song is G Major, and the beautiful opening melody beginning on high $\mathrm{G}$ sets the morning mood. Lang's creativity in layering subjects shows in this song; she constructs it from a two-measure theme. Based on the single opening theme each time it appears, it is layered in a different texture, with voicing as shown in mm. 9-12 and mm. 13-16 (example 9.1.2a). 
Example 9.1.2a Margaret Ruthven Lang: One Summer Day, op. 59 no. 2, mm. 1-21
No 1604
Morning Lessons

Moderato M.M. $\delta=76$

Margaret Ruthven La
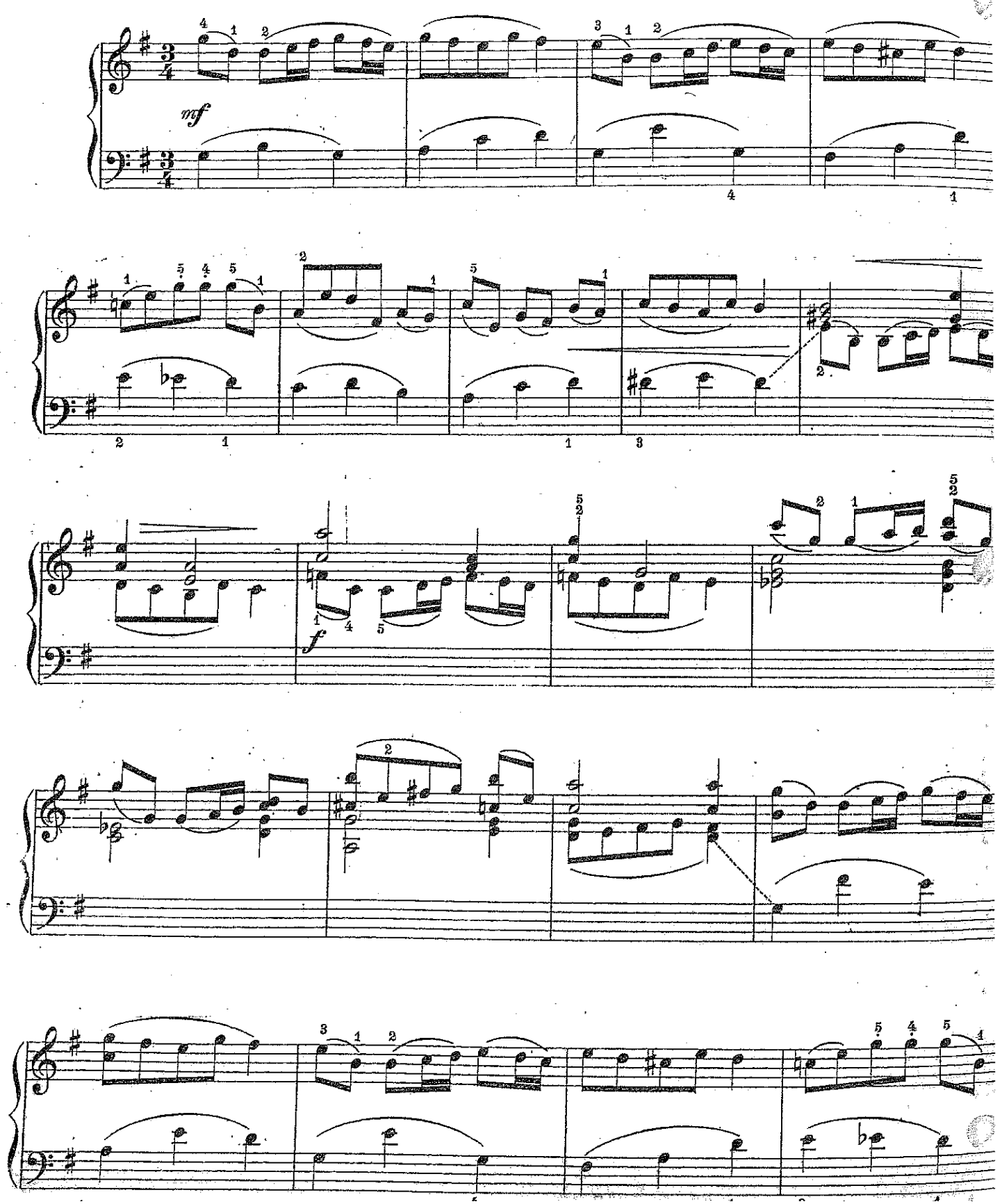
This delightful piece is an opportunity for students to develop skills in articulation such as the two-note slur, lifting of phrase ends gracefully, overall legato and melodic shape.

\section{Picnic in the Woods}

This is a small charming piece in B-flat Major. The piece is in simple triple meter and again requires much attention to details of phrasing and articulation. Lang also makes an interesting use of different registers throughout the piece, requiring the students to read the left hand in both clefs (example 9.1.3a).

Example 9.1.3a Margaret Ruthven Lang: One Summer Day, op. 59 no. 3, mm. 1 - 19

$$
\text { No } 16045
$$

\section{Picnic in the Woods}

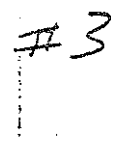

With expression M.M. $=106$
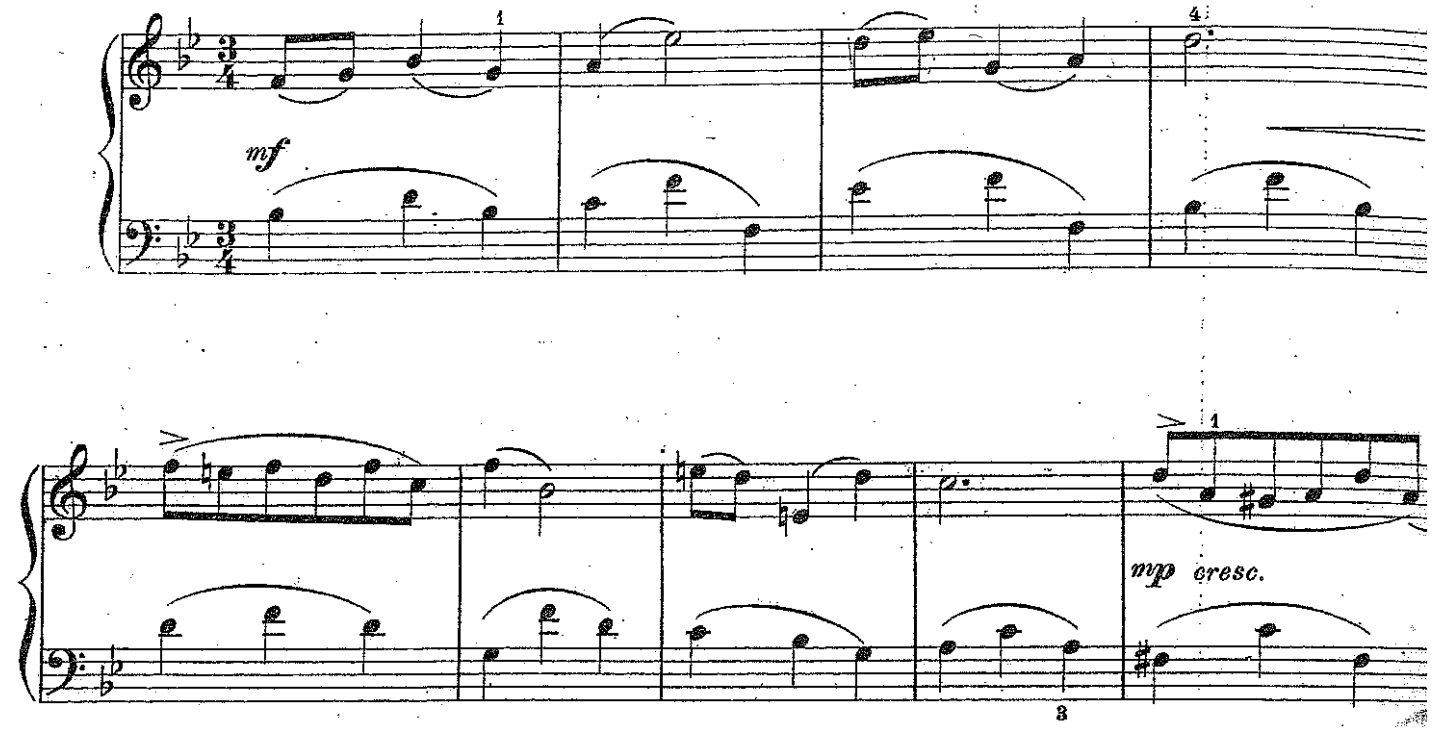

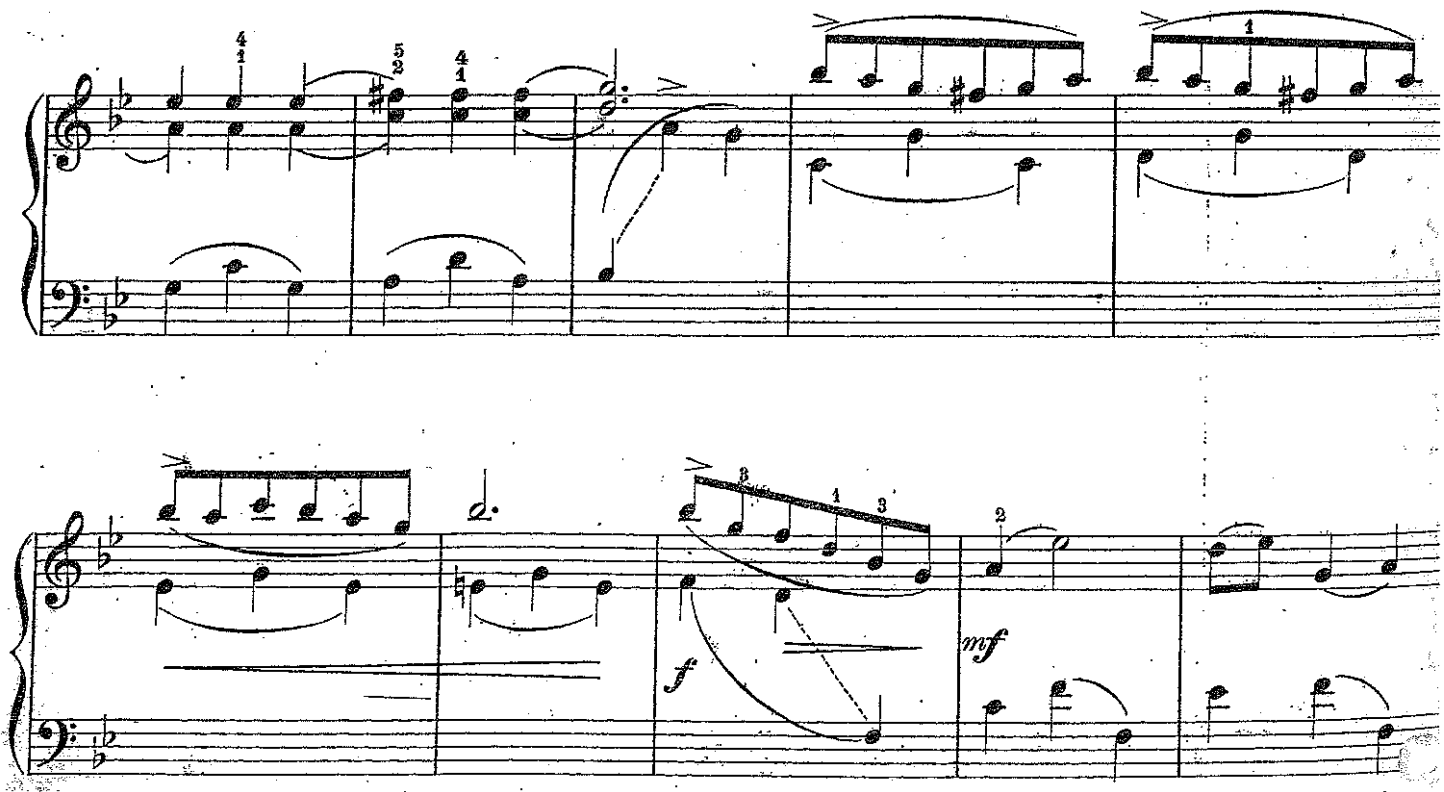

\section{Knitting for the Soldiers}

This beautiful piece is the longest one in this set; it is reminiscent of Schubert's Gretchen am Spinnrade, op. 2, D. 118. Lang composed this piece in d minor, the same key Schubert used for his Gretchen am Spinnrade, and both have a repetitive motion and similar sense of longing. Lang uses the form ABA'. The constant syncopated eighth-note accompaniment mimics the repetitive motion of the knitting. In Schubert's song, the spinning of the wheel is shown in the right hand (example 9.1.4a).

Example 9.1.4a Franz Schubert: Gretchen am Spinnrade, op.2, D. 118, mm. 1-12

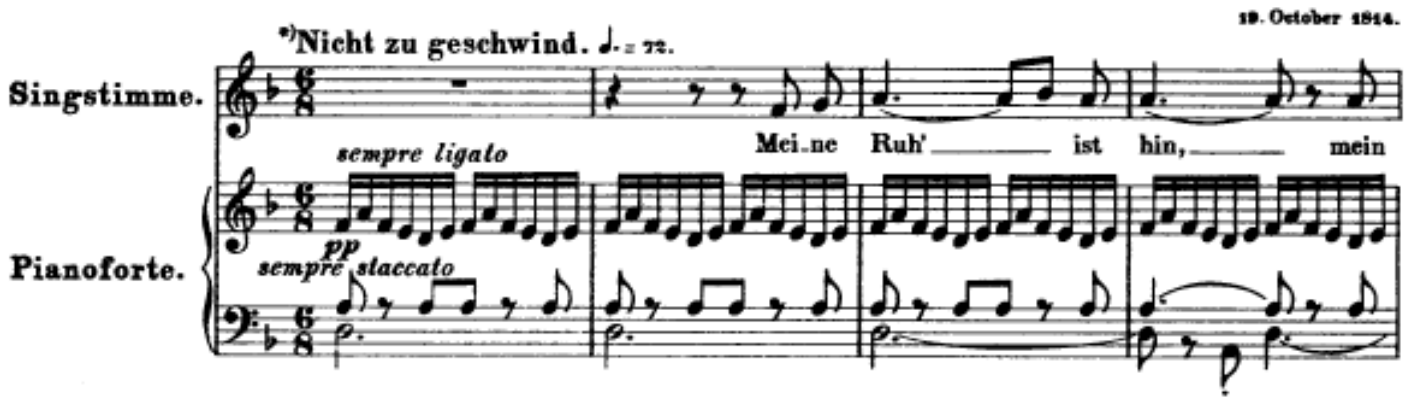



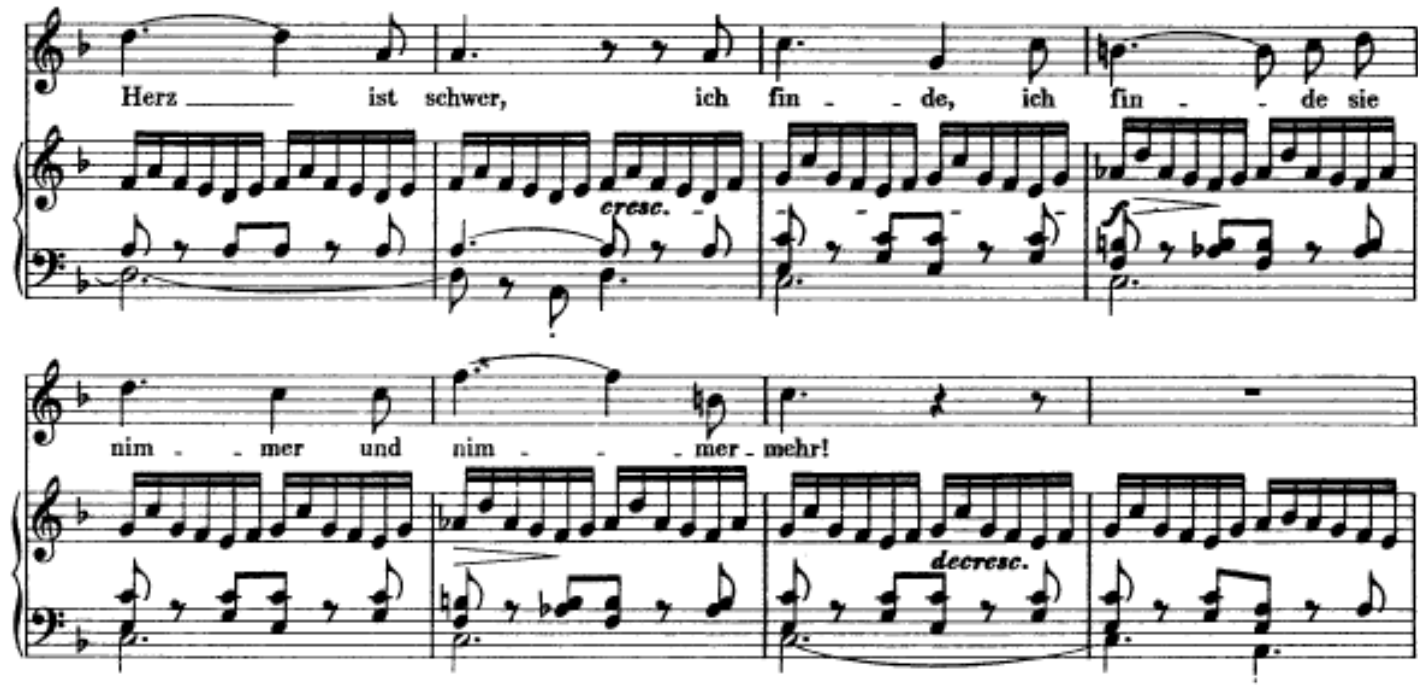

Example 9.1.4b Margaret Ruthven Lang: One Summer Day, op. 59 no. 4, mm. 1-18

Steadily and quietly M.M.d $=69$

Margaret Ruthven Lang
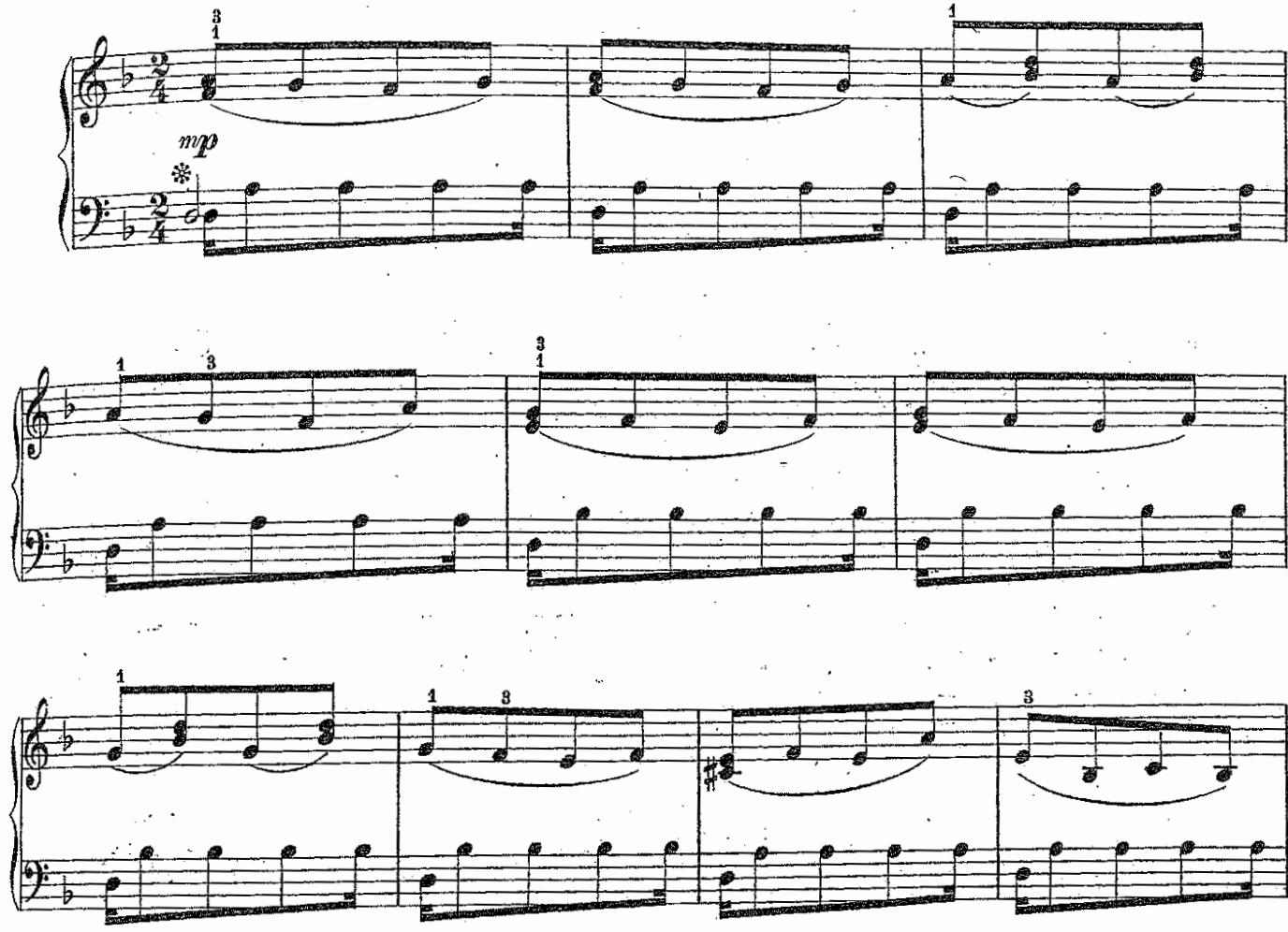

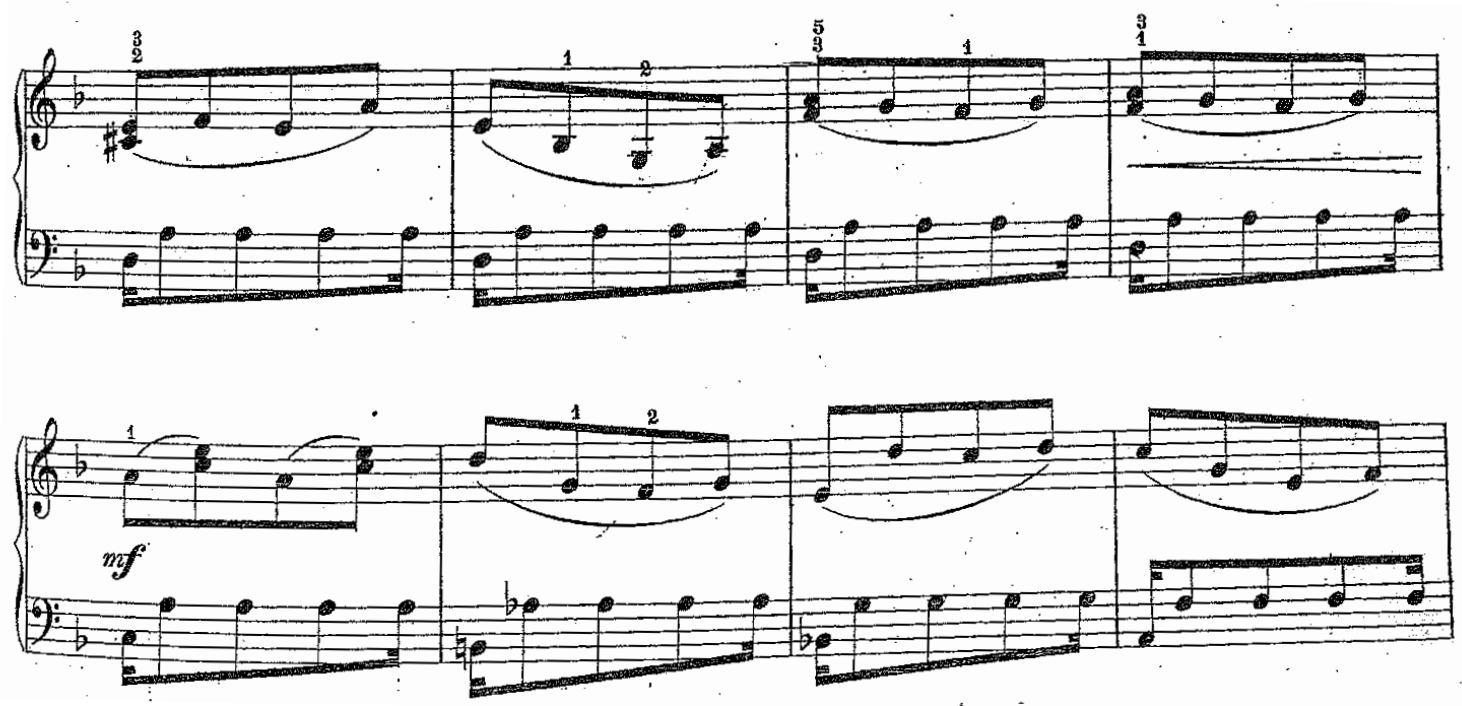

At the climax of the piece, the piano stops as Lang becomes overly distracted by the thought of the piece's theme. The score says, "Thinking of the soldiers fighting for us, she forgets to knit," and Lang quotes a church hymn, Onward Christian Soldiers, by Arthur Sullivan and inserted the refrain lyrics and tune, "Onward Christian soldiers, marching as to war," in the middle section of the piece (example 9.1.4c). Then this section closes with two eighth-note staccato figure resembling the beating of the heart (example 9.1.4c).

Example 9.1.4c Arthur Sullivan: Onward, Christian Soldiers, mm. 17-25
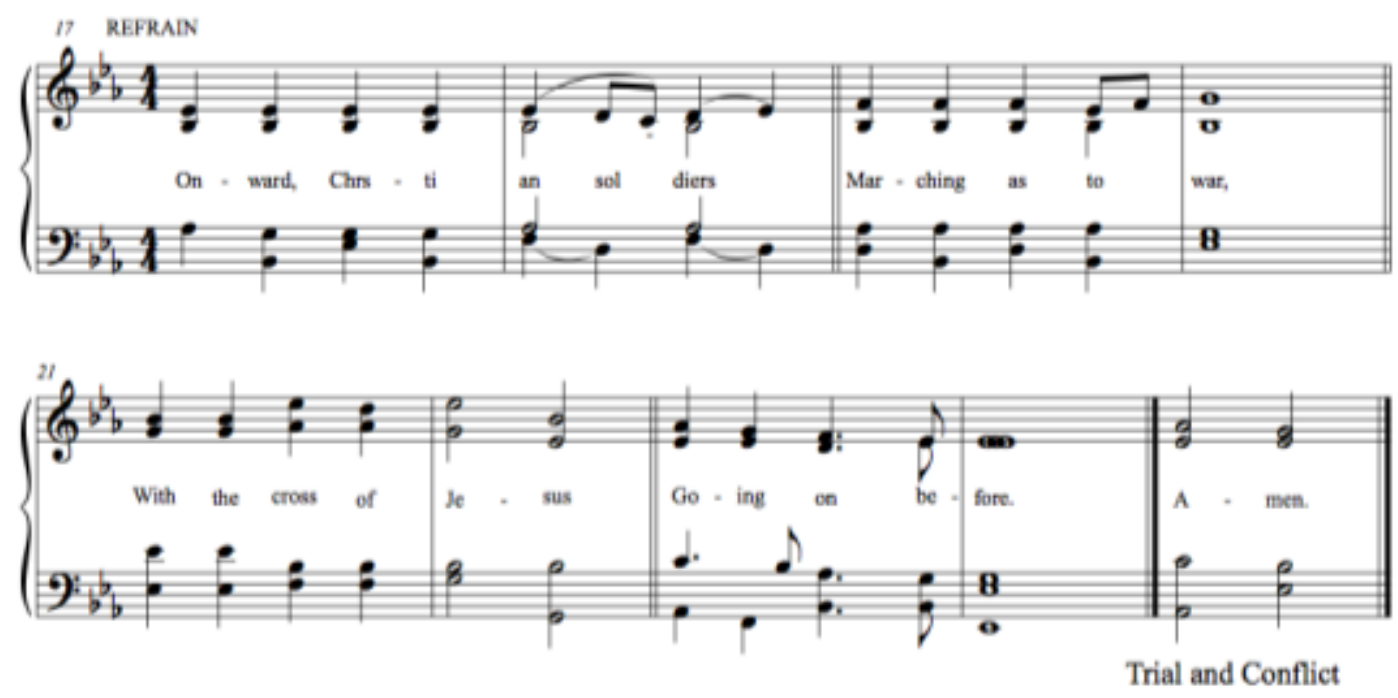

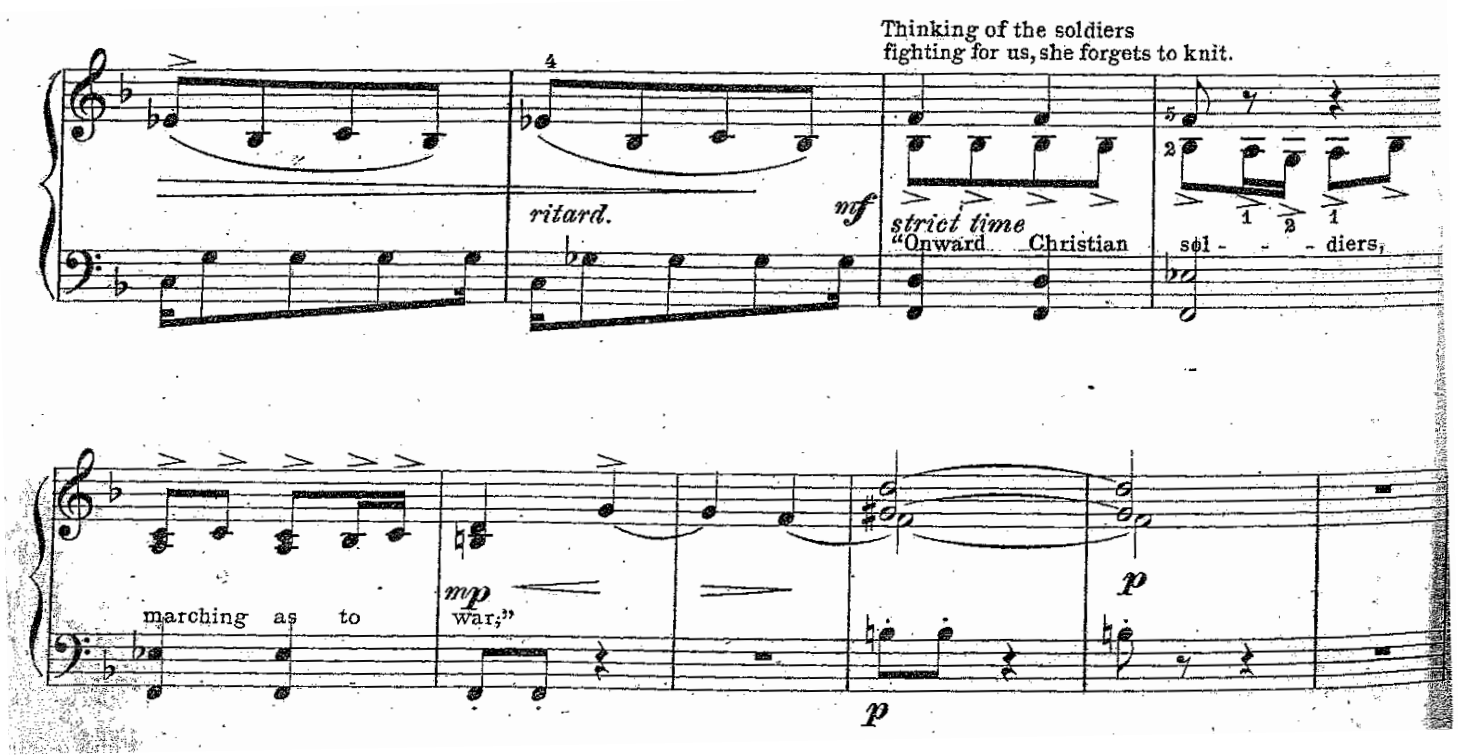

Next, Lang adds, "But then she remembers that the soldiers don't forget to fight for us." Then, only hesitatingly, the tune begins again as she realizes she has forgotten to keep knitting. This marks a recapitulation of the song that is written an octave higher than the opening (example 9.1.4f).

Example 9.1.4f Margaret Ruthven Lang: One Summer Day, op. 59 no. 4, mm. 41-49
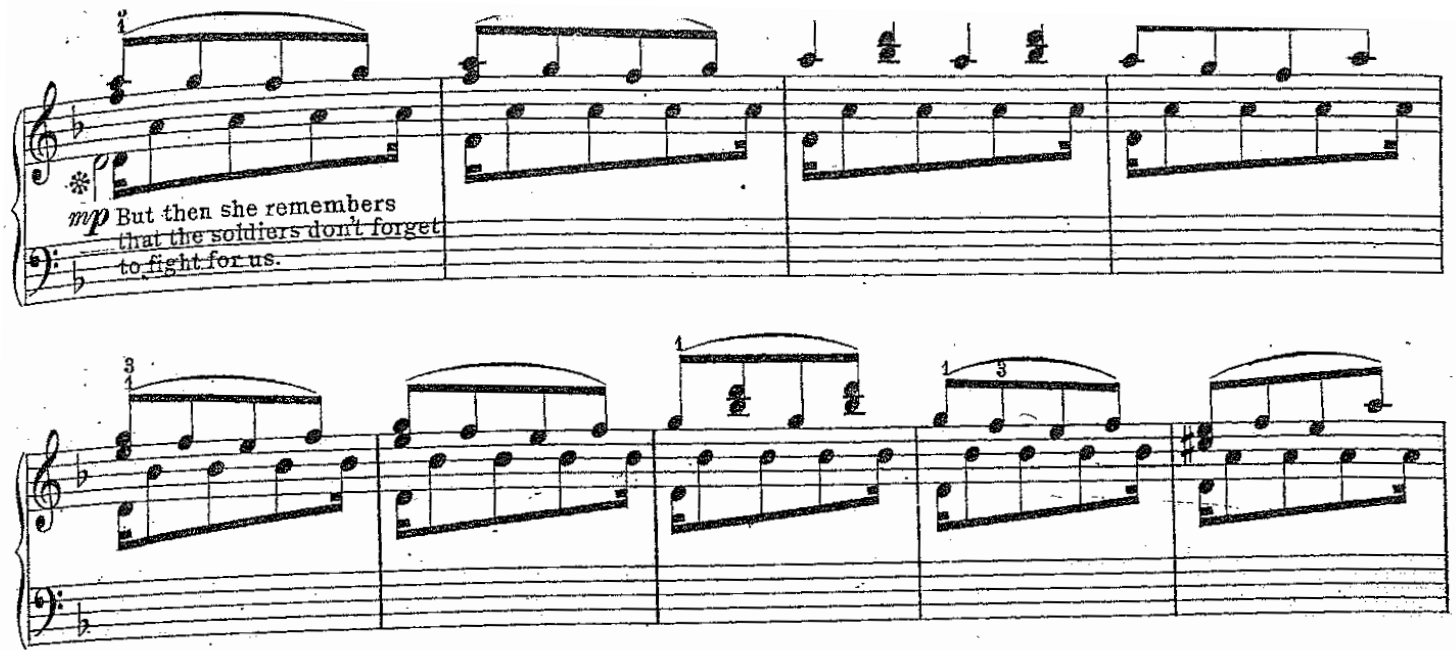

The piece is like a miniature toccata. It is excellent for students to develop precision in syncopated rhythm and evenness in attack. At the bottom of the first page, 
Lang writes, "If hands are large enough, lower sixteenth note should be held in the left hand throughout the piece as indicated in the first bar."

\section{Driving to the Blacksmith}

This song shows Lang's clever use of grace notes and harmonies to capture the "clip clop" of the horses' hooves. Lang uses a change of mode throughout, alternating between e minor and E Major, ultimately ending in the major. Again, Lang is very detailed in the expressive markings and offers students a fine work to develop not only imagination in realizing this scene, but also the technique of playing grace notes and creating a variety of sounds with the accents and dynamic changes throughout (example 9.1.5a).

Example 9.15a Margaret Ruthven Lang: One Summer Day, op. 59 no. 5, mm. 1-52

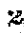

№ 16047. Driving to the Blacksmith

Allegro moderato M.M. $d=420$ Margaret Ruthven Lang
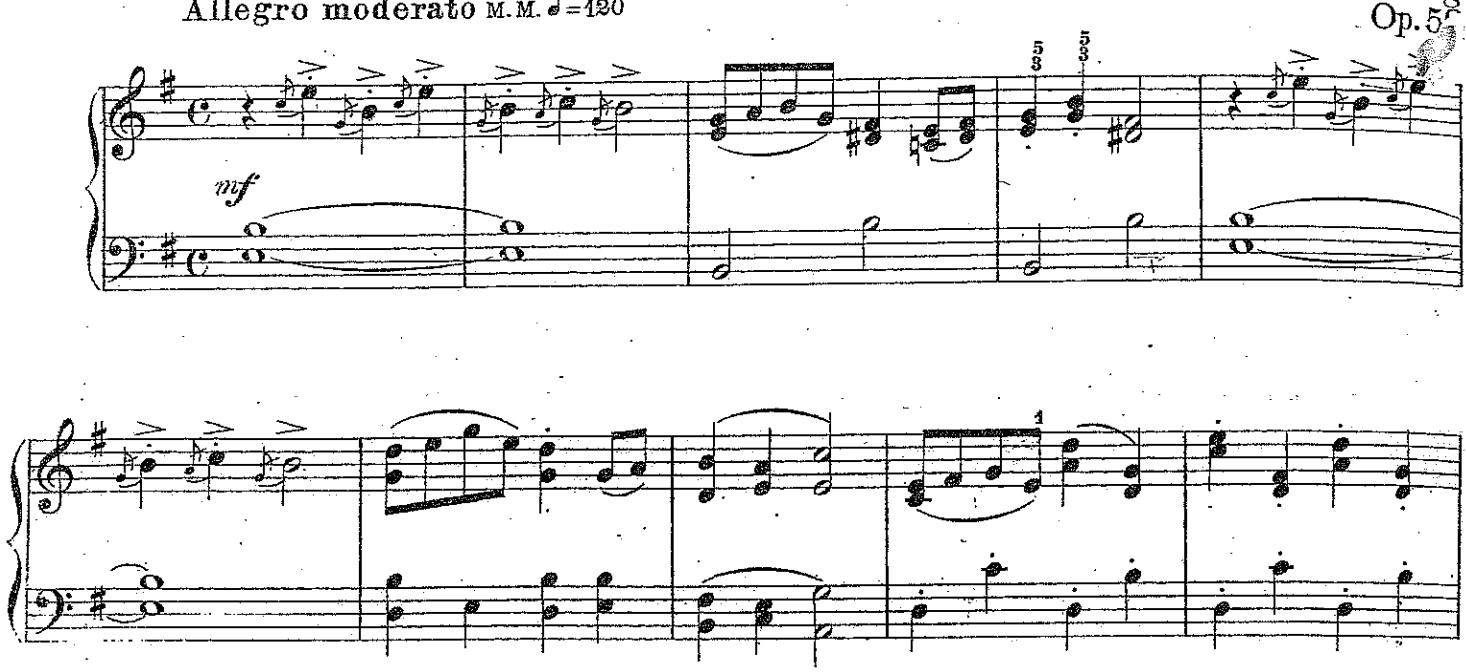

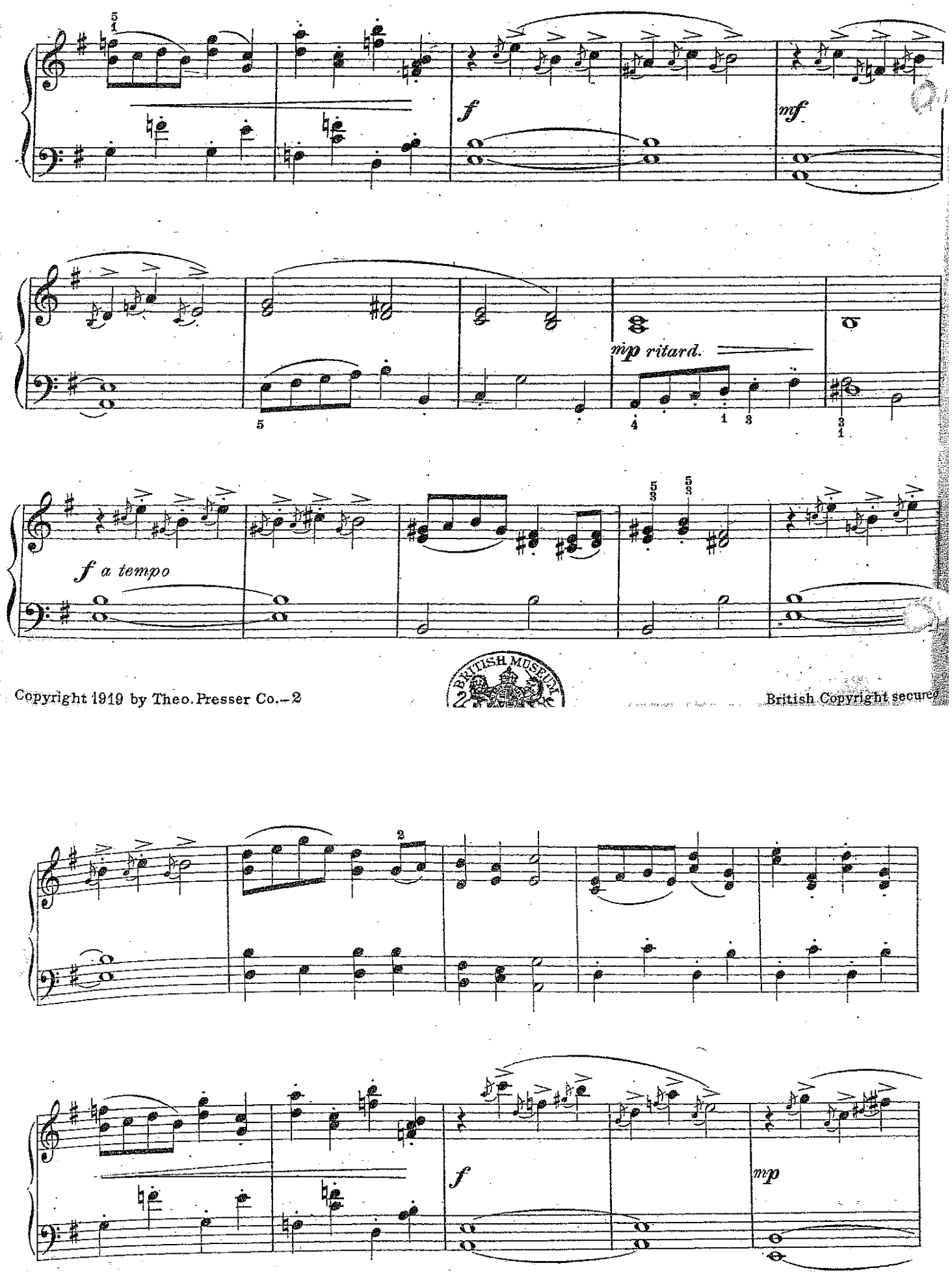

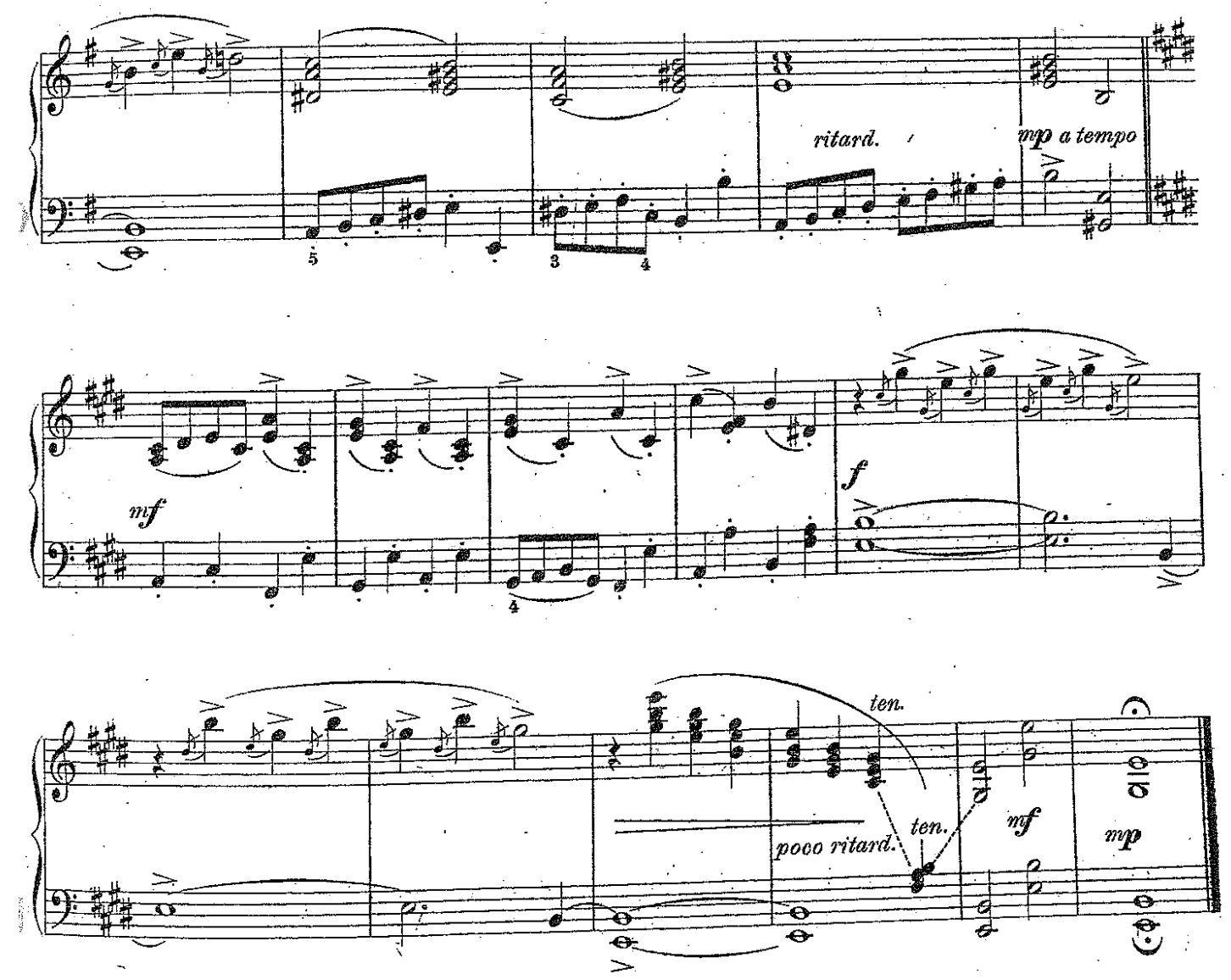

$-16047-8$ 


\section{THREE PIECES FOR YOUNG PLAYERS, OP. 60}

Three Pieces for Young Players, op. 60, as mentioned earlier, is Lang's final work. As the title suggests, this collection is suitable for students at the late elementary level, allowing them to engage with musical sophistication and attention to detail typically far beyond their years. The work is composed of three short pieces. They are marked Allegretto, Andantino, and Allegrettino, so there is no true slow movement, although the second presents a dreamy melody.

The fact that there is no thematic link between the pieces and there is no obvious cyclical aspect in the work makes it possible for the students to perform it as a set or play a single piece from it. Compared to One Summer Day, op. 59, this collection is simpler in terms of rhythm, articulation, texture, harmony, and voicing of the melody. There is no poetic insertion in this collection; however, one can easily imagine the scenes based on the titles and Lang's expressive markings.

\section{Happy Days}

Happy Days is an uplifting and joyous piece. It is written in G Major, and the tempo marking is Allegretto. On closer inspection, one may discover that this is a dance piece, a waltz. It is written in simple triple meter and has a charming melody combined with a traditional waltz-style accompaniment based on one harmony per measure. Lang chooses to place emphasis on the first beat of the bar and use the slur to give a dance-like lilt. Lang may have been inspired by Chopin's waltzes or even the Viennese waltz when she wrote this piece. She uses a rounded binary form here, with some charming variation at the return of A (example 9.2.1a) 
Example 9.2.1a Margaret Ruthven Lang: Three Pieces for Young Players, op. 60 no. 1, mm. 1-12

Allegretto M. M $=116$
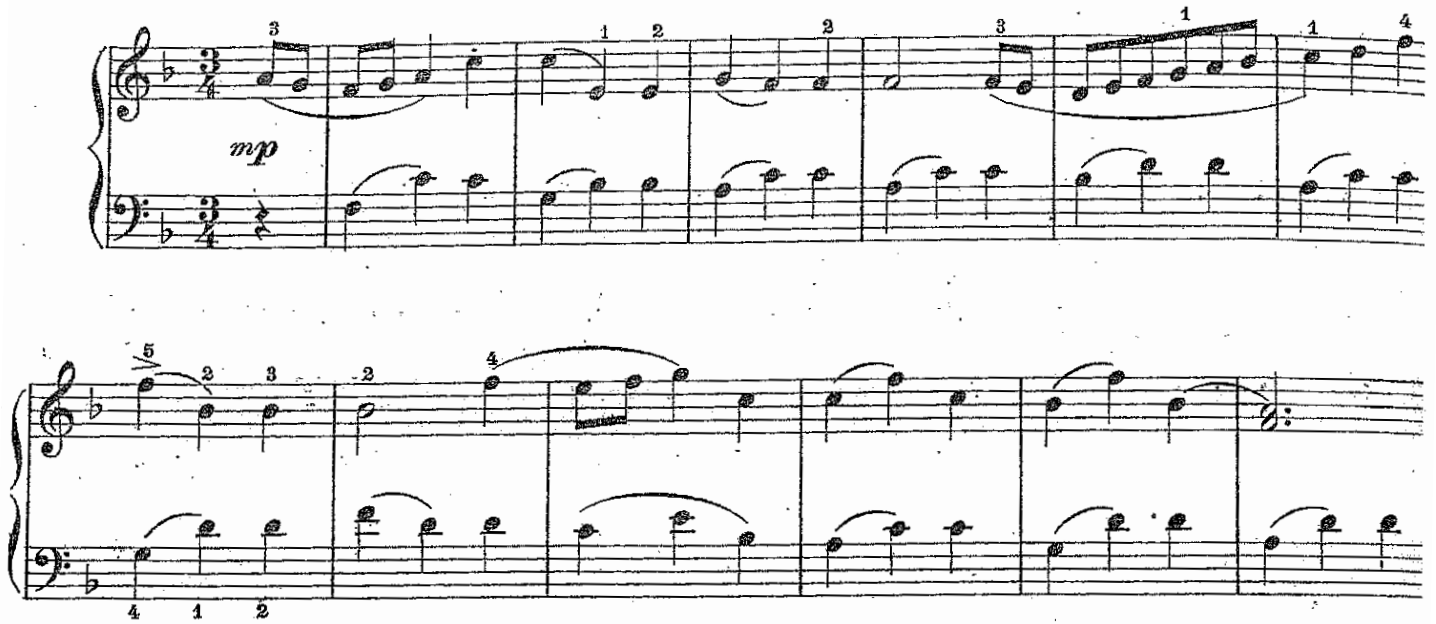

Lang marks espressivo at the beginning of the B section. She uses four bar phrases but with an interesting use of slurs that requires careful attention to delineate the shape and character of the melody (example 9.2.1b).

Example 9.2.1b Margaret Ruthven Lang: Three Pieces for Young Players, op. 60 no. 1, mm. 3350

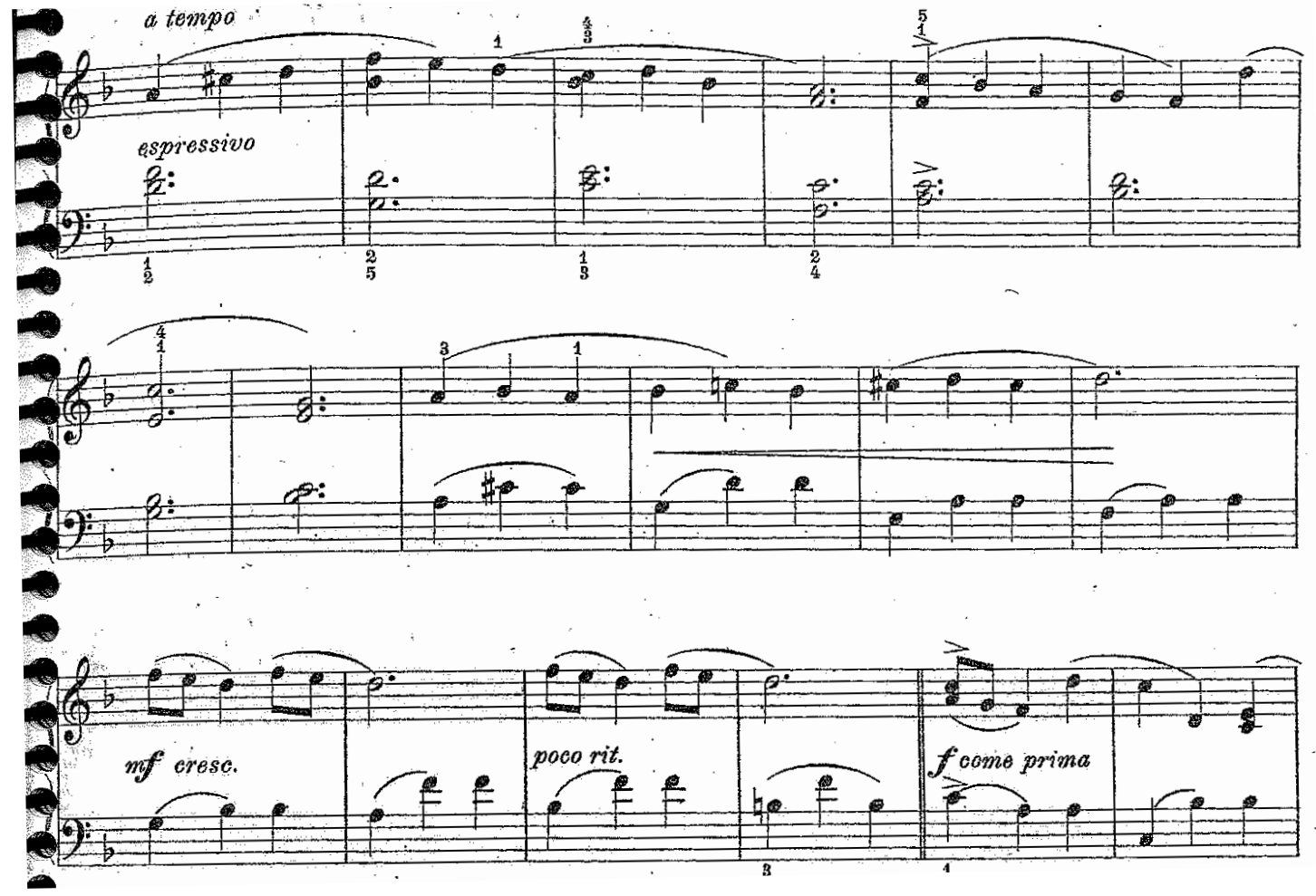


This piece requires much attention to the details of phrasing and slurs. Closer observation of the score reveals clearly that Lang's intention of this performance practice is implied by the specific slur marking into the second beat, sometimes followed by a staccato marking on beat three. Further challenges for the student are the left hand slurs which often are the opposite of the right hand, making this an excellent exercise in independence of the hands (example 9.2.1c).

Example 9.2.1c Margaret Ruthven Lang: Three Pieces for Young Players, op. 60 no. 1, mm. 1-6

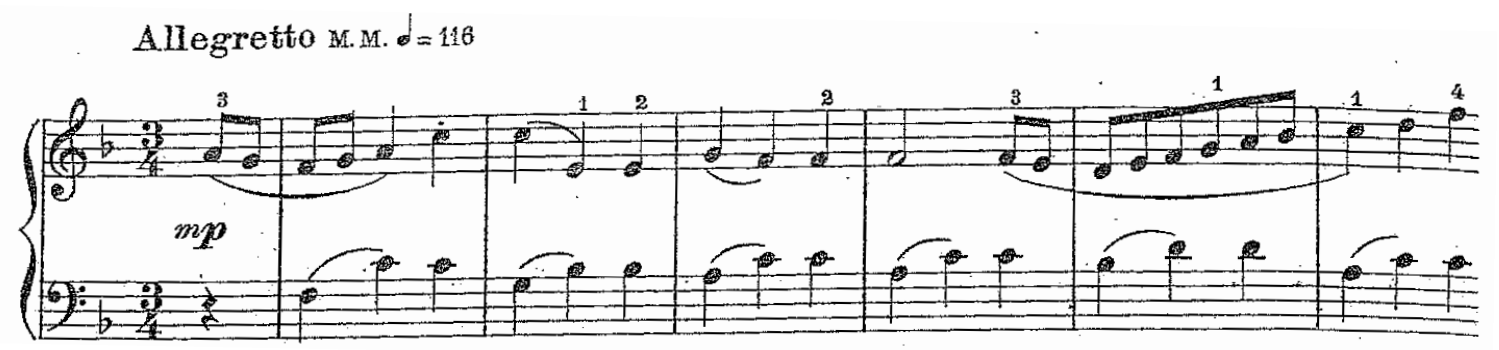

Example 9.2.1d Margaret Ruthven Lang: Three Pieces for Young Players, op.60 no. 1, mm. 20-25

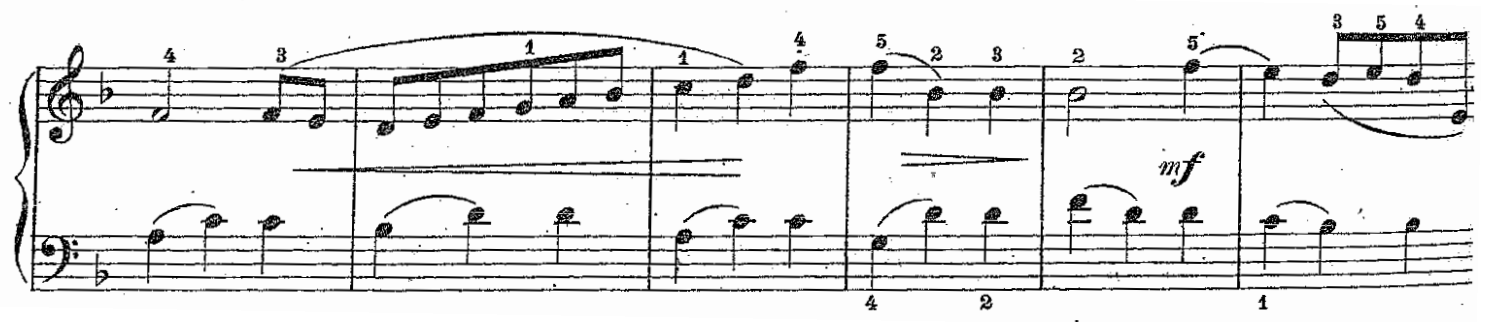

\section{Day-Dreams}

Lang uses a traditional ABA form here. She creates the pleasant day dreaming atmosphere with the major key, the Andantino tempo and the gentle dynamic range. The B section explores minor and unsettled harmonies before making its way back to the peaceful A section. Students will find the combination of left hand two-note slurs a challenge combined with the right hand's longer phrases (example 9.2.2a) 
Example 9.2.2a Margaret Ruthven Lang: Three Pieces for Young Players, op. 60 no. 2, mm. 1-6
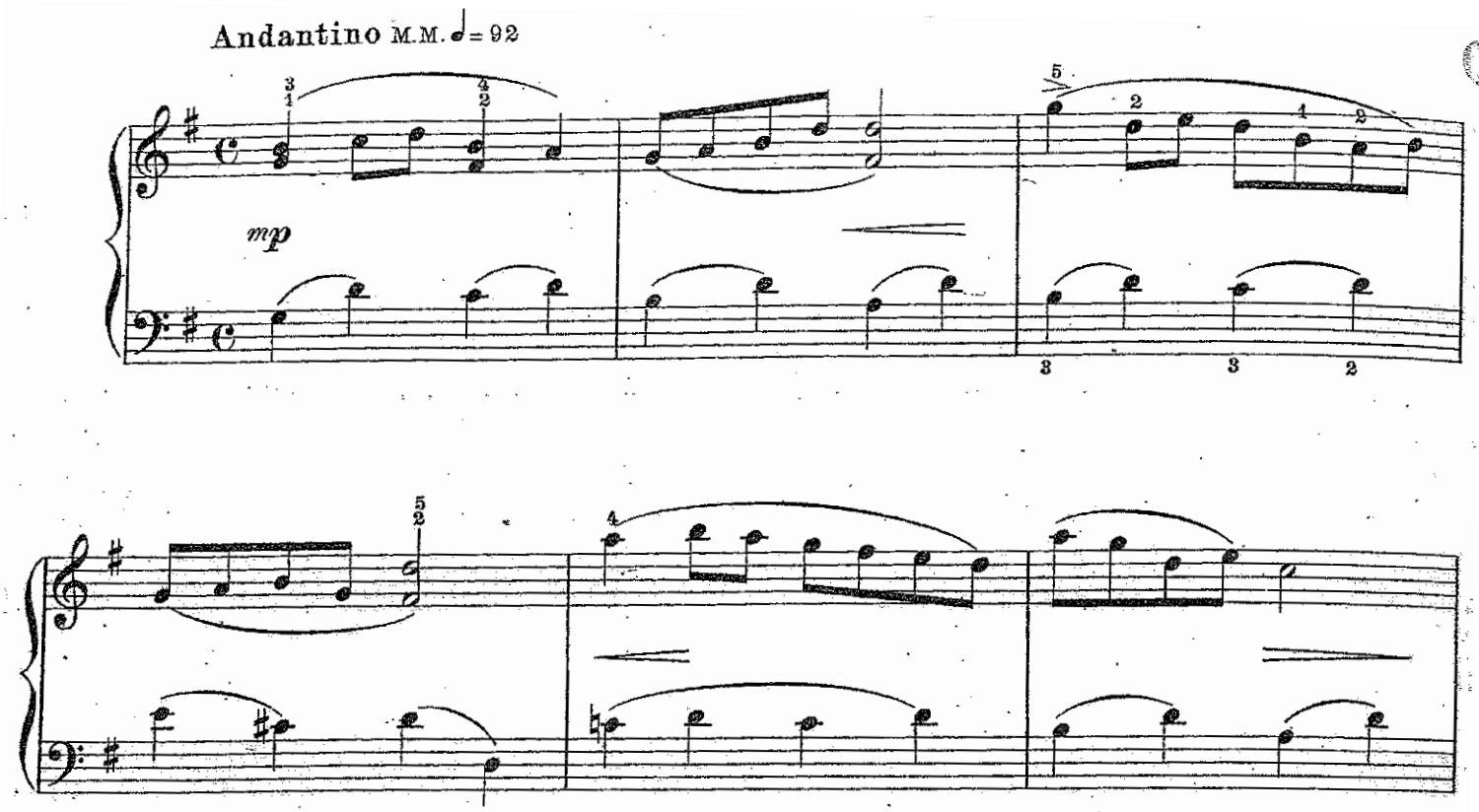

In the B section the left hand moves up to the treble register (example 9.2.2b).

Example 9.2.2b Margaret Ruthven Lang: Three Pieces for Young Players, op. 60 no. 2, mm. 1332

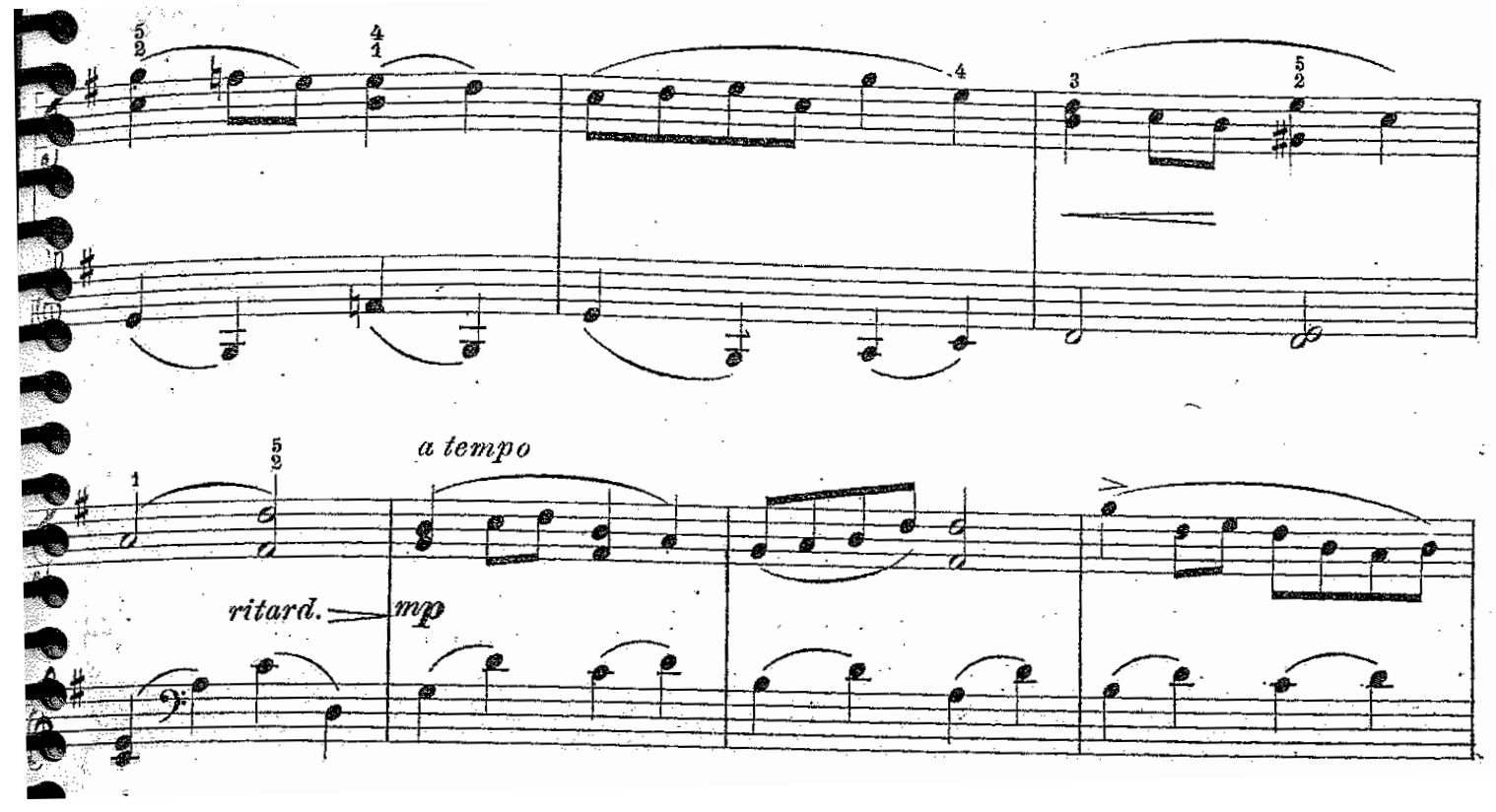




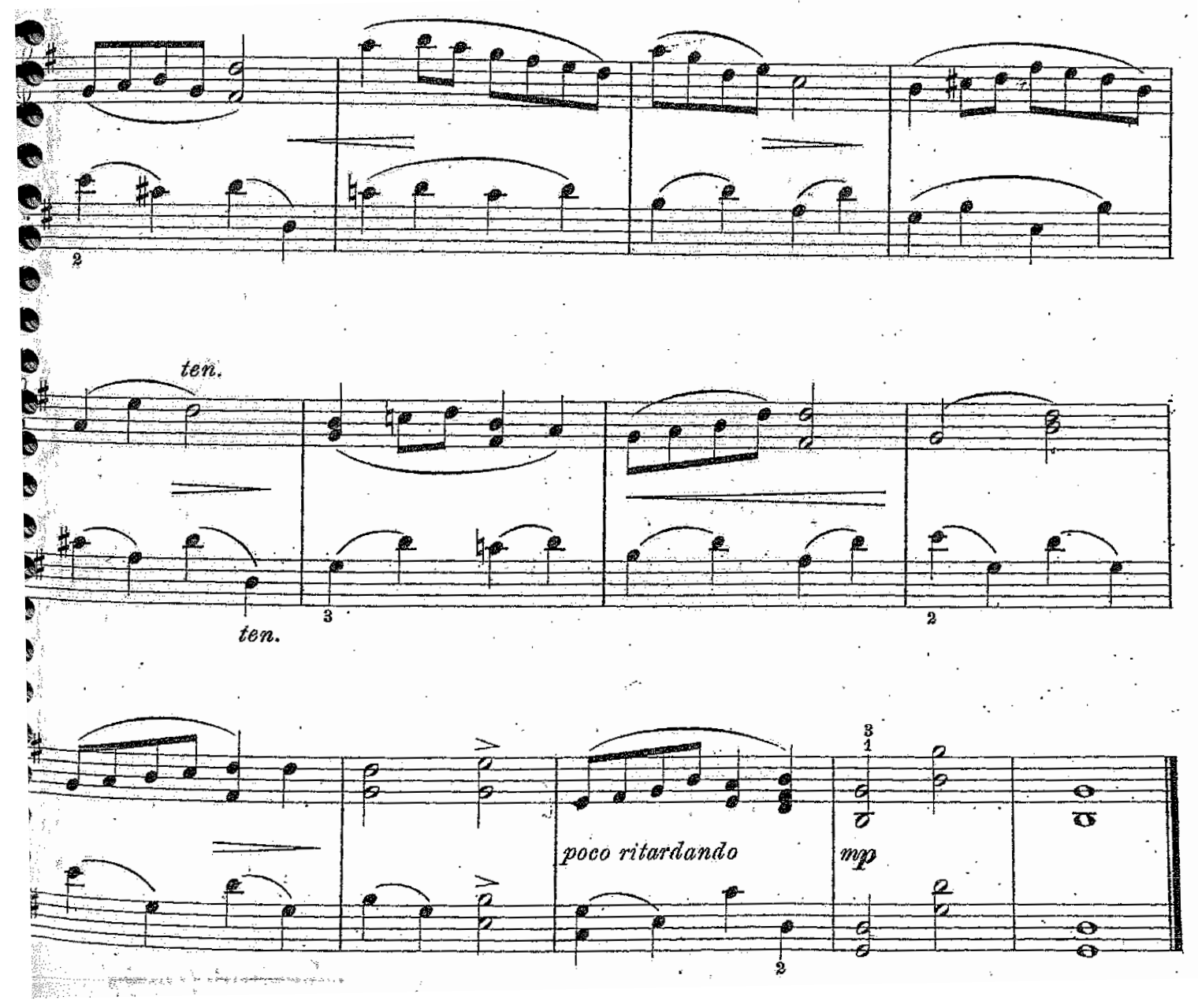

From the pedagogical aspect, it is challenging to play the left hand two-note slur, especially for the beginner, while the right hand is doing a full measure legato; the left hand two-note slur suggests the rhythmic movement of a clock while day-dreaming. Interestingly, Lang ends this piece with the same materials as she ends Driving to the Blacksmith (example 9.1.5a)

\section{Rondoletto}

The tempo marking is Allegrettino; Lang might have had something slower than Allegretto in mind when she wrote this music. (Allegrettino is not a traditional tempo marking; her metronome marking expresses a slower tempo than that of the first 
movement, Allegretto.) It is written in simple triple meter and has a charming melody with more sustained left-hand accompaniment.

Rondoletto is one of the two pieces by Lang that does not bear a descriptive title. Lang uses "rondoletto" to suggest a smaller scope than the rondo that is usually found in a sonata or concerto. As the title indicates, it is composed in a miniature ABACA form. It is a dance-like piece that opens with a buoyant four-measure theme in F Major in the right hand (example 9.2.3a).

Example 9.2.3a Margaret Ruthven Lang: Three Pieces for Young Players, op. 60 no. 3, mm. 1-5

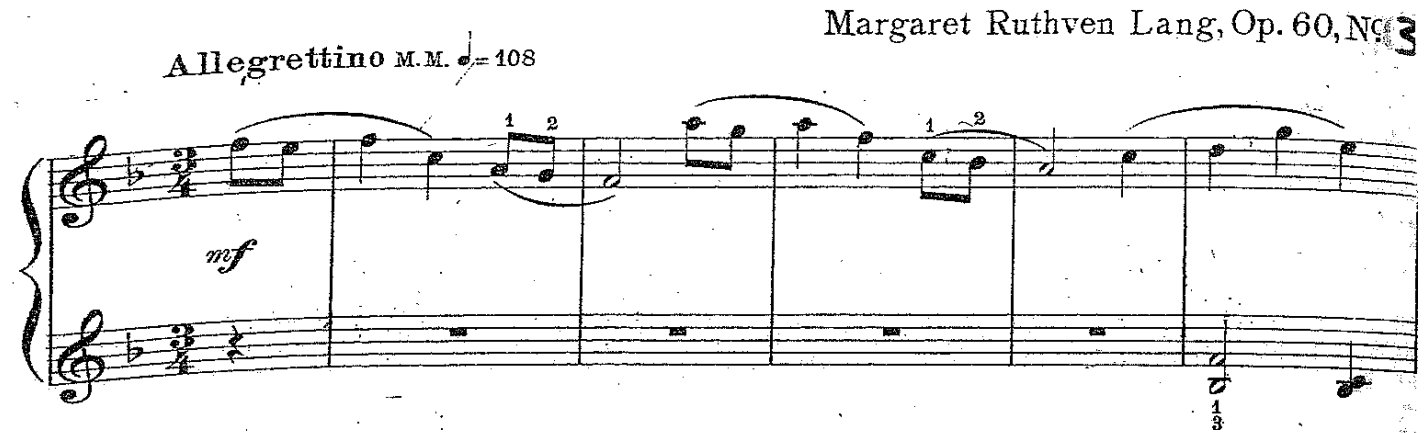

The B section continues the dance in the subdominant key (B-flat Major) and is marked espressivo (example 9.2.3b).

Example 9.2.3b Margaret Ruthven Lang: Three Pieces for Young Players, op. 60 no. 3, mm. 1322

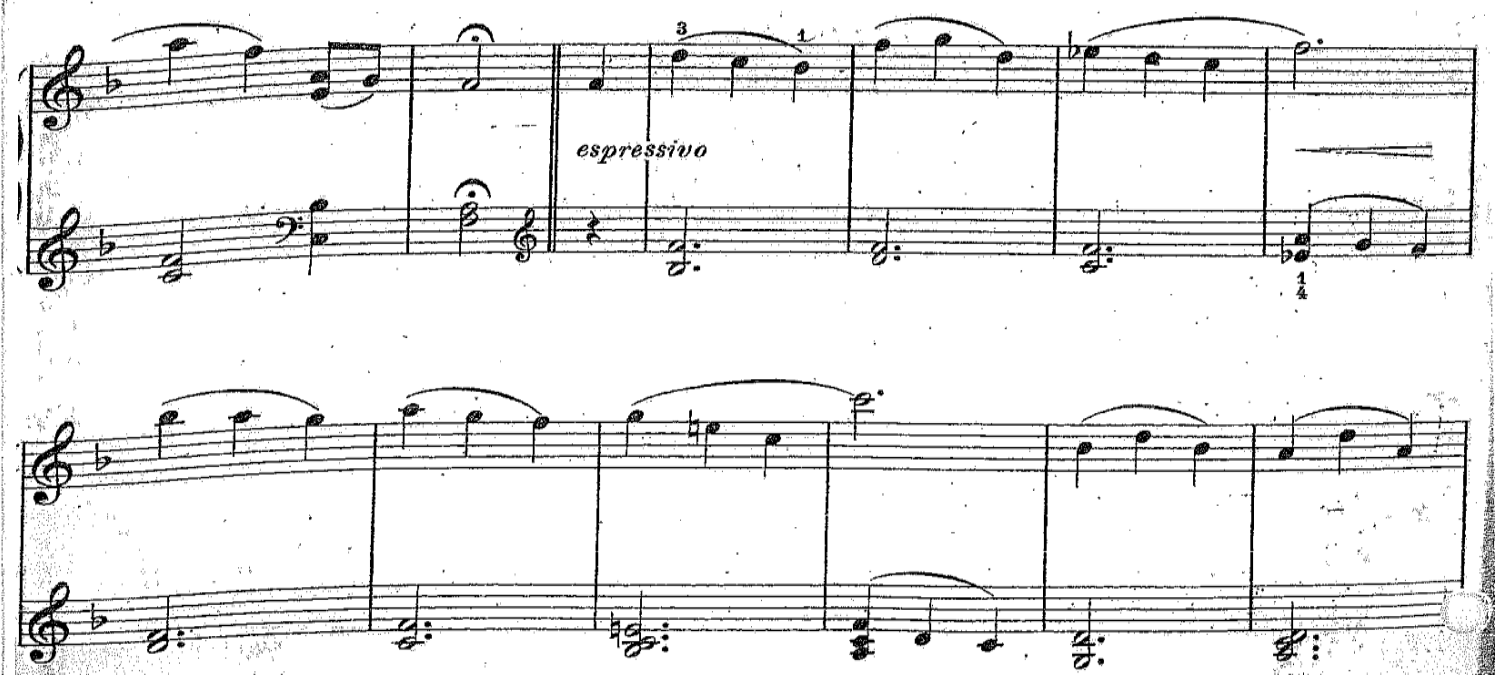


The $\mathrm{C}$ section is a cheerful tune that starts on the dominant seventh of the subdominant (example 9.2.3c).

Example 9.2.3c Margaret Ruthven Lang: Three Pieces for Young Players, op. 60 no. 3, mm. 2946

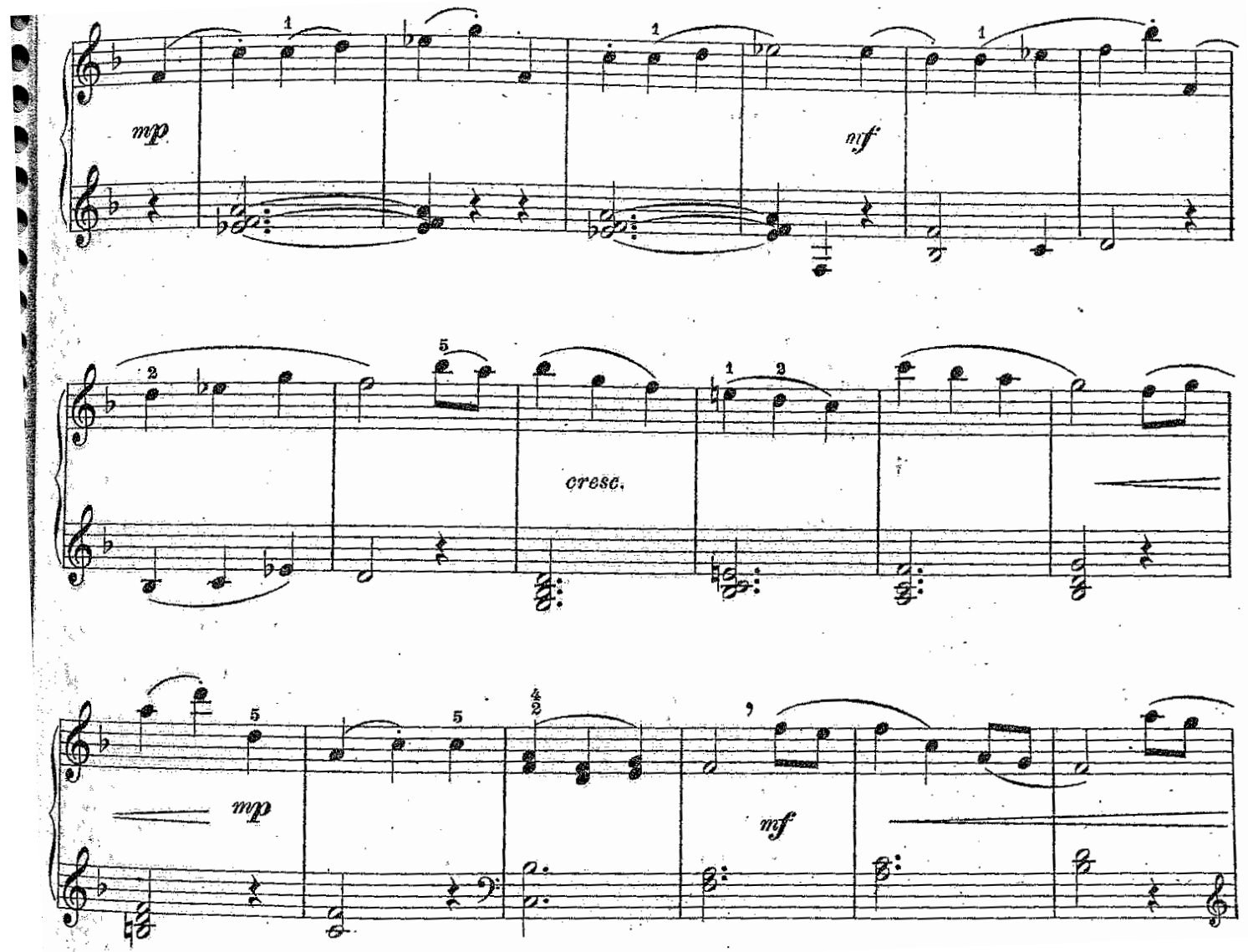

Interestingly, Lang uses this as a closing subject in the last two measures of the left hand and stresses the significance of this subject by ending this piece forte, using accents and a ritardando (example 9.2.3d). 
Example 9.2.3d Margaret Ruthven Lang: Three Pieces for Young Players, op. 60 no. 3, mm. 4752

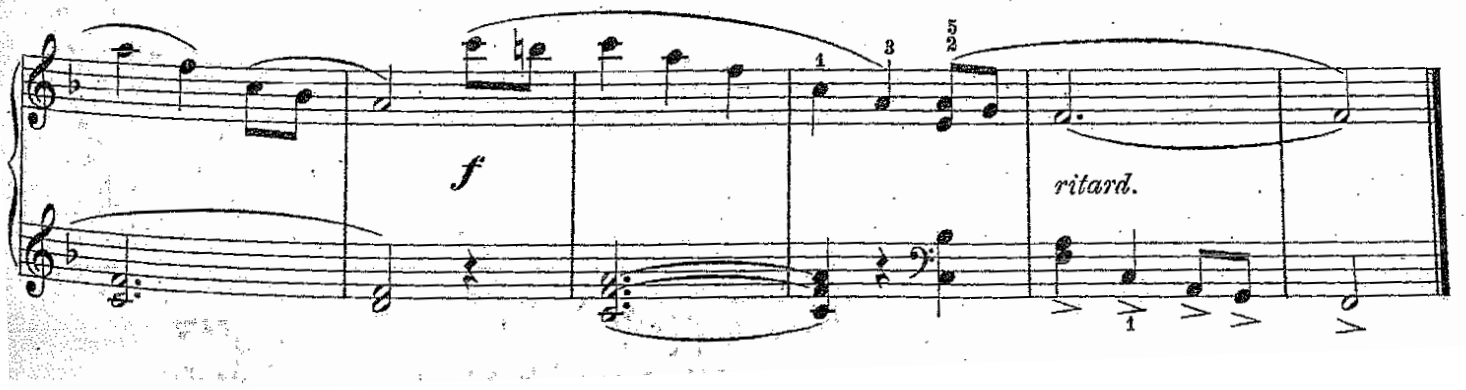

This piece is an enjoyable study for both hands playing in treble clef, focusing on articulation primarily in one hand, and developing skills in articulation. 


\section{CHAPTER X}

\section{CONCLUSION}

Musicians today have become increasingly interested in American music and particularly that of women composers. It is hoped that this research paper will be a useful tool for piano teachers and students to become more familiar with one of the most distinguished American women composers, Margaret Ruthven Lang.

Lang's piano music is an important source for musicians who are looking for repertoire by American composers. Living in one of the most up-to-date musical cities in America and growing up in a cosmopolitan household surrounded by famous musicians, Lang had musical experiences that were shaped and inspired by them. Her experiments with various musical styles are seen in her eleven published piano works; they cover a broad range of styles, yet she injected her own personal ideas.

In a sense, Lang's compositional style is like the American melting pot as she is able to successfully incorporate a variety of international styles and influences. Lang has a strong command of harmony and she is able to effectively capture diverse moods, styles, and feelings, from the charming French waltz of Bal chez Madame la Princesse from Petit Roman, to the Baroque influenced Rondoletto of Three Pieces for Young Players, and the German Romantic Rhapsody to the more American popular song like works such as Twilight and A Spring Idyl. Her piano pieces show the sophisticated musical life and education that she experienced also in their literary influence. Lang found inspiration from such diverse writers as Victor Hugo, John Vance Cheney, and Lizette Woodworth Reese and even included their poetry on several of the published piano scores. Her own writings also found expression in her piano music with the 
imaginative Petit Roman, an extended work of six movements based on a tragic love story which she wrote in French. All of these influences inspired Lang to experiment with harmony, texture and melody and to create each piece in its own unique musical style.

From a pedagogical perspective, Lang's piano music ranges from late elementary through advanced difficulty level. These works make excellent pieces for study and performance in the private studio as well as at the college level. In addition, each of her works can be viewed as an etude that combines technical challenges and descriptive musical substance: for example, Starlight, in which the left hand is trying to achieve the subtleties of the barcarolle while the right hand is depicting the Starlight through consecutive thirds and sixths. Lang's meticulous attention to details of expression further makes her works particularly appealing for developing a variety of technical and interpretive skills.

Lang was a significant composer during her time as evidenced by the numerous performances of her works and the publication of them. Her music was performed regionally, nationally and internationally and there is record of numerous performances of her piano works in New England and New York.

The piano music of Margaret Ruthven Lang is indeed an important contribution to the canon of piano literature, both in its musical substance and historical interest. 


\section{APPENDIX}

\section{CHRONOLOGICAL LISTS OF PIANO WORKS}

\begin{tabular}{|c|c|c|c|}
\hline Opus Number & Title & Publisher & $\begin{array}{l}\text { Publication } \\
\text { Date }\end{array}$ \\
\hline $\mathrm{WoO}$ & $\begin{array}{l}\text { Starlight ("Half Hours with the } \\
\text { Best Composers," part 10), pp. } \\
478-482\end{array}$ & J. B. Millet. & 1894 \\
\hline WoO & $\begin{array}{l}\text { Twilight ("Half Hours with the Best } \\
\text { Composers," part 10), pp. } 473-477\end{array}$ & J. B. Millet. & 1894 \\
\hline Op. 18 & $\begin{array}{l}\text { Petit Roman en six chapitres } \\
\text { 1. Le Chevalier. } \\
\text { 2. Madame la Princesse. } \\
\text { 3. Bal chez Madame la Princesse. } \\
\text { 4. Monsieur le Prince. } \\
\text { 5. L'Épée de Monsieur le Prince. } \\
\text { 6. La Mort du Chevalier. }\end{array}$ & $\begin{array}{l}\text { A.P. Schmidt } \\
\text { Hildegard } \\
\text { Publishing } \\
\text { Company }\end{array}$ & $\begin{array}{l}1894 \\
2000\end{array}$ \\
\hline Op. 21 & Rhapsody in e minor & $\begin{array}{l}\text { A.P. Schmidt } \\
\text { Hildegard } \\
\text { Publishing } \\
\text { Company }\end{array}$ & $\begin{array}{l}1895 \\
1990\end{array}$ \\
\hline Op. 26 & Meditation & A.P. Schmidt & 1897 \\
\hline Op. 30 & $\begin{array}{l}\text { Springtime } \\
\text { "The World's Best Composers" } \\
\text { vol. } 4 \text {, pp. } 967-970 .\end{array}$ & $\begin{array}{l}\text { G.J. Bryan } \\
\text { New York } \\
\text { University } \\
\text { Society }\end{array}$ & $\begin{array}{l}1899 \\
1899\end{array}$ \\
\hline Op. 31 & Revery & $\begin{array}{l}\text { John Church } \\
\text { Co. }\end{array}$ & 1899 \\
\hline Op. 33 & Spring Idyl & $\begin{array}{l}\text { John Church } \\
\text { Co. }\end{array}$ & 1899 \\
\hline Op. 58 & The Spirit of the Old House & A.P. Schmidt & 1917 \\
\hline
\end{tabular}


Op. 59

One Summer Day

Theodore

1919

1. Hide and Seek in the Barn

Presser

2. Morning Lessons

3. Picnic in the Woods

4. Knitting for the Soldiers

5. Driving to the Blacksmith

Op. 60

Three Pieces for Young Players

Theodore

1919

1. Happy Days

Presser

2. Day Dreams

3. Rondoletto 


\section{BIBLIOGRAPHY}

Adams, Juliette A. Graves. “Musical Creative Work Among Women,” Music (1896), $265-72$.

Ammer, Christine. Unsung: A History of Women in American Music. Portland, OR: Amadeus Press, 2001.

Barnes, Edwin Ninyon Chaloner. American Women in Creative Music. Washington D.C.: Music Education Publications, 1936.

Blunsom, Laurie. "Gender, Genre and Professionalism: The songs of Clara Rogers, Helen Hopekirk, Amy Beach, Margaret Lang and Mabel Daniels, 1880-1925." Ph.D.diss., Brandeis University, 1999.

Cavalli, Harriet. Dance and Music: A Guide to Dance Accompaniment for Musicians and Dance Teachers. Florida: University Press, 2001.

Cline, Judith Ann. "Margaret Ruthven Lang: Her Life and Songs." Ph.D. diss., Washington University, 1993.

Cline, Judith Ann. "Margaret Ruthven Lang." In Women Composers: Music Through the Ages, vol. 7, edited by Sylvia Glickman and Martha Furman Schleifer. New York: G. K. Hall, 2003.

Duggan, Thomas, “John Bannister Tabb," The Catholic Encyclopedia, vol. 14 (New York: Robert Appleton Company, 1912). http://www.newadvent.org/cathen/14423c.htm (accessed February 23, 2013).

Feldman, Ann E. "Being Heard: Women Composers and Patrons at the 1893 World's Columbian Exposition." Notes, Second Series 47, no. 1 (Sept, 1990): 7-20. http://www.jstor.org/stable/940531 (accessed Oct 29, 2012).

George, Donald and Lucy Mauro. "Margaret Ruthven Lang (1867-1972) and Her German Roots in the Wagnerian Circle," Die Tonkunst 2 (2012), 213.

George, Donald and Lucy Mauro, "Margaret Ruthven Lang: On the 40th Anniversary of Her Death," http://hampsongfoundation.org/margaret-ruthven-lang-on-the-40thanniversary-of-her-death/ (accessed February 12, 2013).

George, Donald and Lucy Mauro. "Retreat from Fame: Margaret Ruthven Lang, the once famous Boston composer, rediscovered." The Bulletin of the Society For American Music 37 (2011), 33-4. 
Glickman, Sylvia. American Woman Composers: Piano Music from 1865-1915 (Bryn Mawr: Hildegard Publishing Company, 1990), 3.

Gordon, Stewart. A History of Keyboard Literature: Music for the Piano and Its Forerunners New York: Schirmer Books, 1996, 358.

Glickman, Sylvia and Martha Furman Schleifer. From Convent to Concert Hall: A Guide to Women Composer. Westport, CT: Greenwood Publishing Group, Inc., 2003.

Herbert, Victor. The World's Best Composers, IV (New York: New York University Society, 1899), 967-970.

Hughes, Rupert. Contemporary American Composers. Boston: L.C. Page and Co., 1900.

Johnston, James. Margaret Ruthven Lang \& Family, "Margaret Ruthven Lang 18671972” http://www.margaretruthvenlang.com (accessed January 29, 2013).

Mathews, William Smythe Babcock . The Great in Music: A Systematic Course of Study in the Music of Classical and Modern Composers, 1. Chicago: Music Magazine Publishing Company, 1900, 277-82.

Miller, Margo. "Oldest B.S.O. Subscriber Recalls Gentle World of the Past-Life With Liszt and the Wagners," Boston Globe, February 19, 1967, p. A-27.

Mullins, John J. “Composer Margaret Lang, 101, Just 'Wants to Live Forever."” Boston Globe, 19 February 1967 as quoted in Johnston

New World Encyclopedia contributors, "Victor Hugo," New World Encyclopedia, http://www.newworldencyclopedia.org/p/index.php?title=Victor_Hugo\&oldid=79 4680 (accessed February 18, 2013).

Rogers, Clara Kathleen. The Story of Two Lives: Home, Friends and Travels. Massachusetts: Plimpton Press, 1932.

Saerchinger, César. International Who's Who in Music and Musical Gazetteer. New York: Current Literature Publishing Company, 1918.

Quoted in “John B. Tabb," http://www.poetry-archive.com/t/tabb_john_banister.html (accessed February 23, 2013) from Jessie B. Rittenhouse, The Little Book of American Poets: 1787-1900 (Cambridge: Riverside Press, 1915).

Quoted in Margaret Ruthven Lang \& Family, "Bibliography" http://www.margaretruthvenlang.com (accessed January 29, 2013), "Boston Music Notes - Margaret Ruthven Lang,” Musical Courier, January 1895. 
Quoted in Cline, Judith Ann. "Margaret Ruthven Lang: Her Life and Songs." Ph.D. diss., Washington University, 1993. "Lang Family Papers, scrapbooks; Lang Family Papers, Boston Public Library."

Theodore Presser Company, "The Presser Story,” About Us, http://www.presser.com/aboutus.cfm (accessed February 21, 2013).

Tick, Judith. "Women as Professional Musicians in the United States, 18701900."Anuario Interamericano de Investigacion Musical 9, (1973): 95-133. http://www.jstor.org/stable/779908. (accessed 29 Oct, 2012).

Wagner, Cosima. Diaries, ed. by Martin Gregor-Dellin and Dietrich Mack, trans. by Geoffrey Skelton, Volume I - 1869-1877. New York: Harcourt Brace Jovanovich, 1978 . 